Luciano Freschi

Sinalização hormonal e do óxido nítrico na indução do metabolismo ácido crassuláceo em Ananas comosus

São Paulo 2008 


\section{Luciano Freschi}

\section{Sinalização hormonal e do óxido nítrico na indução do metabolismo ácido crassuláceo em}

Ananas comosus

Tese apresentada ao Instituto de Biociências da Universidade de São Paulo, para a obtenção de Título de Doutor em Ciências, na Área de Botânica.

Orientadora: Profa. Dra. Helenice Mercier

São Paulo 


\section{Ficha Catalográfica}

Freschi, Luciano

Sinalização hormonal e do óxido nítrico na indução do metabolismo ácido crassuláceo em Ananas comosus.

Número de páginas: $143 \mathrm{p}$.

Tese (Doutorado) - Instituto de Biociências da

Universidade de São Paulo. Departamento de Botânica.

1. Metabolismo ácido crassuláceo 2. Hormônios vegetais 3. Óxido nítrico I. Universidade de São Paulo. Instituto de Biociências. Departamento de Botânica.

Comissão Julgadora:

$\operatorname{Prof}(a) . \operatorname{Dr}(a)$.

$\overline{\operatorname{Prof}(a)} \overline{\operatorname{Dr}(a)}$

Prof(a). Dr(a).

Prof(a). Dr(a).

Profa. Dra. Helenice Mercier

Orientadora 
"No fundo, só se sabe que sabemos pouco; com o saber cresce a dúvida."

Johann Wolfgang von Goethe 
Aos meus pais, irmãos e sobrinhos pelo carinho, apoio e perseverança.

À Auri, pelo companheirismo, incentivo e amor.

Dedico. 


\section{AGRADECIMENTOS}

À Profa. Dra. Helenice Mercier, pela orientação, confiança, ensinamentos e oportunidades oferecidas. Obrigado pela dedicação, incentivo e amizade durante todos esses anos de convívio.

Ao Prof. Dr. Gilberto Barbante Kerbauy, pelos valiosos conselhos, apoio, amizade e, acima de tudo, pelo exemplo de dedicação, competência e profissionalismo.

À Profa. Dra. Marie-Anne Van Sluys, pela orientação referente à parte de biologia molecular, discussão dos resultados, e também pela amizade e entusiasmo sempre presentes.

Ao Prof. Dr. Eduardo Purgatto (Faculdade de Ciências Farmacêuticas - USP), pela colaboração nas dosagens de AIA e ABA, pelos ensinamentos, sugestões e ajuda em várias fases do trabalho.

Ao Prof. Dr. José Ronaldo Magalhães (EMBRAPA, Juiz de Fora, MG), pelos conselhos, oportunidades, apoio, e, sobretudo, pela amizade e confiança cultivadas durante esse período.

Ao Dr. Werner W. Kaiser (Universidade de Würzburg, Alemanha), pelos ensinamentos técnicos e teóricos, pelas sugestões sempre oportunas e, também, pelo entusiasmo e profissionalismo.

À Auri, pelo amor, dedicação, companheirismo, por me ajudar nas horas de estresse, e por tanta coisa que deixo de escrever por motivos de espaço. Divido essa tese com você.

À Camila e Cássia pela alegria e ajuda deste o início deste trabalho.

À Thais, Lia, Aline Bertinatto, Alessandra, Cíntia, Ilton, Aline Cavalari, Patrícia Pinho, Giovanna, pela amizade, apoio e por tornarem o ambiente de trabalho um local agradável e divertido.

À todos os demais colegas do Laboratório de Fisiologia Vegetal (LFV) do IBUSP: Adriana Grandis, Adriana Yepes, Amanda, Bruna, Flavia, Ivan, Leila, Luis, Laura, Maraba, Marcelo, Mari, Paulo, Priscila. Agradeço pela paciência, alegria e ajuda em todos os momentos. Obrigado pelas discussões de cunho científico e pelos momentos de descontração.

À todos os ex-membros do LFV: Adélia, Bia Maia, Catarina, Kátia Campos, Regina, Rosete, Rogério, Vagner e Vívian, pelo convívio agradável e apoio durante o início deste trabalho.

Às técnicas Ana Maria e Ingrid, pelo apoio, paciência e constante disponibilidade em ajudar. 
Aos colegas do Laboratório de Biologia Molecular de Plantas do IBUSP: Alessandro, Ana Paula Costa, Breno, Bruno, Dani K, Dani Milstein, Edgar, Erika, Guilherme, Hana, Jonas, Juliane, Leonor, Luiza, Vivian, Marcelo, Maria Elisa, Marisa, Myna, Nilo, Regina, Silvia, Úrsula. Pelo auxílio em várias situações, pelos ensinamentos e pelo convívio amigável.

Gostaria de agradecer em especial ao Douglas, pela paciência, dedicação e profissionalismo com que me supervisionou durante a realização das análises de biologia molecular deste trabalho. Agradeço também à Profa. Dra. Maria Magdalena Rossi pelas sugestões, ensinamentos e apoio.

À todas as pessoas do Laboratório de Anatomia Vegetal, IBUSP, em especial a Gisele pelo apoio técnico e ao Prof. Dr. Gregório Cecantini pelos ensinamentos e disponibilização do microscópio de fluorescência.

À Linácea e Suzy pela paciência, alegria e disposição em ajudar.

Aos secretários do Departamento de Botânica, Norberto, Carlos e Cesário pelo atendimento e esclarecimentos prestados.

Aos secretários da Seção de Pós-graduação, Helder, Érika e Vera, pelo auxílio nos processos burocráticos.

À todos que contribuíram de alguma forma para a realização deste trabalho.

À Fundação de Amparo à Pesquisa do Estado de São Paulo (FAPESP) pelo apoio financeiro. 


\section{ÍNDICE GERAL}

Lista de abreviaturas

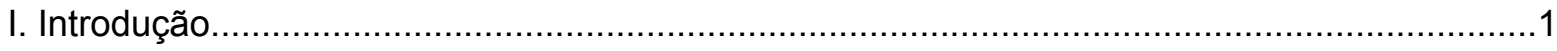

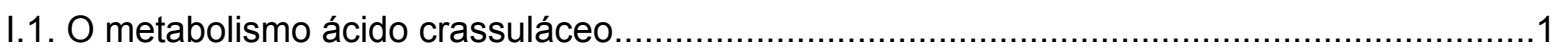

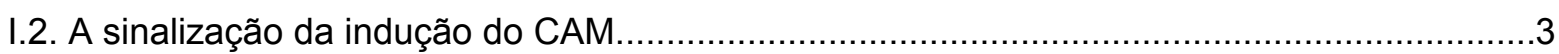

I.3. O abacaxizeiro como modelo para estudos da sinalização da expressão do CAM..............14

II. Objetivos.

III. Material e Métodos. .19

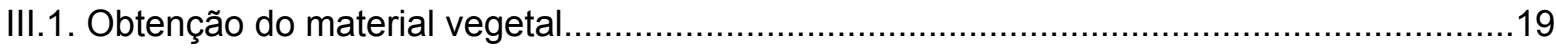

III.2. Tratamentos para indução e reversão do CAM em abacaxizeiro........................................20

III.3. Tratamentos para análise da influência de hormônios, cálcio citossólico e óxido nítrico

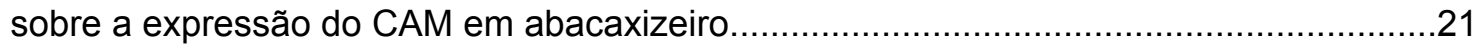

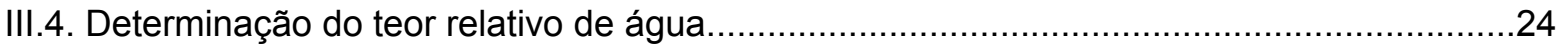

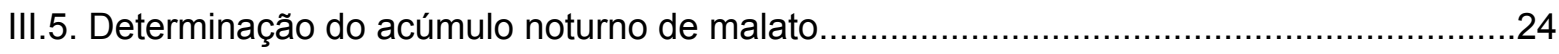

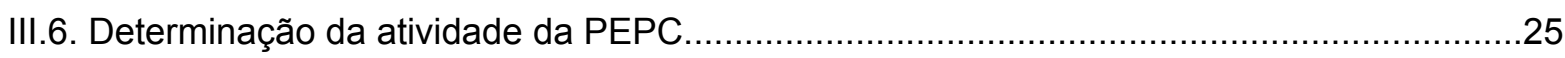

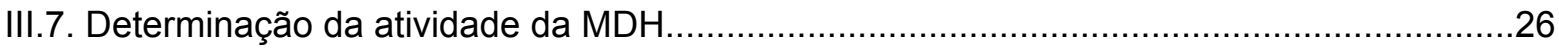

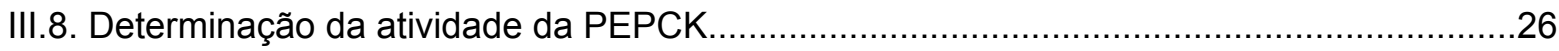

III.9. Quantificação dos teores endógenos de citocininas, AIA e ABA .....................................27

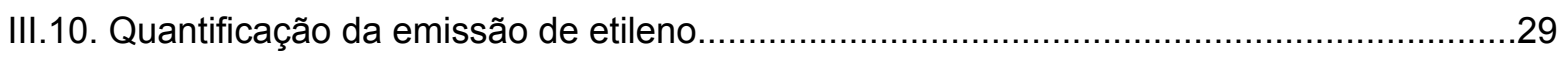

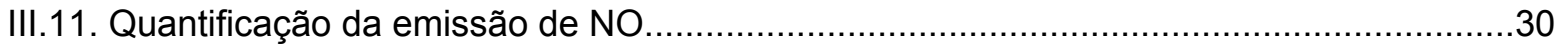

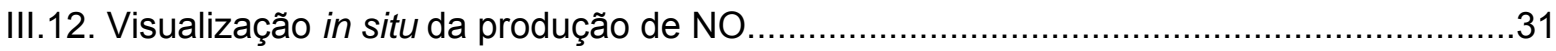

III.13. Amplificação, clonagem e seqüenciamento da PEPC, MDH e PEPCK de A. comosus....32

III.14. Análises dos teores de transcritos da PEPC, MDH e PEPCK ...........................................37

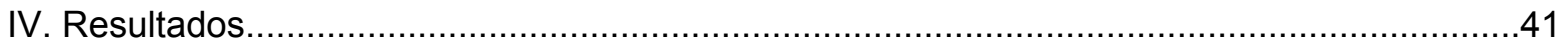

IV.1. Indução da fotossíntese CAM em plantas $C_{3}$ de abacaxizeiro........................................

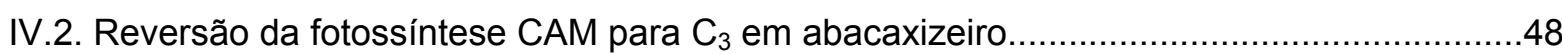

IV.3. Influência do ácido abscísico sobre a expressão do CAM em abacaxizeiro.......................52

IV.4. Influência das citocininas sobre a expressão do CAM em abacaxizeiro.............................56

IV.5. Influência das auxinas sobre a expressão do CAM em abacaxizeiro.................................62

IV.6. Influência do etileno sobre a expressão do CAM em abacaxizeiro......................................65

IV.7. Influência do cálcio citossólico sobre a expressão do CAM em abacaxizeiro.....................69

IV.8. Influência do óxido nítrico sobre a expressão do CAM em abacaxizeiro............................72

IV.9 Interação entre NO, ABA e Ca ${ }^{2+}$ citossólico na indução do CAM em abacaxizeiro..............90 
V. Discussão

VI. Conclusões

VII. Resumo

VIII. Abstract

IX. Anexo I.

126

X. Referências Bibliográficas. 


\section{LISTA DE ABREVIATURAS}

1-MCP - 1-metilciclopropeno

ABA - ácido abscísico

AIA - ácido indolilacético ou ácido indolil-3-acético

BHT - butilhidroxitolueno

BSA - albumina de soro bovino

CAM - metabolismo ácido crassuláceo

cDNA - fita de DNA complementar

CG - cromatografia a gás

cPTIO - 2-(4-carboxifenil)-4,4,5,5,-tetrametilimidazolina-1-oxil-3-óxido

DAF-2DA - 4,5 diaminofluoresceína diacetato

DEPC - dietilpirocarbonato

DNA - ácido desoxirribonucléico

dNTP - 2'-desoxinucleotídeo 5'-fosfato

DP - desvio padrão

DTT - ditiotreitol

EDTA - etilenodiamino tetra-acetato

EGTA - ácido etilenoglicol-bis(-aminoetileter)-tetracético

ELISA - do inglês "enzyme-linked immunosorbent assay"

EM - espectrometria de massa

HEPES - ácido N-(2-hidroxietilo)-piperazina-N'-2-etanesulfônico

HPLC - cromatografia líquida de alta resolução

iP - isopenteniladenina

iPR - isopenteniladenina ribosídica

$\mathrm{MDH}$ - malato desidrogenase

MOPS - ácido 3-( $N$-morfolino)-propanossulfônico

MS - matéria seca

$\mathrm{MSI}$ - monitoramento seletivo de íons

$\mathrm{NADH}$ - nicotinamida adenina dinucleotídeo reduzida

$\mathrm{NO}$ - óxido nítrico

NOC9 - 6-(2-hidroxi-1-metil-2-nitroso-hidrazino)-N-metil-1-hexanamina

NPA - ácido N-1-naftilftalâmico

$\mathrm{pb}$ - pares de base

OAA - oxaloacetato

PCR - reação em cadeia da polimerase 
PEG - polietilenoglicol

PEP - fosfoenolpiruvato

PEPC - PEP carboxilase

PEPCK - PEP carboxicinase

ppm - partes por milhão

ppt - partes por trilhão

PVP - polivinilpirrolidona

PVPP - polivinilpolipirrolidona

Rib $18 \mathrm{~S}$ - proteína ribossomal $18 \mathrm{~S}$

RNA - ácido ribonucléico

RNAm - RNA mensageiro

SDS - dodecilsulfato de sódio

SNP - nitroprussiato de sódio

Tris- $\mathrm{HCl}$ - tampão tris-(hidrometil)-aminometano-hidroclorídrico

UV - ultravioleta

Z - zeatina

ZR - zeatina ribosídeo 


\section{INTRODUÇÃO}

\section{I.1. O metabolismo ácido crassuláceo}

O metabolismo ácido crassuláceo (CAM) é uma adaptação fotossintética a condições de baixa disponibilidade hídrica ou concentrações muito reduzidas de $\mathrm{CO}_{2}$ atmosférico (LÜTTGE, 2004). Nas plantas CAM, o $\mathrm{CO}_{2}$ absorvido durante a noite é utilizado na carboxilação do fosfoenolpiruvato (PEP) pela ação da enzima PEP carboxilase (PEPC), dando origem ao oxalacetato (OAA) (CHOLLET et al., 1996). Por ação da malato desidrogenase (MDH), o OAA formado é então convertido em malato, o qual é rapidamente transportado para o vacúolo juntamente com íons $\mathrm{H}^{+}$, causando a acidificação noturna típica das plantas CAM. Durante o dia, ocorre a descarboxilação do malato e a fixação do $\mathrm{CO}_{2}$ pela enzima ribulose bifosfato carboxilase oxigenase (RUBISCO), ocasionando uma diminuição do conteúdo desse ácido nos tecidos foliares (CUSHMAN \& BOHNERT, 1999). A descarboxilação do malato pode ser realizada por dois complexos enzimáticos distintos, dependendo da espécie analisada (CHRISTOPHER \& HOLTUM, 1996). Nas espécies do tipo CAM-ME, a descarboxilação do malato é realizada diretamente pelas enzimas málicas (NAD-ME ou NADP-ME), enquanto que nas plantas do tipo CAM-PEPCK esta se dá pela ação conjunta da MDH e da PEP carboxicinase (PEPCK) (DITTRICH et al., 1973).

A capacidade que as plantas CAM possuem de restringir as trocas gasosas com a atmosfera durante o dia, faz com que elas utilizem o seu conteúdo disponível d'água mais eficientemente que as plantas $\mathrm{C}_{3}$ (DRENNAN \& NOBEL, 2000; WINTER et al., 2005), sendo dessa forma, um tipo de comportamento fotossintético muito comum entre as plantas de regiões áridas ou, ainda, de ambientes tropicais ou subtropicais, onde o suprimento hídrico é fortemente sazonal ou intermitente (OSMOND, 1978; TING, 1985; LUTTGE, 2004). 
Além disso, por se tratar de um mecanismo fotossintético concentrador de $\mathrm{CO}_{2}$, o CAM resulta na presença de altos teores desse gás no interior dos órgãos fotossintetizantes durante grande parte do período diurno (DODD et al., 2002). Com isso, a fotorrespiração nas plantas CAM é extremamente reduzida e pouco influenciada pela disponibilidade hídrica ou temperatura diurna (CUSHMAN \& BORLAND, 2002), contribuindo, portanto, para a manutenção de um balanço positivo de carbono, mesmo sob condições ambientais desfavoráveis (HERRERA et al., 2000). Também convém destacar que devido ao estabelecimento de um fluxo contínuo de $\mathrm{CO}_{2}$ durante os momentos de maior irradiância, o CAM permite um funcionamento satisfatório dos fotossistemas, ajudando, conseqüentemente, a manter a integridade do aparato fotossintético em condições climáticas adversas (LÜTTGE, 2004).

O comportamento CAM também confere uma extraordinária flexibilidade fisiológica, permitindo ampliar a capacidade de ajuste do metabolismo das plantas às variações nas condições ambientais (CUSHMAN \& BORLAND, 2002). Variações nos padrões ou teores de expressão do CAM podem ser encontradas entre espécies ou populações distintas ou, ainda, em um mesmo indivíduo dependendo, do seu estágio de desenvolvimento ou das condições ambientais (BORLAND et al., 1998; DODD et al., 2002; LUTTGE, 2004; WINTER et al., 2008).

Embora todas as plantas CAM apresentem certo grau de plasticidade fisiológica, a capacidade de realizar ajustes no metabolismo fotossintético é especialmente marcante entre as espécies ditas $\mathrm{C}_{3}$-CAM facultativas (CUSHMAN \& BORLAND, 2002; WINTER et al., 2008). Essas espécies, quando em condições ambientais adequadas, realizam a absorção do $\mathrm{CO}_{2}$ principalmente durante o dia, maximizando seu crescimento por meio da fotossíntese $\mathrm{C}_{3}$ (LUTTGE et al., 2004). Por outro lado, quando fatores ambientais como luminosidade excessiva, baixo suprimento hídrico ou altas temperaturas tornam a absorção diurna do $\mathrm{CO}_{2}$ menos favorável, essas plantas passam a apresentar o comportamento CAM, o qual permite a manutenção da atividade 
fotossintética e o crescimento mesmo sob essas condições desfavoráveis (BORLAND et al., 1998; TAYBI \& CUSHMAN, 1999; TAYBI et al., 2002).

Espécies $\mathrm{C}_{3}$-CAM facultativas podem ser encontradas em diversas famílias vegetais, incluindo Aizoaceae, Crassulaceae, Portulaceae, Vitaceae, Clusiaceae e Bromeliaceae. De forma condizente, a maioria dos estudos acerca da regulação da fotossíntese CAM tem se concentrado em espécies $\mathrm{C}_{3}$-CAM facultativas, uma vez que nessas plantas, a expressão diferencial de genes induzidos em resposta aos estímulos ambientais serve como um bom indicador das mudanças metabólicas necessárias para a expressão desse tipo de comportamento fotossintético (CUSHMAN \& BORLAND, 2002).

\section{I.2. A sinalização da indução do CAM}

O estabelecimento da fotossíntese CAM requer um grande número de enzimas, transportadores e proteínas acessórias; assim sendo, a indução desse tipo de comportamento fotossintético é uma das mais complexas adaptações metabólicas em resposta aos estresses abióticos (CUSHMAN \& BORLAND, 2002). Além disso, um nível similar de complexidade também tem sido demonstrado no que tange ao controle da intensidade de expressão desse metabolismo fotossintético, envolvendo uma considerável gama de fatores ambientais, fitormônios e mensageiros secundários (TAYBI et al., 2002).

\section{O ácido abscísico na indução do CAM}

O ácido abscísico (ABA) regula vários processos no ciclo de vida das plantas, estando envolvido na maioria das respostas aos estresses ambientais, incluindo o déficit hídrico, salinidade e as baixas temperaturas (KIM, 2007). De modo geral, plantas submetidas a condições de estresse hídrico ou salino apresentam incrementos consideráveis no conteúdo endógeno de ABA (THOMAS et al., 1992; POSPISILOVA et 
al., 2005), os quais parecem ser decorrentes principalmente de uma aumento na síntese desse hormônio (ORITANI \& KIYOTA, 2003; NAMBARA \& MARION-POLL, 2005).

Muitos genes associados com respostas de defesa a estresses abióticos, como o frio e o estresse hídrico, são expressos apenas quando os teores de ABA são elevados (BARTELS E SUNKAR, 2005). Por outro lado, sabe-se que vários outros genes induzidos por estresses ambientais são indiferentes ao tratamento com ABA exógeno, indicando a existência de, pelo menos, dois caminhos de expressão gênica em resposta ao estresse: um dependente e outro independente do ABA (GOSTI et al., 1995; RIERA et al. 2005). Os efeitos do ácido abscísico na proteção ao estresse hídrico são exercidos principalmente através da indução da expressão de genes que codificam a síntese de proteínas com função de evitar as perdas de água e restaurar os danos celulares. Entretanto, muitas outras respostas fisiológicas de grande valor adaptativo para a sobrevivência das plantas em condições de baixa disponibilidade hídrica também são controladas pelo ácido abscísico.

Sabe-se, por exemplo, que o ABA constitui a classe hormonal que apresenta maior influência sobre a mudança da fotossíntese $C_{3}$ para CAM (TAYBI et al., 2002). Um dos primeiros relatos do papel indutor do $A B A$ na transição da fotossíntese $C_{3}$ para o CAM foi realizado por TING (1981). Nesse trabalho foi observado que o tratamento de plantas de Portulacaria afra, uma espécie $\mathrm{C}_{3}$-CAM facultativa, com ABA desencadeou o fechamento estomático durante o dia e o acúmulo de ácidos orgânicos nos tecidos foliares durante o período noturno, eventos esses característicos do comportamento CAM.

Posteriormente, CHU et al. (1990) demonstraram que a aplicação de ABA podia substituir o estresse hídrico ou a salinidade na indução do comportamento CAM em plantas de Mesembryanthemum crystallinum, induzindo a atividade da PEPC e levando ao aumento na concentração de ácido málico durante o período noturno. De modo complementar, DAl et al. (1994), trabalhando com essa mesma espécie, demonstraram 
que a aplicação de ABA também resultou em um aumento considerável na abundância do RNAm de isoformas da PEPC específicas do comportamento CAM.

Mais recentemente, estudos demonstraram que a indução do CAM em resposta ao ABA envolve aumentos nos teores de transcritos de diversas enzimas-chave desse tipo de metabolismo fotossintético, tais como a PEPC (TAYBI et al., 1995; TAYBI \& CUSHMAN, 1999; TAYBI et al., 2002, 2004), a MDH (TAYBI \& CUSHMAN, 1999), a gliceraldeído-3-fosfato desidrogenase (TAYBI \& CUSHMAN, 1999), a enolase (FORSTHOEFEL et al., 1995a), a fosfogliceromutase (FORSTHOEFEL et al., 1995b) e a subunidade C da ATPase vacuolar (BARKLA et al., 1999).

Aparentemente, a sinalização entre as raízes e a parte aérea não é essencial para a indução do CAM, tendo em vista que folhas isoladas de Kalanchöe blossfeldiana e M. crystallinum (TAYBI et al., 1995; TAYBI \& CUSHMAN, 1999) foram induzidas ao CAM em resposta ao $\mathrm{ABA}$, estresse hídrico ou salinidade. Além disso, a indução ao CAM pela aplicação de ABA não requer a diminuição no conteúdo hídrico foliar, ocorrendo mesmo em tecidos completamente túrgidos (CHU et al., 1990).

Estudos também constataram que aumentos dramáticos no conteúdo endógeno de ABA precedem a indução do comportamento CAM em resposta ao estresse hídrico ou salino (THOMAS et al., 1992; TAYBI et al., 1995; TAYBI \& CUSHMAN, 2002), sugerindo a participação desse fitormônio como um mediador desses estresses ambientais. Entretanto, trabalhos realizados com plantas de $M$. crystallinum, demonstraram que a inibição do acúmulo de ABA, por meio da aplicação de inibidores de sua síntese, não impediu a indução do CAM nessa espécie, indicando que o aumento na concentração desse fitormônio não representa uma etapa essencial durante a indução do comportamento CAM (THOMAS et al., 1992; TAYBI \& CUSHMAN, 2002).

Assim sendo, embora o envolvimento do $A B A$ na indução do CAM tenha sido demonstrado em algumas espécies $\mathrm{C}_{3}$-CAM facultativas, ainda não é claro se esse fitormônio atuaria como um sinalizador primário ou como um dos componentes na 
cascata de sinalização dessa mudança de comportamento fotossintético (CUSHMAN \& BORLAND, 2002).

\section{As citocininas na indução do CAM}

As citocininas constituem uma importante classe de hormônios vegetais, uma vez que regulam diversos aspectos do crescimento e desenvolvimento vegetal, incluindo divisão celular, dominância apical, formação dos cloroplastos, senescência de tecidos e orgãos, mobilização de nutrientes e atividade enzimática (MOK \& MOK, 2001; CHOI \& HWANG, 2007; SAKAKIBARA, 2006). Adicionalmente, as citocininas antagonizam muitos processos fisiológicos desencadeados pelo estresse hídrico ou salino, especialmente aqueles mediados pelo ABA (POSPISILOVA et al., 2000). Exemplos de eventos fisiológicos influenciados pelo antagonismo entre as citocininas e o ABA incluem o fechamento estomático, a abscisão de frutos e a senescência foliar (NAQVI, 1995). Além disso, a aplicação de citocininas reduz os efeitos negativos do estresse hídrico sobre o conteúdo de clorofilas e carotenóides, além de estimular a recuperação da fotossíntese líquida após a reidratação dos tecidos vegetais (RULCOVA \& POSPISILOVA, 2001; VOMACKA \& POSPISILOVA, 2003). Sabe-se, ainda, que plantas expostas a condições de baixa disponibilidade hídrica geralmente apresentam reduções consideráveis no conteúdo endógeno de citocininas (POSPISILOVA et al., 2000).

A participação das citocininas como promotoras da indução do CAM já foi relatada por alguns autores (SCHMITT \& PIEPENBROCK, 1992; THOMAS et al., 1992). THOMAS et al. (1992) constataram que a aplicação de 6-benziladenina (BA), zeatina (Z) ou isopenteniladenina (iP) ao sistema radicular de plantas de $M$. crystallinum resultou em um aumento nos teores de proteína da PEPC equivalente ao observado nas plantas induzidas ao CAM em resposta ao estresse salino. De modo similar, foi verificado que o a adição de BA ao meio de crescimento de plantas dessa mesma espécie também 
resultou em um aumento nos teores de atividade das enzimas PEPC e ME, bem como no acúmulo noturno de malato e acidez titulável (DAl et al., 1994).

Entretanto, estudos mais detalhados têm caracterizado as citocininas como reguladoras negativas da expressão do CAM (PETERS et al., 1997; CUSHMAN \& BORLAND, 2002; TAYBI et al., 2002). Em um desses trabalhos, SCHMITT \& PIEPENBROCK (1992) demonstraram que plantas de M. crystallinum pulverizadas com BA apresentaram uma inibição intensa no acúmulo de transcritos da PEPC em resposta ao estresse salino, sendo essa resposta independente de alterações no conteúdo hídrico das plantas. Além disso, esses autores constataram que a aplicação BA também resultou em reduções consideráveis nos teores de RNAm da PEPC em folhas isoladas dessa espécie mesmo quando estas foram expostas à condição de estresse hídrico (SCHMITT \& PIEPENBROCK, 1992). Posteriormente, PETERS et al. (1997) obtiveram resultados similares quando folhas de plantas de $M$. crystallinum mantidas na presença de estresse hídrico foram tratadas com BA. Verificou-se, ainda, que durante a indução de plantas dessa espécie ao CAM por estresse hídrico, houve uma redução significativa no conteúdo de citocininas e um aumento pronunciado na quantidade de transcritos da PEPC, corroborando com a atual proposição de um papel sinalizador negativo para essa classe hormonal (PETERS et al., 1997).

\section{$\underline{\text { Auxinas, giberelinas e etileno na indução do CAM }}$}

Ao contrário do observado para as citocininas e para o ácido abscísico, estudos acerca da influência de outras classes hormonais sobre a expressão do CAM são notavelmente raros na literatura (TAYBI et al., 2002).

Com relação às auxinas, tem-se apenas o relato de que a aplicação do ácido 2,4diclorofenoxiacético (2,4-D) não apresentou efeito na indução ao CAM em plantas de $M$. crystallinum (DAl et al., 1994). Do mesmo modo, um único trabalho analisou a influência do etileno sobre a indução do CAM, revelando que o tratamento de plantas de $M$. 
crystallinum com esse regulador de crescimento não resultou em aumentos na expressão do RNAm da PEPC ou no acúmulo noturno de L-malato (HURST et al., 2004).

Posteriormente, GURALNICK et al. (2001) constataram que plantas de $M$. crystallinum tratadas com GA apresentaram um discreto aumento na quantidade de proteína e atividade da PEPC. Contudo, esses autores discutem que esse efeito indutor parece ser decorrente da aceleração no desenvolvimento das plantas estimulado pela aplicação desse hormônio, não consistindo, portanto, em um papel sinalizador primário (GURALNICK et al., 2001).

\section{Sinais secundários envolvidos na indução do CAM}

Estudos realizados com $M$. crystallinum têm revelado alguns dos mensageiros secundários envolvidos na indução do CAM, entre eles o cálcio citossólico, as proteínas cinases, as proteínas fosfatases e os fosfoinositóis (TAYBI \& CUSHMAN, 1999; TAYBI et al., 2002).

Mudanças na concentração de cálcio intracelular regulam muitos processos nas plantas, incluindo as respostas hormonais e aos estresses abióticos (MEDVEDEV, 2005; DODD et al., 2005). Estresses ambientais como baixa temperatura, choque térmico, salinidade, seca, anóxia, patógenos, estresse osmótico, injúria mecânica e estresse oxidativo induzem aumentos transientes nos teores citossólico de $\mathrm{Ca}^{2+}$ (MENDELEV, 2005). Além disso, estudos realizados por TAYBI \& CUSHMAN (1999) demonstraram que o aumento na concentração de $\mathrm{Ca}^{2+}$ citossólico é essencial para a indução da fotossíntese CAM em M. crystallinum. Esses autores observaram que o tratamento de folhas dessa espécie com um quelante de $\mathrm{Ca}^{2+}$ extracelular, antes da aplicação do estresse hídrico ou $\mathrm{ABA}$, inibiu completamente o aumento no teor de transcritos da PEPC (TAYBI \& CUSHMAN, 1999). Além disso, o tratamento com ionóforos de cálcio resultou no aumento do teor de transcritos da PEPC mesmo em folhas não expostas às condições indutoras do CAM (TAYBI \& CUSHMAN, 1999). Ainda nesse trabalho, 
experimentos realizados com bloqueadores de canais de $\mathrm{Ca}^{2+}$ indicaram que canais do tipo L também podem estar envolvidos na indução do CAM (TAYBI \& CUSHMAN, 1999). Assim sendo, esses autores concluíram que aumentos na concentração de cálcio citossólico encontram-se envolvidos nas vias de sinalização da indução de $M$. crystallinum ao CAM em resposta ao estresse hídrico, salinidade ou à aplicação de ABA (TAYBI \& CUSHMAN, 1999).

Além do cálcio citossólico, ensaios de fosforilação in vitro indicaram que a fosforilação de proteínas também pode fazer parte da via de transdução de sinal durante a indução do CAM (TAYBI et al., 2002). Foi constatado que o tratamento de folhas de $M$. crystallinum com substâncias inibidoras da atividade das proteínas cinases dependentes de $\mathrm{Ca}^{2+}$ inibiu completamente a indução de genes relacionados com o comportamento CAM (TAYBI \& CUSHMAN, 1999). Além disso, uma forte correlação foi observada entre a abundância dessas proteínas cinases e o aumento na transcrição dos genes de proteínas-chave da fotossíntese CAM (TAYBI \& CUSHMAN, 1999). Também foi observado que o pré-tratamento das folhas de $M$. crystallinum com inibidores de proteínas fosfatases do tipo $2 \mathrm{~A}$ e 1 reprimiu completamente o acúmulo de transcritos da PEPC em resposta ao estresse hídrico (TAYBI \& CUSHMAN, 1999).

Complementarmente, TAYBI \& CUSHMAN (1999) constataram que quando folhas isoladas de $M$. crystallinum eram tratadas com diferentes concentrações de inositol 1,4,5-trifosfato $\left(\mathrm{IP}_{3}\right)$ havia um aumento considerável nos teores de transcritos da PEPC, sugerindo que fosfoinositóis também participariam da sinalização do CAM nessa espécie.

Contudo, as participações do $\mathrm{Ca}^{2+}$ citossólico, do $\mathrm{IP}_{3}$, das proteínas cinases dependentes de $\mathrm{Ca}^{2+}$ e das proteínas fosfatases como mensageiros secundários na indução ao CAM foram demonstradas apenas em M. crystallinum (TAYBI \& CUSHMAN, 1999), faltando, dessa forma, estudos acerca da abrangência do envolvimento desses elementos na via de transdução de sinal da indução do CAM em outras espécies. Além disso, visto que os demais passos da sinalização da indução do CAM são pouco 
compreendidos, o estudo da influência de outros compostos sinalizadores nesse processo tem atraído considerável interesse (TAYBI et al., 2002).

\section{Um novo sinalizador nas plantas: o óxido nítrico}

O óxido nítrico (NO) é um composto gasoso, inorgânico, lipofílico, de pequeno tamanho molecular e moderada solubilidade em água. Como um radical livre, o NO reage muito rapidamente com outros átomos e moléculas que contêm elétrons desemparelhados formando derivados mais estáveis (MAGALHÃES et al., 2005; NEILL et al., 2008). Embora a produção de NO por tecidos vegetais tenha sido observada pela primeira vez por KLEPPER em 1975, até pouco tempo atrás, pesquisas acerca dos efeitos do NO em plantas abordaram apenas aspectos relacionados à poluição atmosférica por óxidos de nitrogênio como, por exemplo, sua absorção, metabolismo e fitotoxicidade (WELLBURN, 1990; HUFTON et al., 1996). Estudos subseqüentes viriam demonstrar que as plantas não somente respondem ao NO atmosférico, mas também são capazes de modular a produção desse gás durante diversos processos fisiológicos (MAGALHÃES et al., 1999, 2000, 2005, 2006; WILDT et al., 1997). Desde então, tem sido observado um aumento crescente no número de relatos demonstrando novos efeitos do NO em plantas (MAGALHÃES et al., 1999, 2006; BRIGHT et al., 2006; KAISER \& PLANCHET, 2006; CRAWFORD, 2006).

Atualmente, tem-se conhecimento do papel regulatório do NO numa considerável gama de processos relacionados ao metabolismo, crescimento e desenvolvimento vegetal, como por exemplo, no atraso da senescência (LESHEM \& HARAMATY, 1996; MISHINA et al., 2007), morte celular programada (MAGALHÃES et al., 1999; PEDROSO et al., 2000), expressão de genes relacionados à defesa contra patógenos (DURNER et al., 1998; GRÜN et al., 2006), fechamento estomático (GARCÍA-MATA \& LAMATTINA, 2001, 2002, 2003; NEILL et al., 2008), expansão foliar e radicular (GOUVÊA et al., 1997, LESHEM \& HARAMATY, 1996; ZHAO et al., 2007), germinação de sementes, síntese 
de clorofila, estiolamento caulinar (BELIGNI \& LAMATTINA, 2000, ZHANG et al., 2006), desenvolvimento de raízes adventíceas (PAGNUSSAT et al., 2002, 2003, 2004), floração (HE et al., 2004), entre outros. Todavia, estudos sobre a produção e função do NO em plantas são ainda relativamente escassos, quando comparados com a vasta literatura acerca dos efeitos do NO em animais e humanos (LAMATTINA et al., 2003; GRÜN et al., 2006; ARASIMOWICZ \& FLORYSZAK-WIECZOREK, 2007).

Muitas dúvidas permanecessem quanto ao real papel do NO nas plantas, tanto que alguns autores o classificam como um mensageiro secundário de fitormônios (MAGALHÃES et al., 2000; PAGNUSSAT et al., 2003, NEILL et al., 2008), enquanto que outros sugerem ser ele próprio um novo hormônio vegetal, uma vez que, é produzido em baixas concentrações, atua de maneira dose-dependente e possui fácil difusão nos tecidos (BELIGNI \& LAMATTINA, 2001; LAMATTINA et al., 2003).

Apesar dessas dúvidas, um grande número de relatos tem demonstrado que o NO é capaz de interagir com praticamente todas as classes de hormônios vegetais durante a sinalização de eventos fisiológicos em plantas (PAGNUSSAT et al., 2003, NEILL, 2007). Sabe-se, por exemplo, que auxinas, citocininas e ácido abscísico (ABA) estimulam a produção de NO em várias espécies vegetais e, em contrapartida, diversas respostas fisiológicas desencadeadas por essas três classes hormonais podem ser mimetizadas pela aplicação de NO ou inibidas pela sua remoção dos tecidos (TUN et al., 2001, 2008; PAGNUSSAT et al., 2002, 2003; SCHERER \& HOLK, 2000, NEILL, 2007; NEILL et al., 2008; KOLBERT et al., 2008). De modo semelhante, a participação do NO na germinação de sementes e no alongamento caulinar também sugere a atuação desse gás como um mediador em processos controlados por giberelinas (GIBA et al., 1998; BELIGNI \& LAMATTINA, 2000; BETHKE et al., 2007).

Outros trabalhos também indicam que o NO interage com as vias de sinalização do ácido salicílico e do ácido jasmônico, especialmente durante as respostas ao ataque de patógenos ou injúrias (DURNER et al., 1998; OROZCO-CARDENAS \& RYAN, 2002; 
HUANG et al., 2002, 2004; WANG \& WU, 2005; XU et al., 2005). Adicionalmente, existem relatos de aumentos na produção de $\mathrm{NO}$ em plantas submetidas ao tratamento com poliaminas (TUN et al., 2006; YAMASAKI \& COHEN, 2006).

Por outro lado, evidências da interação entre NO e etileno na maturação e senescência de tecidos vegetais sugerem um efeito antagonista entre esses gases (MAGALHÃES et al., 2000; LESHEM et al., 1998; LESHEM \& PINCHASOV, 2000), o qual tem sido corroborado pela descoberta do papel inibitório do NO sobre a expressão de enzimas-chaves na via de biossíntese de etileno (PARANI et al., 2004; ARASIMOWICZ \& FLORYSZAK-WIECZOREK, 2007).

Além disso, tem-se conhecimento que a produção de NO nos tecidos vegetais é fortemente modulada pelas condições ambientais (MAGALHÃES et al., 2006) e, de modo condizente, alterações no conteúdo endógeno desse radical livre parecem ser importantes na sinalização de diversas respostas a estresses abióticos como, por exemplo, temperaturas elevadas (GOULD et al., 2003), salinidade (RUAN et al., 2004a, 2004b; ZHAO et al., 2004; SHI et al., 2007), radiação UV (AN et al., 2005; TIAN \& LEI, 2007), metais pesados (KOPYRA \& GWOZDZ, 2003), ozônio (EDERLI et al., 2006) e estresse hídrico (NEILL, 2007; SANG et al., 2008a; XING et al., 2004; NEILL et al., 2008; LEl et al., 2007; HAO et al., 2008).

Trabalhos têm demonstrado que a aplicação de NO resultou em aumento na tolerância ao frio em plantas de tomate, trigo, milho e tabaco (NIELL et al., 2003; GOULD et al., 2003, ARASIMOWICZ \& FLORYSZAK-WIECZOREK, 2007) e que, além disso, tecidos vegetais submetidos a tratamentos de alta temperatura apresentaram incrementos na síntese de óxido nítrico (GOULD et al., 2003). Outros indícios também apontam para a participação do NO nas respostas ao UV-B, uma vez que foram verificadas elevações na produção de óxido nítrico durante a exposição de plantas a esse tipo de radiação (HE et al., 2005; AN et al., 2005), bem como foi constatada uma 
maior tolerância ao UV-B em tecidos vegetais pré-tratados com compostos doadores de NO (NIELL et al., 2003; TIAN \& LEI, 2007; NIELL et al., 2008).

No que tange à atuação do NO em respostas das plantas à salinidade, foi demonstrado, por exemplo, que o tratamento com doadores de NO promoveu incrementos na atividade das enzimas antioxidantes e na expressão de genes de resistência à salinidade, além de reduzir a perda de produtividade em plântulas de arroz submetidas ao estresse salino (UCHIDA et al., 2002). A suplementação de tecidos vegetais com NO também parece resultar na amenização dos efeitos destrutivos de estresses por metais pesados e herbicidas, promovendo incrementos consideráveis nas atividades de enzimas antioxidantes e, conseqüentemente, redução nos danos celulares causados pelo estresse oxidativo gerado nessas condições (HUNG, et al., 2002; KOPYRA \& GWOZDZ, 2003).

Tendo em vista que o estresse hídrico representa um dos principais estresses abióticos que limitam a produtividade vegetal, diversos grupos de pesquisa têm analisado a influência do NO em respostas fisiológicas associadas a reduções na disponibilidade hídrica (GARCIA-MATA \& LAMATTINA, 2001, 2002, 2003; DESIKAN et al., 2004; XING et al., 2004; NEILL et al., 2008; LEl et al., 2007; HAO et al., 2008). Uma das primeiras pesquisas acerca da produção do NO em plantas submetidas ao estresse hídrico foi conduzido por LESHEM \& HARAMATY (1996). Esses autores relataram que plantas de Pisum sativum sofreram um aumento na produção de NO de modo proporcional ao tempo de exposição à condição de estresse hídrico (LESHEM \& HARAMATY, 1996). De modo condizente, alterações substanciais na produção de NO também têm sido relatadas em diversas espécies de plantas expostas ao estresse hídrico (MAGALHÃES et al., 2000, ZHAO et al., 2001; HAO et al., 2008; KOLBERT et al., 2008).

Embora algumas respostas ao estresse hídrico tenham sido alvo de estudos intensos, os quais originaram grande parte do conhecimento atual sobre os mecanismos 
de ação do NO em plantas (DESIKAN et al., 2004; NEILL, 2007), muitos eventos fisiológicos desencadeados pela limitação no suprimento hídrico permanecem ainda não analisados quanto ao envolvimento desse radical livre como um possível sinalizador (ARASIMOWICZ \& FLORYSZAK-WIECZOREK, 2007; NEILL et al., 2008). Esse é o caso, por exemplo, da indução da fotossíntese CAM em plantas $C_{3}-C A M$ facultativas.

Com base no conhecimento atual sobre a influência do NO em respostas desencadeadas pelo estresse hídrico e fitormônios, nos parece bastante plausível admitir que haja o envolvimento do NO na sinalização da indução do metabolismo ácido crassuláceo, uma vez que tanto o estresse hídrico quanto o ABA estimulam a produção endógena desse radical livre em tecidos vegetais (LESHEM E HARAMATY, 1996; GARCIA-MATA \& LAMATTINA, 2002), e esses mesmos fatores resultam na indução da fotossíntese CAM na maioria das espécies $\mathrm{C}_{3}$-CAM facultativas já analisadas (TAYBI et al., 2002).

\section{I.3. O abacaxizeiro como modelo para estudos da sinalização da expressão do CAM}

A maioria dos estudos acerca dos sinais ambientais e endógenos que regulam a expressão do CAM tem se restringido à espécie Mesembryanthemum crystallinum (THOMAS et al., 1992; SCHMITT \& PIEPENBROCK, 1992; TAYBI \& CUSHMAN, 1999; CUSHMAN, 2001; TAYBI et al., 2002). Essa espécie tem sido inclusive proposta por alguns autores como uma planta modelo para estudos da indução do CAM, tendo em vista sua facilidade de cultivo em condições de laboratório, seu rápido ciclo de vida (6 semanas) e seu genoma relativamente pequeno (CUSHMAN, 2001; CUSHMAN \& BORLAND, 2002; CUSHMAN et al., 2008). Contudo, assim como outras espécies pertencentes à família Aizoaceae, M. crystallinum sofre uma transição gradual do metabolismo $\mathrm{C}_{3}$ para o CAM ao longo da ontogenia, o qual pode ocorrer mesmo na ausência dos sinais ambientais indutores do CAM, tais como, alterações no 
fotoperiodismo, déficit hídrico ou salinidade (HERPPICH et al., 1992; CUSHMAN, 2001; CUSHMAN \& BORLAND, 2002). Além disso, a indução do CAM nessa espécie ocorre de modo irreversível, impossibilitando, portanto, avaliar os mecanismos de sinalização envolvidos na reversão da fotossíntese CAM para $\mathrm{C}_{3}$.

Em contrapartida, sabe-se que as espécies $\mathrm{C}_{3}$-CAM facultativas pertencentes às famílias Clusiaceae e Bromeliaceae podem alternar entre a fotossíntese $C_{3}$ e CAM de maneira rápida e reversível em resposta à alterações ambientais, independentemente da ontogenia foliar ou da planta (SMITH et al., 1986; MAXWELL et al. 1995; ZOTZ E WINTER, 1993; BORLAND et al., 1998; CUSHMAN \& BORLAND, 2002; LUTTGE, 2006). Na família Bromeliaceae, por exemplo, a espécie melhor caracterizada quanto à capacidade de ciclar, de modo reversível, entre a fotossíntese $C_{3}$ e CAM consiste na epífita Guzmania monostachia (MEDINA et al., 1977; GRIFFITHS \& SMITH, 1983; SMITH et al., 1986; MAXWELL et al., 1992, 1994, 1995, 1999; MAXWELL, 2002). Contudo, existem relatos da ocorrência de espécies $\mathrm{C}_{3}$-CAM facultativas também nos gêneros Greigia, Puya, Billbergia, Wittrockia, Catopsis, Nidularium e Vriesea (MARTIN, 1994; BENZING, 2000).

Em uma revisão realizada por MARTIN (1994), foi relatado que dentre as 249 espécies de bromélias epífitas e terrestres analisadas quanto ao tipo de metabolismo fotossintético, cerca de $31 \%$ do total apresentavam metabolismo do tipo $\mathrm{C}_{3}$ e $69 \%$ exibiam comportamento CAM ou então $\mathrm{C}_{3}$-CAM facultativo. Mais recentemente, CRAYN et al. (2004) analisaram o tipo de comportamento fotossintético de 1873 espécies de bromélias e constataram que cerca de $44 \%$ do total apresentavam a capacidade de expressar o CAM.

Estudos sobre fotossíntese em bromélias terrestres foram conduzidos, em sua maioria, em espécies do gênero Ananas, especialmente, Ananas comosus (MARTIN, 1994). Parte desses trabalhos considera o abacaxizeiro como uma espécie CAM constitutiva, ou seja, mesmo em condições ideais de crescimento, essa bromélia expressaria o metabolismo ácido crassuláceo (MEDINA et al., 1994; SAYED, 2001). 
Contudo, TING (1985) relatou que dependendo das condições de intensidade luminosa, temperatura e disponibilidade hídrica, $A$. comosus poderia apresentar comportamento fotossintético do tipo $\mathrm{C}_{3}$ ou CAM. Foi verificado que plantas dessa espécie quando irrigadas adequadamente, comportavam-se como $\mathrm{C}_{3}$, e quando o suprimento hídrico era prejudicado, alternavam para o comportamento CAM (TING, 1985). Esse autor também ressalta que em abacaxizeiro, assim como em outras espécies $\mathrm{C}_{3}$-CAM facultativas, temperaturas altas durante o dia, associadas à baixas temperaturas noturnas, favorecem o acúmulo de ácidos orgânicos e o metabolismo ácido crassuláceo (TING, 1985).

Em concordância com essas observações, NEALES et al. (1980) constataram que a temperatura influiu no padrão de absorção de $\mathrm{CO}_{2}$ em $A$. comosus. Nesse trabalho foi constatado que quando plantas de abacaxizeiro foram cultivadas num regime de $30^{\circ} \mathrm{C}$ dia $/ 15^{\circ} \mathrm{C}$ noite, a maior absorção de $\mathrm{CO}_{2}$ ocorreu durante o período noturno, evidenciando o estabelecimento do comportamento CAM. Já em condições de temperatura constante de $30^{\circ} \mathrm{C}$ durante dia e noite, essa bromélia apresentava uma maior absorção de $\mathrm{CO}_{2}$ durante o período iluminado, com um padrão típico de fotossíntese $\mathrm{C}_{3}$ (NEALES et al.,1980). De forma similar, outros trabalhos também têm relatado a ocorrência de reduções na assimilação de $\mathrm{CO}_{2}$ durante a noite em plantas de A. comosus submetidas a aumentos na temperatura noturna (ZHU et al., 1999; LIN et al., 2006).

Além disso, trabalhos realizados em nosso laboratório, demonstraram que plantas de abacaxizeiro cultivadas in vitro sob temperatura constante de $28^{\circ} \mathrm{C}$ apresentaram baixos teores de atividade da PEPC e de ácidos orgânicos ao longo do ciclo diurno, indicando a ocorrência de fotossíntese do tipo $C_{3}$ (NIEVOLA et al., 2005). Nessa pesquisa também foi observado que as plantas de $A$. comosus cultivadas in vitro podiam ser induzidas ao comportamento CAM por ação termoperiódica. Verificou-se que quando as plantas dessa bromélia foram cultivadas sob termoperíodo de $28^{\circ} \mathrm{C}$ dia $/ 15^{\circ} \mathrm{C}$ noite, estas apresentaram variações nos teores de acidez titulável e na atividade da 
PEPC durante o ciclo diurno compatíveis com os de uma planta CAM. Adicionalmente, foram constatadas diferenças morfológicas e histológicas marcantes entre as plantas $\mathrm{C}_{3}$ e CAM, destacando-se o incremento da suculência nessas últimas (NIEVOLA et al., 2005). Essa capacidade de ciclar entre a fotossíntese $C_{3}$ e CAM em condições de cultivo estritamente controladas, torna o abacaxizeiro um modelo favorável para estudos da sinalização durante a indução ao CAM.

Assim sendo, diante da recente caracterização do abacaxizeiro cultivado in vitro como um modelo para estudos da indução do metabolismo ácido crassuláceo e tendo em vista o limitado conhecimento atual acerca dos sinais endógenos envolvidos no controle da expressão desse tipo de comportamento fotossintético em bromélias $\mathrm{C}_{3^{-}}$ CAM facultativas, o presente estudo buscou analisar o envolvimento de quatro classes hormonais (ABA, citocininas, auxinas e etileno), do $\mathrm{Ca}^{2+}$ citossólico e do óxido nítrico na regulação da expressão do CAM nessa espécie. Procurou-se identificar possíveis correlações entre os teores endógenos desses compostos e os processos de indução e de reversão do CAM em abacaxizeiro, bem como analisar os efeitos de tratamentos de modulação da concentração, transporte ou percepção desses sinalizadores durante a determinação do tipo de comportamento fotossintético apresentado por essa bromélia. 


\section{OBjetivos}

O presente trabalho teve como principal objetivo estudar a participação de quatro classes hormonais (ABA, citocininas, auxinas e etileno), do $\mathrm{Ca}^{2+}$ citossólico e do óxido nítrico na sinalização da indução do metabolismo ácido crassuláceo em Ananas comosus. Para atingir tal objetivo, as seguintes metas foram propostas:

1. Caracterizar o período de indução e de reversão do CAM nessa bromélia, por meio da quantificação do acúmulo noturno de malato e dos teores de transcritos e de atividade de enzimas-chave desse tipo de comportamento fotossintético (PEPC, MDH e PEPCK).

2. Analisar as variações nos teores de $A B A$, citocininas ( $Z, Z R$, iP e iPR), AIA, etileno, e NO durante os períodos que abrangem a mudança da fotossíntese $C_{3}$ para CAM e a reversão do comportamento CAM para $\mathrm{C}_{3}$ em $A$. comosus.

3. Verificar a influência de tratamentos de suplementação com ABA, citocininas, AIA, etileno, $\mathrm{Ca}^{2+}$ citossólico e NO sobre os níveis de expressão do CAM em abacaxizeiro.

4. Avaliar a influência de tratamentos com compostos inibidores da síntese, transporte ou percepção de ABA, auxinas, etileno, $\mathrm{Ca}^{2+}$ citossólico e NO sobre o tipo de comportamento fotossintético apresentado por $A$. comosus.

5. Analisar, in situ, a produção de NO nos tecidos foliares de abacaxizeiro durante a indução da fotossíntese CAM.

6. Investigar a existência de interações entre o ABA, o $\mathrm{NO}$ e o $\mathrm{Ca}^{2+}$ citossólico durante a indução do CAM em A. comosus. 


\section{MATERIAL E MÉtOdOS}

\section{III.1. Obtenção do material vegetal}

As plantas de Ananas comosus (L.) Merr. var. Smooth Cayenne foram obtidas por micropropagação, utilizando-se segmentos nodais como explantes (NIEVOLA et al., 2005). Para tanto, plantas de abacaxizeiro com cerca de 8 meses (Figura 1A) tiveram suas folhas cortadas, uniformizando a altura dos eixos caulinares em cerca de $1 \mathrm{~cm}$ (Figura 1B). Posteriormente, esses eixos caulinares foram transferidos para uma câmara escura em frascos de vidro contendo $100 \mathrm{~mL}$ de meio de cultura de MURASHIGE \& SKOOG (1962), na forma gelificada (2 g.L $\mathrm{L}^{-1}$ de Phytagel $\left.{ }^{\circledR}\right)$ e acrescido de $100 \mathrm{mg} \cdot \mathrm{L}^{-1}$ de mioinositol e $0.1 \mathrm{mg} \cdot \mathrm{L}^{-1}$ de tiamina (meio MS básico), onde permaneceram por 2 meses a fim de promover o estiolamento caulinar (Figura 1C). Segmentos nodais de aproximadamente $1 \mathrm{~cm}$ foram obtidos seccionando-se os eixos caulinares estiolados (Figura 1D), e em seguida, inoculados em novo meio de cultura MS básico onde foram cultivados por 3 meses sob fotoperíodo de 16 horas, intensidade luminosa de 55 $\mu$ moles $\mathrm{m}^{-2} \cdot \mathrm{s}^{-1}$ e temperatura constante de $25 \pm 2^{\circ} \mathrm{C}$, regenerando novas plantas a partir do desenvolvimento dos primórdios de gemas axilares (Figura 1E).

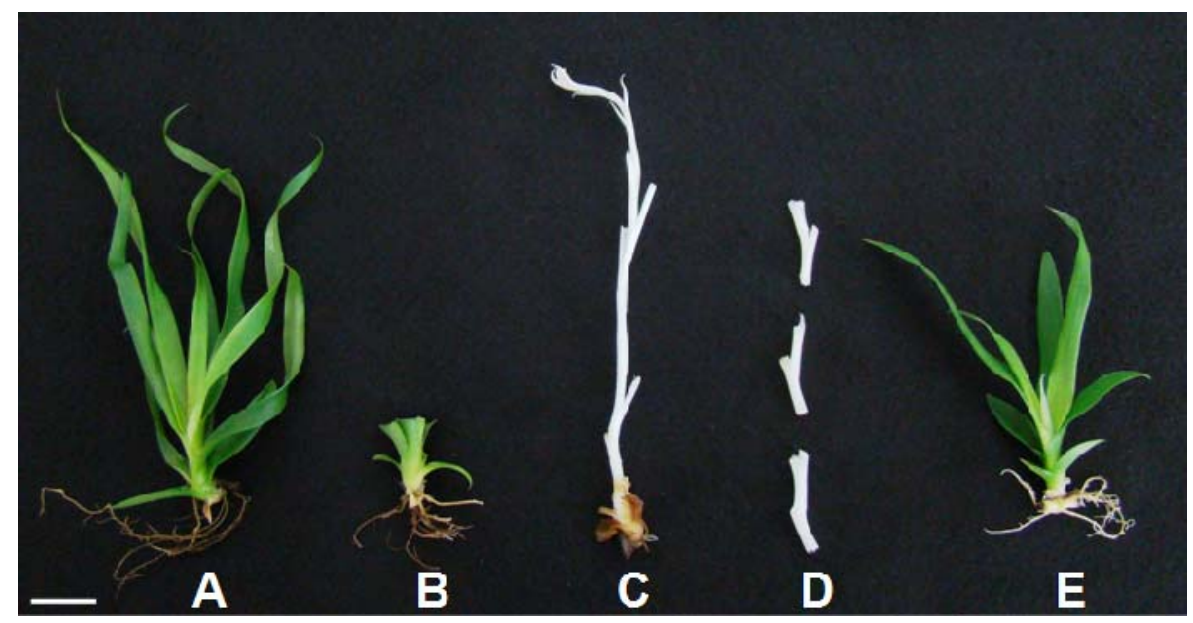

Figura 1: Seqüência de obtenção de plantas de A. comosus por cultura de segmentos nodais. (A) planta cultivada in vitro por 8 meses na presença de luz; (B) planta cujas folhas foram cortadas; (C) planta estiolada obtida após 2 meses de cultivo no escuro; (D) três segmentos nodais isolados (a partir de C); (E) planta obtida a partir do desenvolvimento da gema axilar presente no segmento nodal. Barra: $1 \mathrm{~cm}$. 
Após a obtenção das plantas, estas permaneceram durante 15 dias sob fotoperíodo de 12 horas, intensidade luminosa de $250 \mu$ moles. $\mathrm{m}^{-2} \cdot \mathrm{s}^{-1}$ e temperatura constante de $25 \pm 2^{\circ} \mathrm{C}$ para aclimatação às condições experimentais.

\section{III.2. Tratamentos para indução e reversão do CAM em abacaxizeiro}

\section{Tratamentos para indução da fotossíntese CAM em abacaxizeiro}

Para o estudo da indução do CAM em abacaxizeiro, plantas obtidas conforme descrito no item III.1 foram transferidas para meio de cultura MS líquido suplementado com 30\% de polietilenoglicol 6000 (PEG 6000), no qual permaneceram por 0, 1, 2, 3, 4, $5,6,7,8,9,10,15,20$ ou 25 dias. O objetivo da adição do PEG ao meio de cultivo foi o de promover uma redução na disponibilidade hídrica (tratamento de estresse hídrico) e, conseqüentemente, estimular a transição da fotossíntese $C_{3}$ para o CAM nas plantas de abacaxizeiro.

Como controle deste experimento, um segundo lote de plantas foi transferido para novo meio MS básico (sem a adição de PEG 6000), também na forma líquida, permanecendo pelos mesmos intervalos de tempo supracitados. Tanto o tratamento de estresse hídrico quanto o controle foram incubados sob fotoperíodo de 12 horas, intensidade luminosa de $250 \mu$ moles $\mathrm{m}^{-2} \cdot \mathrm{s}^{-1}$ e temperatura constante de $25 \pm 2^{\circ} \mathrm{C}$. Após a incubação das plantas pelos intervalos de tempo supracitados, procedeu-se a coleta de amostras de tecido foliar cerca de 1 hora antes do início e do final do período iluminado, as quais foram imediatamente congeladas em nitrogênio líquido e, em seguida, utilizadas para as análises das atividades enzimáticas ou então, estocadas a $-80^{\circ} \mathrm{C}$ até serem utilizadas nas demais análises bioquímicas. 


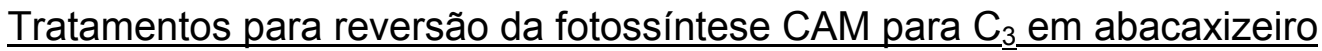

Para o estudo da reversão da fotossíntese CAM para $C_{3}$ em abacaxizeiro, plantas obtidas conforme descrito no item III. 1 foram incubadas durante 25 dias em meio de cultura MS líquido suplementado com 30\% de PEG 6000 (condição de estresse hídrico) e, posteriormente, retornadas para meio de cultura MS básico (ausência de estresse hídrico), também na forma líquida, onde permaneceram por mais $0,5,10,15$, 20 ou 25 dias, ou seja, $25^{\circ}, 30^{\circ}, 35^{\circ}, 40^{\circ}, 45^{\circ}, 50^{\circ}$ dias em termos de tempo total de tratamento. $\mathrm{O}$ objetivo de manter as plantas durante 25 dias na condição de estresse hídrico foi o de promover o estabelecimento da fotossíntese CAM nestas e, dessa forma, permitir seu eventual retorno para a fotossíntese $C_{3}$ mediante ao aumento da disponibilidade hídrica.

Como controle, um segundo lote de plantas foi transferido para novo meio MS básico na forma líquida (sem PEG), permanecendo pelos mesmos intervalos de tempo supracitados. Tanto o tratamento de reversão do CAM quanto o controle foram incubados sob fotoperíodo de 12 horas, intensidade luminosa de $250 \mu$ moles. $\mathrm{m}^{-2} \cdot \mathrm{s}^{-1} \mathrm{e}$ temperatura constante de $25 \pm 2^{\circ} \mathrm{C}$. Após a incubação das plantas pelos intervalos de tempo supracitados, procedeu-se a coleta de amostras de tecido foliar cerca de 1 hora antes do início e do final do período iluminado, as quais foram imediatamente congeladas em nitrogênio líquido e, em seguida, utilizadas para as análises das atividades enzimáticas ou então, estocadas a $-80^{\circ} \mathrm{C}$ até serem utilizadas nas demais análises bioquímicas.

\section{III.3. Tratamentos para análise da influência de hormônios, cálcio citossólico e óxido nítrico sobre a expressão do CAM em abacaxizeiro}

Plantas obtidas conforme descrito no item III.1 foram submetidas aos tratamentos relacionados na Tabela 1, com o objetivo de se caracterizar o envolvimento do abscísico 
$(\mathrm{ABA})$, citocininas, auxinas, etileno, cálcio citossólico $\left(\mathrm{Ca}^{2+}{ }_{\text {cit. }}\right)$ e óxido nítrico (NO) na regulação da expressão do CAM em $A$. comosus.

As plantas foram mantidas continuamente nos tratamentos durante 15 dias, exceto nos experimentos que empregaram os doadores de óxido nítrico (SNP, NOC9), NO gasoso ou seqüestrador de NO (cPTIO). Neste último caso, foram realizadas aplicações diárias de cada substância na concentração desejada durante os 15 dias de experimento. A renovação diária desses compostos foi realizada com o objetivo de assegurar uma maior constância em suas concentrações ao longo dos experimentos. Pelo mesmo motivo, os tratamentos com etileno ou 1-metilciclopropano (1-MCP), ambos gasosos, também foram renovados semanalmente.

As plantas dos tratamentos que empregaram compostos gasosos (NO, etileno e 1-MCP) foram mantidas em frascos lacrados com septo de borracha, sendo que as aplicações dos gases, nas concentrações e volumes desejados, foram realizadas através desses septos de borracha com auxílio de uma seringa. Anteriormente à aplicação desses compostos gasosos, os frascos contendo as plantas foram submetidos a um fluxo de ar sintético contínuo ( 3 L. $\left.\min ^{-1}\right)$ durante 5 minutos para se eliminar qualquer acúmulo destes e de outros gases no interior dos frascos. O mesmo procedimento foi realizado para as plantas que foram mantidas na condição controle. A obtenção das concentrações desejadas de etileno ou de NO em cada tratamento foi realizada por meio da diluição de misturas padrão desses compostos (mistura de calibração de 2 ppm, White Martins ${ }^{\circledR}$ ) com ar sintético. No caso do 1-MCP $\left(\right.$ Smartfresh $\left.^{\circledR}\right)$, o preparo foi realizado conforme indicado pelo fabricante.

Com exceção dos compostos gasosos, as demais substâncias utilizadas nos tratamentos (Tabela 1) foram dissolvidas em água destilada e filtradas em membrana de acetato de celulose (poros com $0.45 \mu \mathrm{m}$ de diâmetro), antes de serem adicionadas ao meio de cultura previamente autoclavado. No caso dos tratamentos com EGTA, eliminou-se o $\mathrm{CaCl}_{2}$ do meio de cultura. 
Tabela 1: Relação de substâncias utilizadas nos tratamentos para avaliação da influência de hormônios, $\mathrm{Ca}^{2+}$ citossólico e NO sobre a expressão do CAM em abacaxizeiro.

\begin{tabular}{|c|c|c|}
\hline Substância ${ }^{1}$ / Função & $\begin{array}{l}\text { Classe de sinalizador } \\
\text { analisada }\end{array}$ & $\begin{array}{c}\text { Concentrações } \\
\text { utilizadas }\end{array}$ \\
\hline Ácido abscísico (ABA) & ABA & $10 \mu \mathrm{M}^{\star}, 100 \mu \mathrm{M}^{\star \star}$ \\
\hline Fluoridona (inibidor de síntese de ácido abscísico) & ABA & $10 \mu M^{*}, 100 \mu M^{* *}$ \\
\hline Zeatina (Z) & Citocininas & $10 \mu \mathrm{M}^{\star *}$ \\
\hline Zeatina ridosídica (ZR) & Citocininas & $10 \mu \mathrm{M}^{\star \star}$ \\
\hline Isopenteniladenina (iP) & Citocininas & $10 \mu \mathrm{M}^{* *}$ \\
\hline Isopenteniladenina ribosídica (iPR) & Citocininas & $10 \mu \mathrm{M}^{\star \star}$ \\
\hline Ácido indolilacético (AIA) & Auxinas & $10 \mu M^{\star}, 100 \mu M^{\star *}$ \\
\hline NPA (inibidor de transporte polar de auxinas) & Auxinas & $10 \mu \mathrm{M}^{\star}, 100 \mu \mathrm{M}^{\star \star}$ \\
\hline Etileno & Etileno & $50 \mu \mathrm{M}^{\star}, 500 \mu \mathrm{M}^{\star \star}$ \\
\hline 1-MCP (inibidor de receptores de etileno) & Etileno & $10 \mu \mathrm{M}^{\star}, 100 \mu \mathrm{M}^{\star \star}$ \\
\hline Ionomicina (ionóforo de cálcio) & Cálcio citossólico & $1 \mu \mathrm{M}^{*}, 10 \mu \mathrm{M}^{*}$ \\
\hline EGTA (quelante de cálcio) & Cálcio citossólico & $1 \mathrm{mM}^{\star \star}, 10 \mathrm{mM}^{\star \star}$ \\
\hline Óxido nítrico (NO) & NO & $50 \mathrm{nM}^{\star}, 500 \mathrm{nM} M^{\star *}$ \\
\hline SNP (doador de NO) & NO & $1 \mu \mathrm{M}^{\star}, 10 \mu \mathrm{M}^{\star \star}$ \\
\hline $\mathrm{K}_{4} \mathrm{Fe}(\mathrm{CN})_{6}$ (controle negativo do SNP) & NO & $10 \mu \mathrm{M}^{* *}$ \\
\hline NOC9 (doador de NO) & NO & $10 \mu \mathrm{M} * \star$ \\
\hline cPTIO (seqüestrador de NO) & NO & $100 \mu \mathrm{M}^{*}, 500 \mu \mathrm{M}^{* *}$ \\
\hline \multicolumn{3}{|c|}{ 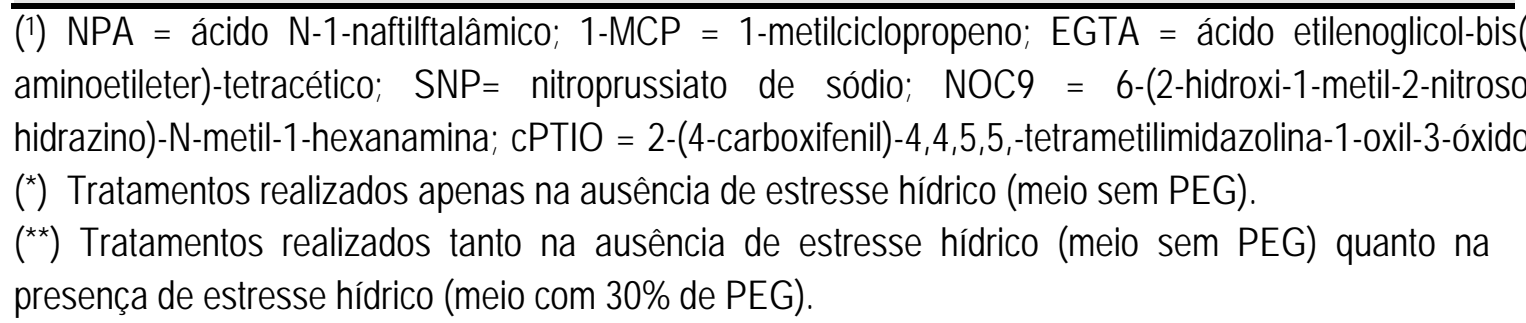 } \\
\hline
\end{tabular}

Todos os tratamento foram mantidos sob fotoperíodo de 12 horas, intensidade luminosa de $250 \mu$ moles. $\mathrm{m}^{-2} \cdot \mathrm{s}^{-1}$ e temperatura constante de $25 \pm 2^{\circ} \mathrm{C}$. Após os 15 dias de incubação, foram realizadas coletas de amostras de tecido foliar cerca de 1 hora antes do início e do final do período iluminado. Essas amostras foram imediatamente congeladas em nitrogênio líquido e, em seguida, utilizadas para as análises das atividades enzimáticas ou então, estocadas a $-80^{\circ} \mathrm{C}$ até serem utilizadas nas demais análises. 


\section{III.4. Determinação do teor relativo de água}

O teor relativo de água (TRA) presente nas folhas de abacaxizeiro foi estimado conforme BARRS \& WEATHERLEY (1962). Para tanto, as folhas das plantas submetidas aos diferentes tratamentos foram coletadas 1 hora antes do final do período iluminado, fragmentadas em pequenos segmentos (10 $\mathrm{mm}$ de comprimento e de largura) e imediatamente pesadas para a determinação da massa fresca (MF). Em seguida, os segmentos foliares foram colocados em placas de Petri na presença de água destilada e incubados a temperatura ambiente durante 6 horas. Após esse período, as superfícies dos segmentos foliares foram secas em papel de filtro e, estes foram pesados novamente para determinação da massa do tecido túrgido (MT). Após esta etapa, o material foi mantido em estufa a $60^{\circ} \mathrm{C}$ por 72 horas e, posteriormente, mantido em dessecador até atingir a temperatura ambiente e, por fim, utilizado para a determinação da matéria seca (MS).

Todas as medidas foram realizadas com a aproximação $0.1 \mathrm{mg}$ e o cálculo foi realizado conforme a fórmula abaixo:

$\operatorname{TRA}(\%)=[(\mathrm{MF}-\mathrm{MS}) /(\mathrm{MT}-\mathrm{MS})] \times 100$

\section{III.5. Determinação do acúmulo noturno de malato}

A determinação dos teores de malato foi realizada conforme método enzimático descrito por HOHORST (1965). Para tanto, amostras de tecido foliar com aproximadamente $1 \mathrm{~g}$ de massa fresca foram maceradas em nitrogênio líquido e, em seguida adicionadas de $10 \mathrm{~mL}$ de água ultrafiltrada. As amostras maceradas foram fervidas por 10 minutos e, posteriormente, centrifugadas por 10 minutos a $15.000 \mathrm{rpm}$ (Sorvall $^{\circledR}$ Instruments - rotor SM-24) para coleta do sobrenadante. O meio de reação utilizado foi composto por $50 \mathrm{mM}$ tampão glicilglicina $(\mathrm{pH} 10,0), 30 \mathrm{mM}$ de L-glutamato, 
2,7 mM de NAD ${ }^{+}, 1$ unidade de glutamato-oxalacetato transaminase (GOT, EC 2.6.1.1) e 10 unidades de L-malato desidrogenase (L-MDH, EC 1.1.1.37).

A reação foi iniciada com a adição de $100 \mu \mathrm{L}$ do sobrenadante a cada tubo. A produção de NADH foi quantificada em espectrofotômetro (340 nm) no momento inicial da reação e após 20 minutos de incubação a temperatura ambiente. Para a curva de calibração foram utilizadas concentrações entre 1 e $100 \mu \mathrm{M}$ de L-malato.

O acúmulo noturno de malato ( $\Delta$ malato) foi calculado por meio da diferença entre os teores desse ácido detectados em amostras coletadas 1 hora antes do início e 1 hora antes do final do período iluminado (POPP et al., 2003).

\section{III.6. Determinação da atividade da PEPC}

A determinação da atividade da PEPC foi realizada pelo método in vitro conforme descrito por NIEVOLA et al. (2005). Para tanto, amostras de tecido foliar (1g MF) coletadas 1 hora antes do final do período iluminado foram maceradas em nitrogênio líquido e, em seguida adicionadas de $5 \mathrm{~mL}$ do tampão de extração (pH 8), composto por $200 \mathrm{mM}$ de Tris- $\mathrm{HCl}, 10 \mathrm{mM}$ de $\mathrm{MgCl}_{2}, 5 \mathrm{mM}$ de ditiotreitol (DTT), $1 \mathrm{mM}$ de EDTA, 0.5\% $(\mathrm{m} / \mathrm{v})$ albumina bovina (BSA) e $10 \%(\mathrm{v} / \mathrm{v})$ de glicerol.

Após a homogeneização, as amostras foram centrifugadas a 15.000 rpm por 2 minutos a $4^{\circ} \mathrm{C}$ (Sorvall $^{\circledR}$ Instruments - rotor SM-24). O sobrenadante resultante foi coletado e, em seguida, utilizado no ensaio enzimático. A atividade da PEPC foi ensaiada a $30^{\circ} \mathrm{C}$ em $2 \mathrm{~mL}$ de um meio de reação contendo Tris- $\mathrm{HCl} 50 \mathrm{mM}$ (pH 8.0), 1 $\mathrm{mM}$ DTT, $10 \mathrm{mM} \mathrm{MgCl}_{2}, 10 \mathrm{mM} \mathrm{NaHCO}$, $0.2 \mathrm{mM} \mathrm{NADH}, 2 \mathrm{mM}$ fosfoenolpiruvato (PEP) e 10 unidades de L-malato desidrogenase (L-MDH).

A reação foi iniciada pela adição de $400 \mu \mathrm{L}$ do extrato. A atividade enzimática foi baseada no consumo de NADH quantificado em espectrofotômetro (340 nm) no momento inicial da reação e após 4 minutos. 


\section{III.7. Determinação da atividade da MDH}

A determinação da atividade da $\mathrm{MDH}$ foi realizada com base no método in vitro descrito por CUEVAS \& PODESTA (2000). Nesse ensaio, amostras de tecido foliar (1g MF) coletadas 1 hora antes do final do período iluminado foram maceradas em nitrogênio líquido e, em seguida adicionadas de $5 \mathrm{~mL}$ do tampão de extração (pH 8), composto por $200 \mathrm{mM}$ de Tris- $\mathrm{HCl}, 10 \mathrm{mM}$ de $\mathrm{MgCl}_{2}, 5 \mathrm{mM}$ de DTT, $1 \mathrm{mM}$ de EDTA, $0.5 \%(\mathrm{~m} / \mathrm{v})$ BSA e $10 \%(\mathrm{v} / \mathrm{v})$ de glicerol. As amostras foram submetidas a uma centrifugação de 15.000 rpm por 2 minutos a $4^{\circ} \mathrm{C}$ (Sorvall ${ }^{\circledR}$ Instruments - rotor SM-24). A atividade da $\mathrm{MDH}$ foi ensaiada no sentido da redução do oxaloacetato (OAA) em $2 \mathrm{~mL}$ de um meio de reação contendo Tris-HCl 50 mM (pH 8.0), $5 \mathrm{mM} \mathrm{MgCl}_{2}$ e $0.2 \mathrm{mM} \mathrm{NADH}$. A reação foi iniciada pela adição de 2 mM OAA e $200 \mu \mathrm{L}$ de extrato vegetal. A atividade foi baseada no consumo de NADH quantificado em espectrofotômetro (340 nm) no momento inicial da reação e após 4 minutos.

\section{III.8. Determinação da atividade da PEPCK}

A quantificação da atividade da PEPCK foi realizada com base no método in vitro descrito por LEEGOOD \& WALKER (2003). Para tanto, amostras de tecido foliar (1g MF) coletadas 1 hora antes do final do período iluminado foram macerado em nitrogênio líquido e, em seguida homogeneizadas em $5 \mathrm{~mL}$ de tampão de extração (pH 10.4) contendo $500 \mathrm{mM}$ Bicina, 1\% (m/v) PEG 6000, $50 \mathrm{mM}$ DTT e, posteriormente centrifugado a $12.000 \mathrm{rpm}$ por 5 minutos a $4^{\circ} \mathrm{C}$ (Sorvall ${ }^{\circledR}$ Instruments - rotor SM-24). A reação de carboxilação da PEPCK foi analisada em $2 \mathrm{~mL}$ de um meio de reação contendo 50 mM Hepes-KOH (pH 7.3), 5 mM PEP, 200 mM NADH, 5 mM DTT, 50 mM $\mathrm{NaHCO}_{3}, 5 \mathrm{mM} \mathrm{MnCl}, 0.5 \mathrm{mM} \mathrm{ADP}$ e 10 unidades de L-MDH. A reação foi iniciada pela adição de $400 \mu \mathrm{L}$ do extrato. A atividade foi baseada no consumo de NADH quantificado em espectrofotômetro (340 nm) no momento inicial da reação e após 4 minutos. 


\section{III.9. Quantificação dos teores endógenos de citocininas, AIA e ABA}

\section{Extração}

Amostras com $1 \mathrm{~g}$ de massa fresca, coletadas 1 hora antes do final do período iluminado, foram maceradas em nitrogênio líquido e, em seguida, homogeneizadas com $5 \mathrm{~mL}$ de uma mistura de extração contendo metanol $80 \%$ e $146 \mu \mathrm{M}$ butilhidroxitolueno (BHT). A cada amostra foram adicionados $100 \mu \mathrm{L}$ de $\mathrm{Z}$ radioativa $\left(25 \mathrm{Ci} \mathrm{mmol}^{-1}\right.$ de $\left.{ }^{3} \mathrm{H}\right] \mathrm{Z}$ - Isotope Laboratory), $1 \mu \mathrm{g}$ de $\left[{ }^{13} \mathrm{C}_{6}\right]$-AIA (Cambridge Isotopes, Inc) e 0,5 $\mu \mathrm{g}\left[{ }^{2} \mathrm{H}_{6}\right]-\mathrm{ABA}$ (Olchemin Ltd) para quantificar as perdas ocorridas durante o processo de purificação.

\section{Purificação e fracionamento dos hormônios}

Após a suspensão ficar sob agitação durante 60 horas a $4^{\circ} \mathrm{C}$, essa foi filtrada através de membranas de nitrocelulose (Millipore ${ }^{\circledR}$ ) de 0,45 e de $0,22 \mu \mathrm{m}$ de porosidade e por uma coluna Sep-Pack C-18 (Waters $\left.{ }^{\circledR}\right)$, sendo eluída com metanol 80\%.

Após a filtração, os extratos foram concentradas por evaporação à vácuo (SpeedVac Heto®, CT 100), solubilizados em $200 \mu \mathrm{L}$ de ácido fórmico $0,2 \%(\mathrm{pH} \mathrm{3,0),} \mathrm{e} \mathrm{então,}$ submetidas ao fracionamento por cromatografia líquida de alta resolução (HPLC). A separação hormonal foi realizada utilizando-se uma coluna de fase reversa C-18 (Waters ${ }^{\circledR}$, Prep Nova-Pack HR/60 A, $6 \mu \mathrm{m}, 7.8$ x $300 \mathrm{~mm}$ ) num fluxo de $3 \mathrm{~mL} . \mathrm{min}^{-1} \mathrm{com}$ um gradiente de metanol / solução de ácido fórmico $0,2 \%(\mathrm{pH} 3)$. O gradiente utilizado foi de (\% de metanol): 0-10 minutos, $18 \% ; 11-65$ minutos, $33 \% ; 65-70$ minutos, $40 \%$. Em todos os casos, a solução de ácido fórmico $0,2 \%(\mathrm{pH} 3)$ foi adicionada ao metanol para completar 100\%. A absorbância do eluente foi monitorada a $265 \mathrm{~nm}$. As frações correspondentes aos hormônios zeatina $(Z)$, zeatina ribosídica $(Z R)$, isopenteniladenina (iP), isopenteniladenina ribosídica (iPR), ácido indolilacético (AIA) e ácido abscísico (ABA), coletadas em intervalos de 30 segundos, foram concentradas à vácuo (Speed Vac Heto $\left.{ }^{\circledR}, \mathrm{CT} 100\right)$, sendo, em seguida, solubilizadas com $400 \mu \mathrm{L}$ de água adicionada de $\mathrm{NaN}_{3}(2,53 \mathrm{mM})$. 


\section{Quantificação de citocininas por ELISA}

Os teores endógenos de Z, ZR, iP e iPR foram analisados por imunoensaio (ELISA) indireto conforme descrito por PERES et al. (1997). Para tanto, as frações correspondentes a essas citocininas, separadas por HPLC, foram secas em liofilizador e, em seguida, solubilizadas com $400 \mu \mathrm{L}$ de água ultrafiltrada. Alíquotas das frações correspondentes aos tempos de retenção dos padrões de Z e ZR foram analisados com anticorpos policlonais de coelho anti-ZR. Por outro lado, as frações correspondente ao iP e iPR foram analisadas com anticorpos policlonais de coelho anti-iPR. Para a obtenção dos dados de recuperação do padrão radioativo $\left[{ }^{3} \mathrm{H}\right] \mathrm{Z}$, alíquotas de $50 \mu \mathrm{L}$ foram retiradas de cada fração correspondente ao tempo de retenção de $Z$, sendo, em seguida, adicionadas de $2 \mathrm{~mL}$ de líquido de cintilação (Packard ${ }^{\circledR}$, Ultima Gold MV) e submetidas à contagem radioativa em cintilômetro (Packard ${ }^{\circledR}$, TRI CARB 2100 TR)

Os teores de cada hormônio foram medidos quatro vezes em cada amostra e os resultados foram corrigidos, segundo os dados de recuperação do padrão radioativo $\left[{ }^{3} \mathrm{H}\right] \mathrm{Z}$ e o fator de diluição dos extratos.

\section{Quantificação de AIA e ABA por CG-EM-MSI}

Para a quantificação do AIA e ABA utilizou-se o método de cromatografia gasosa associada à espectrometria de massa, com monitoramento seletivo de íons (CG-EMMSI), conforme CHEN et al. (1988) adaptado por PURGATTO et al. (2002). As frações correspondentes ao AIA e ABA, separadas por HPLC, foram liofilizadas e em seguida solubilizadas com $300 \mu \mathrm{L}$ de metanol $100 \%$. Cada amostra foi metilada com $500 \mu \mathrm{L}$ de diazometano durante 30 minutos em um micro-tubo fechado e em seguida seca em nitrogênio gasoso.

As amostras metiladas foram solubilizadas com $50 \mu \mathrm{L}$ de acetato de etila para serem, então, analisadas em cromatógrafo a gás (CG) Hewlett-Packard modelo 6890 
acoplado a um espectômetro de massa modelo 5973. Utilizou-se uma coluna de separação HP-1701 (30 m, D.I. 0,25 mm, I.T. 0,5 $\mu \mathrm{m}$ ), tendo hélio como gás de arraste, com fluxo de $1 \mathrm{~mL} \cdot \mathrm{min}^{-1}$. As injeções foram realizadas por meio de injetor automático Hewlett-Packard modelo LS-1100 e o volume injetado de cada amostra foi de $2 \mu \mathrm{L}$, sem a utilização do divisor de amostras (splitless), com fluxo de ventilação de $20 \mathrm{~mL} \cdot \mathrm{min}^{-1}$ após 2 minutos da injeção. A coluna foi mantida a $150^{\circ} \mathrm{C}$ por 3 minutos, seguida de rampa de temperatura de $150^{\circ} \mathrm{C}$ até $200^{\circ} \mathrm{C}$ em taxa de $4^{\circ} \mathrm{C} \cdot \mathrm{min}^{-1} \mathrm{e}$, por fim, de $200^{\circ} \mathrm{C}$ até $300^{\circ} \mathrm{C}$ em taxa de $10^{\circ} \mathrm{C} \cdot \mathrm{min}^{-1}$. Foram monitorados os íons com relação massa/carga (m/z) entre 130 e 136, correspondentes ao AIA endógeno; 134, 162 e 190, correspondentes ao ABA endógeno; 136 e 195, correspondentes ao padrão interno

$\left[{ }^{13} \mathrm{C}_{6}\right]-\mathrm{AIA} ; 138,166$ e 194 correspondentes ao $\left[{ }^{2} \mathrm{H}_{6}\right]-\mathrm{ABA}$. A concentração endógena de AIA foi obtida pela comparação entre as áreas dos picos de AIA nos cromatogramas extraídos em m/z 130 e 136. Já os teores de ABA foram calculados pela relação entre as áreas dos picos nos cromatogramas extraídos em m/z 190 e 194.

\section{III.10. Quantificação da emissão de etileno}

A produção de etileno foi quantificada segundo PURGATTO et al. (2002). Para tanto, frascos contendo cerca de 30 plantas nas condições de ensaio foram, primeiramente, submetidos a um fluxo de ar sintético contínuo ( 3 L. $\min ^{-1}$ ) durante 5 minutos para se eliminar qualquer acúmulo desse gás. Esses frascos permaneceram vedados durante as últimas 6 horas do período iluminado, e em seguida foram tomadas amostras de $10 \mathrm{~mL}$ do gás contido em cada frasco para a determinação do conteúdo de etileno em cromatógrafo a gás (CG) marca Thermo Electron modelo TRACE GC Ultra com detector por ionização de chama (FID). Utilizou-se uma coluna de separação Plot RT-alumina (30 m, I.D. $0.53 \mathrm{~mm}$, filme $6 \mu \mathrm{m}$ ) e nitrogênio como gás de arraste num fluxo de $1 \mathrm{~mL} \cdot \mathrm{min}^{-1}$. Para permitir a injeção de $10 \mathrm{~mL}$ de amostra foi empregado o modo de injeção pulsed splitless, sendo que as condições de injeção foram: pressão de 20 psi por 
2 minutos e fluxo de ventilação de $5 \mathrm{~mL} \cdot \mathrm{min}^{-1}$ após 30 segundos de injeção. $\mathrm{O}$ injetor e o detector foram mantidos a $250^{\circ} \mathrm{C}$ e a coluna isotermal a $40^{\circ} \mathrm{C}$. A estimativa da produção de etileno foi realizada em relação à injeção de um padrão de 2 ppm (partes por milhão) de etileno em nitrogênio.

\section{III.11. Quantificação da emissão de NO}

A produção de NO foi quantificada por quimiluminescência, segundo método descrito por PLANCHET \& KAISER (2006). Para tanto, frascos contendo cerca de 30 plantas nas condições de ensaio foram, primeiramente, submetidos a um fluxo contínuo de nitrogênio (3 L. $\mathrm{min}^{-1}$ ) durante 20 minutos para se eliminar qualquer presença de NO como contaminante atmosférico. A seguir, manteve-se um fluxo constante de nitrogênio (1,5 L. $\left.\mathrm{min}^{-1}\right)$ no interior dos frascos com o material vegetal, sendo o gás de saída continuamente analisado por um detector de NO por quimiluminescência (CLD 88ep; Eco Physics; com limite de detecção de 20 ppt; tempo de resolução de 10 segundos). Após a quantificação da emissão de NO pelas plantas de abacaxizeiro, estas foram retiradas dos frascos de cultivo e, em seguida, a possível emissão de NO pelo próprio meio de cultivo foi acompanhada por cerca de 30 minutos. A eventual liberação de NO a partir do meio de cultivo foi descontada nos cálculos finais. Durante todas as análises, o nitrogênio foi purificado através de uma coluna preenchida com carvão ativado (1 m de comprimento e $5 \mathrm{~cm}$ de diâmetro) antes de ser injetado nos frascos contendo as amostras, garantindo, dessa forma, a ausência de NO como contaminante do próprio gás de arraste. Rotineiramente, procedeu-se a calibração do detector de quimiluminescência com uma mistura de calibração contendo NO na concentração de 100 ppb (partes por bilhão) em nitrogênio. Todas as análises foram realizadas durante as últimas 6 horas do período iluminado. 


\section{III.12. Visualização in situ da produção de NO}

Procedeu-se a coleta da porção mediana de folhas oriundas do $4^{\circ}$ e $5^{\circ}$ fitômeros

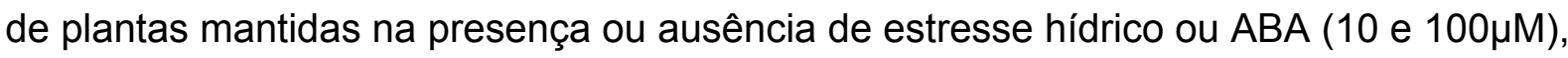
as quais foram imediatamente utilizadas para obtenção de cortes transversais finos destinados à visualização in situ da produção de NO conforme método descrito por MAGALHÃES et al. (2000).

Os cortes obtidos foram rapidamente incubados em $10 \mu \mathrm{M}$ de 4,5 diaminofluoresceína diacetato (DAF-2DA) à temperatura ambiente, na ausência de luz e sob agitação. Decorrido 30 minutos de incubação, os cortes foram lavados duas vezes com água ultrafiltrada para a retirada do excesso da substância marcadora e, em seguida, montaram-se lâminas não permanentes.

As lâminas obtidas foram imediatamente analisadas em microscópio de fluorescência Leica DMLB equipado com uma câmera digital Leica DFC 320 e filtro Leica H3 de comprimentos de onda de excitação de 450 nm e emissão de 515 nm. De modo complementar, lâminas preparadas como descrito acima também foram analisadas em Microscópio Confocal Zeiss LSM 510 Meta nas faixas de excitação de 488nm e de emissão $505-530 \mathrm{~nm}$, sendo que as imagens adquiridas foram trabalhadas utilizando-se o programa Zeiss LSM Image Bowser.

Para a realização dos controles negativos, cortes transversais de folhas de abacaxizeiro foram previamente incubados no escuro por 30 minutos em $500 \mu \mathrm{M}$ de cPTIO (2-(4-carboxifenil)-4,4,5,5,-tetrametilimidazolina-1-oxil-3-oxido), um seqüestrador de NO, e posteriormente tratados com o indicador DAF-2DA. Além disso, controles adicionais foram realizados mediante a incubação dos cortes apenas em água, por 30 minutos a temperatura ambiente, sob agitação no escuro, seguido da visualização em microscopia de fluorescência ou confocal sem a marcação com o DAF-2DA. 


\section{III.13. Amplificação, clonagem e seqüenciamento da PEPC, MDH e PEPCK de $A$. comosus}

Com o objetivo de possibilitar a quantificação dos teores de transcritos da PEPC, MDH e PEPCK ao longo dos processos de indução e de reversão do CAM em abacaxizeiro, foram realizadas, previamente, as etapas de amplificação, clonagem e obtenção das sequências parciais dos genes que codificam essas enzimas em abacaxizeiro.

\section{Extração de DNA genômico}

Para realização das reações de amplificação dos genes de interesse por PCR, fezse necessário a extração do DNA genômico de abacaxizeiro, a qual foi realizada segundo o método descrito por FULTON et al. (1995). Para tanto, cerca de $3 \mathrm{~g}$ de folhas foram, instantaneamente, congeladas em nitrogênio líquido e mantidas em $-70^{\circ} \mathrm{C}$ até serem utilizadas para a extração. O material vegetal congelado foi macerado em nitrogênio líquido juntamente com $1,5 \mathrm{~g}$ de polivinilpolipirrolidona (PVPP) até a obtenção de um pó fino. Esse pó foi transferido para tubos de centrifugação (50 mL de capacidade), aos quais foram acrescentados $18 \mathrm{~mL}$ de uma solução (tampão de extração, pH 8), composta por 100 mM de Tris-HCl, 1,4 M de NaCl, 20 mM de EDTA, $100 \mathrm{mM}$ de $\beta$-mercaptoetanol e 1\% de polivinilpirrolidona (PVP). Esses tubos foram misturados levemente por inversão e mantidos durante 2 minutos a $65^{\circ} \mathrm{C}$. Após essa incubação foram acrescentados $18 \mathrm{~mL}$ de uma mistura clorofórmio:álcool isoamílico (24:1 v/v) e após homogeneização o material foi submetido a uma centrifugação de $5.000 \mathrm{rpm}$ (Hettich Universal 30RF - rotor angular 1412) a $22^{\circ} \mathrm{C}$ por 20 minutos para a separação das fases.

A fase aquosa foi transferida para um novo tubo e onde foram adicionados $18 \mathrm{~mL}$ de uma mistura fenol:clorofórmio $(1: 1, \mathrm{v} / \mathrm{v})$. Após misturar cuidadosamente, os tubos foram centrifugados a 5.000 rpm durante 20 minutos a $22^{\circ} \mathrm{C}$ para a precipitação do DNA. Essa etapa foi repetida por duas vezes. Em seguida, coletou-se a fase aquosa, 
adicionando-se $12 \mathrm{~mL}$ de clorofórmio:álcool isoamílico $(24: 1, \mathrm{v} / \mathrm{v})$, para ser centrifugado a $5.000 \mathrm{rpm}$ durante 20 minutos a $22^{\circ} \mathrm{C}$. Novamente a fase aquosa foi transferida para um novo tubo onde foi adicionado $10 \mathrm{~mL}$ de isopropanol gelado e, então, centrifugado a $5.000 \mathrm{rpm}$ durante 20 minutos a $22^{\circ} \mathrm{C}$. Após essa centrifugação todo o sobrenadante foi descartado e, então, cada tubo foi lavado com $5 \mathrm{~mL}$ de etanol $70 \%$ e novamente centrifugado a $5.000 \mathrm{rpm}$ por 20 minutos a $22^{\circ} \mathrm{C}$.

Após essa última centrifugação, o etanol $70 \%$ foi descartado e os tubos foram secos a vácuo (Labconco ${ }^{\circledR}$, Centrovap). O DNA seco foi ressuspendido em uma mistura (tampão TE, pH 8) composta por 10 mM Tris-HCl e 1 mM de EDTA (SAMBROOK et al., 1989) durante $72 \mathrm{~h}$ a $4^{\circ} \mathrm{C}$. Para eliminar a contaminação por RNA, as amostras de DNA foram incubadas com $100 \mu \mathrm{g} / \mathrm{mL}$ de RNAaseA (Promega ${ }^{\circledR}$ ) a $42^{\circ} \mathrm{C}$ durante 1 hora. A concentração de DNA foi determinada em fluorômetro (Hoefer DyNA 200 fluorometer ${ }^{\circledR}$ ), além de ser estimada, comparando-se, em gel de agarose $1.8 \%$, as amostras com padrões de DNA de concentração conhecida.

\section{Construção de iniciadores para a PEPC, MDH e PEPCK de A. comosus}

Foram desenhados iniciadores (primers) específicos para os genes de interesse a partir de sequências de nucleotídeos de uma biblioteca de cDNA de abacaxizeiro, disponível no site do "GeneBank" (http://www.ncbi.nlm.nih.gov). Os iniciadores para o estudo da expressão do CAM em abacaxizeiro foram baseados nas seqüências de nucleotídeos da fosfoenolpiruvato carboxilase (PEPC, número de acesso: AJ312629), malato desidrogenase (MDH, número de acesso: DT336869) e fosfoenolpiruvato carboxicinase (PEPCK, número de acesso: DT335957), enquanto que o gene de expressão constitutiva escolhido foi o ribossomal 18S (Rib 18S, número de acesso: D29786). Iniciadores com aproximadamente 20 nucleotídeos foram desenhados com o auxílio do programa Primer 3, disponível no site http://fokker.wi.mit.edu/primer3. As seqüências nucleotídicas desses iniciadores encontram-se descritas na Tabela 2: 
Tabela 2: Seqüência nucleotídica dos iniciadores utilizados nas reações de amplificação por PCR.

\begin{tabular}{ll}
\hline \multicolumn{1}{c}{ Nome da proteína (sigla) } & \multicolumn{1}{c}{ Iniciadores (primers) } \\
\hline Fosfoenolpiruvato carboxilase (PEPC) & senso: 5'-CTCTTCGTGTGACAGTTC -3' \\
& anti-senso: 5'-TTCCTGGATCTCCCT-3' \\
Malato desidrogenase (MDH) & senso: 5'-TGCCCTTGAACAGTATGCAG -3' \\
& anti-senso: 5'-CCGAGTCAAGCAAGTAATGT-3' \\
Fosfoenolpiruvato carboxicinase (PEPCK) & senso: 5'- ATTGACGGTGGTTGTTATGC -3' \\
& anti-senso: 5'-GCTCATCGAAAACCACATTCT-3' \\
Ribossomal 18S (Rib 18S) & senso: 5'-AAACGGCTACCACATCCAAG-3' \\
& anti-senso: 5'-GACACAACCCAAGGTCCAA-3'
\end{tabular}

\section{$\underline{\text { Amplificação dos genes de interesse }}$}

As reações de amplificação foram realizadas em um termo-reciclador (Perkin Elmer Cetus ${ }^{\circledR}$ modelo Gene AMP PCR System 2400), utilizando-se um volume total de reação de $50 \mu \mathrm{L}$, contendo $10 \mathrm{mM}$ de cada dNTP (dATP, dCTP, dGTP, dTTP), 1,5 mM de $\mathrm{MgCl}_{2}, 5$ unidades/ $\mu \mathrm{L}$ de Taq DNA polimerase (Invitrogem ${ }^{\circledR}$ ), $1 \mathrm{mM}$ de tampão Tris$\mathrm{HCl}(\mathrm{pH} 3,8), 5 \mathrm{mM}$ de $\mathrm{KCl}, 10$ pmol de cada iniciador e $100 \mathrm{ng}$ de DNA de abacaxizeiro.

As condições de ciclo de amplificação foram $94^{\circ} \mathrm{C}$ por 30 segundos, 55 por 30 segundos, $72^{\circ} \mathrm{C}$ por 3 minutos, repetidos 35 vezes após um ciclo inicial de $94{ }^{\circ} \mathrm{C}$ por 5 minutos, finalizando com um ciclo de $72^{\circ} \mathrm{C}$ por 10 minutos. Foram utilizados $2 \mu \mathrm{L}$ do produto de reação de PCR para serem separados por eletroforese a 60 volts em gel de agarose $1.8 \%$ (p/v) em tampão TBE 1/2X (450 mM de Trisborato e 1 mM de EDTA).

O gel foi corado com brometo de etídeo $\left(5 \mu \mathrm{g} \cdot \mathrm{mL}^{-1}\right)$, visualizado por iluminação UV (302 nm) e fotografado em aparelho de fotodocumentação.

\section{Subclonagem dos fragmentos amplificados por PCR}

Para a extração das bandas do gel de agarose e subseqüente subclonagem, 20 $\mu \mathrm{L}$ do produto de reação de PCR foram fracionados por eletroforese a 60 volts em gel de agarose $1.8 \%$ (p/v) e tampão TBE 1/2X (450 mM de Trisborato e $1 \mathrm{mM}$ de EDTA). O 
gel foi corado com brometo de etídeo $\left(5 \mu \mathrm{g} \cdot \mathrm{mL}^{-1}\right)$ e visualizados por iluminação UV (302 $\mathrm{nm}$ ) durante a excisão das porções do gel que continham as bandas de interesse.

A extração do produto de PCR presente nos fragmentos do gel de agarose foi realizada utilizando-se "QUIAquick Gel Extration Kit Protocol" (Quiagen ${ }^{\circledR}$ ) de acordo com as instruções do fabricante. Após a fase de purificação, os fragmentos de DNA amplificados por PCR foram clonados em plasmídeo pGEM ${ }^{\circledR}$ (Promega $\left.{ }^{\circledR}\right)$, utilizando-se a enzima de ligação e demais reagentes fornecidos nesse kit (pGEM ${ }^{\circledR}-T$ Easy Vector System - Promega $\left.{ }^{\circledR}\right)$.

Os plasmídeos foram utilizados para a transformação de bactérias competentes conforme descrito por HANAHAN (1983). Nessa etapa, bactérias competentes foram retiradas do congelador a $-70^{\circ} \mathrm{C}$ e mantidas em gelo por 15 minutos. Transcorrido esse intervalo de tempo, adicionaram-se $2 \mu \mathrm{L}$ da mistura de ligação a um volume de $50 \mu \mathrm{L}$ de bactérias. Os micro-tubos contendo as bactérias e a mistura de ligação permaneceram no gelo durante 30 minutos e, então, foram submetidos a um choque térmico de 2 minutos a $42^{\circ} \mathrm{C}$ e rápido retorno ao gelo por mais 3 minutos.

A cada tubo foram adicionados $300 \mu \mathrm{L}$ de meio LB líquido ( $1 \%$ de triptona, $0,5 \%$ de extrato de levedura e 1\% de cloreto de sódio), seguindo-se uma incubação de 1 hora a $37^{\circ} \mathrm{C}$, sob agitação. A cultura foi inoculada em meio LB sólido ( $20 \mathrm{~g} / \mathrm{L}$ de ágar), suplementado com $100 \mu \mathrm{g} \cdot \mathrm{mL}^{-1}$ de ampicilina, $80 \mu \mathrm{g} \cdot \mathrm{mL}^{-1}$ de isopropril tio- $\beta$-Dgalactosídeo (IPTG) e $40 \mu \mathrm{g} \cdot \mathrm{mL}^{-1}$ de 5-bromo-4-cloro-3-indolil- $\beta$-D-galactosídeo (X-gal), permanecendo cerca de 16 horas a $37^{\circ} \mathrm{C}$ para a multiplicação das bactérias transformadas. Toda a manipulação foi realizada em câmara de fluxo de ar laminar, com uso de material estéril.

\section{Extração de DNA plasmidial em pequena escala (Miniprep)}

Nessa etapa experimental, as colônias de bactérias transformadas foram inoculadas em $3 \mathrm{~mL}$ de meio LB líquido contendo $100 \mu \mathrm{g} \cdot \mathrm{mL}^{-1}$ de ampicilina. Após incubação durante 16 horas a $37^{\circ} \mathrm{C}$, cerca de $1,5 \mathrm{~mL}$ da cultura foi transferida para 
micro-tubo e centrifugadas a 14.000 rpm durante 60 segundos (Hettich Universal 30RF rotor angular 1412). O sobrenadante foi descartado e mais $1,5 \mathrm{~mL}$ da cultura foi adicionado ao mesmo tubo e centrifugado novamente. O sobrenadante foi descartado e as bactérias foram retomadas em $300 \mu \mathrm{L}$ da solução P1 (50 mM de Tris pH 8,0; 10 mM de EDTA e $100 \mu \mathrm{g} / \mathrm{mL}$ de RNaseA). Em seguida, foram adicionados $300 \mu \mathrm{L}$ da solução P2 (200mM de NaOH e 1\% de SDS). O tubo foi agitado por inversão suave e incubado a temperatura ambiente durante 5 minutos. Após esse período de incubação, foram adicionados $300 \mu \mathrm{L}$ de acetato de potássio $3 \mathrm{M}(\mathrm{pH}$ 5,5) e o tubo foi agitado por inversão suave logo após a adição da solução. Em seguida, a amostra foi centrifugada a 14.000 rpm durante 20 minutos a $4^{\circ} \mathrm{C}$ e o sobrenadante foi coletado e transferido para um novo tubo. O sobrenadante coletado no novo tubo foi adicionado de $400 \mu \mathrm{L}$ de isopropanol e centrifugado a $14.000 \mathrm{rpm}$ durante 5 minutos a $4^{\circ} \mathrm{C}$, para a precipitação do DNA. O sobrenadante foi descartado e o precipitado foi seco em liofilizador. Depois de seco, o DNA foi ressuspendido em $50 \mu \mathrm{L}$ de tampão TE $1 \mathrm{X}(10 \mathrm{mM}$ de Tris $\mathrm{pH}$ 8,0 e $1 \mathrm{mM}$ de EDTA). Uma alíquota do DNA plasmidial obtido foi separada para a realização das reações de seqüenciamento e o restante foi armazenado $\mathrm{a}-80^{\circ} \mathrm{C}$.

\section{Seqüenciamento dos fragmentos de DNA amplificados por PCR}

O seqüenciamento das amostras de DNA foi realizado utilizando-se $600 \mathrm{ng}$ de DNA plasmidial purificado contendo os fragmentos de interesse. Ao menos 3 colônias de cada fragmento clonado foram selecionadas para seqüenciamento. Para tanto, utilizouse um seqüenciador automático (ABI Prism, 310 Genetic Analyser Perkin Elmer Applied Biosystems) e o "Kit" de sequenciamento de DNA (BigDye ${ }^{\mathrm{TM}}$ Terminator Cycle Sequencing Ready Reaction, P.E. Applied Biosystems), de acordo com metodologia descrita pelo fabricante.

Após o seqüenciamento, foi realizado o alinhamento das seqüências obtidas utilizando-se o programa "Sequence Navigator" (ABI Prism, Perkin Elmer) e "Phred/Phrap Consed". Análises posteriores foram efetuadas através de consulta a 
banco de dados (National Center for Biothecnology Information / EUA), onde foram realizadas as comparações das seqüências de nucleotídeos utilizando-se o programa BLASTn (http://www.ncbi.nlm.nih.gov).

\section{III.14. Análises dos teores de transcritos da PEPC, MDH e PEPCK}

As análises dos teores de transcritos da PEPC, MDH e PEPCK foram realizadas por meio das técnicas de slot blot ou Northern blot. A primeira etapa para possibilitar essas análises consistiu na extração e quantificação do RNA total das amostras coletas durante os períodos de indução ou de reversão do CAM em abacaxizeiro.

\section{Extração de RNA total}

Durante a extração do RNA, bem como para as etapas posteriores, foram tomados cuidados especiais a fim de garantir a integridade do mesmo. Para tanto, todos os utensílios utilizados foram previamente tratados com água ultrapurificada adicionada de $0.01 \%$ de dietilpirocarbonato (DEPC), um composto que inibe a ação das RNases, e submetidos à esterilização em autoclave por 30 minutos Todas as soluções utilizadas foram preparadas com água ultrafiltrada previamente tratadas com DEPC.

Amostras de tecido foliar (1g MF) foram coletadas 1 hora antes do final do período iluminado, maceradas em nitrogênio líquido, adicionadas de $5 \mathrm{~mL}$ de $\operatorname{TLE}(0,2 \mathrm{M}$ Tris- $\mathrm{HCl}$ - pH 7.5; 0.1M LiCl; 5mM EDTA; 10\% SDS), seguindo-se de agitação em vórtex por 30 segundos. Após 5 minutos de incubação a temperatura ambiente, foram adicionados $5 \mathrm{~mL}$ da mistura fenol:clorofórmio:álcool isoamílico (25:24:1, v/v/v), seguindo-se de agitação em vórtex por 30 segundos e uma centrifugação a 8.000 rpm por 20 minutos a $4^{\circ} \mathrm{C}$ (Sorvall ${ }^{\circledR}$ Instruments - rotor angular SS-34). A extração com fenol foi repetida por mais duas vezes. A fase aquosa foi transferida para um novo tudo e adicionada de 1 volume de $\mathrm{LiCl} 6 \mathrm{M}$, seguindo-se da agitação por 30 segundos em vórtex. A amostra foi mantida por cerca de 12 horas em gelo e a $4^{\circ} \mathrm{C}$. 
Após essa etapa, a amostra foi submetida a uma centrifugação a 8.000 rpm por 10 minutos a $4^{\circ} \mathrm{C}$, sendo que o sobrenadante foi descartado e o precipitado solubilizado em $5 \mathrm{~mL}$ de $\mathrm{LiCl}$ 3M. A amostra foi então novamente centrifugada a 8.000 rpm por 10 minutos a $4^{\circ} \mathrm{C}$. O sobrenadante foi descartado e o precipitado foi solubilizado em $900 \mu \mathrm{L}$ de água ultrapurificada esterilizada tratada com DEPC $0.01 \%$.

O RNA foi precipitado através da adição de $100 \mu \mathrm{L}$ de acetado de sódio $3 \mathrm{M}$ e 2 $\mathrm{mL}$ de etanol absoluto gelado e, em seguida, deixado a $-80^{\circ} \mathrm{C}$ por 30 minutos. Após esse período, as amostras foram centrifugadas a $8.000 \mathrm{rpm}$ por 15 minutos a $4^{\circ} \mathrm{C}$. O sobrenadante foi descartado, o precipitado foi lavado com $5 \mathrm{~mL}$ de etanol $70 \%$ e deixado para secar a temperatura ambiente. Em seguida, o precipitado foi solubilizado em $50 \mu \mathrm{L}$ de água tratada com DEPC por meio de incubação a $55^{\circ} \mathrm{C}$ por 10 minutos. As amostras extraídas foram analisadas quanto à integridade do RNA por meio de eletroforese em gel de agarose a 1,8\% em tampão TBE 1/2X. Além disso, a concentração e pureza do RNA extraído foram analisadas através da leitura da densidade óptica em espectrofotômetro (ND-1000 - NanoDrop ${ }^{\circledR}$ ) à razão 260/280 nm. Em seguida, as amostras foram armazenadas a $-80{ }^{\circ} \mathrm{C}$, onde permaneceram até o momento de sua utilização nas análises dos teores de transcritos dos genes de interesse.

\section{$\underline{\text { Slot blot }}$}

O ensaio de slot blot foi realizado conforme descrito por SAMBROOK et al. (1989). Para tanto, alíquotas contendo $10 \mu \mathrm{g}$ de RNA total foram ajustadas para $50 \mu \mathrm{L}$ com água tratada com DEPC e, em seguida, submetidas à desnaturação por meio de sua incubação a $60^{\circ} \mathrm{C}$ por 30 minutos na presença de $30 \mu \mathrm{L}$ de SSC $20 X$ ( $3 \mathrm{M}$ de cloreto de sódio e $300 \mathrm{mM}$ de citrato de sódio) e $20 \mu \mathrm{L}$ de formaldeído 37\%. Após a desnaturação, as amostras de RNA foram mantidas em gelo até o momento de sua transferência para uma membrana de náilon. 
Para tanto, uma membrana de náilon (Hybond ${ }^{\mathrm{TM}}-\mathrm{N}$, Amersham Biosciences), previamente umedecida em SSC 10X (1,5 M de cloreto de sódio e $150 \mathrm{mM}$ de citrato de sódio), foi depositada no aparato de transferência e, em seguida, lavada duas vezes com SSC 10X sob vácuo. Em seguida, as amostras de RNA desnaturado foram transferidas à vácuo para membrana de náilon, as quais foram lavadas novamente com SSC 10X sob vácuo. Ao final, a membrana foi seca à temperatura ambiente e o RNA fixado a $80^{\circ} \mathrm{C}$ por 2 horas. A membrana foi mantida em local seco até ser utilizada para a hibridação com as sondas de interesse.

\section{Northern blot}

O ensaio de Northern blot foi realizado conforme descrito por SAMBROOK et al. (1989). Para tanto, alíquotas contendo $10 \mu \mathrm{g}$ de RNA total foram fracionadas por meio de eletroforese em gel de agarose-formaldeído $(1,5 \%$ de agarose e $6,7 \%$ de formaldeído) e tampão MOPS 1X (20 mM de MOPS - pH 7.0; $50 \mathrm{mM}$ de acetato de sódio e $1 \mathrm{mM}$ de EDTA). Após a eletroforese, o gel foi lavado três vezes por 10 minutos com água e uma vez durante 40 minutos com SSC 10X (1,5 M de cloreto de sódio e 150 $\mathrm{mM}$ de citrato de sódio), sendo então colocado em aparato de transferência. Uma membrana de náilon, previamente umedecida em SSC 10X, foi depositada sobre o gel, seguida da transferência por capilaridade em SSC 10X durante 20 horas. Ao final, a membrana foi seca à temperatura ambiente e o RNA fixado a $80^{\circ} \mathrm{C}$ por 2 horas. $\mathrm{A}$ membrana foi mantida em local seco até ser utilizada para a hibridação com as sondas de interesse.

\section{Hibridação das membranas de slot blot e Northern blot}

Nas hibridações moleculares, foram utilizadas sondas de DNA marcadas $\left({ }^{32} \mathrm{P}\right)$, construídas com base nas seqüências nucleotídicas dos genes de interesse clonados de abacaxizeiro. A marcação das sondas foi realizada por meio da incorporação de $\left(\alpha-{ }^{32} P\right)$ dNTP utilizando-se Randon Primers DNA Labeling System (Gibco BRL ${ }^{\circledR}$ ). A hibridação 
foi conduzida mantendo-se a membrana na solução de hibridação (500 mM de tampão fosfato $\mathrm{pH} 7,4 ; 7 \%$ de dodecil sulfato de sódio e $1 \mathrm{mM}$ de EDTA) por um período de 2 horas a $65^{\circ} \mathrm{C}$ e adicionando-se, em seguida, a sonda de DNA marcada para uma incubação de $16-24$ horas a $65^{\circ} \mathrm{C}$. A primeira lavagem da membrana foi realizada com SSC 2X (300 mM de cloreto de sódio e $30 \mathrm{mM}$ de citrato de sódio) à temperatura ambiente por 5 minutos, seguido de duas lavagens com SSC 2 X e $20 \%$ de dodecilsulfato de sódio (SDS) a $65^{\circ} \mathrm{C}$ por 15 minutos e uma lavagem final com SSC $2 X$ à temperatura ambiente por 5 minutos. Após as lavagens, um filme de raio $\mathrm{X}$ foi depositado sobre a membrana, sendo esse conjunto mantido a $-70^{\circ} \mathrm{C}$, pelo tempo necessário para a impressão do filme. A revelação do filme foi realizada em tanque de revelação em sala escura, utilizando revelador e secador Kodak ${ }^{\circledR}$.

\section{Quantificação do sinal de hibridação do slot blot ou Northern blot}

Após a hibridação com a sonda do gene de interesse (PEPC, MDH ou PEPCK), esta foi removida das membranas através de lavagem com solução fervente de SDS $0,1 \%$. Em seguida, as membranas lavadas foram hibridadas com sonda para o ribossomal $18 \mathrm{~S}$ (Rib 18S) de $A$. comosus. Os dados foram normalizados através da divisão dos sinais de hibridização do gene de interesse pelos respectivos sinais de hibridização do 18S. Para análises dos resultados, o valor do sinal de hibridação no tempo 0 de cada experimento foi arbitrariamente considerado igual a 1 . O sinal de hibridização de cada banda foi quantificado utilizando-se o programa ImageJ $1.38(\mathrm{NIH})$. 


\section{RESULTADOS}

\section{IV.1. Indução da fotossíntese CAM em plantas $C_{3}$ de abacaxizeiro}

Inicialmente, o tipo de comportamento fotossintético $\left(\mathrm{C}_{3}\right.$ ou CAM) apresentado por plantas de abacaxizeiro submetidas ao tratamento de estresse hídrico ou mantidas na condição controle foi analisado por meio da determinação do acúmulo noturno de malato ( $\Delta$ malato) e dos teores de atividade de três enzimas chaves para o estabelecimento da fotossíntese CAM (PEPC, MDH e PEPCK).

Como mostra a Figura 2, as plantas mantidas na condição controle (sem PEG) apresentaram valores reduzidos de $\Delta$ malato associados a baixos teores de atividade da PEPC, MDH e PEPCK durante todo o período analisado, indicando a ocorrência de fotossíntese do tipo $\mathrm{C}_{3}$.

Em contrapartida, as plantas de abacaxizeiro submetidas ao tratamento de estresse hídrico (30\% de PEG) apresentaram um aumento progressivo tanto no acúmulo noturno de ácido málico quanto nas atividades enzimáticas (Figura 2), indicando uma mudança do comportamento fotossintético $\mathrm{C}_{3}$ para o CAM. Os teores de $\triangle$ malato e as atividades da PEPC e PEPCK das plantas expostas ao estresse hídrico foram significativamente superiores aos das plantas controle a partir do $8^{\circ}$ dia de tratamento (Figuras 2A, B e D, respectivamente). A atividade da $\mathrm{MDH}$, por sua vez, apresentou aumentos significativos já a partir do $7^{\circ}$ dia de incubação das plantas na condição de estresse hídrico (Figura 2C).

Também foi observada uma tendência de estabilização nos teores de acúmulo noturno de malato e atividades enzimáticas a partir do $15^{\circ}$ dia de exposição das plantas ao tratamento de estresse hídrico (Figura 2), sugerindo que a partir desse momento o comportamento CAM já teria se estabelecido plenamente. 

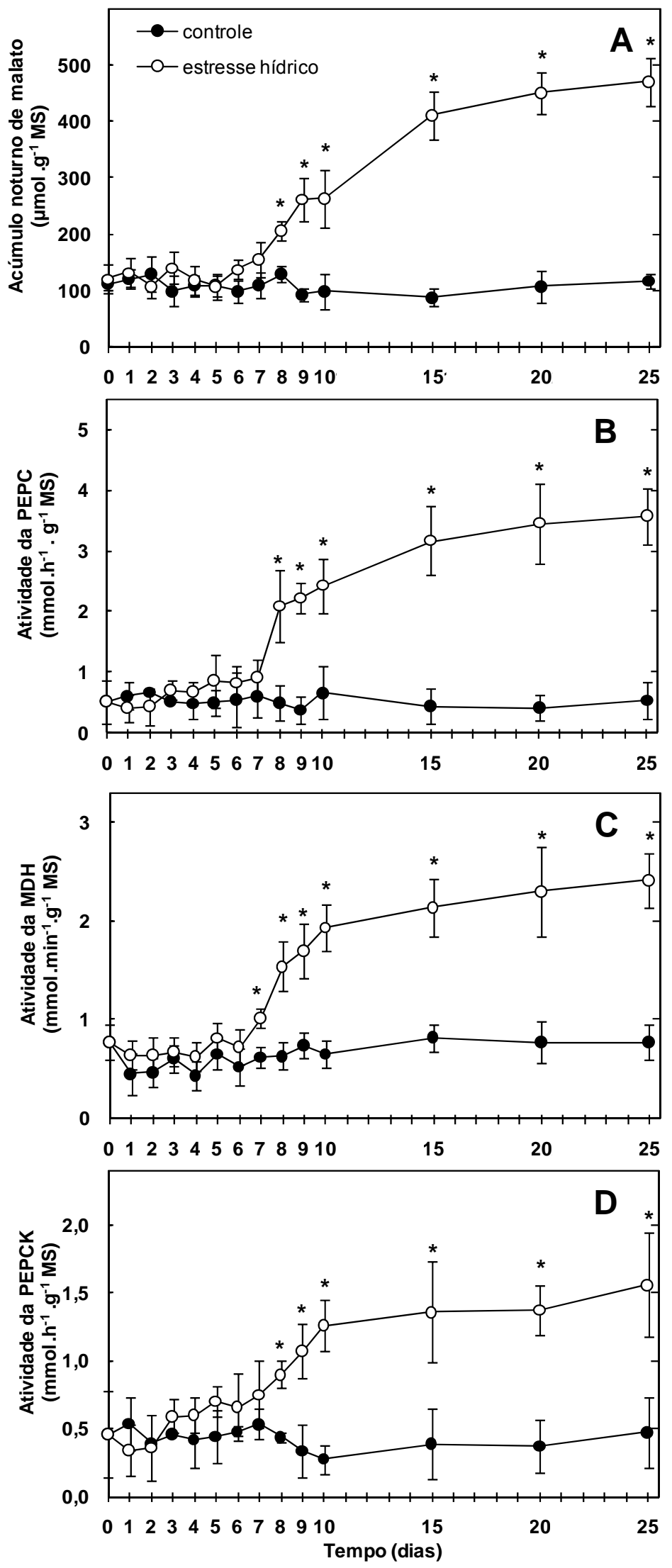

Figura 2. Acúmulo noturno de malato (A) e atividades das enzimas PEPC (B), MDH (C) e PEPCK (D) em folhas de abacaxizeiro durante a indução da fotossíntese CAM por estresse hídrico. Os valores mostrados representam a média \pm DP de experimentos realizados em triplicata. ${ }^{*}, P<0,05$, Teste $t$, representando diferença significativa entre a condição controle e o tratamento de estresse hídrico. 
Tendo em vista que a expressão de genes que codificam enzimas características do comportamento CAM representa um dos eventos mais rápidos durante a indução desse tipo de comportamento fotossintético (CUSHMAN \& BOHNERT, 1997, 1999), este trabalho também buscou analisar os teores de transcritos da PEPC, MDH e PEPCK com o intuito de estabelecer com maior precisão o início da transição da fotossíntese $C_{3}$ para CAM em abacaxizeiro. Para permitir tais análises foram realizadas as etapas de amplificação, clonagem e obtenção das seqüências parciais dos genes que codificam as enzimas supracitadas em $A$. comosus.

Primeiramente, foram conduzidas reações de amplificação por PCR a partir do DNA genômico de abacaxizeiro utilizando iniciadores específicos para a PEPC, a MDH ou a PEPCK dessa espécie. Como mostra a Figura 3, essas reações de PCR resultaram na amplificação de fragmentos de DNA que formaram bandas únicas bem definidas quando fracionados em gel de agarose. Os produtos de amplificação obtidos com os iniciadores desenhados para a PEPC apresentaram uma massa molecular de aproximadamente 800 pares de bases $(\mathrm{pb})$. Por outro lado, as reações de PCR que empregaram os iniciadores desenhados para a PEPCK e MDH produziram fragmentos com massa molecular de cerca de 200 e 600 pb, respectivamente (Figura 3).

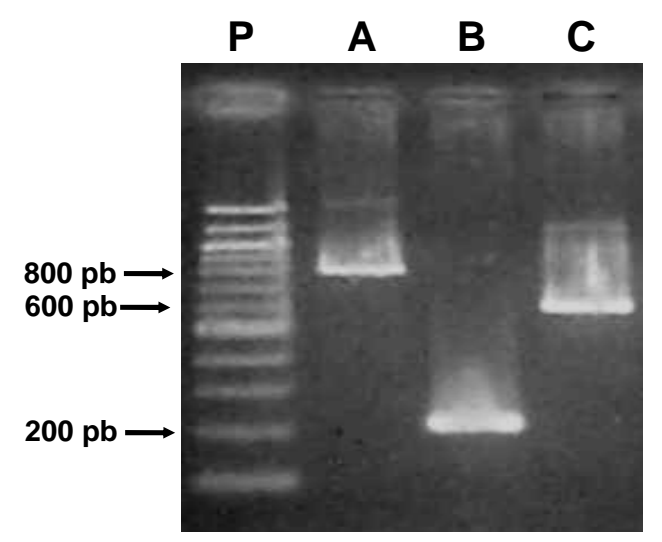

Figura 3. Fragmentos amplificados a partir de reações de PCR com DNA genômico de abacaxizeiro e iniciadores construídos para a PEPC (A), PEPCK (B) e MDH (C) separados por eletroforese em gel de agarose a $1.8 \%$. Setas pretas indicam o tamanho molecular aproximado dos fragmentos obtidos. $\grave{A}$ esquerda, marcador de massa molecular de $100 \mathrm{pb}(\mathbf{P})$. 
Os fragmentos de DNA obtidos por PCR foram isolados, quantificados, ligados à vetores e, em seguida subclonados em bactérias competentes. Posteriormente, procedeu-se a seleção das colônias de bactérias transformadas, a extração do DNA plasmidial e o seqüenciamento de nucleotídeos dos insertos clonados. Com base na análise das seqüências obtidas (Anexo I), foi possível concluir que os fragmentos amplificados nas reações de PCR realmente correspondem aos genes de interesse.

Após essa etapa preliminar, foram iniciadas as quantificações dos teores de transcritos dessas três enzimas durante o período que abrange a indução do CAM em abacaxizeiro. As análises realizadas por meio da técnica de slot blot revelaram que já a partir do $5^{\circ}$ dia de tratamento os teores de transcritos da PEPC e MDH detectados nas plantas expostas ao estresse hídrico foram significativamente superiores aos das plantas mantidas na condição controle (Figuras 4 e 5).

Por outro lado, os teores de expressão do RNAm da PEPCK observados nas plantas submetidas ao estresse hídrico foram superiores aos das plantas controle apenas a partir do $6^{\circ}$ dia de tratamento (Figura 6). Além disso, foi constatado que períodos de exposição ao estresse hídrico superiores a 15 dias não resultaram em aumentos adicionais nos teores de expressão do RNAm das três enzimas analisadas (Figuras 4, 5 e 6).

Como mostra a Figura 7, os níveis de expressão do RNAm da PEPC durante a indução do CAM também foram quantificados por meio da técnica de Northern blot. Os resultados dessas análises foram bastante similares àqueles obtidos anteriormente através da técnica de slot blot (Figura 4), uma vez que demonstraram aumentos significativos nos teores de transcritos da PEPC a partir do $6^{\circ}$ dia de exposição das plantas ao estresse hídrico (Figura 7). 

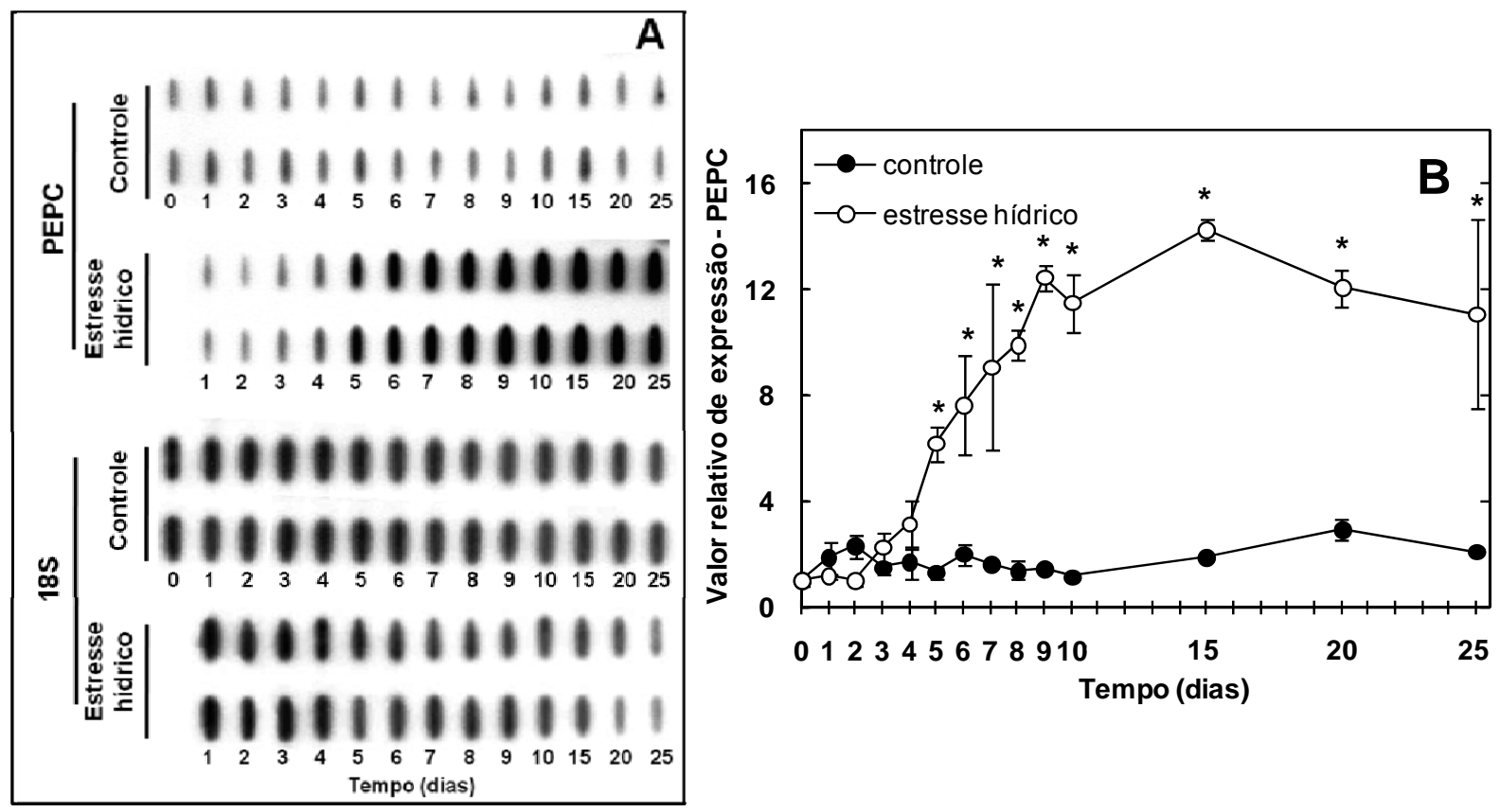

Figura 4. Teores de transcritos da PEPC em folhas de abacaxizeiro durante a indução do CAM por estresse hídrico. A) Membranas de slot blot hibridadas com sonda para a PEPC ou para o ribossomo 18S (Rib18S) de abacaxizeiro. B) Gráfico mostrando o valor relativo da expressão da PEPC. Os teores de transcritos presentes no tempo 0 foram determinados como 1 . Os valores mostrados representam a média \pm DP de experimentos realizados em duplicata. *, $\mathrm{P}<0,05$, Teste $\mathrm{t}$, representando diferença significativa entre a condição controle e o tratamento de estresse hídrico.

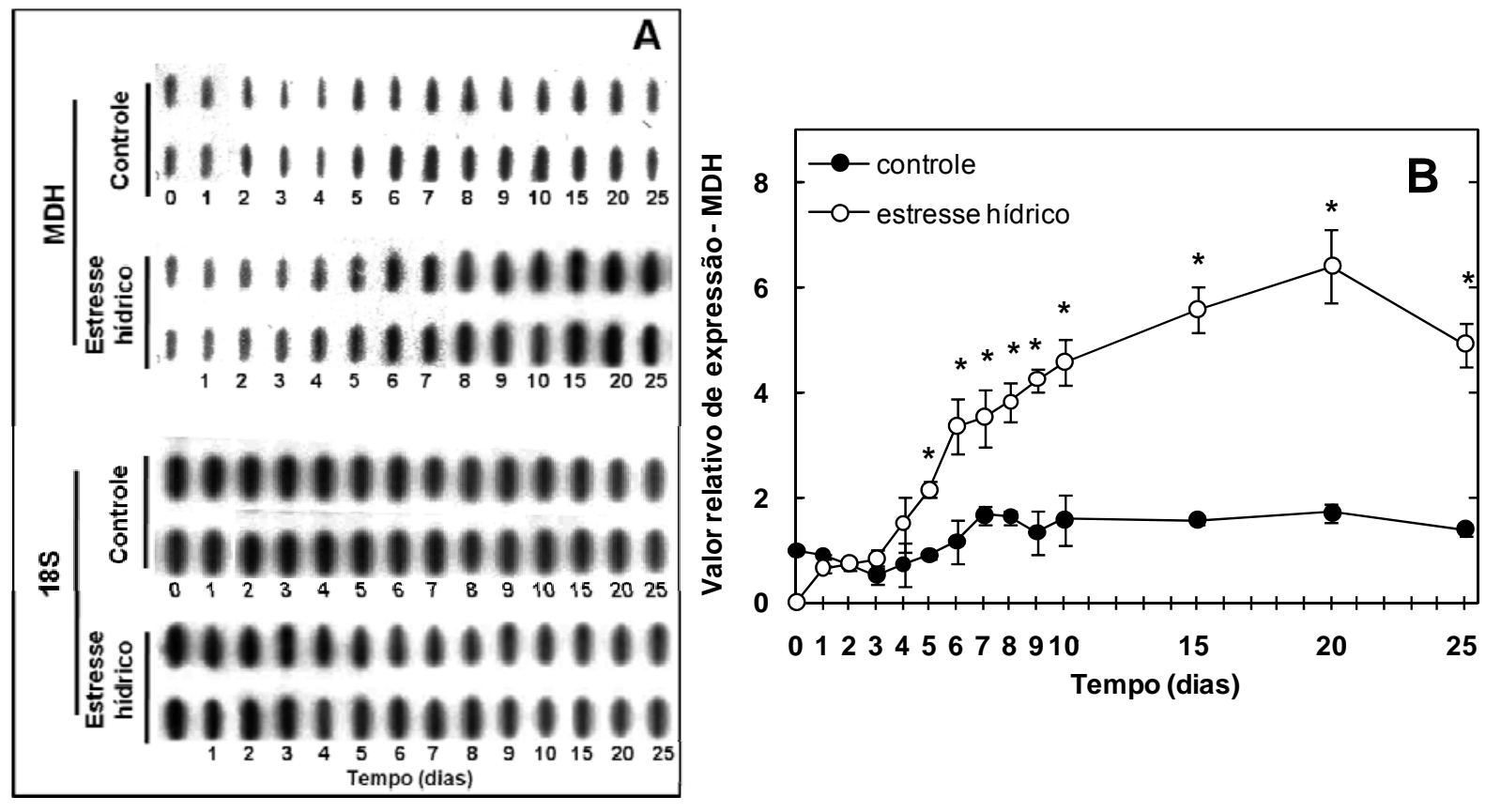

Figura 5. Teores de transcritos da MDH em folhas de abacaxizeiro durante a indução do CAM por estresse hídrico. A) Membranas de slot blot hibridadas com sonda para a MDH ou para ou para o ribossomo $18 \mathrm{~S}$ (Rib18S) de abacaxizeiro. B) Gráfico mostrando o valor relativo da expressão da MDH. Os teores de transcritos presentes no tempo 0 foram determinados como 1 . Os valores mostrados representam a média \pm DP de experimentos realizados em duplicata. ${ }^{*}, \mathrm{P}<0,05$, Teste $\mathrm{t}$, representando diferença significativa entre a condição controle e o tratamento de estresse hídrico. 


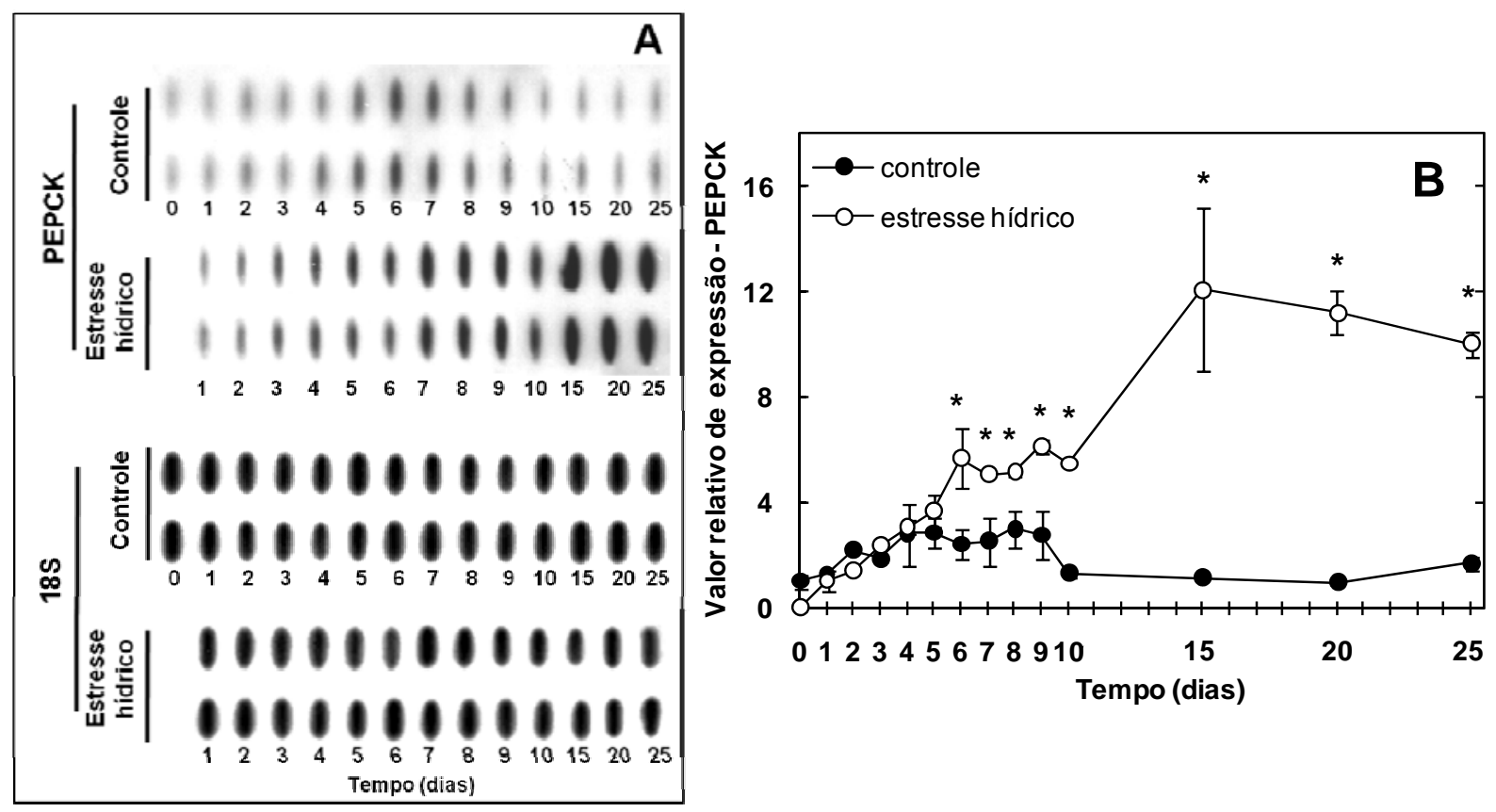

Figura 6. Teores de transcritos da PEPCK em folhas de abacaxizeiro durante a indução do CAM por estresse hídrico. A) Membranas de slot blot hibridadas com sonda para a PEPCK ou para o ribossomo $18 \mathrm{~S}$ (Rib18S) de abacaxizeiro. B) Gráfico mostrando o valor relativo da expressão da PEPCK. Os teores de transcritos presentes no tempo 0 foram determinados como 1 . Os valores mostrados representam a média \pm DP de experimentos realizados em duplicata. ${ }^{*}, P<0,05$, Teste $t$, representando diferença significativa entre a condição controle e o tratamento de estresse hídrico.
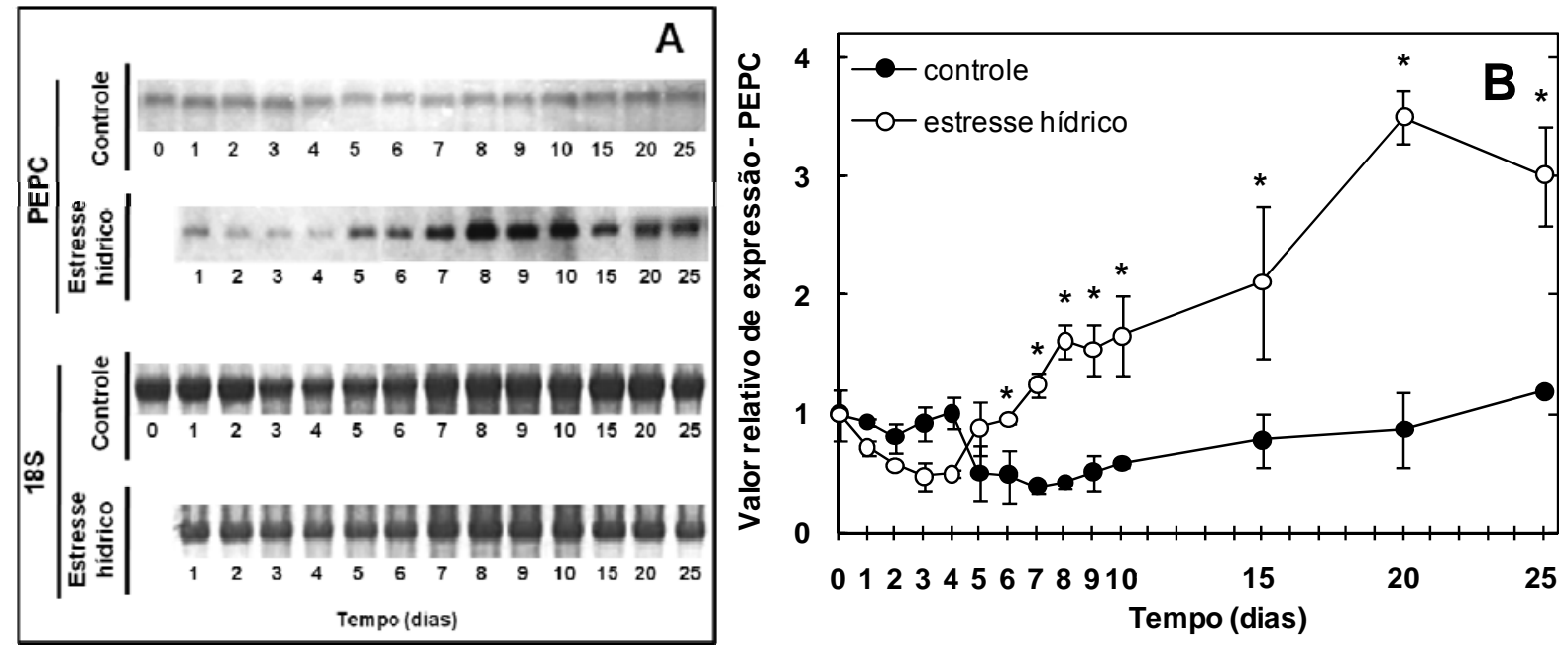

Figura 7. Teores de transcritos da PEPC em folhas de abacaxizeiro durante a indução do CAM por estresse hídrico. A) Membranas de Northern blot hibridadas com sonda para a PEPC ou para o ribossomo $18 \mathrm{~S}$ (Rib18S) de abacaxizeiro. B) Gráfico mostrando o valor relativo da expressão da PEPC. Os teores de transcritos presentes no tempo 0 foram determinados como 1 . Os valores mostrados representam a média \pm DP de experimentos realizados em duplicata. ${ }^{*}, \mathrm{P}<0,05$, Teste $t$, representando diferença significativa entre a condição controle e 0 tratamento de estresse hídrico. 
As plantas controle, por sua vez, apresentaram teores de expressão do RNAm da PEPC, MDH e PEPCK bastante reduzidos, os quais se mantiveram relativamente estáveis durante todo o período analisado (Figuras 4 a 7 ).

Tais resultados permitiram caracterizar o início da indução do CAM em abacaxizeiro entre $05^{\circ}$ e $6^{\circ}$ dia de exposição das plantas à condição de estresse hídrico. Além disso, tais análises apresentam evidências adicionais de que a partir do $15^{\circ}$ de tratamento com estresse hídrico já houve o estabelecimento pleno da fotossíntese CAM nessa bromélia.

Como mostra a Figura 8 , os teores relativos de água presentes nos tecidos foliares de $A$. comosus também foram acompanhados durante o período que abrange a indução do CAM nessa espécie.

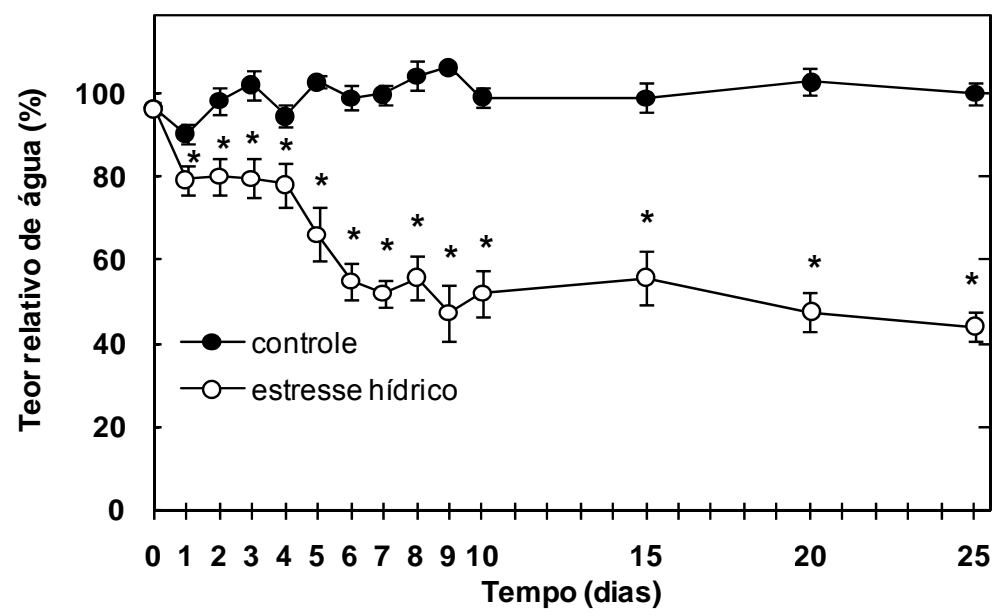

Figura 8. Teor relativo de água em folhas de abacaxizeiro durante a indução do CAM por estresse hídrico. Os valores mostrados representam a média \pm DP de 15 medições. *, $\mathrm{P}<0,05$, Teste $t$, representando diferença significativa entre a condição controle e o tratamento de estresse hídrico.

Foi verificado que os tecidos foliares de abacaxizeiro apresentaram reduções significativas em seus teores relativos de água já partir do $1^{\circ}$ dia de incubação das plantas na condição de estresse hídrico (Figura 8). Além disso, constatou-se que grande parte da redução no conteúdo hídrico das folhas de abacaxizeiro esteve compreendida entre $04^{\circ}$ e $6^{\circ}$ dia de exposição das plantas ao estresse hídrico. No $6^{\circ}$ dia de 
tratamento, o conteúdo hídrico foliar das plantas expostas ao estresse hídrico foi cerca de $55 \%$ inferior ao das plantas controle. Após a redução nos teores de água das folhas de abacaxizeiro (Figura $8,4^{\circ}-6^{\circ}$ dia), estes permaneceram praticamente constantes durante o restante do período de tratamento com estresse hídrico.

Por outro lado, as plantas mantidas na condição controle não apresentaram variações pronunciadas no teor relativo de água de suas folhas durante todo o período analisado (Figura 8).

\section{IV.2. Reversão da fotossíntese CAM para $C_{3}$ em abacaxizeiro.}

A capacidade de reversão da fotossíntese CAM para $C_{3}$ em abacaxizeiro foi avaliada por meio do acompanhamento do $\Delta$ malato e dos teores de atividade da PEPC, MDH e PEPCK em plantas mantidas durante 25 dias em estresse hídrico e, em seguida, retornadas para a condição controle por mais $0,5,10,15,20$ e 25 dias.

Como mostra a Figura 9, as plantas submetidas ao tratamento de reversão do CAM apresentaram uma redução progressiva nos teores de $\Delta$ malato e nas atividades enzimáticas até o $20^{\circ}$ dia de experimento, indicando a ocorrência de uma diminuição gradativa na expressão do CAM. A partir do $15^{\circ}$ dia, as plantas do tratamento de reversão do CAM apresentaram valores de $\Delta$ malato e de atividade da PEPC similares aos detectados nas plantas controle (Figura 9A e B). Por outro lado, os teores de atividade da MDH e da PEPCK foram similares entre os dois tratamentos apenas a partir do $20^{\circ}$ dia de experimento (Figura 9C e D). 

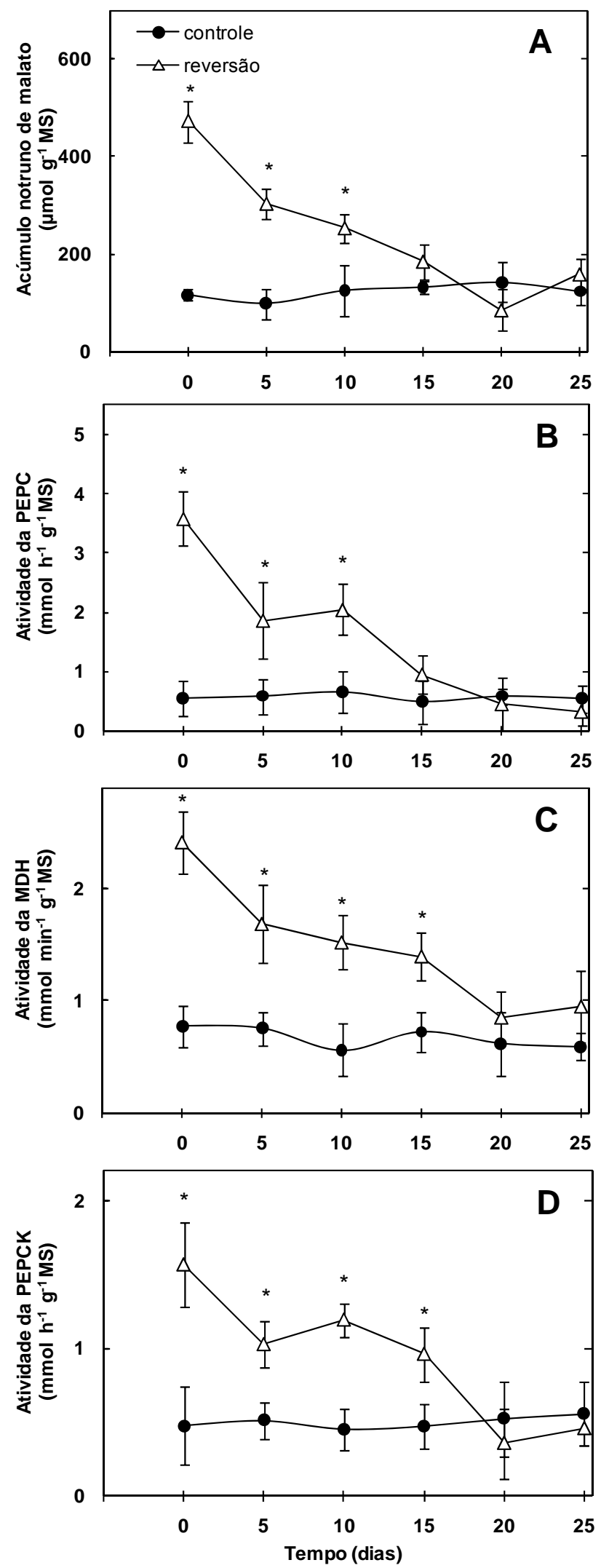

Figura 9. Acúmulo noturno de malato (A) e atividades das enzimas PEPC (B), MDH (C) e PEPCK (D) em folhas de abacaxizeiro durante a reversão da fotossíntese CAM para $C_{3}$. As plantas do tratamento de reversão do CAM foram mantidas durante 25 dias em estresse hídrico e, em seguida, transferidas para a condição controle, na qual permaneceram por mais $0,5,10,15,20$ e 25 dias. Os valores mostrados são a média \pm DP de experimentos realizados em triplicata. *, $P<0,05$, Teste $t$, representando diferença significativa entre a condição controle e o tratamento de reversão do CAM. 
Também foram realizadas análises da expressão do RNAm da PEPC, MDH e PEPCK durante o período que compreende a reversão da fotossíntese CAM em abacaxizeiro (Figuras 10, 11 e 12). Verificou-se que as plantas submetidas ao tratamento de reversão do CAM apresentaram uma redução gradativa nos teores de transcritos dessas três enzimas até o $20^{\circ}$ dia do experimento (Figuras 10, 11 e 12). A partir do $20^{\circ}$ dia, os teores de transcritos da PEPC e $\mathrm{MDH}$ foram similares entre as plantas do tratamento de reversão do CAM e aquelas mantidas continuamente na condição controle (Figuras 10 e 11). Por outro lado, apesar de ter ocorrido uma redução considerável nos teores de transcritos da PEPCK também no $20^{\circ}$ dia do tratamento de reversão do CAM, estes ainda permaneceram mais elevados do que os da condição controle (Figura 12). As plantas mantidas continuamente na condição controle não apresentam variações proeminentes nos teores de $\Delta$ malato, expressão do RNAm e atividades da PEPC, MDH e PEPCK (Figura 9 a 12).
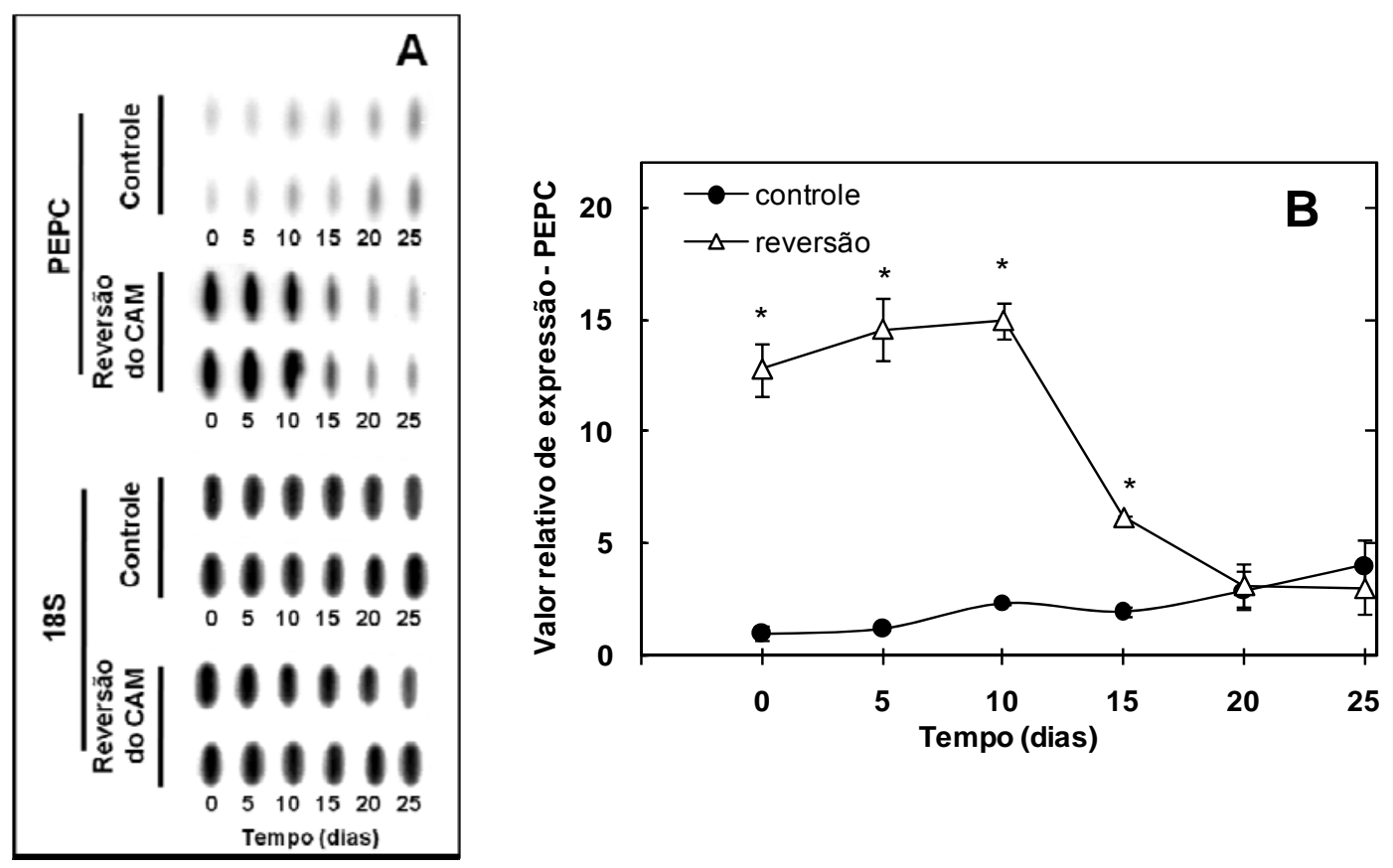

Figura 10. Teores de transcritos da PEPC em folhas de abacaxizeiro durante a reversão da fotossíntese CAM para $\mathrm{C}_{3}$. As condições dos tratamentos foram iguais as da Figura 9. A) Membranas de slot blot hibridadas com sonda para a PEPC ou para o ribossomo 18S (Rib18S) de abacaxizeiro. B) Gráfico mostrando o valor relativo da expressão da PEPC. Os teores de transcritos presentes no tempo 0 foram determinados como 1. Os valores são a média \pm DP de experimentos realizados em duplicata. *, $P<0,05$, Teste $t$, representando diferença significativa entre a condição controle e o tratamento de reversão do CAM. 

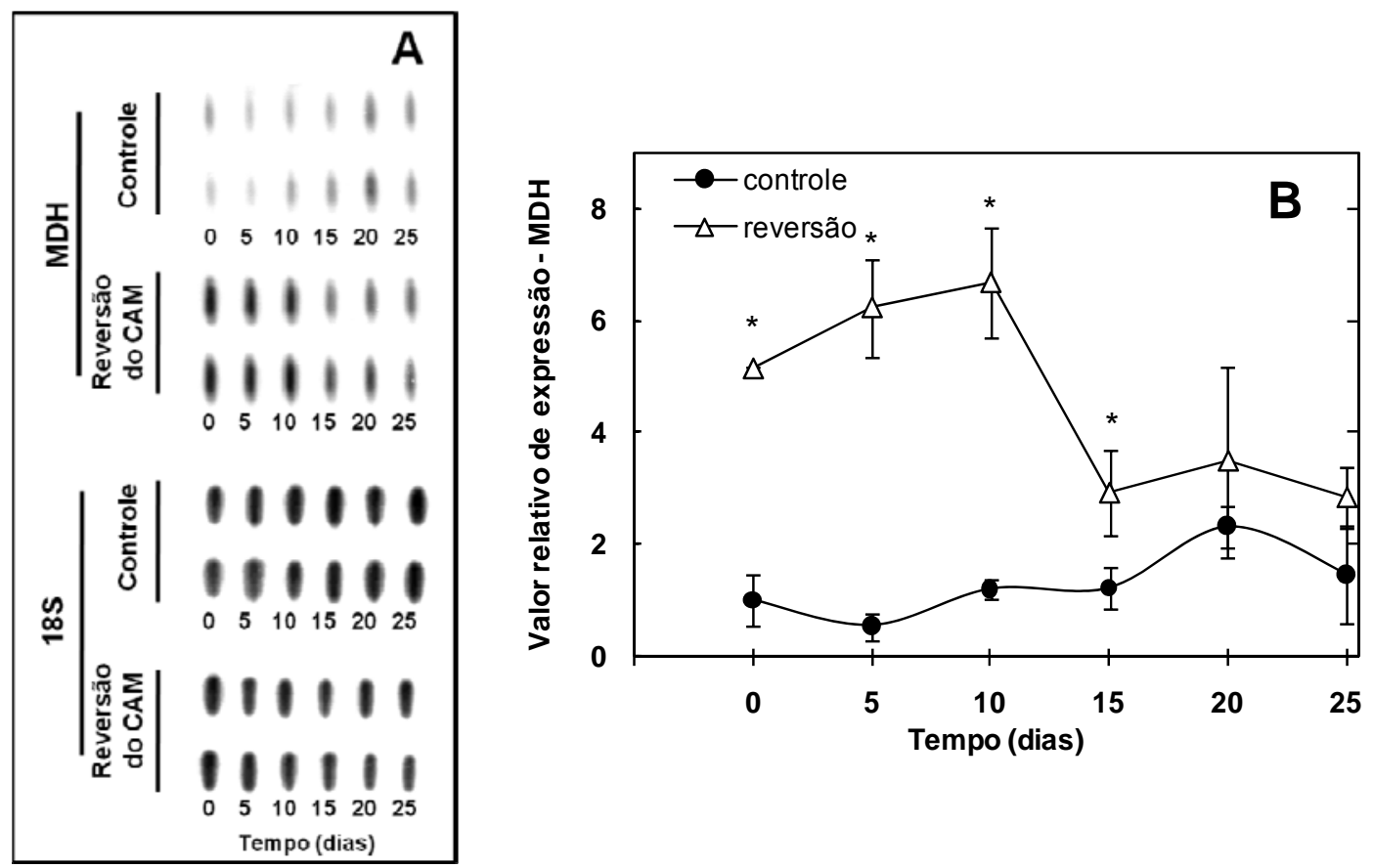

Figura 11. Teores de transcritos da MDH em folhas de abacaxizeiro durante a reversão da fotossíntese CAM para $\mathrm{C}_{3}$. As condições dos tratamentos foram iguais as da Figura 9. A) Membranas de slot blot hibridadas com sonda para a MDH ou para o ribossomo 18S (Rib18S) de abacaxizeiro. B) Gráfico mostrando 0 valor relativo da expressão da $\mathrm{MDH}$. Os teores de transcritos presentes no tempo 0 foram determinados como 1 . Os valores são a média \pm DP de experimentos realizados em duplicata. ${ }^{*}, \mathrm{P}<0,05$, Teste t, representando diferença significativa entre a condição controle e o tratamento de reversão do CAM.
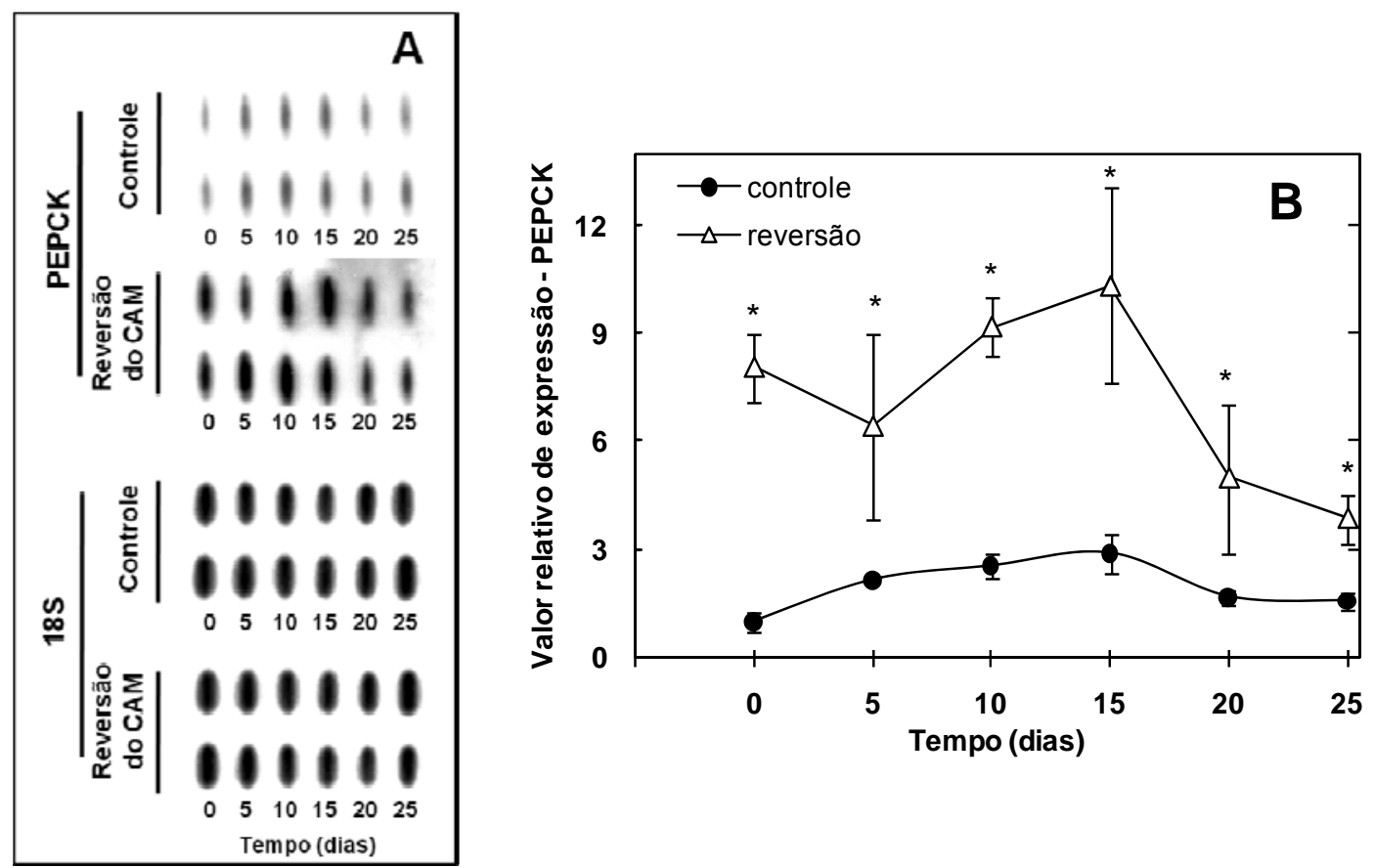

Figura 12. Teores de transcritos da PEPCK em folhas de abacaxizeiro durante a reversão da fotossíntese CAM para $C_{3}$. As condições dos tratamentos foram iguais as da Figura 9. A) Membranas de slot blot hibridadas com sonda para a PEPCK ou para o ribossomo 18S (Rib18S) de abacaxizeiro. B) Gráfico mostrando o valor relativo da expressão da PEPCK. Os teores de transcritos presentes no tempo 0 foram determinados como 1. Os valores são a média \pm DP de experimentos realizados em duplicata. *, $P<0,05$, Teste $t$, representando diferença significativa entre a condição controle e o tratamento de reversão do CAM. 
Dessa forma, os valores de acúmulo noturno de malato e os teores de transcritos e atividade das enzimas analisadas indicaram que a reversão completa do CAM parece ter ocorrido a partir do $20^{\circ}$ dia após o retorno das plantas para a condição controle (Figuras 9 a 12).

O teor relativo de água nas folhas de abacaxizeiro também foi acompanhado durante o período que abrange a reversão do CAM nessa bromélia. Como mostra a Figura 13, houve um aumento progressivo nos teores relativos de água nos tecidos foliares das plantas submetidas ao tratamento de reversão do CAM. Como conseqüência, verificou-se que a partir do $15^{\circ}$ dia de tratamento os valores de conteúdo hídrico foliar foram semelhantes entre as plantas submetidas à reversão do CAM e aquelas mantidas continuamente na condição controle (Figura 13).

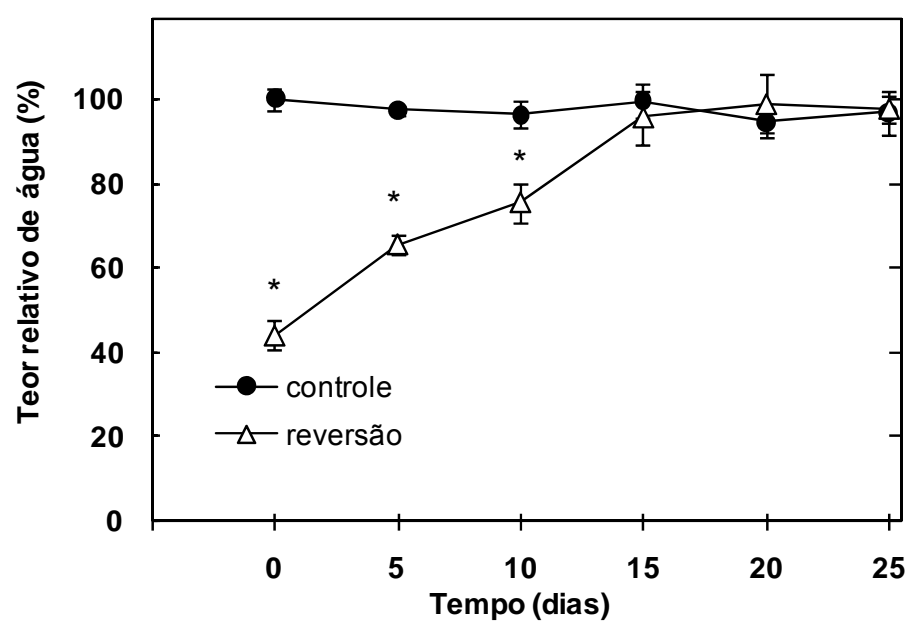

Figura 13. Teor relativo de água em folhas de abacaxizeiro durante a reversão da fotossíntese CAM para $\mathrm{C}_{3}$. As condições dos tratamentos foram iguais as da Figura 9. Os valores mostrados representam a média \pm DP de 15 medições. ${ }^{*}, P<0,05$, Teste $t$, representando diferença significativa entre plantas na condição controle e aquelas submetidas ao tratamento de reversão do CAM.

\section{IV.3. Influência do ácido abscísico sobre a expressão do CAM em abacaxizeiro}

\section{Tratamentos de suplementação ou de inibição da síntese de ABA}

A primeira abordagem utilizada para verificar a influência do ABA sobre a expressão do CAM em abacaxizeiro consistiu na adição desse regulador de crescimento 
à plantas mantidas na condição controle (sem PEG) ou expostas ao estresse hídrico (30\% PEG). Como mostra a Figura 14A, o tratamento das plantas com 10 ou $100 \mu \mathrm{M}$ de ABA na ausência de estresse hídrico promoveu um aumento substancial nos teores de $\Delta$ malato e nas atividades da PEPC, MDH e PEPCK. Esse efeito promotor do ABA sobre a indução do CAM não foi dependente de reduções no conteúdo hídrico relativo das folhas de abacaxizeiro (Tabela 3). Na realidade, os teores relativos de água observados nos tecidos foliares das plantas mantidas na ausência de estresse hídrico e tratadas com 10 ou $100 \mu \mathrm{M}$ de ABA foram, respectivamente, 3.6 e 4.3\% superiores aos constatados nas plantas controle (Tabela 3).

As plantas de abacaxizeiro mantidas na presença de estresse hídrico e tratadas com ABA não apresentaram alterações significativas no acúmulo noturno de malato, nas atividades enzimáticas (Figura 14B) ou, ainda, no conteúdo hídrico foliar (Tabela 3).

Para avaliar se a indução do CAM em abacaxizeiro requer o acúmulo de ABA, foram realizados experimentos de inibição da síntese desse hormônio durante o período que compreende essa mudança de comportamento fotossintético. Para tanto, as plantas de abacaxizeiro foram submetidas a tratamentos com fluridona, um inibidor da síntese de ABA e carotenóides (GAMBLE \& MULLET, 1986), tanto na presença quanto na ausência de estresse hídrico. Verificou-se que a aplicação de 10 ou $100 \mu \mathrm{M}$ desse inibidor desencadeou uma redução de, respectivamente, 52.7 e 99.5\% nos teores endógenos de ABA das plantas expostas ao estresse hídrico (Tabela 4).

A despeito dessa diminuição nos teores de ABA, os tratamentos com fluridona não afetaram o papel estimulatório do estresse hídrico sobre o $\Delta$ malato e as atividades da PEPC, MDH e PEPCK (Figura 14B). De modo geral, as plantas tratadas com fluridona na ausência de estresse hídrico também não apresentaram alterações significativas no acúmulo noturno de malato ou nas atividades enzimáticas, exceto por uma redução de $61 \%$ nos teores de $\Delta$ malato das plantas tratadas com $100 \mu \mathrm{M}$ desse inibidor da síntese de ABA (Figura 14A). A aplicação de fluridona também não afetou o conteúdo relativo de água das folhas de abacaxizeiro (Tabela 3). 


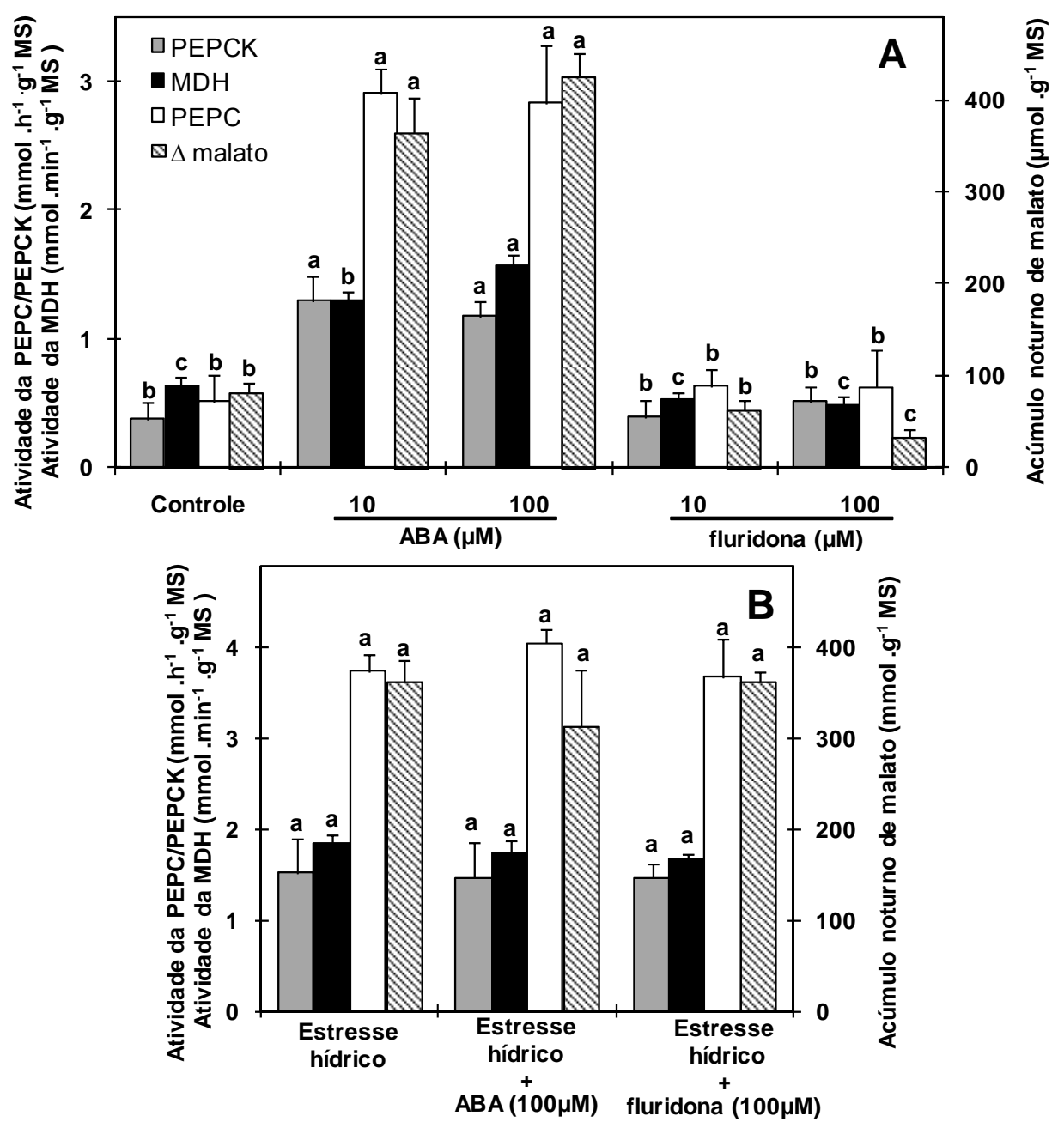

Figura 14. Influência do ácido abscísico sobre a indução do CAM em abacaxizeiro. As plantas foram tratadas com $A B A$ ou fluridona (inibidor da síntese de $A B A$ ) durante 15 dias na ausência de estresse hídrico (A) ou na presença de estresse hídrico (B). Os valores mostrados representam a média \pm DP de dois experimentos realizados em triplicata. Barras com a mesma letra não diferem significativamente pelo teste de Tukey $(P<0,05)$.

Tabela 3: Teor relativo de água nas folhas de abacaxizeiro após 15 dias de tratamento com ABA ou fluridona na presença ou ausência de estresse hídrico. Valores médios ( \pm DP), $n=15$.

\begin{tabular}{lc}
\hline Tratamento & Teor relativo de água (\%) \\
\hline Controle & $96.2( \pm 2.4) \mathrm{b}$ \\
$\mathrm{ABA}(10 \mu \mathrm{M})$ & $99.7( \pm 0.5) \mathrm{a}$ \\
$\mathrm{ABA}(100 \mu \mathrm{M})$ & $100.3( \pm 1.2) \mathrm{a}$ \\
\hline Fluridona $(10 \mu \mathrm{M})$ & $97.5( \pm 1.3) \mathrm{b}$ \\
\hline Fluridona $(100 \mu \mathrm{M})$ & $95.3( \pm 1.2) \mathrm{b}$ \\
\hline Estresse hídrico & $55.8( \pm 2.1) \mathrm{C}$ \\
\hline Estresse hídrico + ABA $(100 \mu \mathrm{M})$ & $52.3( \pm 2.5) \mathrm{C}$ \\
\hline Estresse hídrico + fluridona $(100 \mu \mathrm{M})$ & $56.2( \pm 3.6) \mathrm{c}$ \\
\hline
\end{tabular}

Médias seguidas da mesma letra não diferem significativamente pelo teste de Tukey $(P<0,05)$. 
Tabela 4: Conteúdo foliar de ABA em plantas de abacaxizeiro tratadas com 0, 10 ou $100 \mu \mathrm{M}$ de fluridona por 15 dias na presença de estresse hídrico. Valores médios (ะ DP). Análises realizadas em triplicata.

\begin{tabular}{lc}
\hline Tratamento & Teores de ABA (pmol. $\left.\mathbf{g}^{-1} \mathrm{MS}\right)$ \\
\hline Estresse hídrico & $2014.3( \pm 142.5) \mathrm{a}$ \\
Estresse hídrico + fluridona $(10 \mu \mathrm{M})$ & $952.6( \pm 72.5) \mathrm{b}$ \\
Estresse hídrico + fluridona $(100 \mu \mathrm{M})$ & $10.2( \pm 1.5) \mathrm{c}$ \\
\hline Médias seguidas da mesma letra não diferem significativamente pelo teste de Tukey $(\mathrm{P}<0,05)$.
\end{tabular}

\section{Teores endógenos de ABA durante a indução do CAM}

As quantificações dos teores endógenos de ABA durante o período que abrange a indução do CAM em abacaxizeiro revelaram um aumento progressivo no conteúdo desse hormônio a partir do $2^{\circ}$ dia de exposição das plantas ao estresse hídrico (Figura 15). Assim sendo, houve uma coincidência temporal entre o início do aumento nos teores ABA (Figura $15,2^{\circ}$ dia) e a redução no conteúdo hídrico foliar (Figura $8,1^{\circ} \mathrm{dia}$ ) nas plantas expostas ao estresse hídrico.

Além disso, foi constatada uma tendência de estabilização dos teores de ABA a partir do $8^{\circ}$ dia de tratamento com estresse hídrico (Figura 15). Dessa forma, o maior acúmulo desse hormônio (Figura 15) foi estabelecido justamente quando os menores valores de conteúdo hídrico foliar foram atingidos nas plantas expostas ao estresse hídrico (Figura 8).

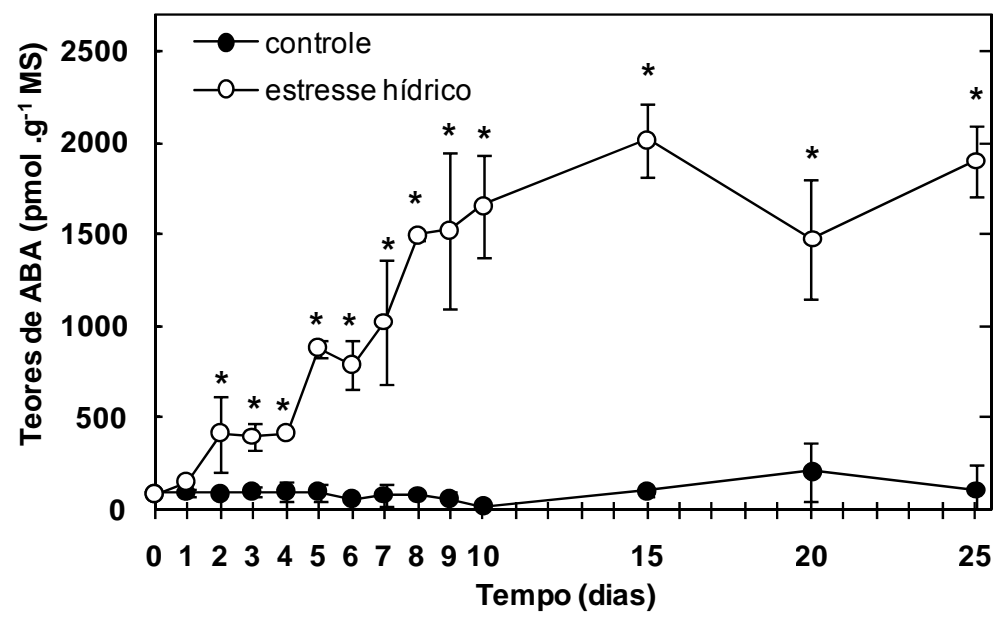

Figura 15. Teores endógenos de ABA em folhas de abacaxizeiro durante a indução do CAM por estresse hídrico. Os valores mostrados representam a média $\pm \mathrm{DP}$ de experimentos realizados em triplicata. ${ }^{*}, \mathrm{P}<$ 0,05 , Teste t, representando diferença significativa entre plantas na condição controle e aquelas submetidas ao estresse hídrico. 


\section{Teores endógenos de ABA durante a reversão do CAM}

As plantas do tratamento de reversão do CAM apresentaram uma redução consideravelmente rápida no conteúdo endógeno de ABA. Como mostra a Figura 16, no $5^{\circ}$ dia após a retorno das plantas para a condição de ausência de estresse hídrico houve uma diminuição de cerca de 55\% nos teores desse hormônio. Verificou-se, ainda, que após $05^{\circ}$ dia de tratamento, os teores de $A B A$ das plantas submetidas à reversão do CAM continuaram a diminuir, atingindo valores similares aos das plantas controle a partir do $20^{\circ}$ dia de experimento (Figura 16).

Por outro lado, as análises revelaram que os teores de ABA das plantas mantidas continuamente na condição controle se mantiveram bastante reduzidos durante todo o período analisado (Figura 16)

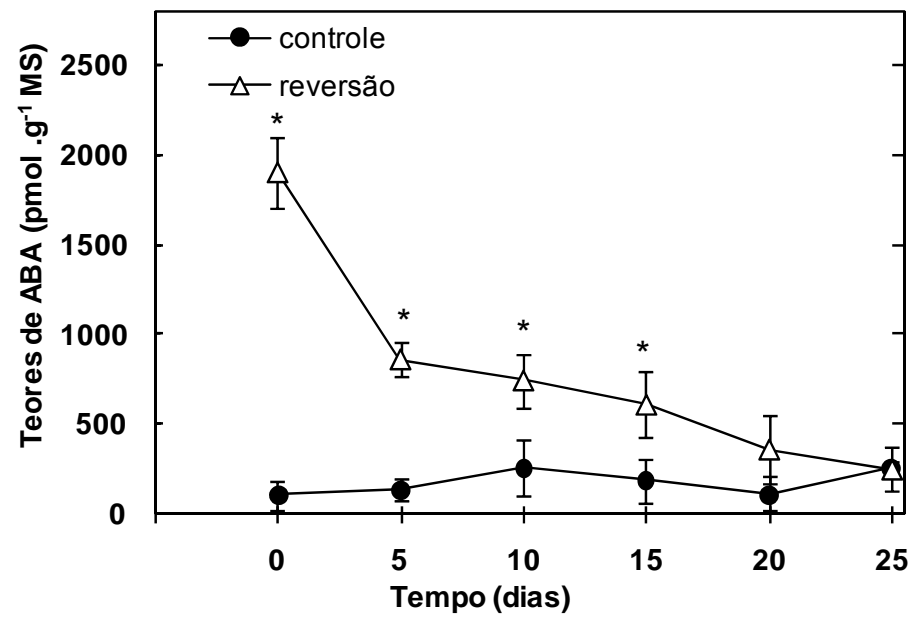

Figura 16. Teores endógenos de ABA em folhas de abacaxizeiro durante a reversão da fotossíntese CAM para $C_{3}$. As condições dos tratamentos foram iguais as da Figura 9. Os valores mostrados representam a média \pm DP de experimentos realizados em triplicata. * $P<0,05$, Teste $t$, representando diferença significativa entre a condição controle e o tratamento de reversão do CAM.

\section{IV.4. Influência das citocininas sobre a expressão do CAM em abacaxizeiro}

\section{$\underline{\text { Tratamentos de suplementação com citocininas }}$}

Primeiramente, foram realizados tratamentos que combinaram a presença ou ausência de estresse hídrico com a adição de $10 \mu \mathrm{M}$ de zeatina $(Z)$, zeatina ribosídica $(\mathrm{ZR})$, isopenteniladenina (iP) ou isopenteniladenina ribosídica (iPR). 
Em geral, observou-se que as plantas mantidas na ausência de estresse hídrico e tratadas com essas citocininas não apresentaram alterações pronunciadas nos teores de $\Delta$ malato e nas atividades enzimáticas (Figura 17A). Por outro lado, as plantas tratadas com $10 \mu \mathrm{M}$ de $\mathrm{Z}, \mathrm{ZR}$, iP ou iPR e mantidas na presença de estresse hídrico apresentaram valores de atividade enzimática e de acúmulo noturno de malato substancialmente inferiores àqueles observados nas plantas expostas apenas ao estresse hídrico (Figura 17B). Comparativamente, Z e ZR foram as citocininas que desencadearam as maiores reduções no $\Delta$ malato e na atividade da PEPC das plantas tratadas com estresse hídrico (Figura 17B).
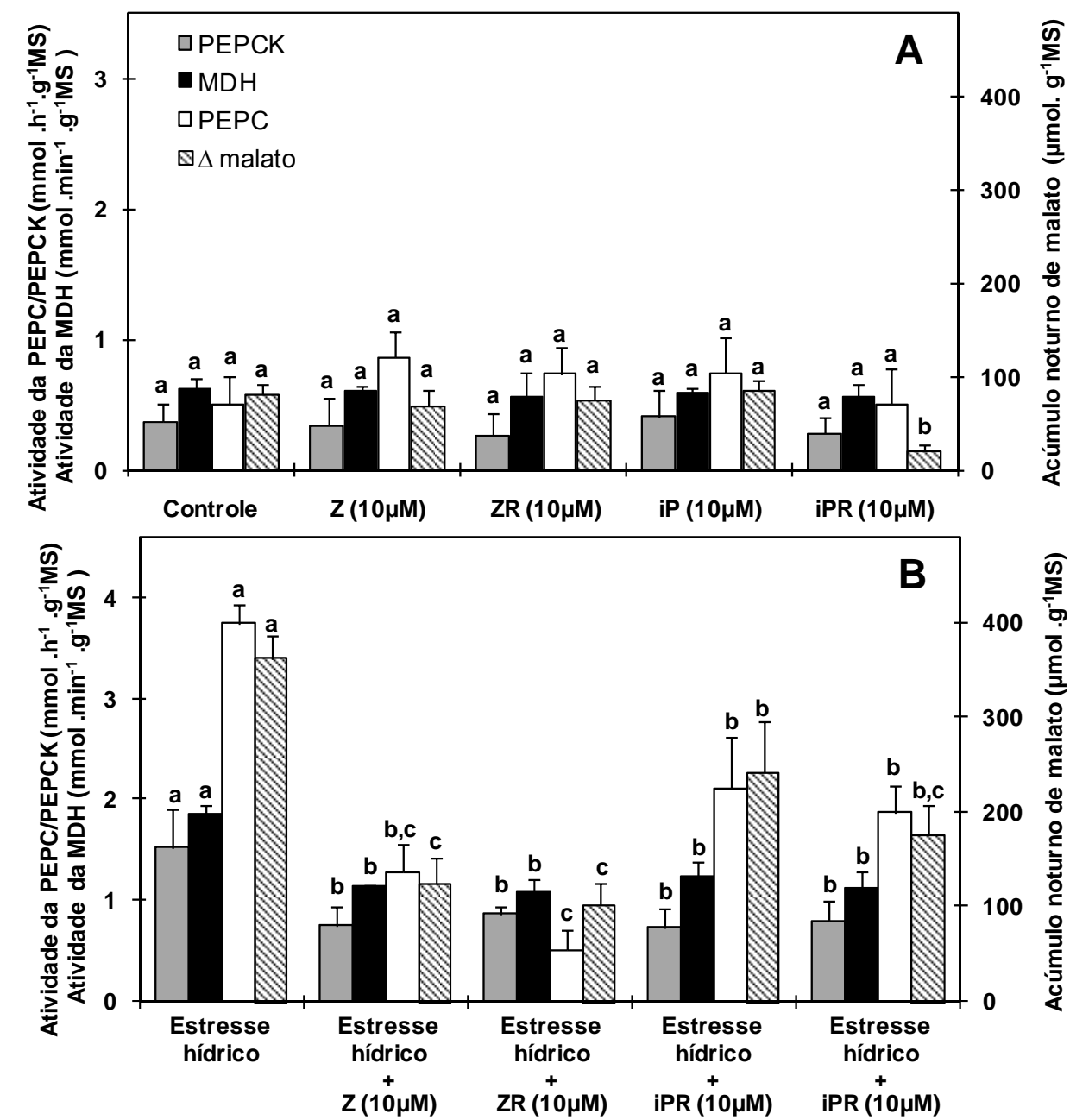

Figura 17. Influência de tratamentos com citocininas sobre a indução do CAM em abacaxizeiro. As plantas foram tratadas por 15 dias com 0 ou $10 \mu \mathrm{M}$ de Z, ZR, iP ou iPR na ausência de estresse hídrico (A) ou na presença de estresse hídrico (B). Média \pm DP de dois experimentos realizados em triplicata. Barras com a mesma letra não diferem significativamente pelo teste de Tukey $(P<0,05)$. 
Os tratamentos com citocininas não provocaram alterações consideráveis no teor relativo de água das folhas de abacaxizeiro, exceto por um ligeiro aumento constatado nas plantas tratadas com Z ou iPR na ausência de estresse hídrico (Tabela 5).

Tabela 5: Teor relativo de água nas folhas de abacaxizeiro após 15 dias de tratamento com citocininas na presença ou ausência de estresse hídrico. Valores médios ( \pm DP), $n=10$.

\begin{tabular}{lc}
\hline Tratamento & Teor relativo de água (\%) \\
\hline Controle & $96.2( \pm 2.4) \mathrm{b}$ \\
\hline $\mathrm{Z}(10 \mu \mathrm{M})$ & $99.8( \pm 1.1) \mathrm{a}$ \\
$\mathrm{ZR}(10 \mu \mathrm{M})$ & $95.4( \pm 2.2) \mathrm{b}$ \\
$\mathrm{iP}(10 \mu \mathrm{M})$ & $96.3( \pm 2.4) \mathrm{b}$ \\
iPR $(10 \mu \mathrm{M})$ & $97.8( \pm 1.6) \mathrm{a}$ \\
\hline Estresse hídrico & $55.8( \pm 2.1) \mathrm{c}$ \\
\hline Estresse hídrico + Z $(10 \mu \mathrm{M})$ & $53.5( \pm 2.7) \mathrm{c}$ \\
\hline Estresse hídrico + ZR $(10 \mu \mathrm{M})$ & $56.9( \pm 3.6) \mathrm{c}$ \\
\hline Estresse hídrico + iP $(10 \mu \mathrm{M})$ & $55.2( \pm 2.6) \mathrm{c}$ \\
Estresse hídrico + iPR $(10 \mu \mathrm{M})$ & $54.7( \pm 3.1) \mathrm{c}$ \\
\hline
\end{tabular}

\section{Teores endógenos de citocininas durante a inducão do CAM}

Também foram realizadas quantificações dos teores de Z, ZR, iP e iPR durante o período que compreende a indução de $A$. comosus ao CAM em resposta ao estresse hídrico. Como mostra a Figura 18, os teores endógenos das quatro citocininas analisadas apresentaram uma redução simultânea entre $06^{\circ}$ e $8^{\circ}$ dia após a transferência das plantas para a condição de estresse hídrico.

As citocininas do tipo zeatina, Z e ZR, tiveram suas concentrações diminuídas em respectivamente 73 e $84 \%$, sendo que essa redução esteve compreendida principalmente entre $5^{\circ}$ e $7^{\circ}$ dia após o início do tratamento de estresse hídrico (Figuras 18A e B). Por outro lado, os teores das citocininas do tipo isopenteniladenina, iP e iPR, sofreram uma redução um pouco menos pronunciada (65 e 53\%, respectivamente) tendo essa ocorrido especialmente entre $06^{\circ}$ e $8^{\circ}$ dia após a transferência das plantas para a condição de estresse hídrico (Figuras 18C e D). 

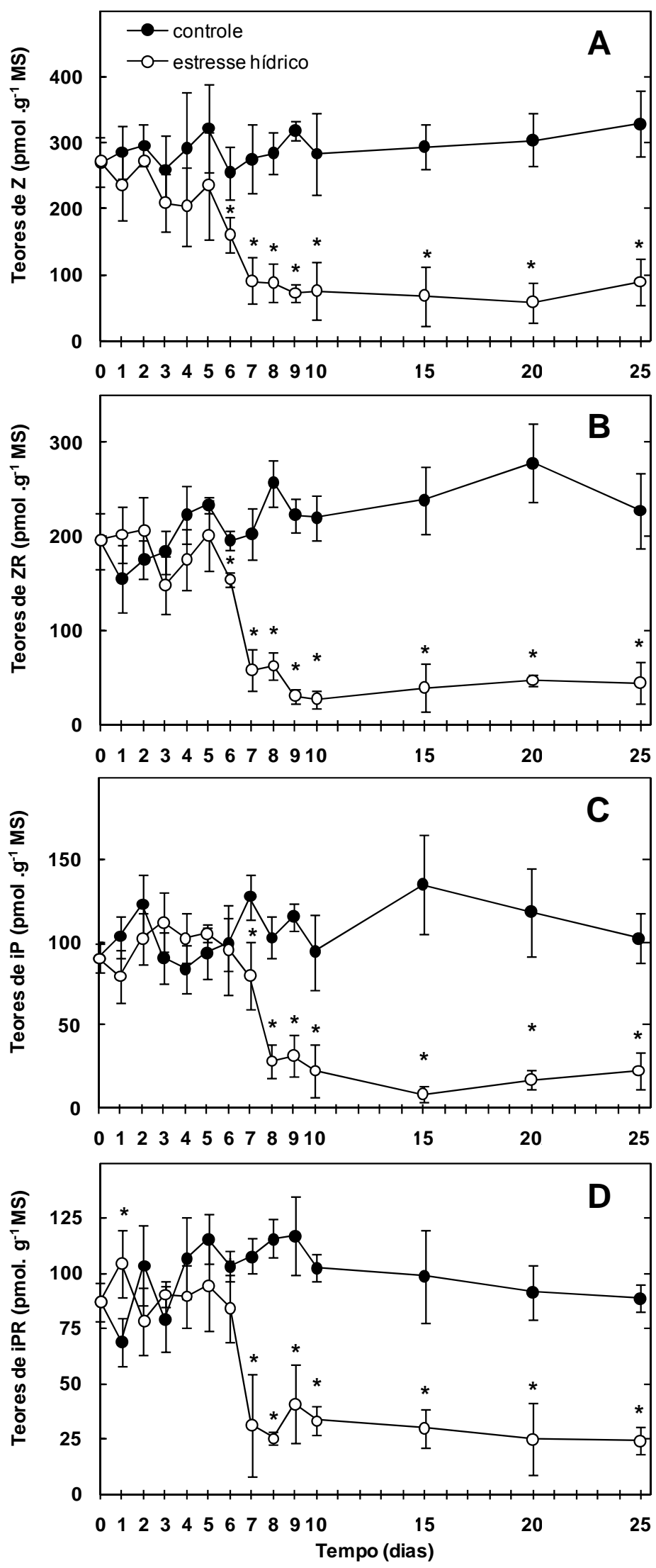

Figura 18. Teores endógenos de Z (A), ZR (B), iP (C) e iPR (D) em folhas de abacaxizeiro durante a indução do CAM por estresse hídrico. Os valores mostrados representam a média \pm DP de experimentos realizados em triplicata. ${ }^{*}, P<0,05$, Teste $t$, representando diferença significativa entre a condição controle e 0 tratamento de estresse hídrico. 
As alterações nos teores de Z, ZR, iP e iPR refletiram numa redução de aproximadamente $60 \%$ no conteúdo geral de citocininas entre o $6^{\circ}$ e $8^{\circ}$ dia de incubação das plantas na presença de estresse hídrico (Figura 19). Após a redução nos teores endógenos de citocininas, esses permaneceram praticamente inalterados durante 0 restante do período de exposição ao estresse hídrico (Figura 18 e 19). Cabe ressaltar que o período de maior diminuição nos teores de citocininas (Figura $19,6^{\circ}-8^{\circ}$ dia) foi precedido pela ocorrência de uma redução pronunciada nos teores de água nas folhas de abacaxizeiro (Figura $8,4^{\circ}-6^{\circ} \mathrm{dia}$ ).

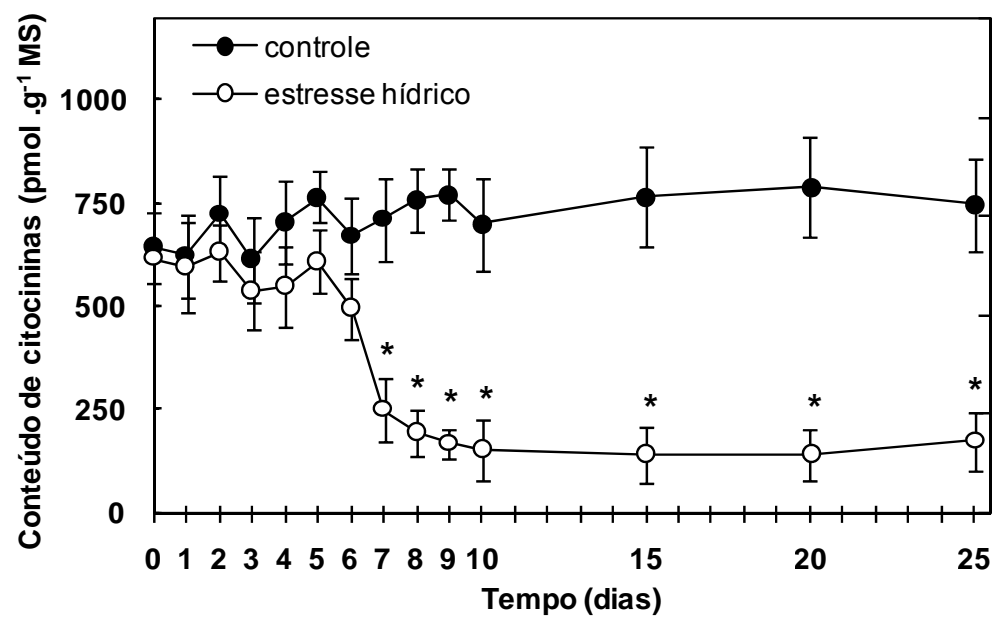

Figura 19. Conteúdo de citocininas ( $Z+Z R+i P+i P R)$ em folhas de abacaxizeiro durante a indução do CAM por estresse hídrico. Os valores mostrados representam a média \pm DP de experimentos realizados em triplicata. *, $P<0,05$, Teste $t$, representando diferença significativa entre a condição controle e 0 tratamento de estresse hídrico.

\section{$\underline{\text { Teores endógenos de citocininas durante a reversão do CAM }}$}

Como mostra a Figura 20 , as plantas submetidas à reversão do CAM apresentaram um aumento gradativo nos teores de Z, ZR, iP e iPR durante o período de análise. Foi constatado que as plantas do tratamento de reversão do CAM apresentaram um incremento de cerca de 3 vezes nos teores endógenos de Z e ZR durante o período de realização dos experimentos, contudo, estes ainda continuaram abaixo dos níveis observados nas plantas controle (Figura 20A e B). Por outro lado, os teores de iP e iPR das plantas submetidas à reversão do CAM alcançaram valores semelhantes aos das plantas controle a partir do $20^{\circ}$ dia de tratamento (Figura $20 \mathrm{C}$ e D). 

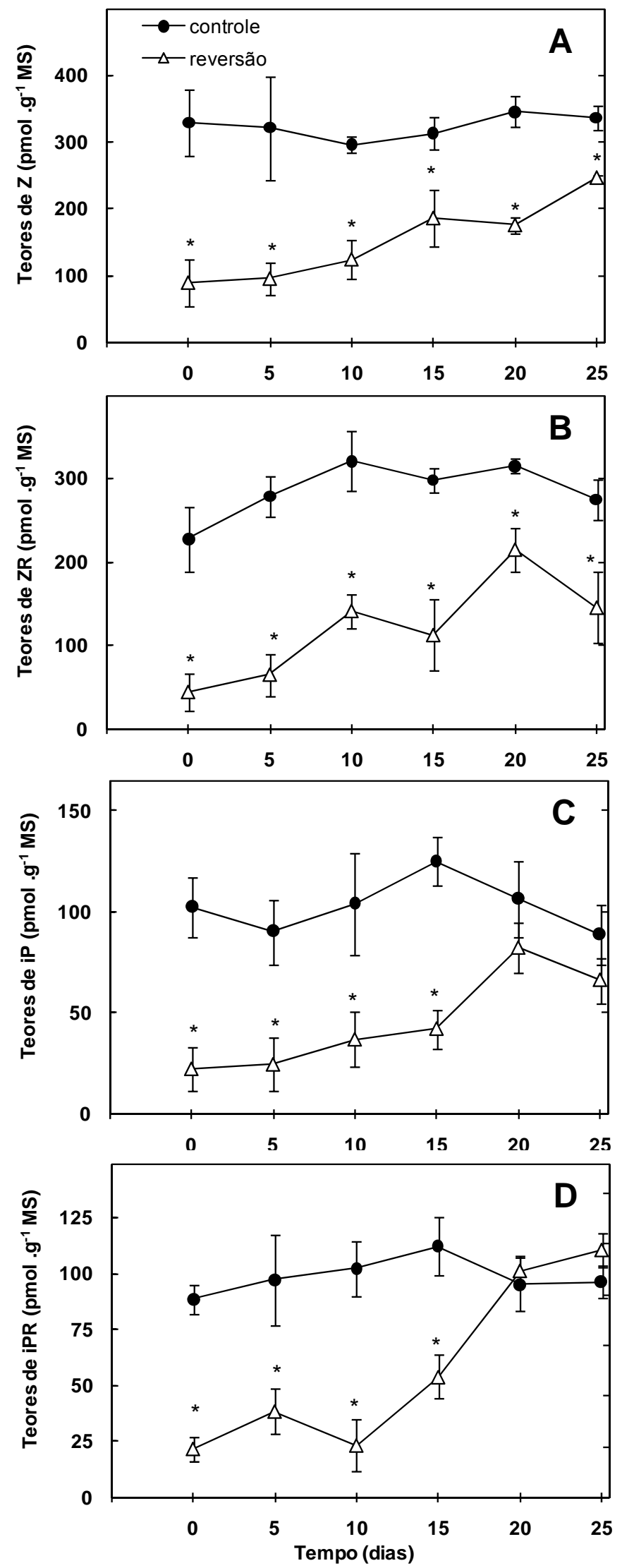

Figura 20. Teores endógenos de Z (A), ZR (B), iP (C) e iPR (D) em folhas de abacaxizeiro durante a reversão da fotossíntese CAM para $C_{3}$. As condições dos tratamentos foram iguais as da Figura 9. Os valores mostrados representam a média $\pm D P$ de experimentos realizados em triplicata. *, $P<0,05$, Teste $t$, representando diferença significativa entre a condição controle e o tratamento de reversão do CAM. 
O conteúdo geral de citocininas $(Z+Z R+i P+i P R)$ também apresentou um aumento progressivo durante o tratamento de reversão do CAM, mas continuou sendo inferior aos teores dessa classe hormonal detectados nas plantas controle (Figura 21).

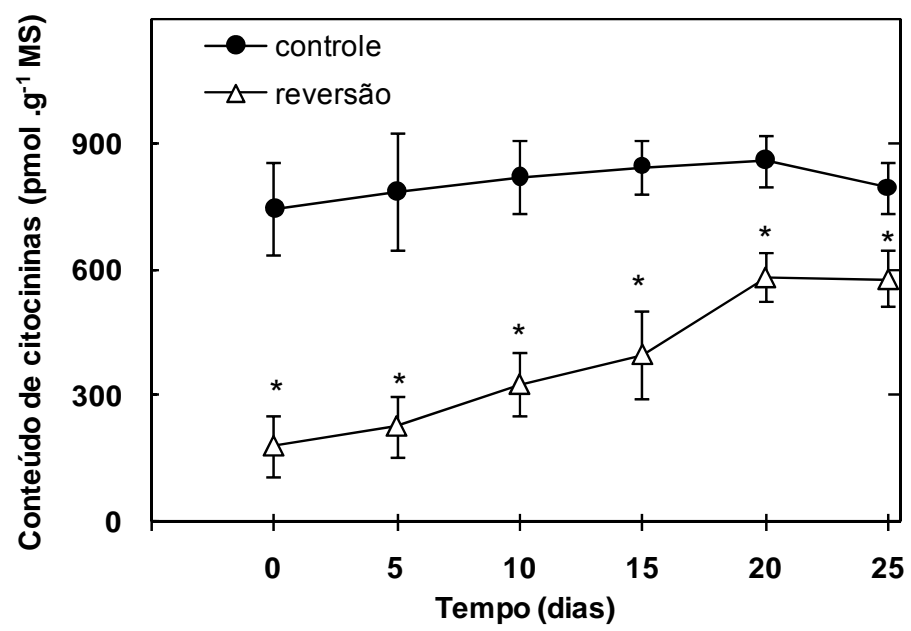

Figura 21. Conteúdo geral de citocininas $(Z+Z R+i P+i P R)$ em folhas de abacaxizeiro durante a reversão da fotossíntese CAM para $C_{3}$. As condições dos tratamentos foram iguais as da Figura 9. Os valores mostrados representam a média \pm DP de experimentos realizados em triplicata. *, $\mathrm{P}<0,05$, Teste $\mathrm{t}$, representando diferença significativa entre a condição controle e o tratamento de reversão do CAM.

\section{IV.5. Influência das auxinas sobre a expressão do CAM em abacaxizeiro}

\section{$\underline{\text { Tratamentos de suplementação ou de inibição do transporte polar de auxinas }}$}

Os teores de $\Delta$ malato e das atividades da PEPC e MDH foram quantificados em plantas de abacaxizeiro submetidas a tratamentos que combinaram a presença ou ausência de estresse hídrico com a aplicação de ácido indolilacético (AIA), uma auxina natural, ou de ácido n-1-naftilftalâmico (NPA), um inibidor do transporte polar de auxinas. Essas análises revelaram que os teores de $\Delta$ malato e de atividade da PEPC e $\mathrm{MDH}$ das plantas submetidas aos tratamentos com AIA ou NPA não diferiram estatisticamente daqueles observados nas plantas não tratadas com esses compostos, seja na presença ou na ausência de estresse hídrico (Figura 22). A única diferença estatística constatada nesses experimentos foi uma redução de aproximadamente $75 \%$ na atividade da MDH das plantas tratadas com $100 \mu \mathrm{M}$ de AIA na ausência de estresse hídrico (Figura 22A). 


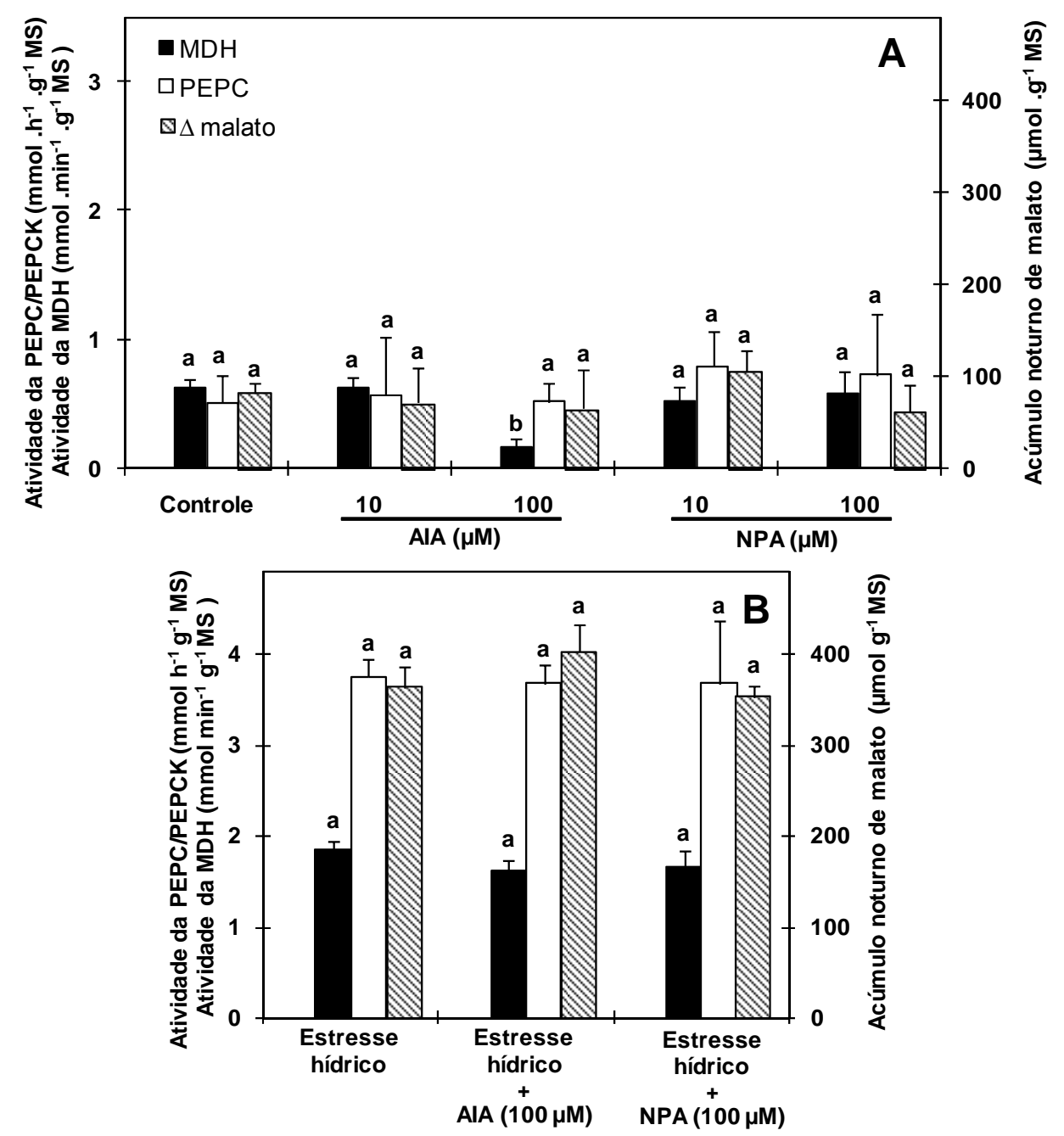

Figura 22. Influência das auxinas sobre a indução do CAM em abacaxizeiro. As plantas foram tratadas com AIA ou NPA (inibidor do transporte polar de auxinas) durante 15 dias na ausência de estresse hídrico (A) ou na presença de estresse hídrico (B). A atividade da PEPCK não foi quantificada nesses experimentos. Os valores mostrados representam a média \pm DP de dois experimentos realizados em triplicata. Barras com a mesma letra não diferem significativamente pelo teste de Tukey $(P<0,05)$.

Tabela 6: Teor relativo de água nas folhas de abacaxizeiro após 15 dias de tratamento com AIA ou NPA na presença ou ausência de estresse hídrico. Valores médios ( \pm DP), $n=15$.

\begin{tabular}{lc}
\hline Tratamento & Teor relativo de água (\%) \\
\hline Controle & $96.2( \pm 2.4) \mathrm{a}$ \\
AIA $(10 \mu \mathrm{M})$ & $96.7( \pm 1.4) \mathrm{a}$ \\
AIA $(100 \mu \mathrm{M})$ & $95.5( \pm 2.5) \mathrm{a}$ \\
$\mathrm{NPA}(10 \mu \mathrm{M})$ & $97.6( \pm 3.3) \mathrm{a}$ \\
$\mathrm{NPA}(100 \mu \mathrm{M})$ & $91.1( \pm 1.1) \mathrm{b}$ \\
Estresse hídrico & $55.8( \pm 2.1) \mathrm{C}$ \\
Estresse hídrico $+\mathrm{AIA}(100 \mu \mathrm{M})$ & $51.8( \pm 3.6) \mathrm{C}$ \\
Estresse hídrico + NPA $(100 \mu \mathrm{M})$ & $54.4( \pm 1.7) \mathrm{c}$ \\
\hline
\end{tabular}

Médias seguidas da mesma letra não diferem significativamente pelo teste de Tukey $(P<0,05)$. 
Os tratamentos com AIA ou NPA também não resultaram em alterações significativas no teor relativo de água das folhas de abacaxizeiro, exceto por uma diminuição de $5.3 \%$ no conteúdo hídrico foliar das plantas tratadas com $100 \mu \mathrm{M}$ de NPA na ausência de estresse hídrico (Tabela 6).

\section{$\underline{\text { Teores endógenos de auxina durante a indução do CAM }}$}

As análises dos teores endógenos de AIA em abacaxizeiro evidenciaram poucas variações no conteúdo desse hormônio tanto nas plantas mantidas na condição controle quanto naquelas submetidas ao tratamento de estresse hídrico (Figura 23). Os teores de AIA detectados nas plantas controle não diferiram significativamente daqueles observados nas plantas tratadas com estresse hídrico durante os primeiros 6 dias de experimento. Contudo, a partir do $7^{\circ}$ dia de tratamento, as plantas expostas ao estresse hídrico passaram a apresentar teores de AIA superiores aos observados nas plantas controle (Figura 23).

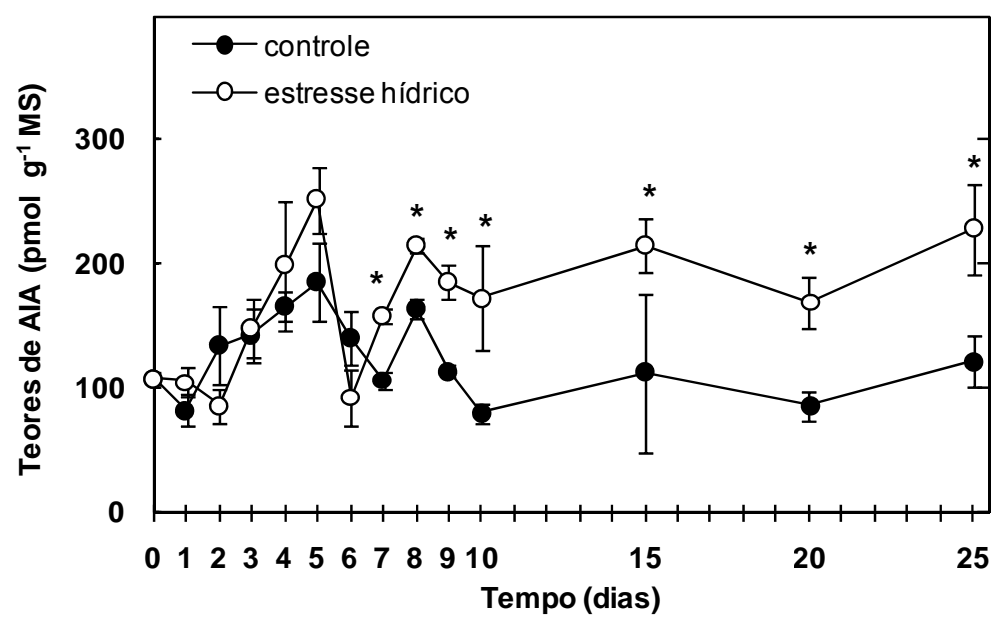

Figura 23. Teores endógenos de AIA em folhas de abacaxizeiro durante a indução do CAM por estresse hídrico. Os valores mostrados representam a média \pm DP de experimentos realizados em duplicata. ${ }^{*}, \mathrm{P}<$ 0,05 , Teste $t$, representando diferença significativa entre a condição controle e 0 tratamento de estresse hídrico.

\section{Teores endógenos de auxina durante a reversão do CAM}

Como mostra a Figura 24, os teores de AlA observados nas plantas submetidas à reversão do CAM foram bastante similares aos das plantas controle durante quase todo 
o período analisado. A única diferença estatística observada foi a detecção de teores de AIA um pouco mais elevados nas plantas submetidas à reversão do CAM no tempo 0 e após 20 dias de tratamento.

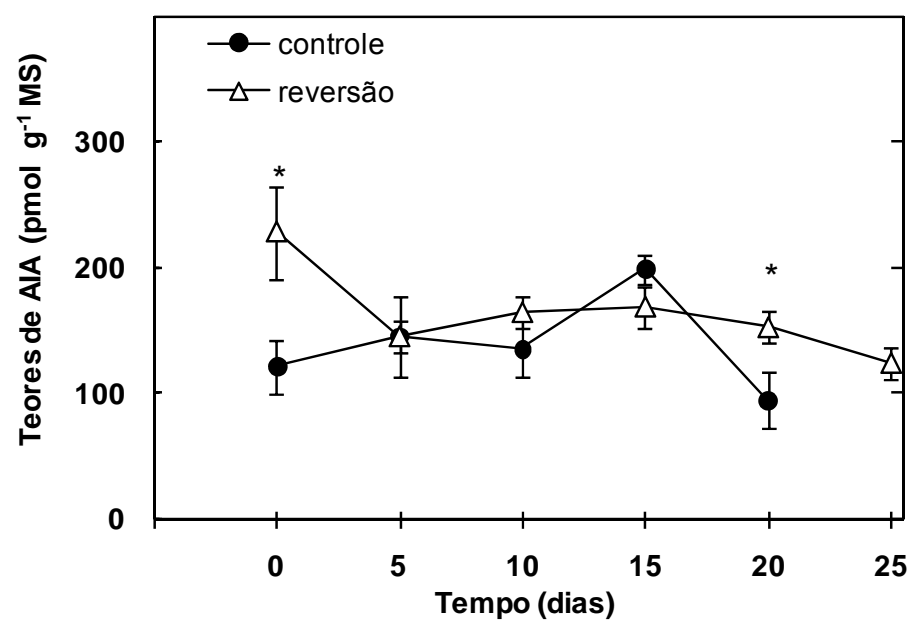

Figura 24. Teores endógenos de AIA em folhas de abacaxizeiro durante a reversão da fotossíntese CAM para $C_{3}$. As condições dos tratamentos foram iguais as da Figura 9. A amostra referente ao $25^{\circ}$ dia de controle não foi quantificada. Os valores mostrados representam a média \pm DP de experimentos realizados em duplicata. *, $\mathrm{P}<0,05$, Teste $\mathrm{t}$, representando diferença significativa entre a condição controle e 0 tratamento de reversão do CAM.

\section{IV.6. Influência do etileno sobre a expressão do CAM em abacaxizeiro}

\section{$\underline{\text { Tratamentos de suplementação com etileno ou de inibição de sua percepção }}$}

Os níveis de expressão do CAM também foram caracterizados em plantas de abacaxizeiro mantidas na presença ou ausência de estresse hídrico e tratadas com etileno ou com um inibidor irreversível dos receptores para esse hormônio, o 1metilciclopropeno (1-MCP).

Os resultados obtidos revelaram que os tratamentos de suplementação com etileno (50 ou $500 \mu \mathrm{M})$ não afetaram o tipo de comportamento fotossintético apresentado por $A$. comosus (Figura 25). Observou-se que, de modo geral, os teores de $\triangle$ malato e de atividade da PEPC, MDH e PEPCK das plantas tratadas com esse regulador de crescimento foram similares aos detectados nas plantas controle, tanto na presença quanto na ausência de estresse hídrico (Figura 25). A única diferença 
significativa constatada ao longo desses tratamentos restringiu-se a uma redução de aproximadamente $80 \%$ no teor de atividade da PEPCK das plantas tratadas com 500 $\mu \mathrm{M}$ de etileno na ausência de estresse hídrico (Figura 25A).

De modo similar ao observado nos experimentos com etileno, os tratamentos com 1-MCP também não desencadearam alterações consideráveis nas atividades enzimáticas ou no acúmulo noturno de ácidos orgânicos em $A$. comosus, exceto por uma redução de 31.4 e $43.9 \%$ nas atividades da MDH e da PEPCK detectada nas plantas tratadas com $100 \mu \mathrm{M}$ desse composto na presença de estresse hídrico (Figura 25B).

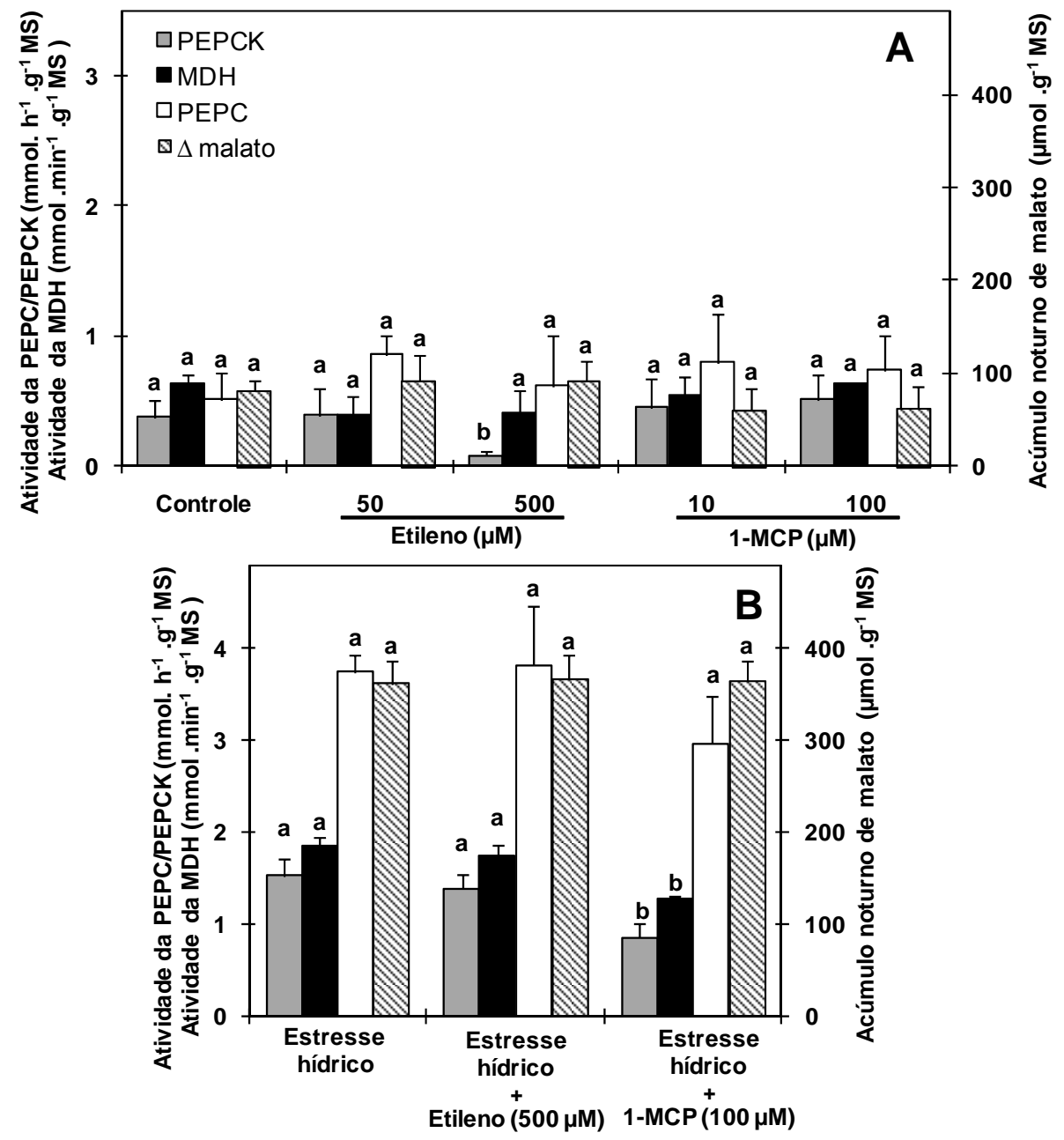

Figura 25. Influência do etileno sobre a indução do CAM em abacaxizeiro. As plantas foram tratadas com etileno ou 1-MCP (inibidor dos receptores de etileno) durante 15 dias na ausência de estresse hídrico (A) ou na presença de estresse hídrico (B). As aplicações de etileno ou 1-MCP foram realizadas semanalmente. Os valores mostrados representam a média \pm DP de experimentos realizados em triplicata. Barras com a mesma letra não diferem significativamente pelo teste de Tukey $(P<0,05)$. 
Tabela 7: Teor relativo de água nas folhas de abacaxizeiro após 15 dias de tratamento com etileno ou 1MCP na presença ou ausência de estresse hídrico. Valores médios ( \pm DP), $n=10$.

\begin{tabular}{lc}
\hline Tratamento & Teor relativo de água (\%) \\
\hline Controle & $96.2( \pm 2.4) \mathrm{a}$ \\
\hline Etileno $(50 \mu \mathrm{M})$ & $94.9( \pm 3.7) \mathrm{a}$ \\
Etileno $(500 \mu \mathrm{M})$ & $97.4( \pm 2.7) \mathrm{a}$ \\
1-MCP $(10 \mu \mathrm{M})$ & $95.2( \pm 4.8) \mathrm{a}$ \\
1-MCP $(100 \mu \mathrm{M})$ & $93.7( \pm 3.4) \mathrm{a}$ \\
Estresse hídrico & $55.8( \pm 2.1) \mathrm{b}$ \\
Estresse hídrico + etileno $(500 \mu \mathrm{M})$ & $57.8( \pm 85.2) \mathrm{b}$ \\
Estresse hídrico + 1-MCP $(100 \mu \mathrm{M})$ & $57.4( \pm 57.8) \mathrm{b}$ \\
\hline Médias seguidas da mesma letra não diferem significativamente pelo teste de Tukey $(\mathrm{P}<0,05)$.
\end{tabular}

Além de não ter influenciado o tipo de comportamento fotossintético, os tratamentos com etileno ou 1-MCP também não promoveram alterações consideráveis no teor relativo de água das folhas de abacaxizeiro (Tabela 7).

\section{$\underline{\text { Teores de emissão de etileno durante a indução do CAM }}$}

Os teores de emissão de etileno foram bastante semelhantes entre as plantas submetidas à indução do CAM por estresse hídrico e aquelas mantidas na condição controle (Figura 26). Constatou-se apenas que os teores de emissão de etileno observados no $6^{\circ}, 7^{\circ}$ e $15^{\circ}$ dia de exposição das plantas ao estresse hídrico foram ligeiramente superiores aos detectados nas plantas mantidas na condição controle (Figura 26). 


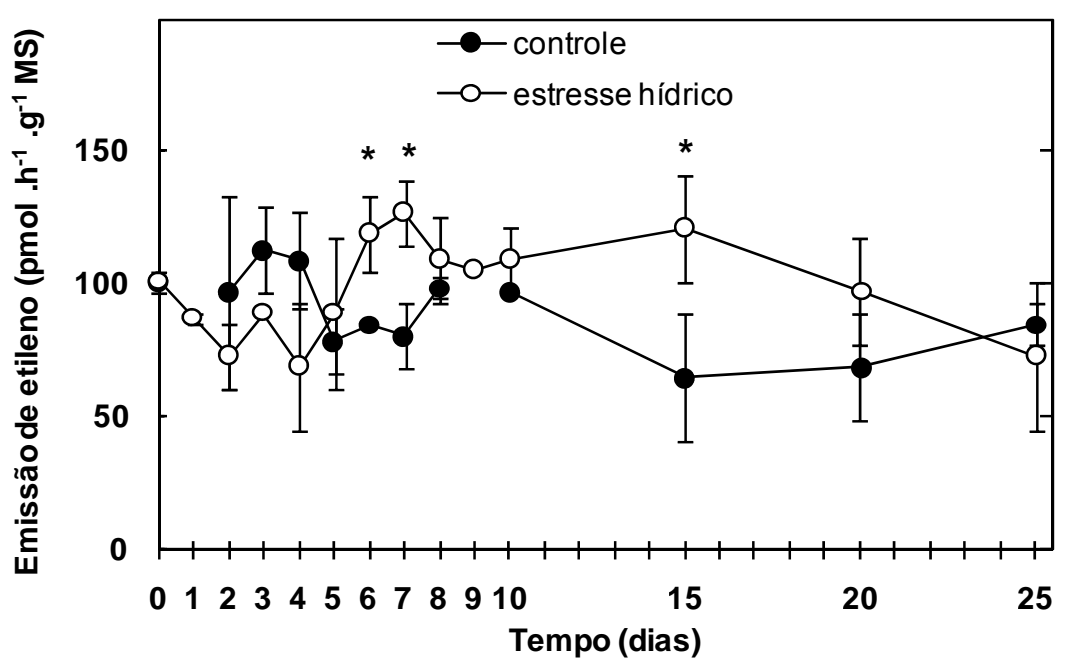

Figura 26. Teores de emissão de etileno por plantas de abacaxizeiro durante a indução do CAM por estresse hídrico. Os valores mostrados representam a média \pm DP de experimentos realizados em duplicata. As amostras referentes ao $1^{\circ}$ e $9^{\circ}$ dias de controle não foram quantificadas *, $P<0,05$, Teste $t$, representando diferença significativa entre a condição controle e o tratamento de estresse hídrico.

\section{Teores de emissão de etileno durante a reversão do CAM}

Com mostra a Figura 27, entre $\circ 5^{\circ}$ e $20^{\circ}$ dia de tratamento, as plantas de abacaxizeiro submetidas à reversão do CAM apresentam teores de emissão de etileno um pouco superiores àqueles quantificados nas plantas mantidas na condição controle. Nos demais pontos analisados, os teores de emissão de etileno pelas plantas do tratamento de reversão do CAM foram similares aos detectados nas plantas controle. (Figura 27).

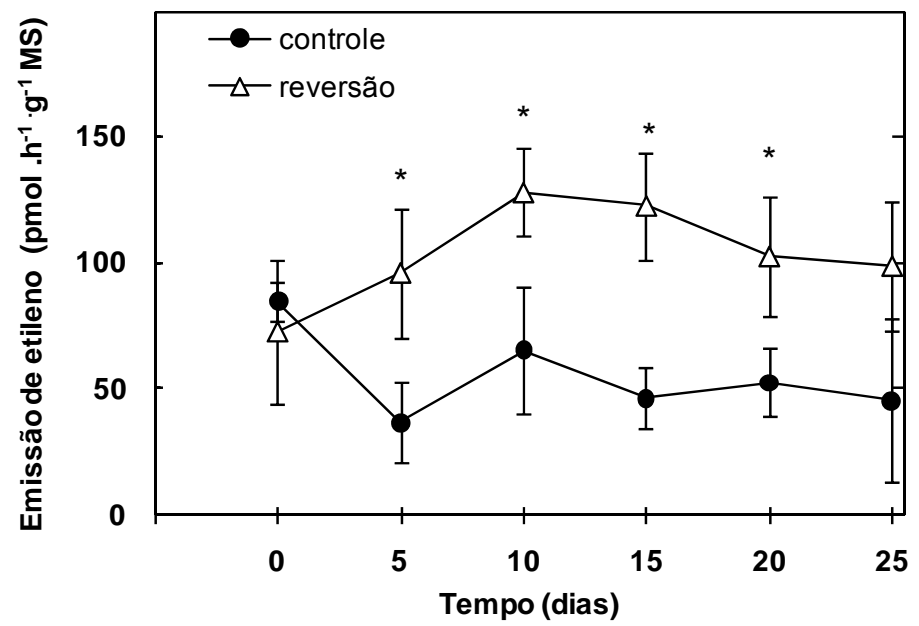

Figura 27. Teores de emissão de etileno em plantas abacaxizeiro durante a reversão da fotossíntese CAM para $C_{3}$. As condições dos tratamentos foram iguais as da Figura 9. Os valores mostrados representam a média \pm DP de experimentos realizados em triplicata. *, $\mathrm{P}<0,05$, Teste $\mathrm{t}$, representando diferença significativa entre a condição controle e o tratamento de reversão do CAM. 


\section{IV.7. Influência do cálcio citossólico na expressão do CAM em abacaxizeiro}

\section{Tratamentos com ionóforo de $\mathrm{Ca}^{2+}$ ou quelante de $\mathrm{Ca}^{2+}$ extracelular}

Como mostra a Figura 28A, a aplicação de ionomicina, um ionóforo específico para o $\mathrm{Ca}^{2+}$, apresentou um papel estimulatório sobre a expressão do CAM em plantas de abacaxizeiro. Observou-se que as plantas tratadas com $10 \mu \mathrm{M}$ de ionomicina na ausência de estresse hídrico apresentaram valores de $\Delta$ malato e de atividade enzimática entre 1.6 e 4.2 vezes maiores que aqueles observados nas plantas não tratadas com esse ionóforo (Figura 28A). Por outro lado, o tratamento das plantas com 1 $\mu \mathrm{M}$ de ionomicina, também na ausência de estresse hídrico, resultou em aumento significativo apenas nos teores de acúmulo noturno de malato e atividade da PEPC, não afetando as atividades da MDH e PEPCK (Figura 28A). Verificou-se, ainda, que os tratamentos com 1 ou $10 \mu \mathrm{M}$ de ionomicina não alteraram significativamente o teor relativo de água das folhas de abacaxizeiro (Tabela 8).

Também foi investigado se $\mathrm{o}$ influxo de $\mathrm{Ca}^{2+}$ do meio extracelular estaria envolvido na sinalização do CAM em abacaxizeiro, utilizando-se, para tanto, tratamentos com o ácido etilenoglicol-bis(-aminoetileter)-tetracético (EGTA), um quelante de $\mathrm{Ca}^{2+}$ extracelular. Como mostra a Figura 28B, a aplicação de EGTA mostrou-se inibitória à indução de $A$. comosus ao CAM em resposta ao estresse hídrico, sendo que, a intensidade desse efeito foi proporcional à concentração utilizada do quelante.

As plantas tratadas com $1 \mathrm{mM}$ de EGTA na presença de estresse hídrico apresentaram valores de atividade enzimática e de $\Delta$ malato entre 24 e $45 \%$ inferiores aos detectados nas plantas não tratadas com esse quelante (Figura 28B). Já nas plantas tratadas com 10 mM de EGTA observou-se uma inibição ainda mais intensa do efeito do estresse hídrico sobre a indução do CAM, uma vez que os teores de $\Delta$ malato e as atividades enzimáticas detectadas nessas plantas foram entre 62 e $76 \%$ inferiores àqueles observados nas plantas expostas ao estresse hídrico na ausência de EGTA (Figura 28B) 

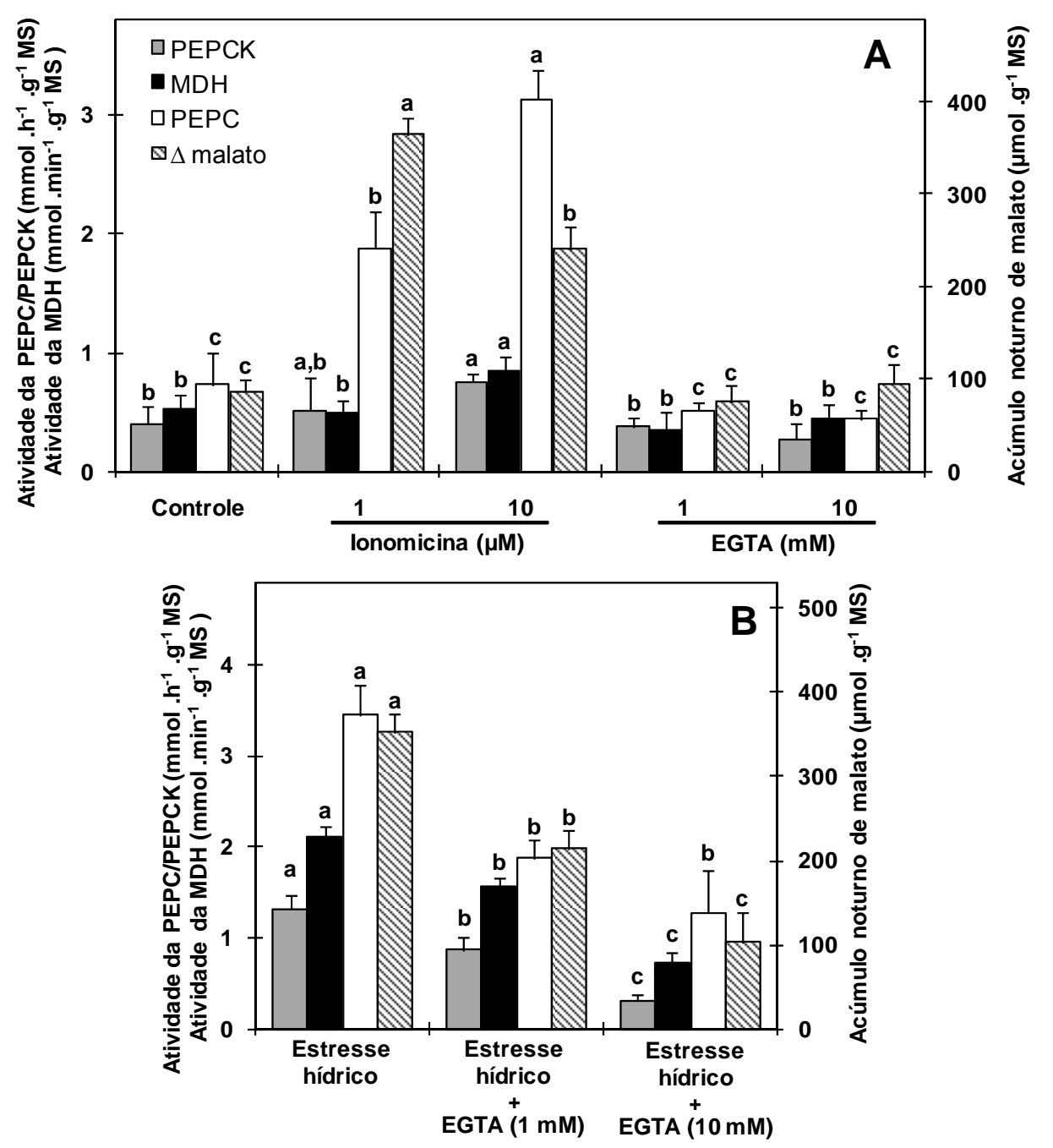

Figura 28. Influência do cálcio citossólico sobre a indução de A. comosus ao CAM em resposta ao estresse hídrico. As plantas foram tratadas com ionomicina (ionóforo de cálcio) ou EGTA (quelante de cálcio extracelular) durante 15 dias na ausência de estresse hídrico (A) ou na presença de estresse hídrico (B). Os valores são a média \pm DP de dois experimentos realizados em triplicata. Barras com a mesma letra não diferem significativamente pelo teste de Tukey $(P<0,05)$.

Tabela 8: Teor relativo de água nas folhas de abacaxizeiro após 15 dias de tratamento com ionomicina ou EGTA na presença ou ausência de estresse hídrico. Valores médios ( \pm DP), $n=15$.

\begin{tabular}{lc}
\hline Tratamento & Teor relativo de água (\%) \\
\hline Controle & $97.7( \pm 1.9) \mathrm{a}$ \\
\hline Ionomicina $(1 \mu \mathrm{M})$ & $96.3( \pm 2.7) \mathrm{a}$ \\
Ionomicina $(10 \mu \mathrm{M})$ & $98.4( \pm 3.1) \mathrm{a}$ \\
EGTA $(1 \mathrm{mM})$ & $97.3( \pm 4.0) \mathrm{a}$ \\
EGTA $(10 \mathrm{mM})$ & $79.2( \pm 3.4) \mathrm{b}$ \\
Estresse hídrico & $58.3( \pm 3.4) \mathrm{c}$ \\
Estresse hídrico + EGTA $(1 \mu \mathrm{M})$ & $57.7( \pm 1.8) \mathrm{c}$ \\
Estresse hídrico + EGTA $(10 \mathrm{mM})$ & $51.2( \pm 2.0) \mathrm{d}$ \\
\hline
\end{tabular}

Médias seguidas da mesma letra não diferem significativamente pelo teste de Tukey $(P<0,05)$. 
Em contrapartida, foi observado que os tratamentos com 1 ou $10 \mathrm{mM}$ de EGTA não afetaram os teores basais de $\Delta$ malato e atividade da PEPC, MDH e PEPCK presentes nas plantas de abacaxizeiro mantidas na ausência de estresse hídrico (Figura 28A), não evidenciando, portanto, que níveis tóxicos desse composto tenham sido atingidos.

Como mostra a Tabela 8, observou-se que o tratamento com 1 mM de EGTA não resultou em alterações consideráveis no teor de água dos tecidos foliares das plantas mantidas na presença ou na ausência de estresse hídrico. Por outro lado, foi constatada uma redução significativa no conteúdo hídrico foliar das plantas submetidas ao tratamento com $10 \mathrm{mM}$ de EGTA tanto na presença quanto na ausência de estresse hídrico (Tabela 8).

Observou-se também que as plantas de abacaxizeiro tratadas com ABA (10 $\mu \mathrm{M})$ na presença de EGTA (1 ou $10 \mathrm{mM}$ ) apresentaram teores de $\Delta$ malato e de atividade da PEPC, MDH e PEPCK bastante reduzida em comparação com as plantas incubadas com esse hormônio na ausência de EGTA (Figura 29). As duas concentrações de EGTA utilizadas apresentaram níveis semelhantes de inibição da expressão do CAM em resposta ao ABA (Figura 29).

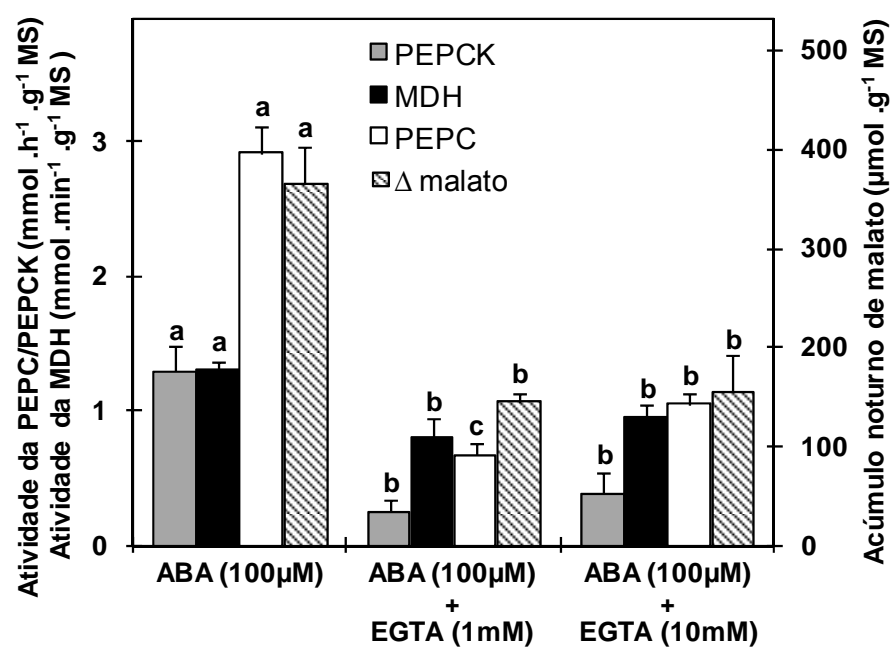

Figura 29. Influência do cálcio citossólico sobre a indução de $A$. comosus ao CAM em resposta ao ácido abscísico. As plantas foram tratadas com EGTA (quelante de cálcio extracelular) durante 15 dias na presença de $100 \mu \mathrm{M}$ de $\mathrm{ABA}(\mathrm{B})$. Os valores mostrados representam a média \pm DP de dois experimentos realizados em triplicata. Barras com a mesma letra não diferem significativamente pelo teste de Tukey $(P<$ $0,05)$. 
Observou-se, ainda, que a aplicação de EGTA (1 ou $10 \mathrm{mM}$ ) resultou em reduções no conteúdo hídrico foliar das plantas de abacaxizeiro (Tabela 9).

Tabela 9: Teor relativo de água nas folhas de abacaxizeiro após 15 dias de tratamento com EGTA ou fluridona na presença ou ausência de ABA $(100 \mu \mathrm{M})$. Valores médios ( $\pm \mathrm{DP}), n=15$.

\begin{tabular}{cc}
\hline Tratamento & Teor relativo de água (\%) \\
\hline $\mathrm{ABA}(100 \mu \mathrm{M})$ & $99.2( \pm 0.5) \mathrm{a}$ \\
$\mathrm{ABA}(100 \mu \mathrm{M})+\mathrm{EGTA}(1 \mathrm{mM})$ & $93.6( \pm 2.4) \mathrm{b}$ \\
$\mathrm{ABA}(100 \mu \mathrm{M})+\mathrm{EGTA}(10 \mathrm{mM})$ & $94.1( \pm 2.9) \mathrm{b}$ \\
\hline Médias seguidas da mesma letra não diferem significativamente pelo teste de Tukey $(\mathrm{P}<0,05)$.
\end{tabular}

\section{IV.8. Influência do óxido nítrico sobre a expressão do CAM em abacaxizeiro}

\section{Tratamentos de suplementação ou remoção de óxido nítrico}

A abordagem inicialmente utilizada para avaliar a influência do óxido nítrico (NO) sobre a expressão do CAM em abacaxizeiro consistiu na realização de tratamentos com compostos doadores desse radical livre tanto na presença quanto na ausência de estresse hídrico. Foram utilizados dois doadores de NO: o nitroprussiato de sódio (SNP) e o 6-(2-hidroxi-1-metil-2-nitroso-hidrazino)-N-metil-1-hexanamina (NOC9), os quais foram aplicados diariamente durante os 15 dias de experimento com o intuito de prolongar a exposição das plantas à presença de NO.

Foi observado que as plantas de abacaxizeiro mantidas na ausência de estresse hídrico e tratadas com $10 \mu \mathrm{M}$ de SNP ou NOC9 apresentaram aumentos consideráveis tanto no $\Delta$ malato quanto nas atividades das três enzimas analisadas (Figura 30A). Já o tratamento com $1 \mu \mathrm{M}$ de SNP também na ausência de estresse hídrico, provocou incrementos significativos apenas na atividade da PEPC (Figura 30A). Por outro lado, constatou-se que as plantas de A. comosus tratadas com SNP ou NOC9 na presença de estresse hídrico não apresentaram alterações significativas no $\Delta$ malato ou nas atividades enzimáticas (Figura 30B), indicando que aplicação desses compostos não induziu incrementos adicionais no nível de expressão do CAM apresentado por essas plantas (Figura 30B). A única diferença significativa observadas nesses experimentos 
consistiu em um aumento de aproximadamente $15 \%$ nos teores de atividade da PEPC nas plantas tratadas com $10 \mu \mathrm{M}$ de SNP (Figura 30B).

Em paralelo, plantas de abacaxizeiro foram submetidas ao tratamento com 10 $\mu \mathrm{M}$ de ferrocianeto de potássio $\left(\mathrm{K}_{4} \mathrm{Fe}(\mathrm{CN})_{6}\right)$, um composto com propriedades químicas similares ao SNP, mas que não apresenta a capacidade de liberar NO quando em solução aquosa, atuando, portanto, como um controle negativo dos experimentos com doadores de $\mathrm{NO}$ (Figura 30). Em geral, foi visto que a aplicação de $\mathrm{K}_{4} \mathrm{Fe}(\mathrm{CN})_{6}$ não desencadeou alterações significativas no $\Delta$ malato ou nas atividades enzimáticas das plantas mantidas na presença ou na ausência de estresse hídrico (Figura 30).
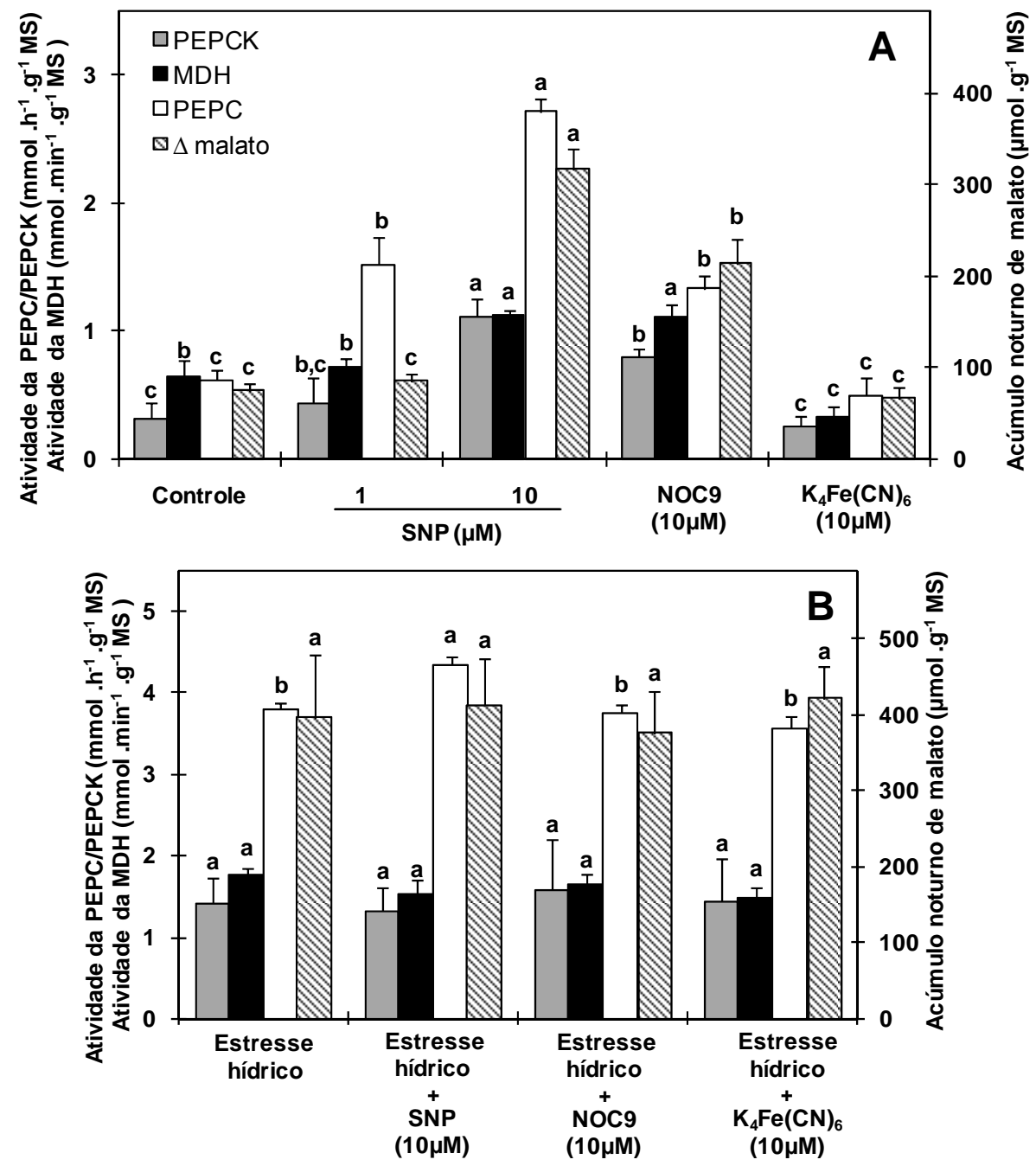

Figura 30. Influência de compostos doadores de óxido nítrico sobre a indução do CAM em abacaxizeiro. As plantas foram tratadas com SNP ou NOC9 (doadores de NO) ou com $\mathrm{K}_{4} \mathrm{Fe}(\mathrm{CN})_{6}$ (controle negativo) durante 15 dias na ausência de estresse hídrico (A) ou na presença de estresse hídrico (B). As aplicações dos doadores de NO foram realizadas diariamente. Os valores são a média \pm DP de experimentos realizados em triplicata. Barras com a mesma letra não diferem significativamente pelo teste de Tukey $(P<0,05)$. 
Constatou-se, também, que os tratamentos com SNP, NOC9 ou $\mathrm{K}_{4} \mathrm{Fe}(\mathrm{CN})_{6}$ não resultaram em variações consideráveis nos teores relativos de água nos tecidos foliares de abacaxizeiro (Tabela 10).

Tabela 10: Teor relativo de água nas folhas de abacaxizeiro após 15 dias de tratamento com SNP, NOC9 ou $\mathrm{K}_{4} \mathrm{Fe}(\mathrm{CN})_{6}$ na presença ou ausência de estresse hídrico. Valores médios ( $\left.\pm \mathrm{DP}\right), n=15$.

\begin{tabular}{lc}
\hline Tratamento & Teor relativo de água (\%) \\
\hline Controle & $97.7( \pm 1.9) \mathrm{a}$ \\
$\mathrm{SNP}(1 \mu \mathrm{M})$ & $96.4( \pm 2.9) \mathrm{a}$ \\
$\mathrm{SNP}(10 \mu \mathrm{M})$ & $95.0( \pm 4.2) \mathrm{a}$ \\
$\mathrm{NOC9}(10 \mu \mathrm{M})$ & $97.4( \pm 1.4) \mathrm{a}$ \\
$\mathrm{K}_{4} \mathrm{Fe}(\mathrm{CN})_{6}(10 \mu \mathrm{M})$ & $98.2( \pm 3.2) \mathrm{a}$ \\
Estresse hídrico & $58.3( \pm 3.4) \mathrm{b}$ \\
Estresse hídrico $+\mathrm{SNP}(10 \mu \mathrm{M})$ & $57.1( \pm 4.7) \mathrm{b}$ \\
Estresse hídrico + NOC9 $(10 \mu \mathrm{M})$ & $60.6( \pm 4.4) \mathrm{b}$ \\
Estresse hídrico + $\mathrm{K}_{4} \mathrm{Fe}(\mathrm{CN})_{6}(10 \mu \mathrm{M})$ & $59.2( \pm 3.4) \mathrm{b}$ \\
\hline
\end{tabular}

Adicionalmente, foram realizadas aplicações de diferentes concentrações de NO gasoso diretamente na atmosfera dos frascos que continham as plantas de abacaxizeiro (Figura 31). Tendo em vista a baixa estabilidade química do NO, as aplicações desse composto foram realizadas diariamente durante o período de 15 dias.

Tal como foi observado nos tratamentos com os doadores de NO, a aplicação de NO gasoso resultou em aumentos consideráveis no $\Delta$ malato e nas atividades da PEPC e MDH das plantas mantidas na ausência de estresse hídrico (Figura 31A). Contudo, as duas concentrações de $\mathrm{NO}$ gasoso utilizadas neste trabalho, 50 e 500 nM, não promoveram incrementos significativos nas atividades da PEPCK (Figura 31A). A aplicação de 500 nM de NO também não provocou alterações significativas no $\Delta$ malato ou nas atividades da PEPC e MDH em plantas mantidas na presença de estresse hídrico, contudo, promoveu um aumento na atividade da PEPCK dessas plantas (Figura 31B). 

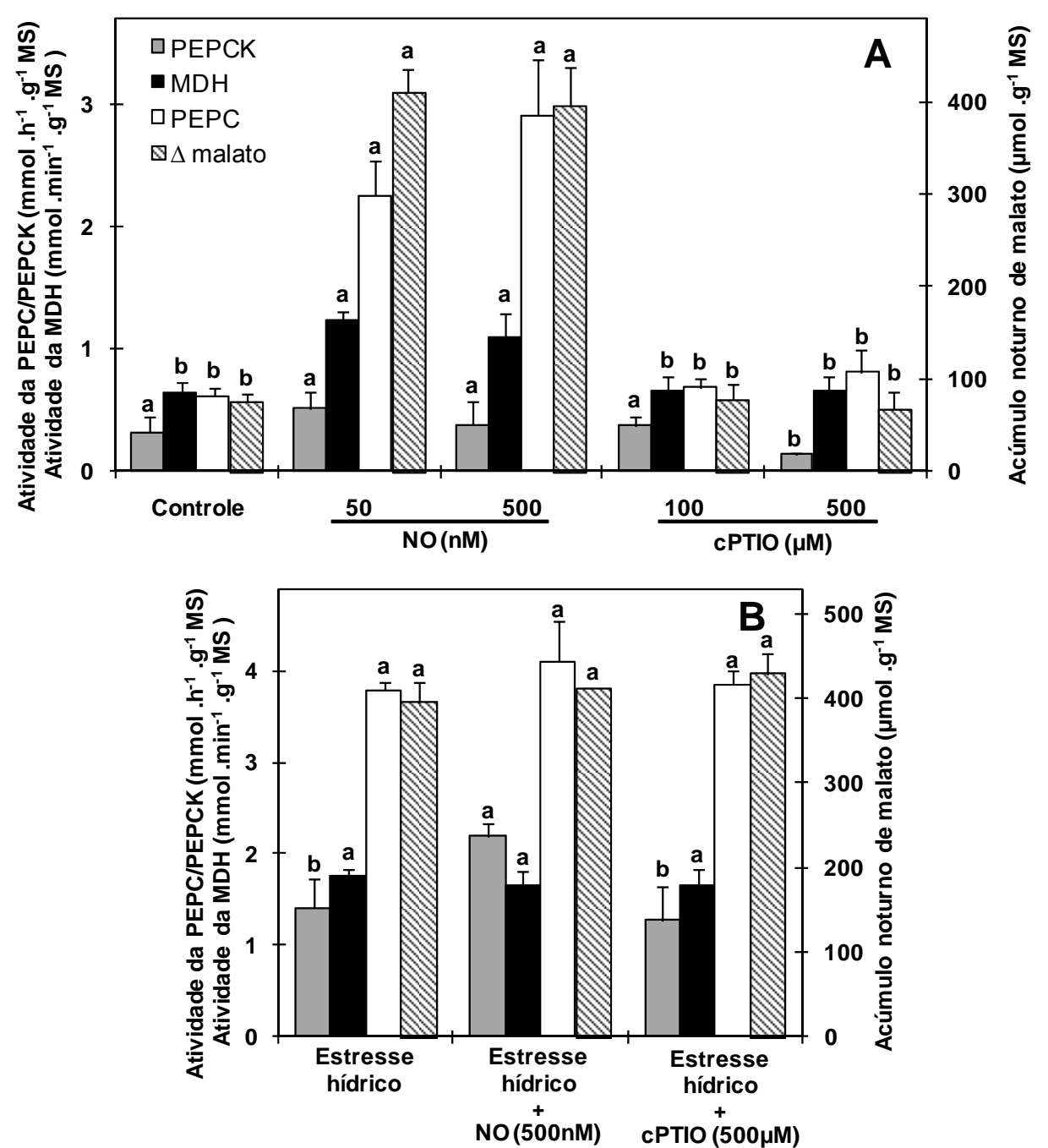

Figura 31. Influência do óxido nítrico sobre a indução do CAM em abacaxizeiro. As plantas foram tratadas durante 15 dias com NO gasoso ou CPTIO (seqüestrador de NO) na ausência de estresse hídrico (A) ou na presença de estresse hídrico (B). As aplicações de NO ou CPTIO foram realizadas diariamente. Os valores mostrados representam a média \pm DP de experimentos realizados em triplicata. Barras com a mesma letra não diferem significativamente pelo teste de Tukey $(P<0,05)$.

Tabela 11: Teor relativo de água nas folhas de abacaxizeiro após 15 dias de tratamento com NO ou cPTIO na presença ou ausência de estresse hídrico. Valores médios ( \pm DP), $n=15$.

\begin{tabular}{lc}
\hline Tratamento & Teor relativo de água (\%) \\
\hline Controle & $97.7( \pm 1.9) \mathrm{a}$ \\
$\mathrm{NO}(50 \mathrm{nM})$ & $98.4( \pm 1.4) \mathrm{a}$ \\
$\mathrm{NO}(500 \mathrm{nM})$ & $94.2( \pm 5.4) \mathrm{a}$ \\
CPTIO $(100 \mu \mathrm{M})$ & $95.4( \pm 4.2) \mathrm{a}$ \\
CPTIO $(500 \mu \mathrm{M})$ & $98.5( \pm 1.2) \mathrm{a}$ \\
Estresse hídrico & $58.3( \pm 3.4) \mathrm{b}$ \\
Estresse hídrico + NO $(500 \mathrm{nM})$ & $51.4( \pm 1.7) \mathrm{c}$ \\
Estresse hídrico + CPTIO $(500 \mu \mathrm{M})$ & $56.4( \pm 5.2) \mathrm{b}, \mathrm{C}$ \\
\hline
\end{tabular}

Médias seguidas da mesma letra não diferem significativamente pelo teste de Tukey $(\mathrm{P}<0,05)$. 
Com o intuito de verificar se o NO atuaria como um mediador da indução do CAM em resposta ao estresse hídrico, foram realizados tratamentos com 100 ou $500 \mu \mathrm{M}$ de cPTIO (2-(4-carboxifenil)-4,4,5,5,-tetrametilimidazolina-1-oxil-3-oxido), um seqüestrador de NO, tanto na presença quanto na ausência de estresse hídrico. A solução contendo o CPTIO foi renovada diariamente, a fim de prolongar o contato das plantas com essa substância.

De modo geral, os valores de $\Delta$ malato e de atividades enzimáticas detectados nas plantas tratadas com cPTIO na ausência de estresse hídrico não foram significativamente diferentes daqueles detectados nas plantas controle, exceto por uma redução na atividade da PEPCK das plantas tratadas com $500 \mu \mathrm{M}$ desse seqüestrador de NO (Figura 31A). Da mesma forma, verificou-se que os tratamentos com cPTIO também não alteraram os valores de $\Delta$ malato e de atividade da PEPC, MDH e PEPCK em plantas de abacaxizeiro expostas à condição de estresse hídrico (Figura 31B).

O conteúdo hídrico foliar das plantas de abacaxizeiro também não foi afetado pelas concentrações de NO ou cPTIO empregadas no presente estudo (Tabela 11).

\section{Produção de NO durante a indução do CAM}

As análises realizadas por meio da técnica de quimiluminescência revelaram que a partir do $2^{\circ}$ dia de tratamento os teores de emissão de NO nas plantas expostas ao estresse hídrico foram, de modo geral, superiores àqueles detectados nas plantas controle (Figura 32). Observou-se, ainda, um pico de emissão de NO no $4^{\circ}$ dia após a transferência das plantas para o tratamento de estresse hídrico, o qual ultrapassou em cerca de 4 vezes os teores detectados nas plantas controle no mesmo momento de análise. Por outro lado, no $8^{\circ}$ dia de tratamento, as plantas expostas ao estresse hídrico apresentaram uma redução considerável na taxa de emissão de NO. Após o $15^{\circ}$ dia de tratamento, observou-se uma tendência de diminuição nos valores de emissão de NO 
pelas plantas expostas ao estresse hídrico, contudo, estes ainda se mantiveram superiores aos observados na condição controle (Figura 32).

As plantas controle, por sua vez, apresentaram variações pouco pronunciadas nos teores de emissão de NO durante o período analisado, exceto por uma tendência de aumento entre $\circ 3^{\circ}$ e $5^{\circ}$ dias de tratamento (Figura 32).

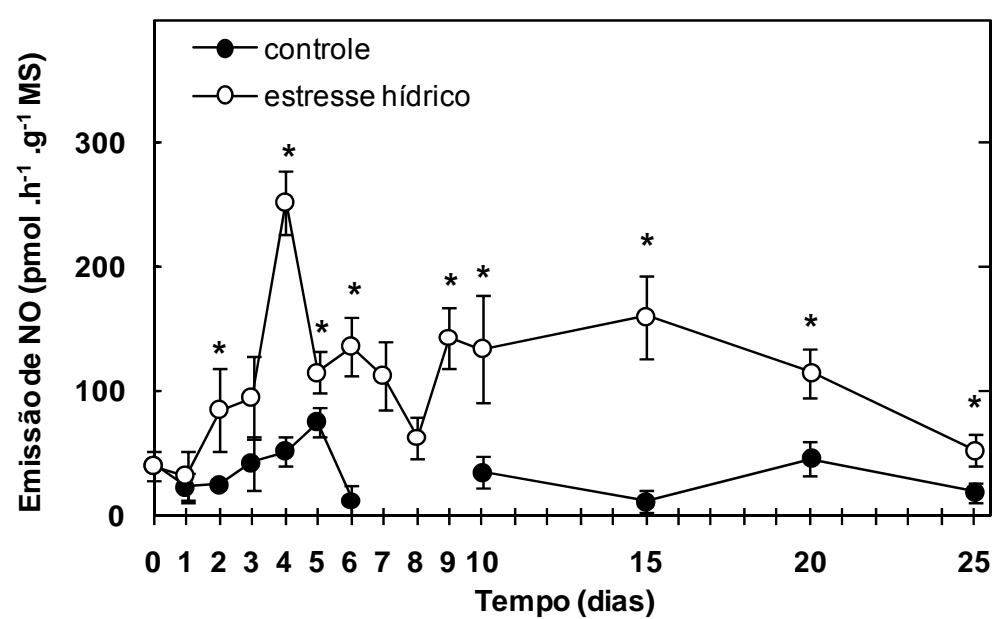

Figura 32. Teores de emissão de NO em abacaxizeiro durante a indução do CAM por estresse hídrico. Os valores mostrados representam a média $\pm \mathrm{DP}$ de experimentos realizados em duplicata. As amostras referentes ao $7^{\circ}, 8^{\circ}, 9^{0}$ dias de controle não foram quantificadas. ${ }^{*}, \mathrm{P}<0,05$, Teste $\mathrm{t}$, representando diferença significativa entre plantas na condição controle e aquelas submetidas ao estresse hídrico.

Também foram realizadas determinações in situ da produção de NO em tecidos foliares de abacaxizeiro durante o período que compreende a indução do CAM por estresse hídrico. Para tanto, empregou-se marcador 4,5 diaminofluoresceína diacetato (DAF-2DA), o qual é capaz de se difundir facilmente para o interior das células vegetais e ao reagir com as formas oxidadas do NO emite fluorescência verde esmeralda. Essas análises in situ da produção de NO foram realizadas tanto por microscopia de fluorescência (Figuras 33 a 39) quanto por microscopia confocal (Figuras 40 a 42).

No caso das análises por microscopia de fluorescência, todos os cortes histológicos foram observados antes e após a incubação com o marcador DAF-2DA, a fim de permitir uma distinção entre a autofluorescência natural do tecido foliar de abacaxizeiro e aquela oriunda da marcação do NO. Esse cuidado permitiu constatar que os comprimentos de onda de emissão (450 nm) e excitação (515 nm) empregados para 
essas análises resultaram em uma intensa autofluorescência dos cloroplastos em vermelho e também uma fraca autofluorescência verde dos feixes vasculares e fibras (Figuras 33 a 39, fotos C e D). Assim sendo, para discussão dos resultados obtidos por essa técnica analítica, apenas foram considerados como indícios da presença do NO aquelas marcações em fluorescência verde que surgiram após a incubação com o DAF2DA (Figuras 33 a 39, fotos E e F).

Por outro lado, nas análises realizadas por microscopia confocal foi possível eliminar a autofluorescência do tecido nas condições utilizadas para a visualização da marcação do NO pelo DAF-2DA (excitação de 488nm e emissão de 505-530nm) e, dessa forma, toda a fluorescência verde observada ao longo das análises foi atribuída à detecção do NO (Figuras 40 a 42).

De modo geral, as duas técnicas de microscopia forneceram resultados bastante semelhantes. Foi possível observar que, independente do tratamento analisado, a produção de NO nos tecidos foliares de abacaxizeiro esteve localizada principalmente nas células do parênquima clorofilado, em células epidérmicas, tricomas e, menos freqüentemente, nos feixes vasculares (Figuras 33 a 42). Outras regiões foliares como, por exemplo, parênquima aqüífero e fibras, não apresentaram marcação conspícua da produção de $\mathrm{NO}$ em todas as condições ensaiadas (Figuras 33 a 42).

Embora a distribuição espacial da marcação do NO nos tecidos foliares de $A$. comosus tenha sido muito similar entre todos os tratamentos analisados, constatou-se diferenças marcantes no que tange à intensidade de detecção desse radical livre. A produção de NO nos tecidos foliares das plantas mantidas na condição controle se manteve relativamente baixa e pouco variável ao longo dos 25 dias de tratamento, como indicado pela fraca intensidade de fluorescência verde observada na maioria dos cortes incubados com DAF-2DA e visualizados por microscopia de fluorescência (Figura 33 a 38, fotos E) ou confocal (Figuras 40 a 42, fotos A e B).

Tal como constatado nas análises de emissão de NO por quimiluminescência (Figura 32), também se verificou um aumento substancial na detecção in situ da 
produção desse radical livre nos tecidos foliares das plantas expostas ao estresse hídrico, o qual ocorreu em função de incrementos tanto na proporção de células marcadas quanto na intensidade da fluorescência emitida por essas células (Figura 33 a 38, fotos F; Figuras 40 a 42, fotos C e D). Chama a atenção o fato de que essa elevação na produção de NO parece ter iniciado precocemente, uma vez que foi possível detectar aumentos consideráveis na proporção de células marcadas já a partir do $3^{\circ}$ dia de incubação das plantas na presença de estresse hídrico (Figura 33, foto F). As amostras analisadas 1 ou 2 dias após o início do tratamento de estresse hídrico apresentaram níveis de marcação do NO semelhantes aos constatados nas amostras da condição controle (dados não mostrados). De modo geral, o aumento na produção de NO observado nos tecidos foliares das plantas submetidas ao estresse hídrico restringiu-se principalmente às células do parênquima clorofilado e, menos freqüentemente, às células epidérmicas (Figura 33 a 38, fotos F; Figuras 40 a 42, fotos C e D).

Ao longo das análises in situ da produção de NO, também foram realizados controles negativos da marcação desse radical livre. Para tanto, amostras de tecido foliar de plantas de abacaxizeiro foram incubadas em cPTIO por 30 minutos antes de serem tratadas com o indicador DAF-2DA. As análises dessas amostras por microscopia de fluorescência (Figura 39, fotos E e F) ou confocal (Figuras 40 a 42, fotos E e F) revelaram a presença de pouca ou nenhuma fluorescência verde, indicando uma especificidade bastante satisfatória para a detecção do NO. 
Controle (3 dias)

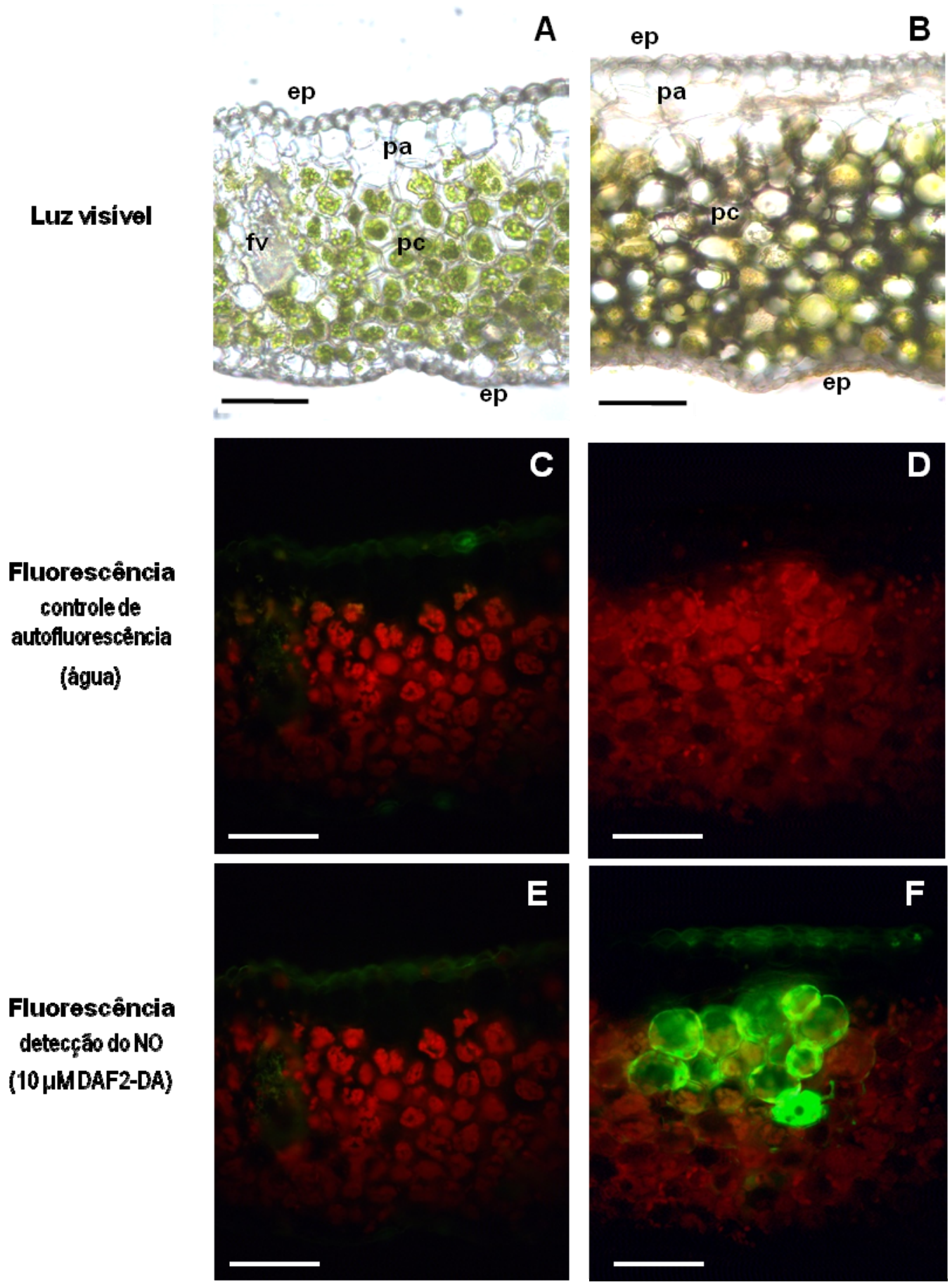

Figura 33. Análise da produção in situ de NO, por microscopia de fluorescência, em folhas de $A$. comosus após 3 dias na condição controle ( $\mathbf{A}, \mathbf{C}$ e E) ou em estresse hídrico (B, D e F). Primeiramente, os cortes incubados apenas na presença de água foram analisados sob luz visível (A e B) ou em fluorescência (450 $\mathrm{nm}$ de excitação e $515 \mathrm{~nm}$ de emissão) (C e D). A seguir, esses cortes foram incubados com $10 \mu \mathrm{M}$ de DAF-2DA durante 30 minutos e novamente analisados em fluorescência (E e F). As emissões de fluorescência esverdeada e vermelha indicam, respectivamente, a produção de NO e a autofluorescência dos cloroplastos. As imagens são representativas de experimentos realizados em triplicata. Legenda: ep, epiderme; pa, parênquima aqüífero; pc, parênquima clorofilado; fv, feixe vascular. Barra = $100 \mu \mathrm{m}$. 


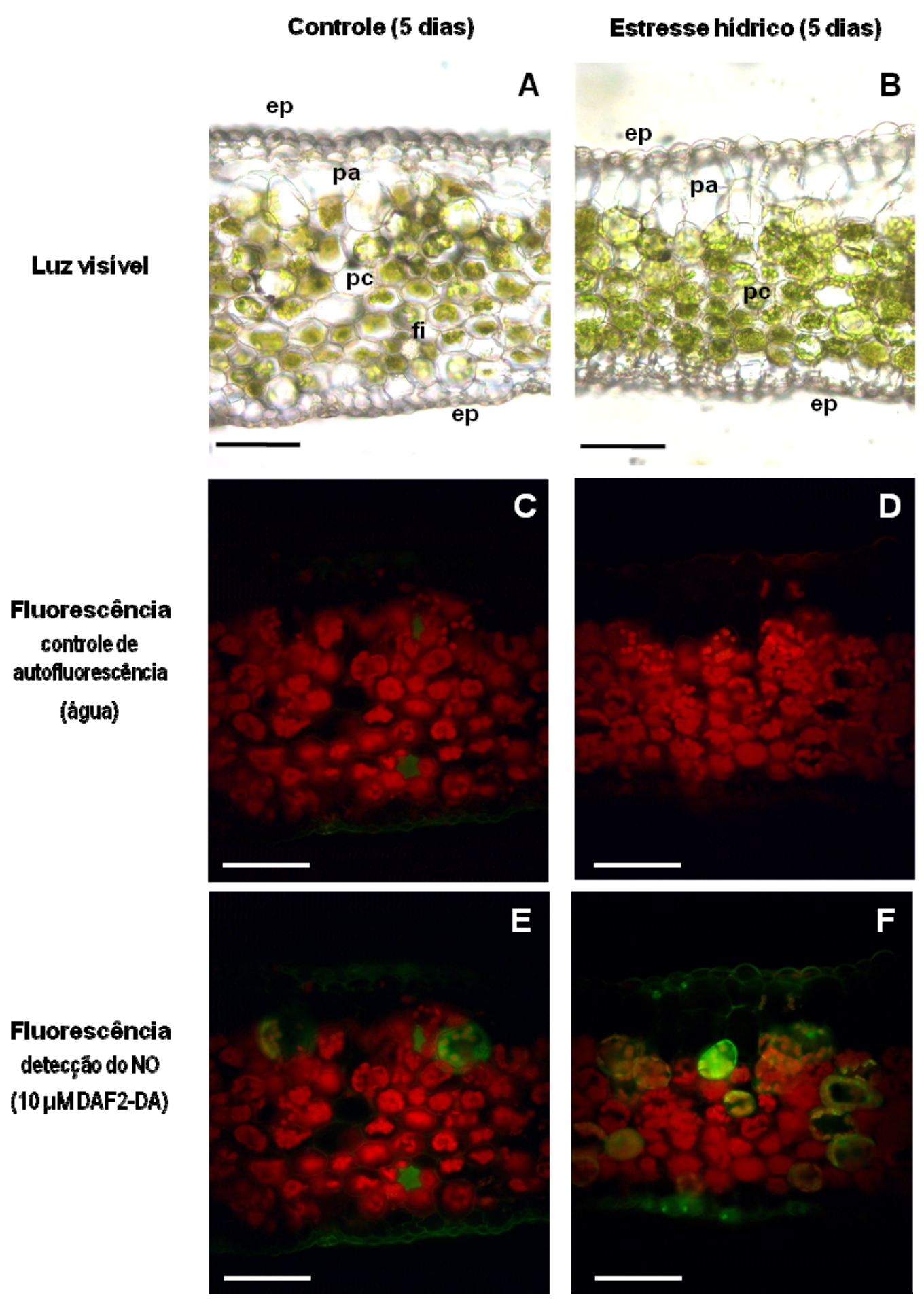

Figura 34. Análise da produção in situ de NO, por microscopia de fluorescência, em folhas de $A$. comosus após 5 dias na condição controle (A, C e E) ou em estresse hídrico (B, D e F). As condições de análise foram iguais as da Figura 33. As emissões de fluorescência esverdeada e vermelha indicam, respectivamente, a produção de NO e a autofluorescência dos cloroplastos. As imagens são representativas de dois experimentos realizados em triplicata. Legenda: ep, epiderme; pa, parênquima aqüífero; pc, parênquima clorofilado; fi, fibras. Barra $=100 \mu \mathrm{m}$. 


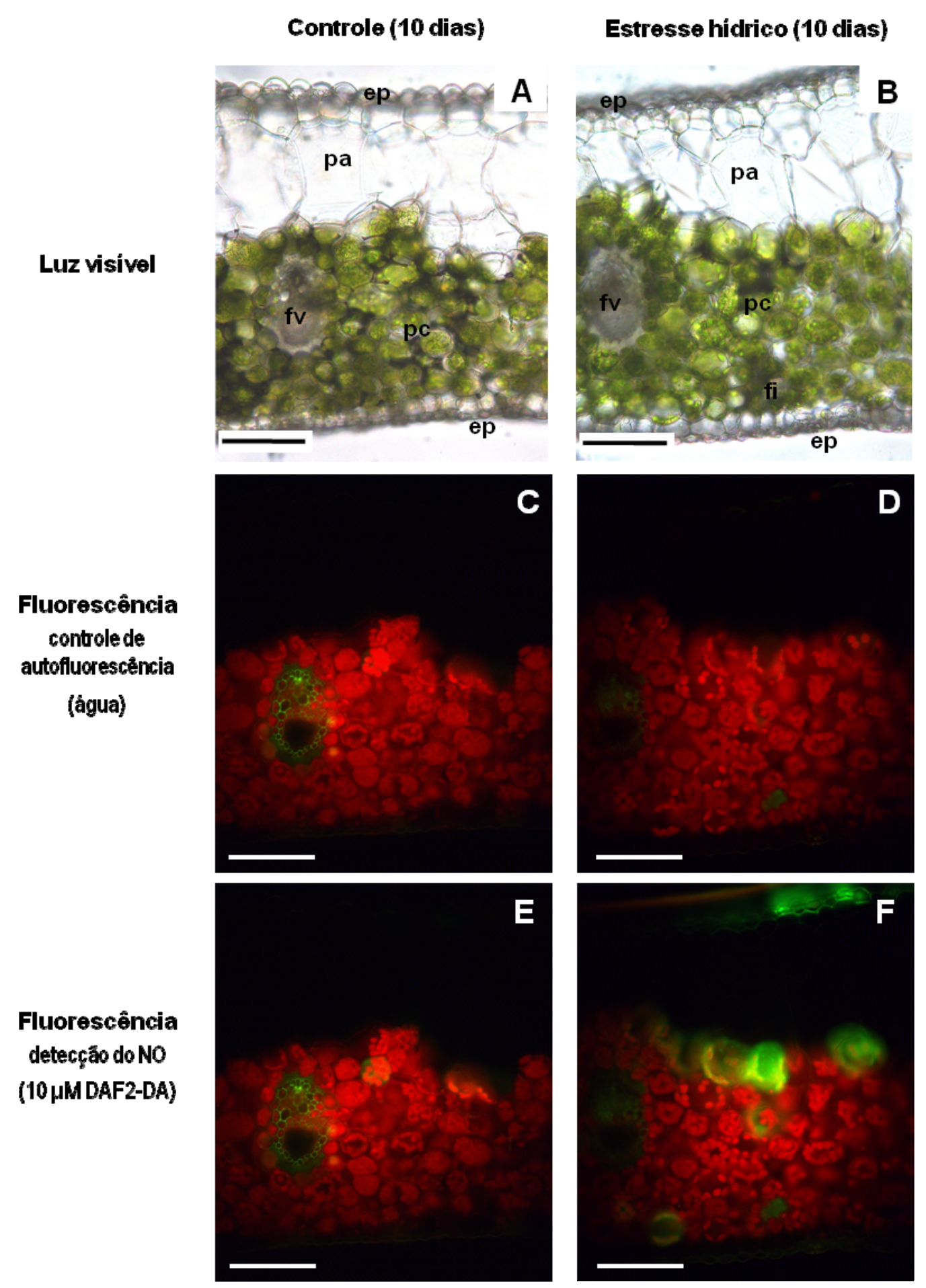

Figura 35. Análise da produção in situ de NO, por microscopia de fluorescência, em folhas de A. comosus após 10 dias na condição controle (A, C e E) ou em estresse hídrico (B, D e F). As condições de análise foram iguais as da Figura 33. As emissões de fluorescência esverdeada e vermelha indicam, respectivamente, a produção de NO e a autofluorescência dos cloroplastos. As imagens são representativas de dois experimentos realizados em triplicata. Legenda: ep, epiderme; pa, parênquima aqǘfero; pc, parênquima clorofilado; fv, feixe vascular; fi, fibras. Barra $=100 \mu \mathrm{m}$. 


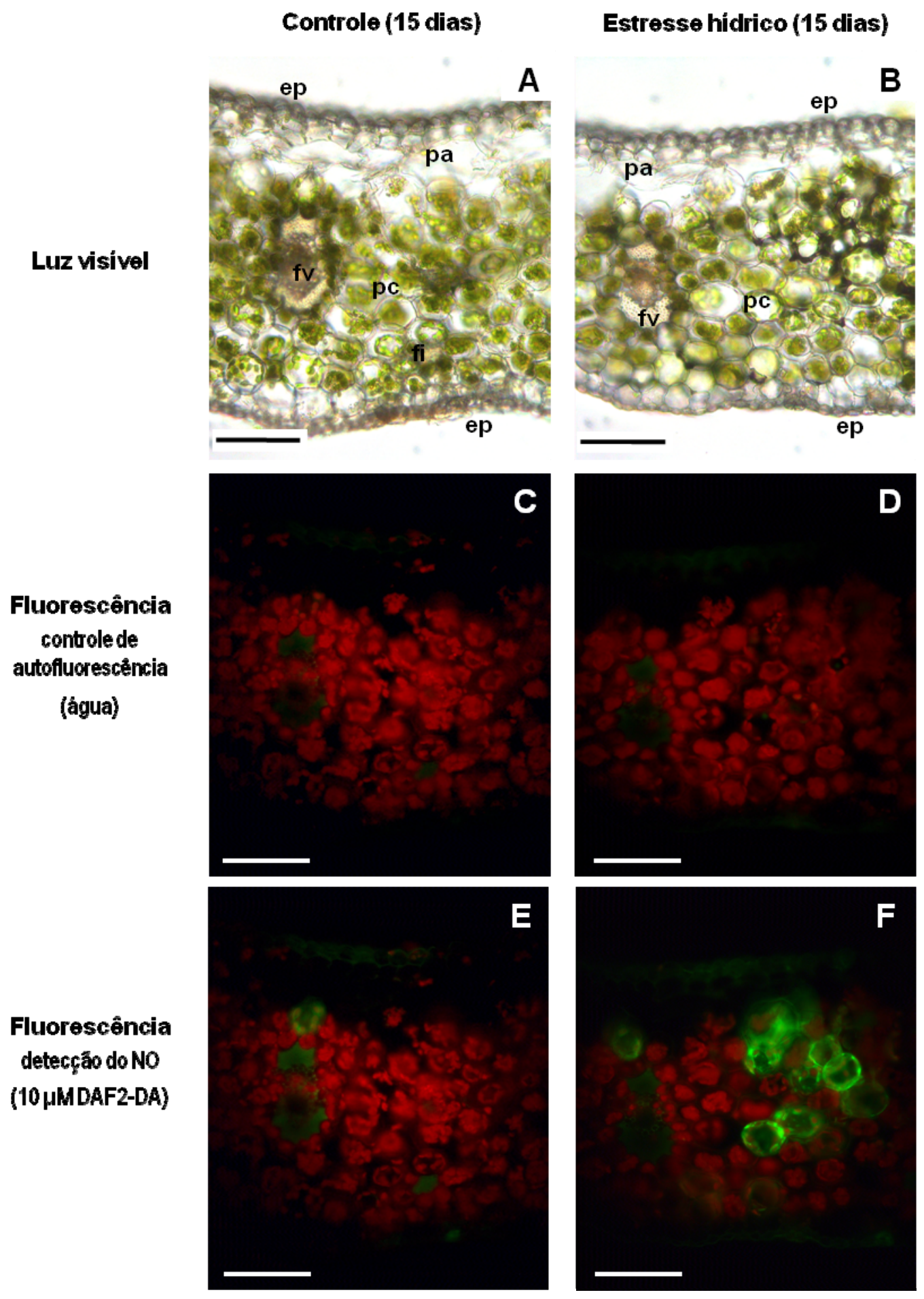

Figura 36. Análise da produção in situ de NO, por microscopia de fluorescência, em folhas de A. comosus após 15 dias na condição controle (A, C e E) ou em estresse hídrico (B, D e F). As condições de análise foram iguais as da Figura 33. As emissões de fluorescência esverdeada e vermelha indicam, respectivamente, a produção de NO e a autofluorescência dos cloroplastos. As imagens são representativas de dois experimentos realizados em triplicata. Legenda: ep, epiderme; pa, parênquima aqüífero; pc, parênquima clorofilado; fv, feixe vascular; fi, fibras. Barra $=100 \mu \mathrm{m}$. 


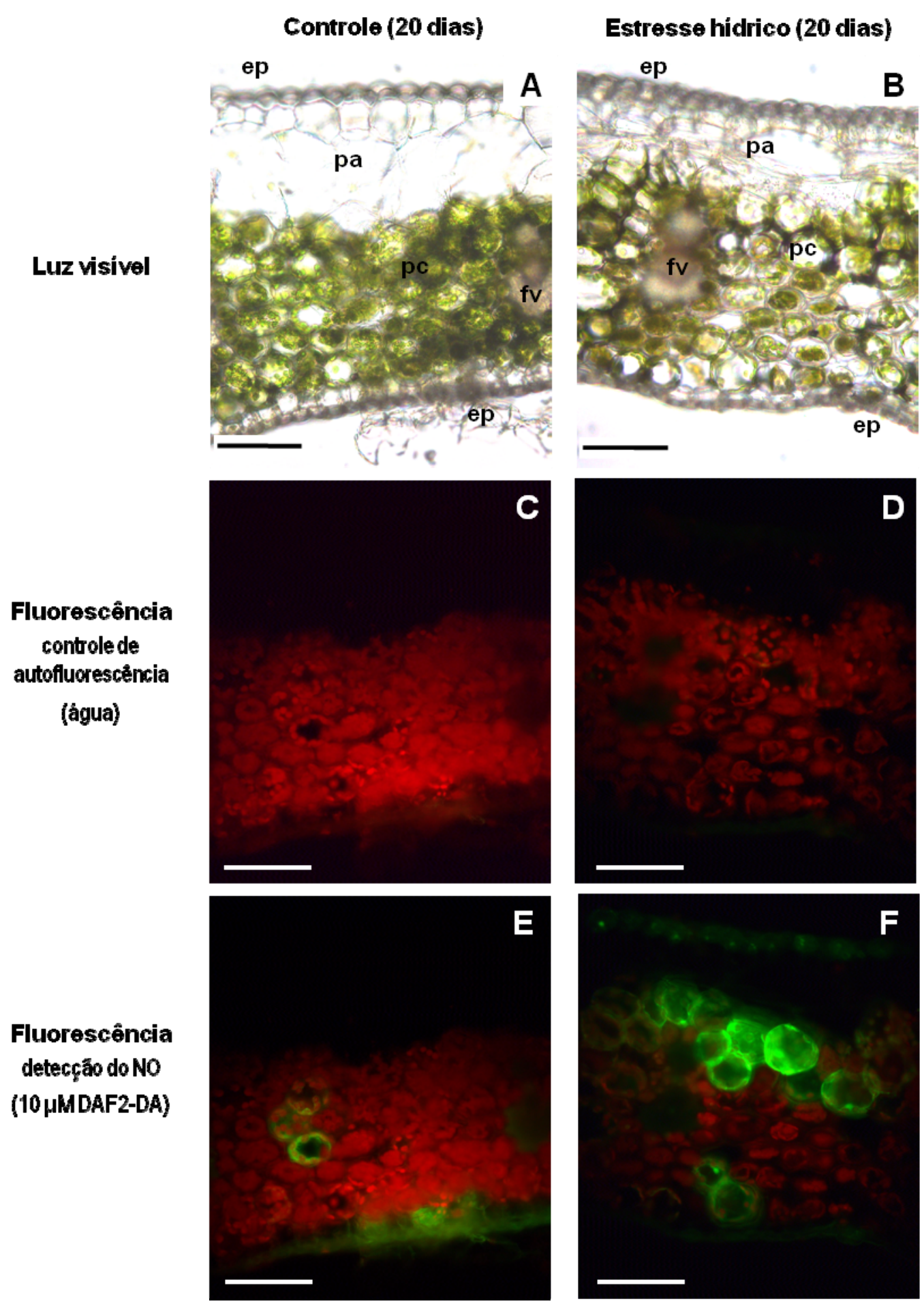

Figura 37. Análise da produção in situ de NO, por microscopia de fluorescência, em folhas de $A$. comosus após 20 dias na condição controle (A, C e E) ou em estresse hídrico (B, D e F). As condições de análise foram iguais as da Figura 33. As emissões de fluorescência esverdeada e vermelha indicam, respectivamente, a produção de NO e a autofluorescência dos cloroplastos. As imagens são representativas de dois experimentos realizados em triplicata. Legenda: ep, epiderme; pa, parênquima aqüífero; pc, parênquima clorofilado; fv, feixe vascular. Barra $=100 \mu \mathrm{m}$. 


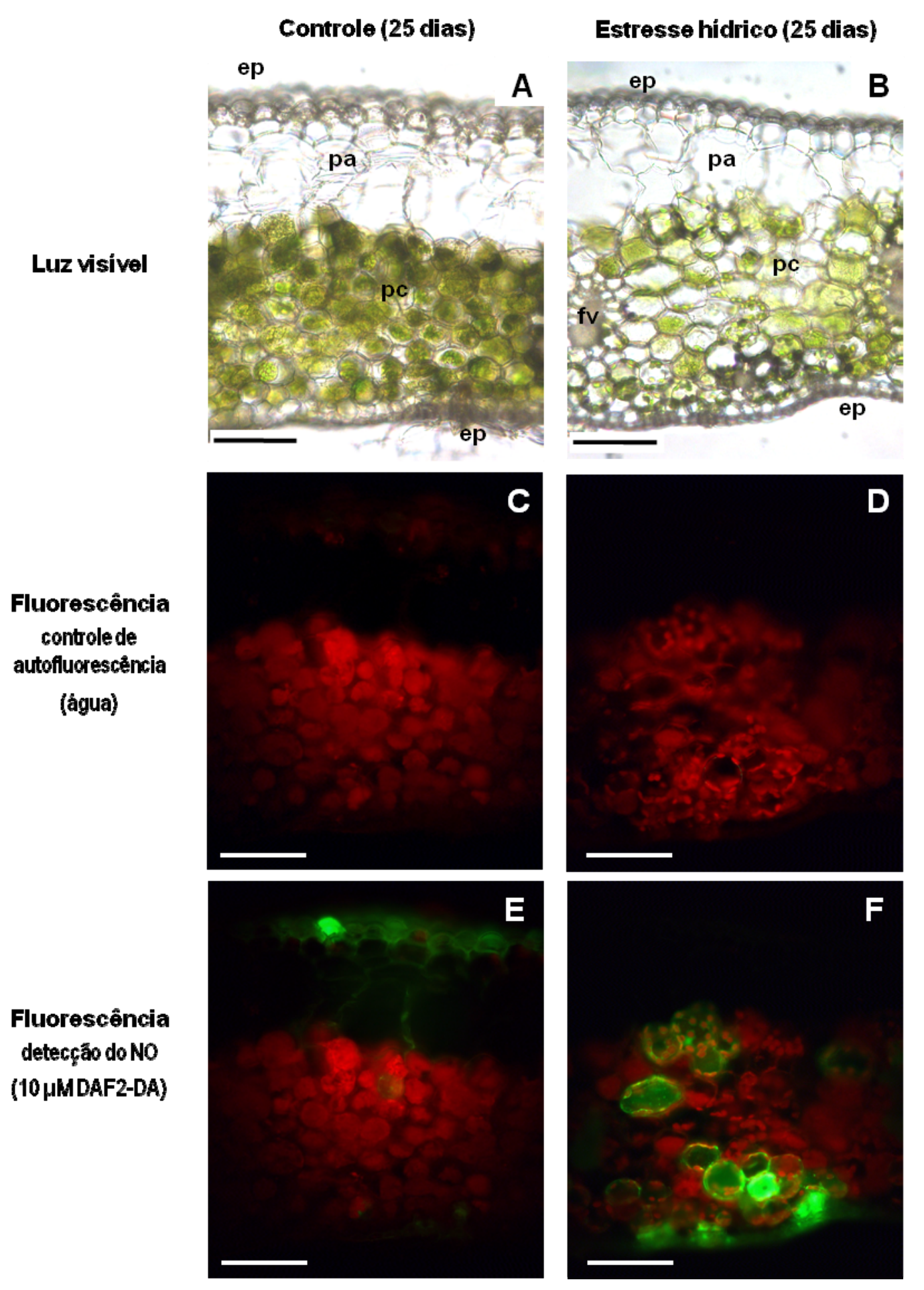

Figura 38. Análise da produção in situ de NO, por microscopia de fluorescência, em folhas de A. comosus após 25 dias na condição controle (A, C e E) ou em estresse hídrico (B, D e F). As condições de análise foram iguais as da Figura 33. As emissões de fluorescência esverdeada e vermelha indicam, respectivamente, a produção de NO e a autofluorescência dos cloroplastos. As imagens são representativas de dois experimentos realizados em triplicata. Legenda: ep, epiderme; pa, parênquima aqüífero; pc, parênquima clorofilado; fv, feixe vascular. Barra $=100 \mu \mathrm{m}$. 


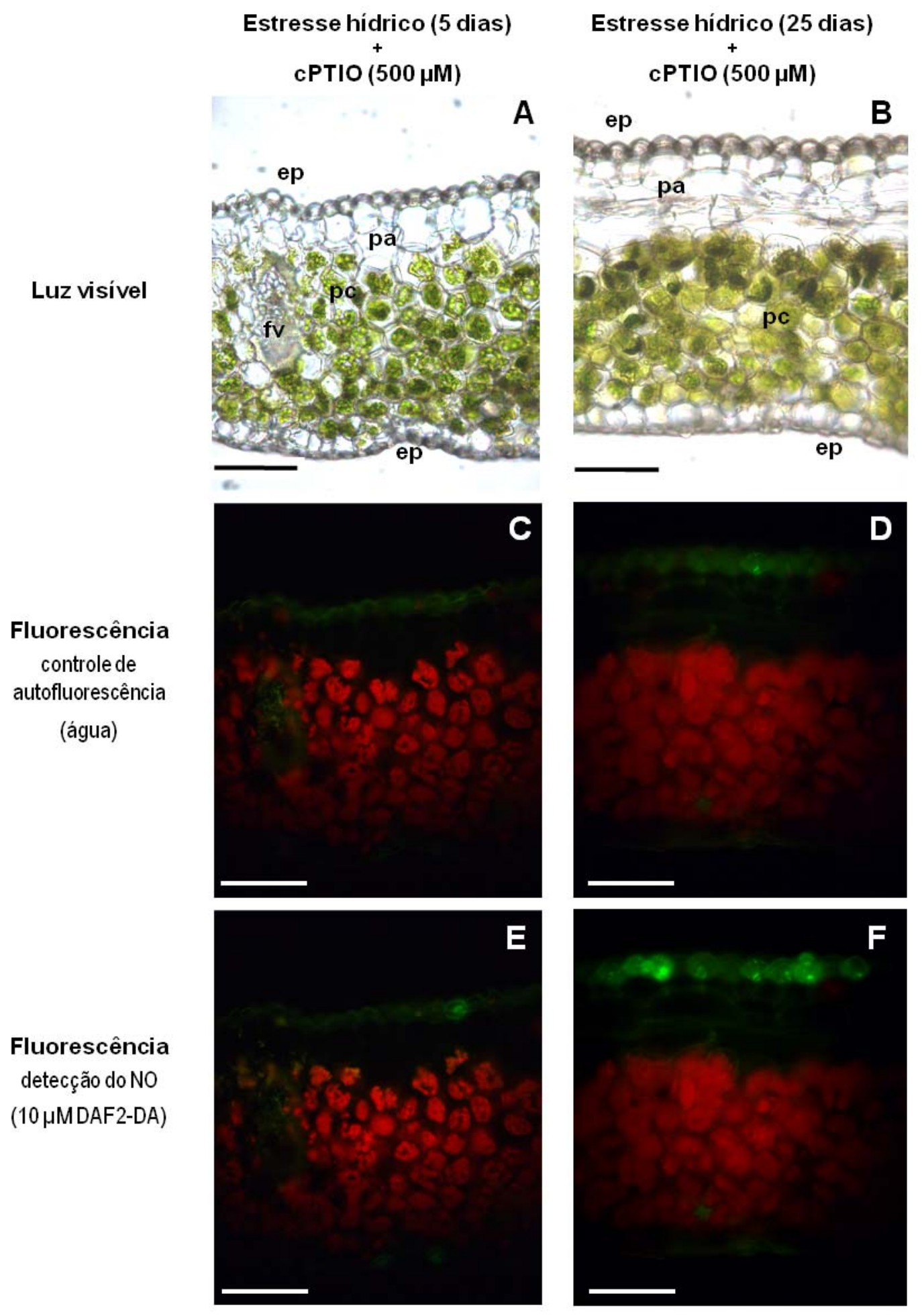

Figura 39. Visualização por microscopia de fluorescência dos controles negativos da análise in situ da produção de $\mathrm{NO}$ em folhas de $A$. comosus após 5 e 25 dias de tratamento com estresse hídrico. Os cortes foram primeiramente incubados por 30 minutos em $500 \mu \mathrm{M}$ de cPTIO (seqüestrador de NO) e analisados sob luz visível (A e B) ou em fluorescência nas faixas de $450 \mathrm{~nm}$ de excitação e $515 \mathrm{~nm}$ de emissão (C e D). A seguir, esses cortes foram incubados com $10 \mu \mathrm{M}$ de DAF-2DA durante 30 minutos e novamente analisados em fluorescência (E e F). As emissões de fluorescência esverdeada e vermelha indicam, respectivamente, a produção de NO e a autofluorescência dos cloroplastos. Legenda: ep, epiderme; pa, parênquima aqüífero; pc, parênquima clorofilado; fv, feixe vascular. Barra $=100 \mu \mathrm{m}$. 


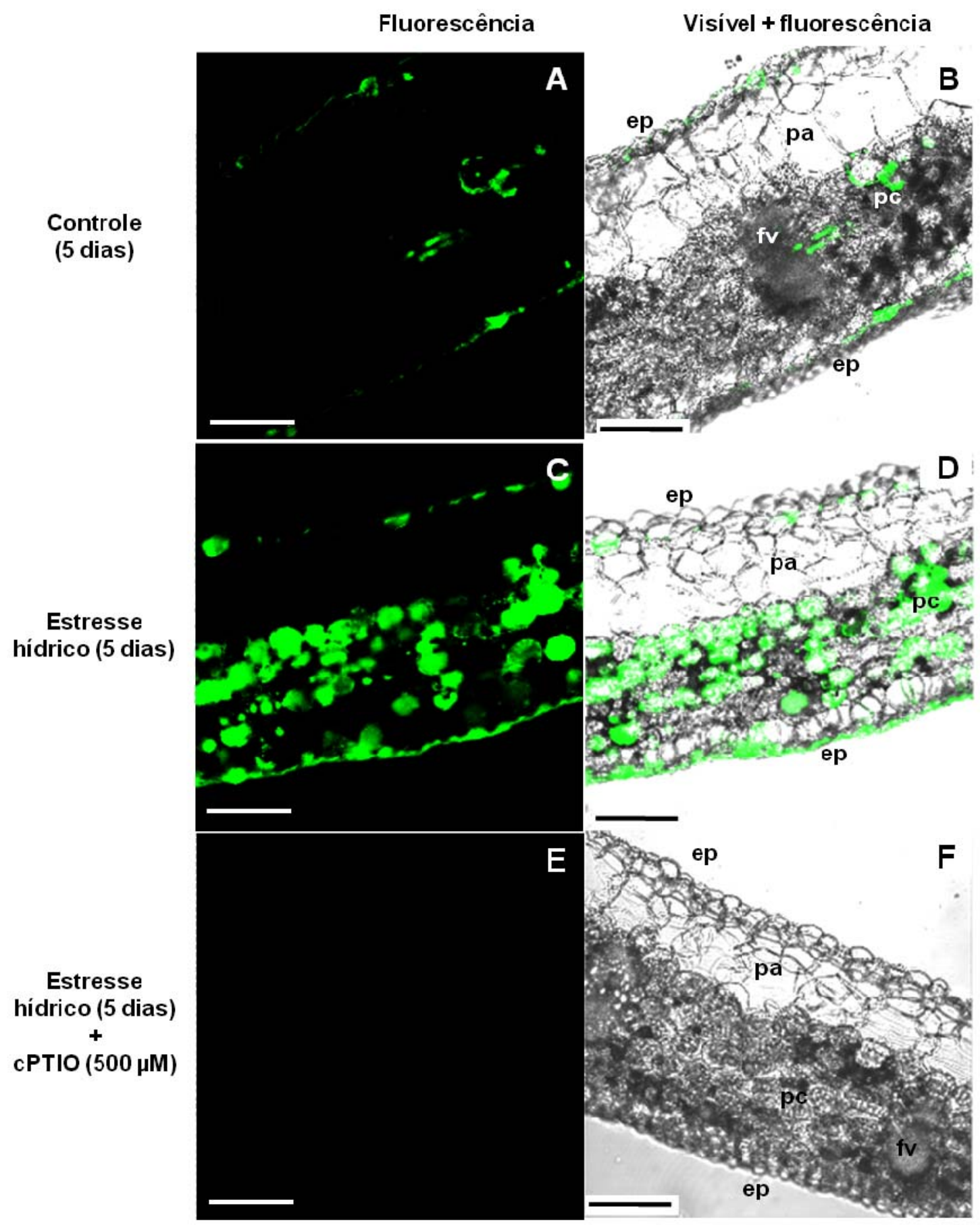

Figura 40. Análise da produção in situ de NO, por microscopia confocal, em folhas de A. comosus após 5 dias na condição controle ou em estresse hídrico. Os cortes foram incubados com $10 \mu \mathrm{M}$ de DAF-2DA e analisados nas faixas de excitação de $488 \mathrm{~nm}$ e emissão de 505-530 nm (A e C). Em E e F, as amostras foram pré-tratadas com cPTIO $(500 \mu \mathrm{M})$ por 30 minutos, antes da incubação por 1 hora com DAF-2DA. Em B, D e F está representada a sobreposição da imagem em luz visível e a marcação do NO. A emissão de fluorescência esverdeada indica a produção de NO. As imagens são representativas de dois experimentos realizados em triplicata. Legenda: ep, epiderme; pa, parênquima aqüífero; pc, parênquima clorofilado; fv, feixe vascular. Barra $=100 \mu \mathrm{m}$. 


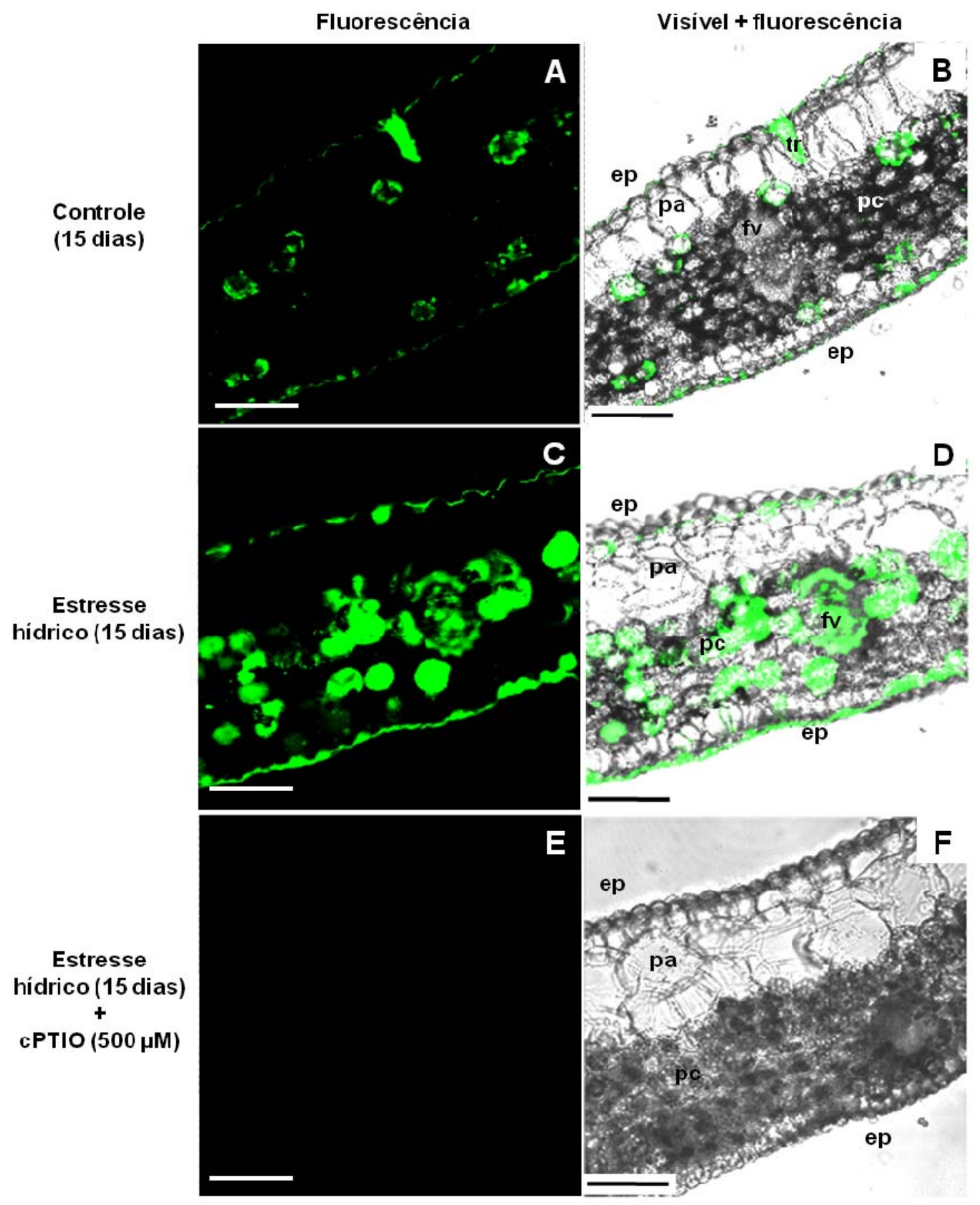

Figura 41. Análise da produção in situ de NO, por microscopia confocal, em folhas de $A$. comosus após 15 dias na condição controle ou em estresse hídrico. Os cortes foram incubados com $10 \mu \mathrm{M}$ de DAF-2DA e analisados nas faixas de excitação de $488 \mathrm{~nm}$ e emissão de 505-530 nm (A e C). Em E e F, as amostras foram pré-tratadas com CPTIO $(500 \mu \mathrm{M})$ por 30 minutos, antes da incubação por 1 hora com DAF-2DA. Em B, D e F está representada a sobreposição da imagem em luz visível e a marcação do NO. A emissão de fluorescência esverdeada indica a produção de NO. As imagens são representativas de dois experimentos realizados em triplicata. Legenda: ep, epiderme; pa, parênquima aqüífero; pc, parênquima clorofilado; fv, feixe vascular; tr, tricoma. Barra $=100 \mu \mathrm{m}$. 


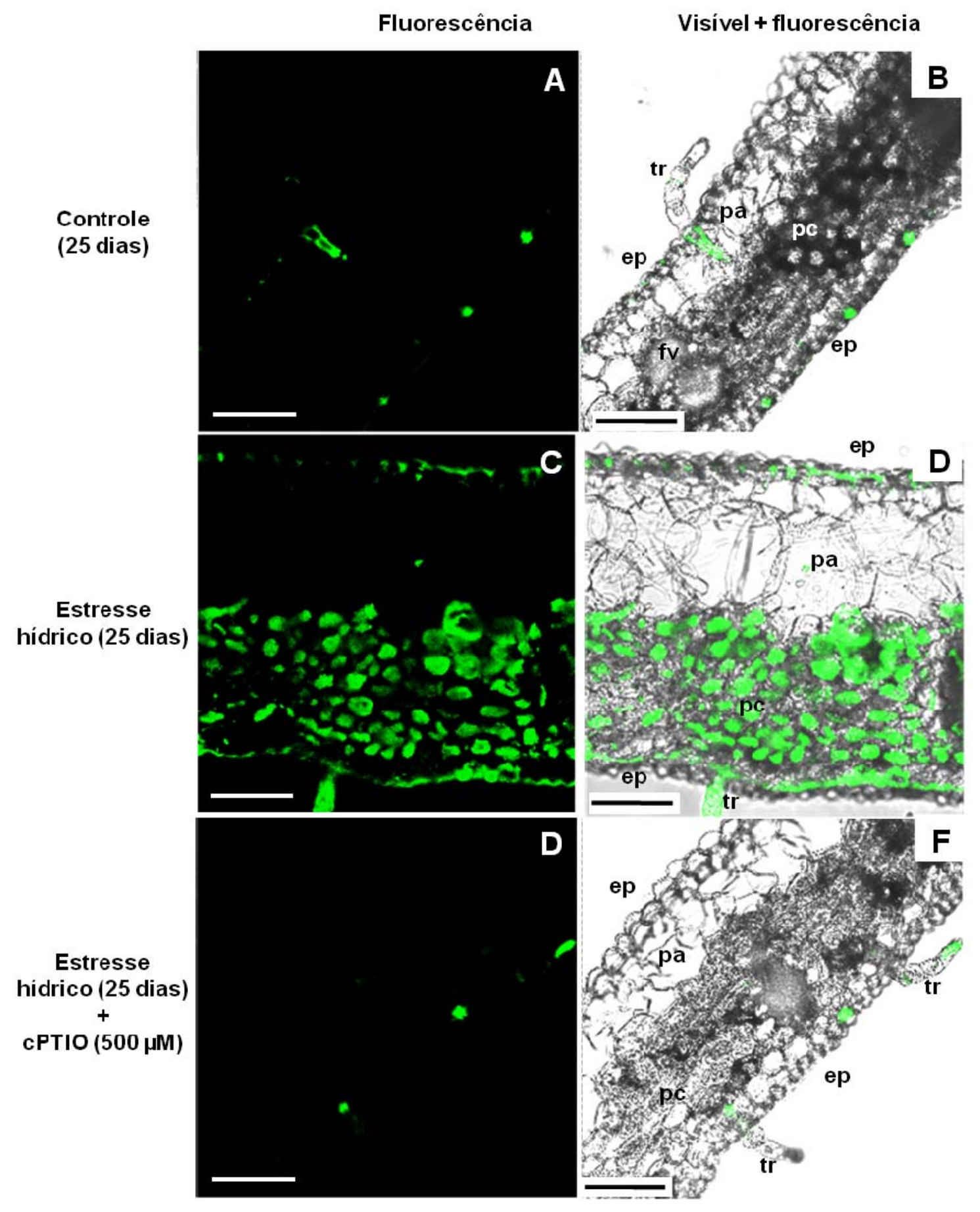

Figura 42. Análise da produção in situ de NO, por microscopia confocal, em folhas de $A$. comosus após 25 dias na condição controle ou em estresse hídrico. Os cortes foram incubados com $10 \mu \mathrm{M}$ de DAF-2DA e analisados nas faixas de excitação de $488 \mathrm{~nm}$ e emissão de 505-530 nm (A e C). Em E e F, as amostras foram pré-tratadas com CPTIO $(500 \mu \mathrm{M})$ por 30 minutos, antes da incubação por 1 hora com DAF-2DA. Em B, D e F está representada a sobreposição da imagem em luz visível e a marcação do NO. A emissão de fluorescência esverdeada indica a produção de NO. As imagens são representativas de dois experimentos realizados em triplicata. Legenda: ep, epiderme; pa, parênquima aqüífero; pc, parênquima clorofilado; fv, feixe vascular; fi, fibras; fv, feixe vascular; tr, tricoma. Barra $=100 \mu \mathrm{m}$. 


\section{Produção de NO durante a reversão do CAM}

Como mostra a Figura 43, os teores de emissão de NO observados nas plantas submetidas à reversão do CAM foram bastante similares àqueles detectados nas plantas mantidas continuamente na condição controle. Constatou-se que tanto as plantas da condição controle quanto aquelas submetidas à reversão do CAM apresentaram uma tendência de redução na emissão de $\mathrm{NO}$ a partir do $10^{\circ}$ dia de experimento (Figura 43). Os teores de emissão de NO nas plantas do tratamento de reversão do CAM foram estatisticamente superiores aos das plantas controle apenas no tempo 0 e após 5 dias tratamento (Figura 43).

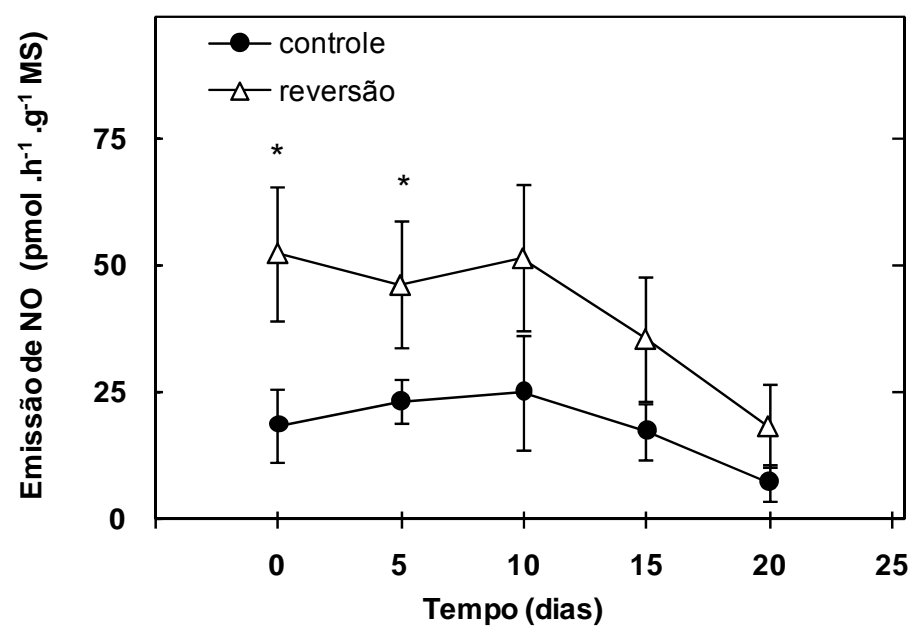

Figura 43. Teores de emissão de óxido nítrico em plantas abacaxizeiro durante a reversão da fotossíntese CAM para $\mathrm{C}_{3}$. As condições dos tratamentos foram iguais as da Figura 9. As amostras referentes ao $25^{\circ}$ dia de tratamento não foram quantificadas. Os valores mostrados representam a média \pm DP de experimentos realizados em triplicata. * $\mathrm{P}<0,05$, Teste $t$, representando diferença significativa entre a condição controle e 0 tratamento de reversão do CAM.

\section{IV.9 Interação entre NO, ABA e $\mathrm{Ca}^{2+}$ citossólico na indução do CAM em abacaxizeiro}

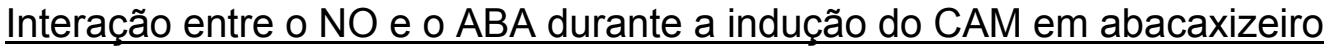

No presente estudo, foram realizados experimentos para verificar a existência de possíveis interações entre o NO e o ABA durante a indução do CAM em abacaxizeiro, uma vez que ambos os sinalizadores apresentaram um papel promotor sobre essa 
transição de comportamento fotossintético. Assim sendo, primeiramente buscou-se analisar se haveria uma alteração no conteúdo endógeno de ABA nas plantas de abacaxizeiro submetidas aos tratamentos de suplementação ou remoção de NO.

Como mostra a Tabela 12, o conteúdo endógeno de ABA detectado nas plantas tratadas com 50 nM de NO na ausência de estresse hídrico foi aproximadamente 3.3 vezes mais elevados que aqueles observados nas plantas controle. Por outro lado, verificou-se que as plantas expostas ao estresse hídrico e tratadas com $100 \mu \mathrm{M}$ de cPTIO apresentaram uma redução de cerca de $34 \%$ nos teores endógenos de ABA em relação às plantas não tratadas com esse seqüestrador de NO (Tabela 12).

Tabela 12: Conteúdo endógeno de ABA em plantas de abacaxizeiro tratadas durante 15 dias com 0 ou 500 nM de NO gasoso na ausência de estresse hídrico ou com 0 ou $100 \mu \mathrm{M}$ de CPTIO na presença de estresse hídrico. Valores médios ( \pm DP).

\begin{tabular}{lc}
\hline Tratamento & Teores de ABA (pmol. $\mathbf{g}^{-1}$ MS) \\
\hline Controle & $96.6( \pm 10.2) \mathrm{d}$ \\
NO gasoso $(50 \mathrm{nM})$ & $321.7( \pm 42.7) \mathrm{c}$ \\
Estresse hídrico & $2014.3( \pm 142.5) \mathrm{a}$ \\
Estresse hídrico + cPTIO $(100 \mu \mathrm{M})$ & $1329.4( \pm 59.6) \mathrm{b}$ \\
\hline Médias seguidas da mesma letra não diferem significativamente pelo teste de Tukey $(\mathrm{P}<0,05)$.
\end{tabular}

Com base nesses resultados, foram realizados experimentos adicionais a fim de avaliar se a sinalização do NO durante a indução do CAM em abacaxizeiro dependeria de alterações no conteúdo endógeno de ABA. Para tal, plantas mantidas na ausência de estresse hídrico foram submetidas a tratamentos com NO na presença de fluridona.

Os resultados revelaram que a aplicação desse inibidor da síntese de ABA não afetou significativamente o efeito promotor do NO sobre o acúmulo noturno de malato e as atividades da PEPC e MDH (Figura 44). Da mesma forma, não foram observadas diferenças significativas no conteúdo hídrico foliar das plantas tratadas com esses compostos (Tabela 13). 


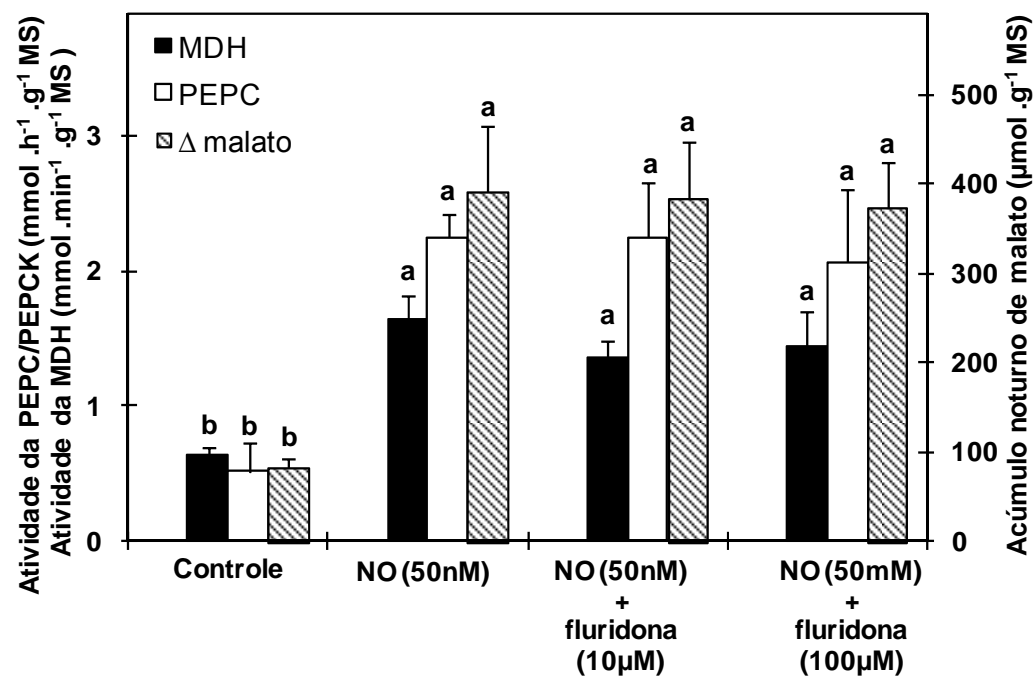

Figura 44. Efeitos do tratamento com NO e fluridona sobre a indução do CAM em abacaxizeiro. As plantas foram tratadas simultaneamente com NO (0 ou $50 \mathrm{nM}$ ) e com 0, 10 ou $100 \mu \mathrm{M}$ de fluridona (inibidor da síntese de $A B A$ ) durante 15 dias na ausência de estresse hídrico. As aplicações de NO foram realizadas diariamente. A atividade da PEPCK não foi quantificada nesses experimentos. Os valores mostrados representam a média \pm DP de experimentos realizados em triplicata. Barras com a mesma letra não diferem significativamente pelo teste de Tukey $(P<0,05)$.

Tabela 13: Teor relativo de água nas folhas de abacaxizeiro após 15 dias de tratamento com NO e fluridona na ausência de estresse hídrico. Valores médios ( \pm DP), $n=10$.

\begin{tabular}{lc}
\hline Tratamento & Teor relativo de água $(\%)$ \\
\hline Controle & $96.3( \pm 2.2) \mathrm{a}$ \\
$\mathrm{NO}(50 \mathrm{nM})$ & $97.3( \pm 0.4) \mathrm{a}$ \\
$\mathrm{NO}(50 \mathrm{nM})+$ fluridona $(10 \mu \mathrm{M})$ & $96.2( \pm 1.1) \mathrm{a}$ \\
$\mathrm{NO}(50 \mathrm{nM})+$ fluridona $(100 \mu \mathrm{M})$ & $95.4( \pm 1.8) \mathrm{a}$ \\
\hline Médias seguidas da mesma letra não diferem significativamente pelo teste de Tukey $(\mathrm{P}<0,05)$.
\end{tabular}

De modo complementar, a participação do NO como um possível mediador do sinal do ABA durante a indução do CAM também foi investigada. Nesse sentido, procedeu-se, inicialmente, à comparação dos teores de produção de $\mathrm{NO}$ em plantas de abacaxizeiro tratadas com 0,10 ou $100 \mu \mathrm{M}$ de ABA.

Como mostra a Figura 45, as análises dos teores de emissão de NO, por quimiluminescência, revelaram que as plantas submetidas ao tratamento com $100 \mu \mathrm{M}$ de $\mathrm{ABA}$, apresentaram um aumento de cerca de $150 \%$ na produção de NO. Além disso, as plantas tratadas com $10 \mu \mathrm{M}$ de $\mathrm{ABA}$ também apresentam uma tendência de aumento 
na produção de NO em relação ao controle, muito embora essa diferença não tenha sido significativamente diferente pelo teste de Tukey $(P<0,05)$.

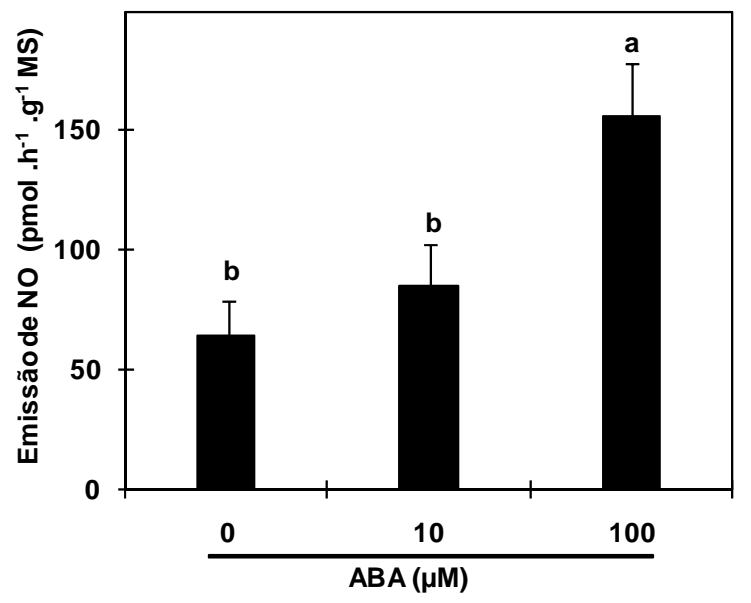

Figura 45. Teores de emissão de óxido nítrico em plantas abacaxizeiro tratadas com ácido abscísico. As plantas foram mantidas nos tratamento com 0, 10 ou $100 \mu \mathrm{M}$ de ABA por 2 dias e, em seguida, submetidas à quantificação da emissão de NO por quimiluminescência. Os valores mostrados representam a média \pm DP de experimentos realizados em duplicata. Barras com a mesma letra não diferem significativamente pelo teste de Tukey $(P<0,05)$.

Em consonância com esses resultados, as análises da produção in situ de NO por microscopia de fluorescência também evidenciaram a existência de maiores níveis de detecção desse radical livre nos tecidos foliares das plantas tratadas com 10 ou 100 $\mu \mathrm{M}$ de $\mathrm{ABA}$ do que naqueles oriundos das plantas mantidas na condição controle (Figuras 46 e 47).

Assim como observado nos tratamentos de estresse hídrico, o aumento na produção de NO desencadeado pelo ABA ocorreu principalmente nas células do parênquima clorofilado e células epidérmicas (Figuras 46 e 47). De forma condizente, a aplicação do seqüestrador de óxido nítrico cPTIO eliminou grande parte da marcação do NO observada nas células do parênquima clorofilado (Figura 47, foto F). 


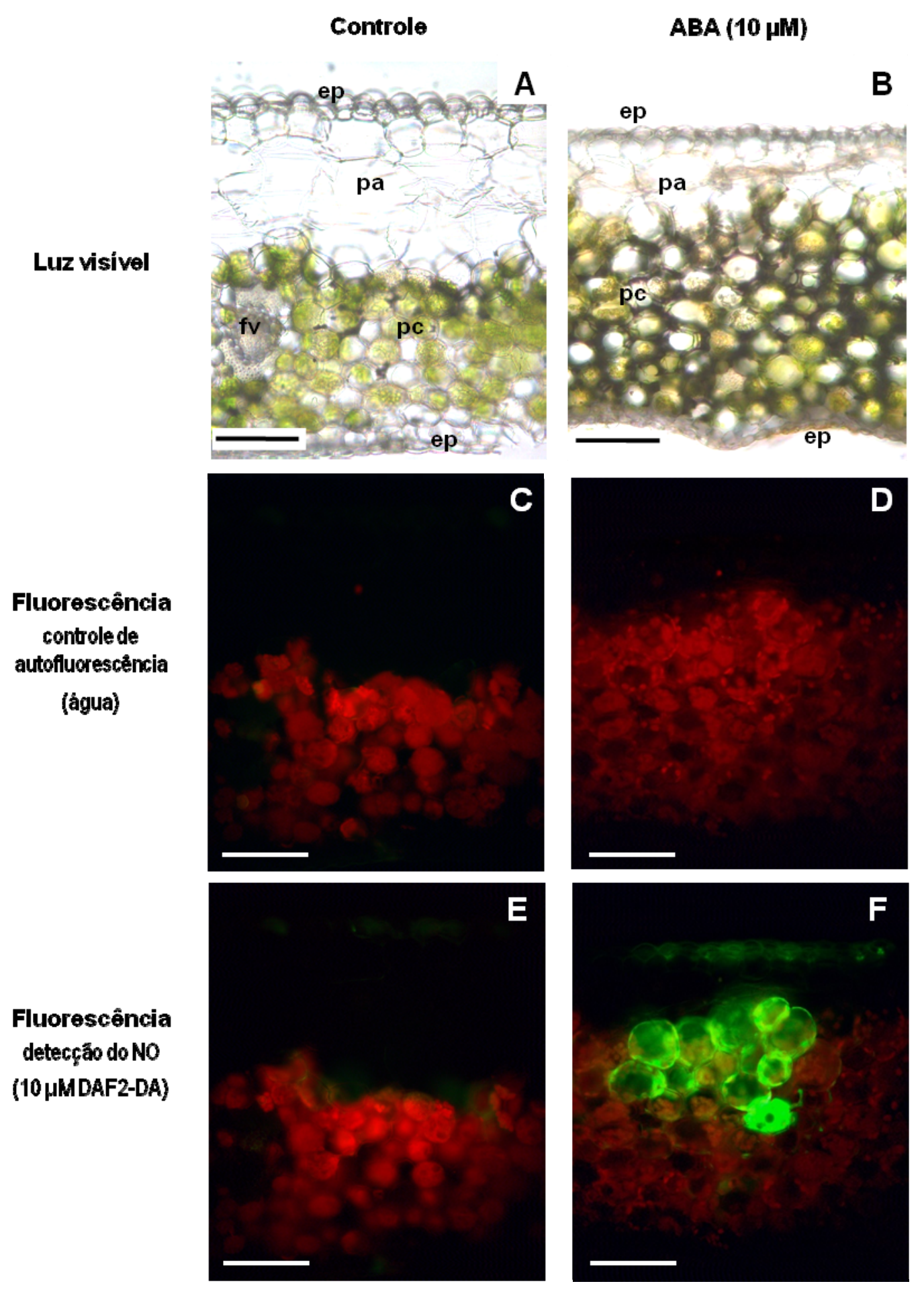

Figura 46. Análise da produção in situ de NO, por microscopia de fluorescência, em folhas de A. comosus após 2 dias de incubação com 0 ou $10 \mu \mathrm{M}$ de ABA. Primeiramente, os cortes foram analisados sob luz visível (A e B) ou em fluorescência (450 nm de excitação e $515 \mathrm{~nm}$ de emissão) apenas na presença de água (C e D). A seguir, esses cortes foram incubados com $10 \mu \mathrm{M}$ de DAF-2DA durante 30 minutos e novamente analisados em fluorescência (E e F). As emissões de fluorescência esverdeada e vermelha indicam, respectivamente, a produção de NO e a autofluorescência dos cloroplastos. As imagens são representativas de experimentos realizados em triplicata. Legenda: ep, epiderme; pa, parênquima aqüífero; pc, parênquima clorofilado; fv, feixe vascular. Barra $=100 \mu \mathrm{m}$. 


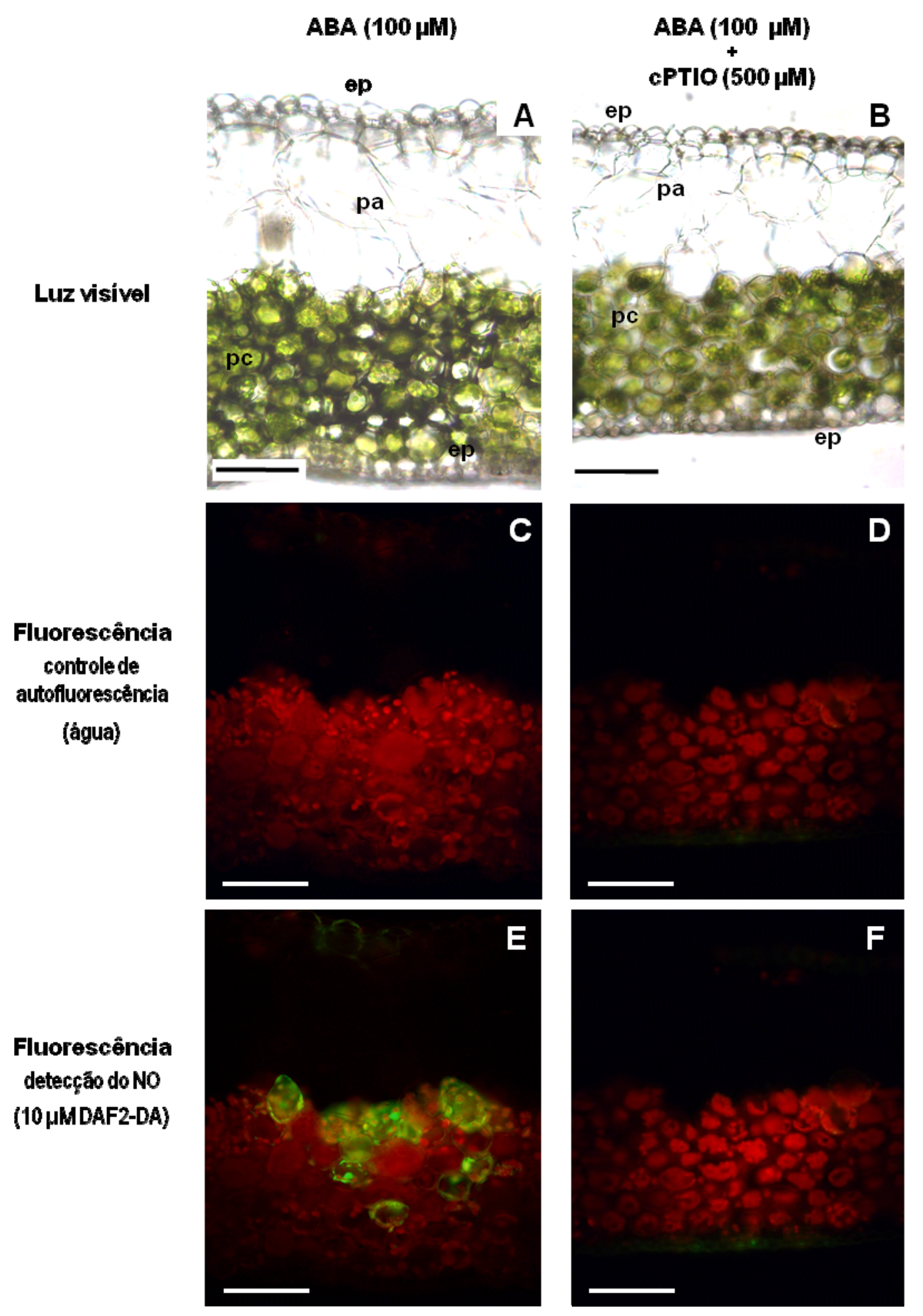

Figura 47. Análise da produção in situ de NO, por microscopia de fluorescência, em folhas de A. comosus após 2 dias de incubação com $100 \mu \mathrm{M}$ de ABA na presença ou ausência de CPTIO. Primeiramente, os cortes foram analisados sob luz visível (A e B) ou em fluorescência (450 nm de excitação e $515 \mathrm{~nm}$ de emissão) apenas na presença de água (C e D). A seguir, esses cortes foram incubados com $10 \mu \mathrm{M}$ de DAF-2DA durante 30 minutos e novamente analisados em fluorescência (E e F). Nos tratamentos com CPTIO $(500 \mu \mathrm{M})$, foi realizada uma pré-incubação dos cortes com esse seqüestrador de NO durante cerca de 30 minutos antes da marcação com o DAF-2DA. As imagens são representativas de experimentos realizados em triplicata. Legenda: ep, epiderme; pa, parênquima aqüífero; pc, parênquima clorofilado; fv, feixe vascular. Barra $=100 \mu \mathrm{m}$. 
Também foram realizados tratamentos que combinaram a aplicação de ABA com a presença de $\mathrm{CPTIO}$, com o intuito de verificar se a indução do CAM pelo ABA seria dependente da presença de NO nos tecidos foliares de abacaxizeiro.

Esses tratamentos revelaram que a aplicação de $500 \mu \mathrm{M}$ de cPTIO inibiu quase que completamente o efeito estimulatório do ABA sobre a indução do CAM em abacaxizeiro, uma vez que observou-se uma redução pronunciada no $\Delta$ malato dessas plantas, bem como o estabelecimento de valores de atividade da PEPC e MDH similares aos das plantas controle (Figura 48). Por outro lado, o tratamento com $100 \mu \mathrm{M}$ de cPTIO apenas desencadeou reduções consideráveis no $\Delta$ malato das plantas tratadas com ABA, não afetando significativamente suas atividades enzimáticas (Figura 48).

Também foi observado que as duas concentração de cPTIO (100 ou $500 \mu \mathrm{M}$ ) utilizadas reduziram os teores de água das plantas tratadas com ABA (100 $\mu \mathrm{M})$ para valores similares aos detectados nas plantas controle (Tabela 14).

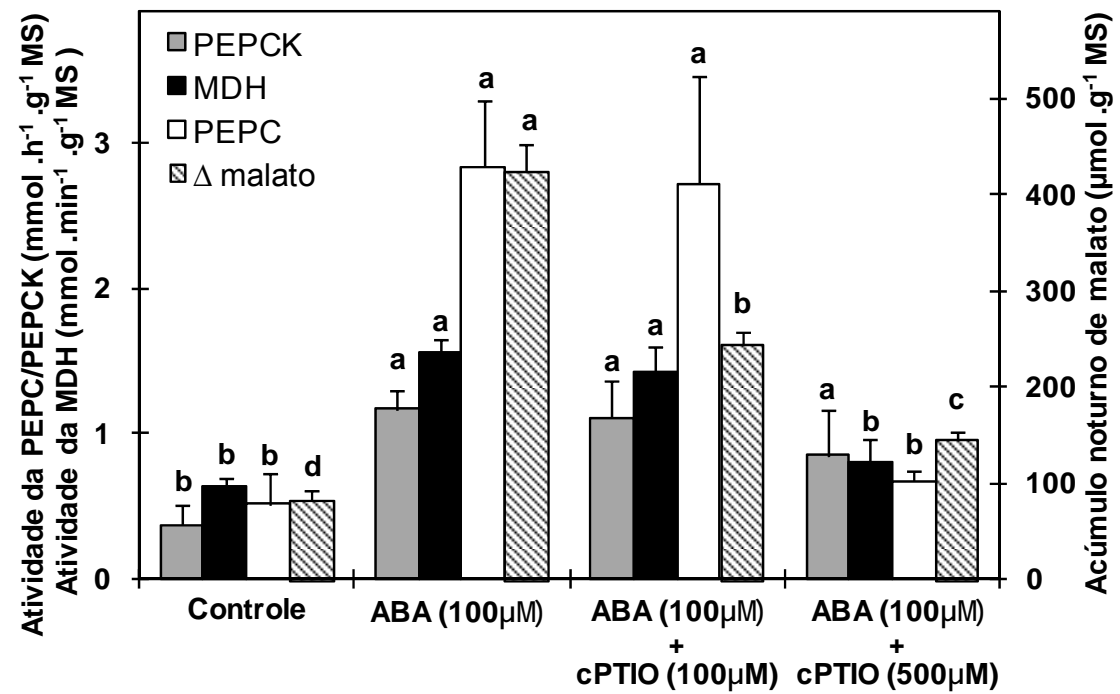

Figura 48. Efeitos do tratamento com ABA e cPTIO sobre a indução do CAM em abacaxizeiro. As plantas foram tratadas simultaneamente com ABA (0 ou $100 \mu \mathrm{M}$ ) e com 0,100 ou $500 \mu \mathrm{M}$ de cPTIO (seqüestrador de NO) durante 15 dias. As aplicações de CPTIO foram realizadas diariamente. Os valores mostrados representam a média \pm DP de experimentos realizados em triplicata. Barras com a mesma letra não diferem significativamente pelo teste de Tukey $(P<0,05)$. 
Tabela 14: Teor relativo de água nas folhas de abacaxizeiro após 15 dias de tratamento com ABA e cPTIO na ausência de estresse hídrico. Valores médios ( $\pm \mathrm{DP}), n=10$.

\begin{tabular}{lc}
\hline Tratamento & Teor relativo de água $(\%)$ \\
\hline Controle & $95.2( \pm 1.2) \mathrm{b}$ \\
ABA $(100 \mu \mathrm{M})$ & $98.9( \pm 0.4) \mathrm{a}$ \\
ABA $(100 \mu \mathrm{M})+$ CPTIO $(100 \mu \mathrm{M})$ & $94.2( \pm 2.1) \mathrm{b}$ \\
ABA $(100 \mu \mathrm{M})+$ CPTIO $(500 \mu \mathrm{M})$ & $93.4( \pm 1.4) \mathrm{b}$ \\
\hline
\end{tabular}

\section{$\underline{\text { Interação entre o } \mathrm{NO} \text { e o } \mathrm{Ca}^{2+} \text { cit. durante a indução do CAM em abacaxizeiro }}$}

Por fim, também foi analisada uma possível participação do $\mathrm{Ca}^{2+}$ citossólico como um mediador do sinal do NO durante a indução do CAM. Observou-se que plantas de abacaxizeiro tratadas com NO na presença de EGTA, apresentaram níveis de $\Delta$ malato e de atividade da PEPC e da MDH inferiores aos detectados nas plantas expostas ao NO na ausência desse quelante de $\mathrm{Ca}^{2+}$ extracelular (Figura 49). De modo interessante, foi constatado que a aplicação de $10 \mathrm{mM}$ de EGTA inibiu completamente o efeito do NO sobre a expressão do CAM, uma vez que os teores de atividade enzimática e de $\Delta$ malato constatados nas plantas tratadas com essa concentração de quelante foram estatisticamente similares aos detectados nas plantas não tratadas com NO (Figura 49).

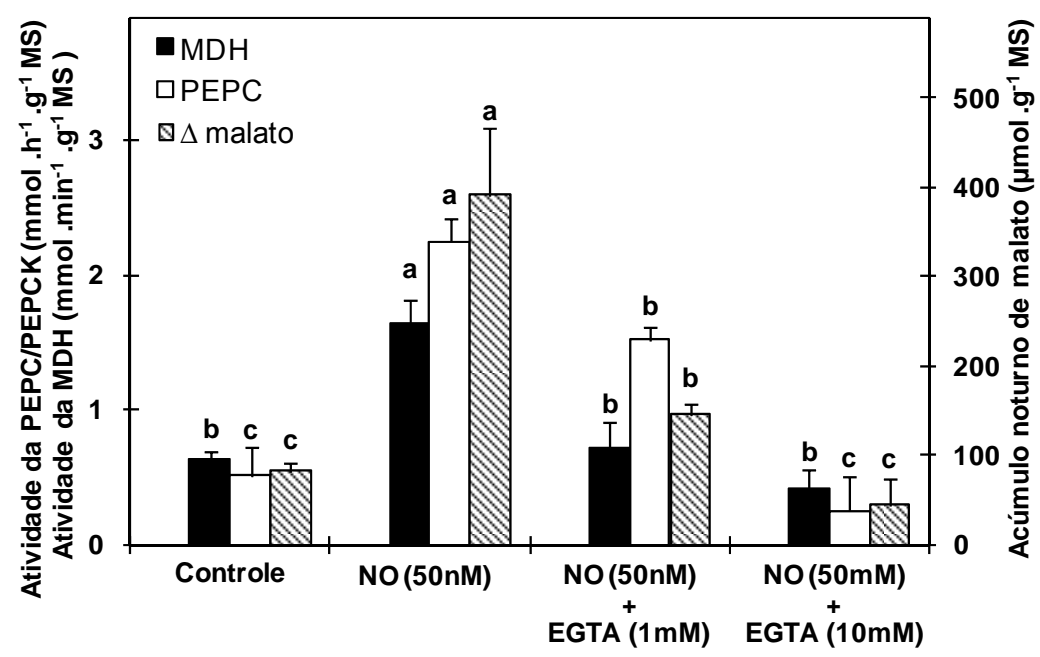

Figura 49. Efeitos do tratamento com NO e EGTA sobre a indução do CAM em abacaxizeiro. As plantas foram tratadas simultaneamente com NO (0 ou $50 \mathrm{nM}$ ) e com 0, 1 ou $10 \mathrm{mM}$ de EGTA (quelante de $\mathrm{Ca}^{2+}$ extracelular) durante 15 dias. As aplicações de NO foram realizadas diariamente. Os valores mostrados representam a média \pm DP de experimentos realizados em triplicata. Barras com a mesma letra não diferem significativamente pelo teste de Tukey $(P<0,05)$. 


\section{DIscussÃo}

Um dos fatores ambientais que apresenta maior influência sobre o nível de expressão do CAM em espécies $\mathrm{C}_{3}$-CAM facultativas é o estresse hídrico (CUSHMAN, 2001; CUSHMAN \& BORLAND, 2002; TAYBI et al., 2002). Esse estímulo desencadeia aumentos pronunciados na abundância e atividade de diversas enzimas envolvidas na síntese e degradação de carboidratos e ácidos orgânicos, bem como estimula a produção de proteínas regulatórias essenciais para o estabelecimento desse tipo de comportamento fotossintético (HOLTUM \& WINTER 1982; LI \& CHOLLET, 1994; BORLAND et al. 1998; CUSHMAN \& BORLAND, 2002). O efeito promotor do estresse hídrico sobre a indução do CAM tem sido demonstrando em um grande número de espécies CAM facultativas, incluindo Mesembryanthemum crystallinum (WINTER \& GADEMANN, 1991; TAYBI et al., 2002), Umbilicus rupestris (DANIEL et al. 1985), Portulacaria afra (GURALNICK \& TING, 1986), Sedum integrifolium (GRAVATT \& MARTIN, 1992), Pedilanthus tithymaloides (REDDY et al., 2003), Guzmania monostachia (MEDINA et al., 1977; LÜTTGE et al., 1986), e algumas espécies do gênero Kalanchöe (BRULFERT et al., 1988, 1993, 1996) ou Clusia (BORLAND et al. 1992, 1998; FRANCO et al., 1992; ZOTZ \& WINTER, 1993; LÜTTGE, 2006; VAASEN et al., 2006; WINTER et al., 2008).

No presente trabalho observou-se que a disponibilidade hídrica também exerce forte influência sobre o tipo de comportamento fotossintético apresentado por $A$. comosus. Constatou-se que as plantas de abacaxizeiro cultivadas in vitro na ausência de estresse hídrico apresentaram teores reduzidos tanto de acúmulo noturno de malato ( $\triangle$ malato) quanto de abundância de transcritos e atividade das enzimas PEPC, MDH e PEPCK (Figuras 2; 4, 5, 6 e 7). Tais resultados permitiram caracterizar a ocorrência de fotossíntese do tipo $\mathrm{C}_{3}$ nessas plantas, corroborando, dessa forma, os resultados obtidos por NIEVOLA et al. (2005). Por outro lado, quando as plantas de abacaxizeiro foram submetidas ao estresse hídrico, observou-se uma clara transição da fotossíntese 
$\mathrm{C}_{3}$ para $\mathrm{CAM}$, indicada pelo aumento progressivo no acúmulo noturno de ácido málico e nos teores de transcritos e atividades da PEPC, MDH e PEPCK (Figuras 2; 4, 5, 6 e 7).

As análises dos níveis de expressão do RNAm dessas enzimas revelaram que o início da indução do CAM em $A$. comosus esteve compreendido entre o $5^{\circ}$ e $6^{\circ}$ dia após a transferência das plantas para a condição de estresse hídrico. Além disso, os dados de $\Delta$ malato e de atividade enzimática indicaram que a transição da fotossíntese $C_{3}$ para CAM em abacaxizeiro ocorreu de modo gradual, alcançando seus valores máximos a partir do $15^{\circ}$ dia de incubação das plantas na presença de estresse hídrico. De forma semelhante REDDY et al (2003), trabalhando com a espécie $\mathrm{C}_{3}$-CAM facultativa Pedilanthus tithymaloides, demonstraram um aumento progressivo nas atividades das enzimas PEPC, MDH e PEPCK entre o $10^{\circ}$ e $20^{\circ}$ dia de exposição ao estresse hídrico, indicando que também nessa espécie a mudança da fotossíntese $\mathrm{C}_{3}$ para CAM ocorre de maneira gradual (REDDY et al., 2003). Contudo, vale ressaltar que o tempo de exposição ao estresse hídrico necessário para desencadear a mudança no tipo de comportamento fotossintético varia consideravelmente entre as espécies $\mathrm{C}_{3}$-CAM facultativas (CUSHMAN \& BORLAND, 2002). Na bromélia Guzmania monostachia, por exemplo, a mudança da fotossíntese $\mathrm{C}_{3}$ para CAM ocorre de forma bastante rápida, completando-se após uma semana da transferência das plantas para a condição de estresse hídrico (MEDINA et al., 1977). Já em Clusia minor (ZOTZ \& WINTER, 1993), Mesembryanthemum crystallinum (DAI et al., 1994; CUSHMAN \& BORLAND, 2002) e Sedum telephium (CONTI \& SMIRNOFF, 1994) a indução do CAM parece ocorrer de modo ainda mais rápido, uma vez que aumentos substanciais no acúmulo de malato ou nos teores de atividades das enzimas do comportamento CAM podem ser observados entre 12 e 24 horas após a exposição das plantas à condição de estresse hídrico.

De modo interessante, os dados obtidos também demonstraram que a indução do CAM em A. comosus ocorre de maneira reversível, já que as plantas submetidas ao tratamento de estresse hídrico e, posteriormente retornadas para a condição controle apresentaram uma tendência de diminuição no $\Delta$ malato e nos teores de transcritos e 
atividade da PEPC, MDH e PEPCK (Figuras 9 a 12). Observou-se que a partir do $20^{\circ}$ dia de tratamento, as plantas submetidas à reversão do CAM apresentaram valores de $\Delta$ malato e atividades das enzimas do CAM similares aos detectados na condição controle, indicando uma reversão completa da fotossíntese CAM para a $\mathrm{C}_{3}$ durante esse período. A reversibilidade entre o comportamento fotossintético $\mathrm{C}_{3}$ e CAM pode ser considerado um fenômeno bastante raro, uma vez que a maioria das espécies CAM facultativas sofre uma mudança irreversível do comportamento $\mathrm{C}_{3}$ para o CAM ao longo da ontogenia ou quando expostas à condições indutoras (CUSHMAN \& BORLAND, 2002; TAYBI et al., 2002). Relatos da ocorrência de reversão da fotossíntese CAM para a $C_{3}$ restringem-se à bromélia Guzmania monostachia (MEDINA et al., 1977; LÜTTGE et al., 1986), Pedilanthus tithymaloides (REDDY et al., 2003), Sedum telephium (CONTI \& SMIRNOFF, 1994) e algumas espécies do gênero Clusia (BORLAND et al., 1992; ZOTZ \& WINTER, 1993; LÜTTGE, 2006).

De modo geral, os processos de indução e de reversão do CAM em abacaxizeiro apresentaram forte correlação com os teores relativos de água detectados nos tecidos foliares dessa bromélia. Constatou-se, por exemplo, que o início da indução do comportamento CAM (Figuras 4 a $7,5^{\circ}-6^{\circ}$ dia) coincidiu justamente com o período de forte redução nos teores de água das folhas de abacaxizeiro (Figura $8,4^{\circ}-6^{\circ}$ dia). Em contrapartida, a reversão completa do CAM, (Figuras 9 a 12, $20^{\circ}$ dia), foi precedida pelo re-estabelecimento dos teores originais de conteúdo hídrico nos tecidos foliares de abacaxizeiro (Figura 13, $15^{\circ}$ dia). De forma análoga, trabalhos realizados em outras espécies CAM facultativas também têm demonstrado que alterações no turgor foliar precedem ou ocorrem concomitantemente ao processo de transição da fotossíntese $\mathrm{C}_{3}$ para CAM (WINTER \& GADEMANN, 1991; CONTI \& SMIRNOFF, 1994; SCHMITT \& PIEPENBROCK, 1992; HERPPICH \& HERPPICH, 1997) ou do comportamento CAM para C $_{3}$ (CONTI \& SMIRNOFF, 1994; CUSHMAN \& BORLAND, 1992).

A capacidade de alternar de maneira reversível entre o comportamento fotossintético $\mathrm{C}_{3}$ ou CAM torna o abacaxizeiro cultivado in vitro um modelo adequado 
para estudos dos sinais envolvidos tanto na mudança da fotossíntese $C_{3}$ para CAM quanto na reversão da fotossíntese $\mathrm{CAM}$ para a $\mathrm{C}_{3}$. Desse modo, o presente trabalho buscou caracterizar a influência de quatro classes hormonais, bem como do cálcio citossólico e do óxido nítrico sobre os processos de indução e de reversão do CAM nessa bromélia.

Visto que a indução da fotossíntese CAM é desencadeada por estresses ambientais que também provocam o aumento no conteúdo endógeno de $A B A$, essa foi a primeira classe hormonal a ser estudada no que tange à sinalização da indução desse tipo de comportamento fotossintético (TING, 1981; TAYBI et al., 2002). Tais estudos revelaram um papel promotor do ABA sobre a indução do CAM em diversas espécies $\mathrm{C}_{3}$-CAM facultativas como, por exemplo, Portulacaria afra (TING, 1981), Kalanchöe blossfeldiana (TAYBI et al., 1995) e M. crystallinum (CHU et al., 1990; THOMAS et al., 1992; BARKLA et al., 1999; TAYBI \& CUSHMAN, 1999, 2002).

Os resultados obtidos no presente trabalho indicaram que aplicação de ABA também exerce forte influência sobre o tipo de comportamento fotossintético apresentado por $A$. comosus, resultando na indução do CAM mesmo em plantas mantidas na ausência de estresse hídrico (Figura 14A). Assim como constatado em $M$. crystallinum (CHU et al., 1990; DAl et al., 1994) e K. blossfeldiana (TAYBI et al., 1995), o efeito promotor do ABA sobre a indução do CAM em A. comosus não foi dependente de reduções no teor relativo de água nas folhas dessa bromélia (Tabela 3).

As quantificações dos teores endógenos de ABA durante a indução do CAM em abacaxizeiro demonstraram que o início dessa mudança de comportamento fotossintético foi precedido por um aumento de cerca de 10 vezes no conteúdo endógeno desse fitormônio (Figura 15). Trabalhos realizados com outras espécies $\mathrm{C}_{3^{-}}$ CAM facultativas também evidenciaram aumentos consideráveis no conteúdo endógeno de $A B A$ durante a indução do CAM em resposta ao déficit hídrico, salinidade ou fotoperiodismo (THOMAS et al., 1992; THOMAS \& BOHNERT, 1993; TAYBI et al., 1995; TAYBI \& CUSHMAN, 2002). THOMAS et al. (1992), trabalhando com plantas de $M$. 
crystallinum expostas ao estresse salino, constataram que o aumento nos teores de transcritos da PEPC foi concomitante a uma elevação de 8 a 10 vezes no conteúdo foliar de ABA. Posteriormente, TAYBI et al. (1995), analisando o processo de indução do CAM em $K$. blossfeldiana em resposta ao estresse hídrico ou fotoperiodismo, observaram que, independente da natureza do sinal ambiental, havia um incremento acentuado no conteúdo endógeno de ABA horas antes do início do aumento nos teores de expressão do RNAm da PEPC. Mais recentemente, TAYBI \& CUSHMAN (2002) verificaram um aumento de aproximadamente 54 vezes no conteúdo endógeno de $A B A$ durante a indução do CAM em folhas destacadas de $M$. crystallinum submetidas à desidratação.

As análises hormonais realizadas em abacaxizeiro também revelaram que os valores máximos de indução do CAM (Figura 2) e de acúmulo de ABA (Figura 15) foram atingidos simultaneamente após a incubação das plantas por 15 dias na condição de estresse hídrico. De modo análogo, THOMAS et al., (1992) também observaram que o estabelecimento dos teores máximos de expressão do CAM em plantas de $M$. crystallinum expostas ao estresse salino coincidiu com o período em que os maiores teores de ABA foram detectados.

Indícios adicionais do envolvimento do ABA na regulação da expressão do CAM em abacaxizeiro foram obtidos por meio das análises do conteúdo endógeno desse fitormônio durante a reversão da fotossíntese CAM para $C_{3}$. Observou-se uma redução simultânea nos teores de ABA (Figura 16) e no grau de expressão do CAM (Figuras 9 a 12) durante os primeiros 20 dias após a transferência das plantas do tratamento de estresse hídrico para a condição controle. Como conseqüência, a transição completa do comportamento CAM para $\mathrm{C}_{3}$ em abacaxizeiro foi concomitante ao estabelecimento de teores de ABA similares entre as plantas da condição controle e aquelas submetidas ao tratamento de reversão do CAM. De forma semelhante, BASTIDE et al. (1993), constataram que poucos dias após a reidratação dos tecidos da planta CAM Xerosicyos danguyi houve uma redução simultânea nos teores de ABA e na atividade da PEPC. 
Assim sendo, os resultados obtidos no presente estudo demonstraram que os processos de indução e de reversão do CAM foram acompanhados de, respectivamente, aumentos e reduções no conteúdo de $A B A$ nos tecidos foliares de abacaxizeiro, sugerindo a atuação desse fitormônio como um mediador do efeito estimulatório do déficit hídrico sobre o grau de expressão do CAM nessa bromélia.

Contudo, experimentos de inibição da síntese de ABA demonstraram que a indução de $A$. comosus ao CAM em resposta ao estresse hídrico pode ocorrer mesmo na ausência de aumentos no conteúdo endógeno desse fitormônio (Figura 14B, Tabela 4). Dessa forma, os dados obtidos permitem concluir que o aumento no conteúdo endógeno de $A B A$ não representa uma etapa essencial durante a sinalização da indução do CAM nessa bromélia. Resultados similares foram obtidos por THOMAS et al., (1992) e TAYBI \& CUSHMAN (2002), ao trabalharem com a indução do CAM em plantas de M. crystallinum expostas ao estresse hídrico ou salino. THOMAS et al., (1992) constataram que, embora o tratamento de plantas dessa espécie com levostatina, um inibidor da síntese de isoprenóides e $A B A$, tenha resultado em uma inibição de $75 \%$ no acúmulo de ABA desencadeado pelo estresse salino, a redução desse hormônio não afetou a indução do comportamento CAM. Mais recentemente, TAYBI \& CUSHMAN (2002) observaram que a incubação de folhas isoladas de $M$. crystallinum com fluridona também não influenciou a indução da expressão do RNAm da PEPC em resposta ao estresse hídrico, apesar desse inibidor ter causado reduções dramáticas nos teores endógenos de ABA. Além disso, esses autores constataram que durante a indução de $M$. crystallinum ao CAM em resposta à salinidade, não houve aumento significativo nos teores de ABA.

Pautado nessas evidências, TAYBI \& CUSHMAN (2002) propuseram que, além da via de sinalização do CAM dependente de ABA, também haveria uma segunda via de indução da mudança de $\mathrm{C}_{3}$ para CAM em $M$. crystallinum, a qual seria independente da participação desse hormônio. Em concordância com essa hipótese, estudos têm demonstrado que a sinalização de respostas a vários tipos de estresses ambientais 
como o frio, o estresse osmótico e a salinidade também ocorre tanto pela via dependente quanto pela independente de ABA (GOSTI et al., 1995; SAVOURE et al., 1997; BELLAIRE et al., 2000; RIERA et al. 2005). Além disso, estudos realizados com mutantes deficientes ou insensíveis ao $A B A$ têm demonstrado que as vias de sinalização dependente e independente de ABA interagem e convergem na ativação de genes de resposta ao frio, estresse hídrico e salinidade (GOSTI et al., 1995; ISHITANI et al., 1997).

Dessa forma, os dados obtidos no presente trabalho também sugerem a existência de duas vias sinalização durante a indução do CAM em $A$. comosus: a via dependente de $A B A$ e a via independente de ABA. A existência de uma via de sinalização do CAM em $A$. comosus que seja dependente da participação do ácido abscísico é indicada pelo efeito promotor do ABA exógeno sobre a expressão do CAM nessa espécie e também pela forte correlação temporal entre as variações nos teores endógenos desse hormônio e os processos de indução e de reversão do CAM. Por outro lado, a ocorrência da indução do CAM mesmo quando o acúmulo de ABA foi totalmente inibido, sugere a existência de uma via de sinalização independente da participação desse hormônio.

Além do ABA, outra classe hormonal que exerce forte influência sobre a indução do CAM são as citocininas (SCHMITT \& PIEPENBROCK, 1992; THOMAS et al., 1992; DAl et al., 1994; PETERS et al., 1997). Estudos realizados em M. crystallinum têm demonstrado que essa classe hormonal apresenta um papel repressor sobre a transição da fotossíntese $\mathrm{C}_{3}$ para CAM desencadeada pelo estresse hídrico ou salino (PETERS et al., 1997; DAl et al., 1994; TAYBI et al., 2002).

De modo condizente, os dados obtidos no presente trabalho também sugerem a atuação das citocininas como reguladoras negativas da indução do CAM em $A$. comosus. Foi constatado que plantas de abacaxizeiro tratadas com diferentes tipos de citocininas (Z, ZR, iP ou iPR) apresentaram uma inibição considerável da indução do CAM em resposta ao estresse hídrico (Figura 17B), sendo essa inibição independente 
de alterações no conteúdo hídrico foliar (Tabela 5). Resultados equivalentes foram obtidos por SCHMITT \& PIEPENBROCK (1992) e DAl et al. (1994) quando plantas de M. crystallinum expostas ao estresse salino ou à desidratação foram pré-tratadas com a citocinina benziladenina (BA). SCHMITT \& PIEPENBROCK (1992) observaram que quando plantas dessa espécie eram submetidas ao tratamento de indução do CAM por estresse salino e pulverizadas diariamente com BA havia uma redução nos teores de transcritos e atividade da PEPC, bem como no acúmulo noturno de acidez titulável. Posteriormente, DAl et al.(1994) constataram que o aumento da PEPC em folhas de $M$. crystallinum submetidas à desidratação foi parcialmente inibido quanto essas folhas eram pré-tratadas com BA.

Os resultados das quantificações de citocininas também sugerem um papel inibitório para essa classe hormonal durante a indução do CAM em A. comosus, uma vez que o período de maior redução no conteúdo endógeno das quatro citocininas analisadas (Figura $18,5^{\circ}-8^{\circ} \mathrm{dia}$ ) coincidiu temporalmente com o início da indução do CAM em resposta ao estresse hídrico (Figuras 4 a $7,5^{\circ}-6^{\circ}$ dia). Entre as citocininas analisadas, observou-se uma redução mais acentuada nos teores de Z e ZR durante o período de indução do CAM e, de modo interessante, ao longo dos tratamentos de suplementação, essas mesmas citocininas foram as mais efetivas na prevenção da indução CAM por estresse hídrico (Figura 17B). Outra correlação observada entre as citocininas e a indução do CAM em abacaxizeiro foi que o estabelecimento dos valores máximos de expressão desse comportamento fotossintético, constatado a partir do $15^{\circ}$ dia de exposição ao estresse hídrico (Figura 2), coincidiu com a presença dos menores teores endógenos das quatro citocininas quantificadas (Figura 18).

Outros trabalhos também têm demonstrado reduções consideráveis no conteúdo de citocininas presentes em tecidos foliares e exsudados xilemáticos de plantas expostas ao estresse hídrico ou salino (POSPISILOVA et al., 2000; ZHU et al., 2004; HARE et al., 1997). Por exemplo, KUIPER et al. (1990) observaram uma diminuição pronunciada no conteúdo de Z, ZR, iP e iPR em tecidos foliares e radiculares de plantas 
de cevada expostas ao estresse salino. Posteriormente, BANO et al. (1994) constataram uma redução substancial no conteúdo endógeno dessas mesmas citocininas em plantas de arroz submetidas à uma redução progressiva na disponibilidade hídrica do solo. Mais recentemente, HAVLOVA et al. (2008), analisaram os teores endógenos de 27 tipos de citocininas em plantas de tabaco submetidas ao estresse hídrico e constataram uma redução acentuada no conteúdo de todas as citocininas ativas. A explicação para a redução no conteúdo de citocininas em plantas expostas ao estresse hídrico ou salino parece ser tanto uma redução na biossíntese quanto um aumento na degradação desses compostos (POSPISILOVA et al., 2000; HAVLOVA et al., 2008).

Em contrapartida, poucos trabalhos analisaram a interação entre conteúdo endógeno de citocininas e a indução do CAM (THOMAS et al., 1992; PETERS et al., 1997). Em um desses estudos, THOMAS et al. (1992) observaram que o acúmulo de transcritos da PEPC em plantas de $M$. crystallinum induzidas ao CAM em resposta ao estresse salino não foi acompanhado de alterações consideráveis nos teores endógenos de citocininas do tipo zeatina. Posteriormente, PETERS et al. (1997) quantificaram os teores endógenos de 14 espécies citocinínicas em plantas de $M$. crystallinum na condição $\mathrm{C}_{3}$ ou induzidas ao CAM por déficit hídrico. Esses autores constataram que o conteúdo endógeno de citocininas detectado nas plantas induzidas ao CAM foi consideravelmente inferior àqueles observados nas plantas mantidas na condição $\mathrm{C}_{3}$ (PETERS et al., 1997). Além disso, a redução no conteúdo dessa classe hormonal ocorreu de modo proporcional ao aumento na quantidade de transcritos da PEPC, permitindo a esses autores propor um efeito repressor das citocininas endógenas sobre a expressão do CAM em M. crystallinum (PETERS et al., 1997).

Adicionalmente, os dados obtidos no presente trabalho demonstraram que a reversão da fotossíntese CAM para $\mathrm{C}_{3}$ em abacaxizeiro foi acompanhada de um aumento nos teores das quatro citocininas analisadas (Figura 20). Verificou-se que a reversão completa do CAM, observada a partir do $20^{\circ}$ dia de transferência das plantas do estresse hídrico para a condição controle (Figuras 9 a 12), foi concomitante ao re- 
estabelecimento dos teores iniciais de iP e iPR e uma elevação bastante significativa nos teores de Z e ZR (Figura 20). Ao contrário dessas observações, PETERS et al. (1997) constataram que quando folhas isoladas de $M$. crystallinum foram submetidas ao tratamento de reidratação houve uma redução pronunciada nos teores de transcritos da PEPC, contudo, os teores de citocininas nessas folhas permaneceram praticamente inalterados. Até o presente momento, não se tem conhecimento de outros trabalhos que tenham analisado os teores endógenos de citocininas em plantas $\mathrm{C}_{3}$-CAM facultativas submetidas ao aumento na disponibilidade hídrica (TAYBI et al., 2002). Porém, cabe ressaltar que estudos realizados em diversas espécies $C_{3}$ têm demonstrado um rápido aumento nos teores desse hormônio quando plantas expostas ao estresse hídrico foram retornadas para condições adequadas de suprimento de água (NAQVI, 1995; HAVLOVA et al. , 2008).

Os dados obtidos no presente estudo demonstraram que as variações nos teores endógenos de citocininas e ABA apresentaram tendências opostas durante as mudanças de comportamentos fotossintético em $A$. comosus. Verificou-se que a indução do CAM por estresse hídrico foi acompanhada de aumentos nos teores de ABA e reduções nos teores de citocininas, enquanto que a reversão do CAM foi concomitante a reduções e aumentos nos teores de ABA e citocininas, respectivamente. Tais resultados sugerem a ocorrência de um antagonismo entre essas duas classes hormonais durante as mudanças de comportamento fotossintético em abacaxizeiro. De forma condizente, diversos relatos na literatura indicam a existência de uma relação antagônica entre as citocininas e o ABA durante a sinalização de uma variedade de respostas fisiológicas como, por exemplo, no fechamento estomático, na senescência foliar e na dormência de sementes e gemas (POSPISILOVA et al., 2000).

Ao contrário do observado para as citocininas e para o $A B A$, muito pouco se conhece a respeito da atuação de outras classes hormonais na sinalização da expressão do CAM (TAYBI et al., 2002). Com relação às auxinas, por exemplo, sabe-se apenas que a aplicação do ácido 2,4-diclorofenoxiacético (2,4-D), uma auxina sintética, 
não apresentou efeito sobre a modulação do tipo de comportamento fotossintético apresentados por M. crystallinum (DAl et al., 1994). Conseqüentemente, a influência dessa classe hormonal sobre a expressão do CAM ainda não foi estabelecida para o restante das espécies $\mathrm{C}_{3}$-CAM facultativas, bem como faltam pesquisas que correlacionem os teores endógenos dessa classe hormonal e os processos de indução e de reversão do CAM nessas espécies (TAYBI et al., 2002).

No presente trabalho, foi observado que o tratamento de estresse hídrico resultou em variações pouco proeminentes no conteúdo de ácido indolilacético (AIA) em plantas de abacaxizeiro (Figura 23), demonstrando que o processo de indução do CAM nessa bromélia não foi acompanhado de grandes variações nos teores endógenos dessa auxina. Apenas foi observado que a partir do $7^{\circ}$ dia de tratamento, as plantas submetidas à indução do CAM apresentaram teores de AIA estatisticamente superiores aos detectados nas plantas controle. De forma análoga, também não foram constatadas alterações proeminentes no conteúdo de AIA das plantas de $A$. comosus submetidas ao tratamento de reversão do CAM (Figura 24).

Estudos que tenham analisado a influência da disponibilidade hídrica sobre os teores endógenos de auxinas têm se restringido principalmente a espécies com comportamento fotossintético do tipo $\mathrm{C}_{3}$ (VESELOV et al., 2002; GOMES et al. 2003; HAVLOVA et al., 2008). Parte desses trabalhos tem demonstrado que os teores endógenos de AIA nos tecidos vegetais permaneceram praticamente inalterados mesmo após períodos prolongados de estresse hídrico ou, ainda, durante o processo de reidratação (LOPEZ-CARBONELL et al., 1994; MAHOUACHI et al., 2007). Contudo, também existem relatos de reduções (GOMES et al. 2003) e aumentos (LOPEZCARBONELL et al., 1996;RIBAUT \& PILET, 1994; HAVLOVA et al., 2008) nos teores de auxinas durante a exposição das plantas ao estresse hídrico, dificultando o estabelecimento de padrões de comportamento.

Em consonância com os resultados obtidos nas análises hormonais, verificou-se que os tratamentos com AIA ou com o ácido n-1-naftilftalâmico (NPA), um inibidor do 
transporte polar de auxinas, não influenciaram o tipo de comportamento fotossintético apresentado por A. comosus (Figura 22). Portanto, o conjunto de dados obtidos no presente trabalho não indica o envolvimento das auxinas na modulação do tipo de comportamento fotossintético apresentado por $A$. comosus, corroborando observações anteriores realizadas em M. crystallinum (DAl et al., 1994).

Outro hormônio vegetal muito pouco estudado quanto à sua participação no processo de indução da fotossíntese CAM é o etileno (HURST et al., 2004, TAYBI et al., 1999). O único estudo que analisou o envolvimento desse hormônio na regulação do CAM evidenciou que o tratamento de plantas de M. crystallinum com 200 ppb (partes por bilhão) de etileno durante um período de 24 horas não resultou em aumentos significativos nos teores de transcritos da PEPC e no acúmulo noturno de ácidos orgânicos (HURST et al., 2004).

No presente trabalho, observou-se que plantas de abacaxizeiro tratadas com etileno ou com o inibidor de seus receptores (1-MCP) não apresentaram alterações consideráveis no acúmulo noturno de malato ou nas atividades de enzimas-chaves do CAM (Figura 25). Além disso, foi constatado que o processo de indução de $A$. comosus ao CAM em resposta ao estresse hídrico não foi acompanhado de grandes variações nos teores de emissão de etileno (Figura 26). As plantas submetidas à reversão do CAM, por sua vez, apresentaram teores de emissão desse hormônio superiores àqueles detectados nas plantas controle durante todo o período analisado (Figura 27).

Diversos trabalhos têm quantificado a produção de etileno por tecidos vegetais submetidos a condições de baixa disponibilidade hídrica (APELBAUM \& YANG, 1981; MORGAN et al., 1990; MORGAN \& DREW, 1997). Embora estudos pioneiros tenham demonstrado a ocorrência de teores elevados de emissão de etileno em folhas isoladas de plantas expostas a condições de estresse hídrico (ELBELTAG \& HALL, 1974; BENYEHOS \& ALONI, 1974; APELBAUM \& YANG, 1981; HOFFMAN et al., 1983; RIOV \& HAUSMAN, 1988), trabalhos mais recentes indicam que o estresse hídrico parece apresentar pouca influência sobre a produção desse hormônio em plantas intactas de 
diversas espécies (EKLUND et al. 1992; MORGAN \& DREW, 1997; NARAYANA et al., 1991; CHEN et al., 2002). Sugere-se, dessa forma, que os altos teores de emissão de etileno constatados nos trabalhos iniciais poderiam ser resultado da injuria mecânica causada durante o isolamento das folhas para realização das quantificações (EKLUND et al. 1992; NARAYANA et al., 1991; CHEN et al., 2002).

Em conjunto, os resultados dos tratamentos exógenos e das análises da emissão de etileno durante a indução ou a reversão do CAM não sugerem a participação dessa classe hormonal no controle da expressão da fotossíntese CAM em abacaxizeiro. Essa constatação corrobora, portanto, observações anteriores realizadas em M. crystallinum (HURST et al., 2004).

Além da participação de fitormônios, TAYBI \& CUSHMAN (1999) constataram que aumentos na concentração citossólica de $\mathrm{Ca}^{2+}$ representam uma etapa essencial durante a indução do CAM em M. crystallinum, envolvendo tanto o influxo desse íon do meio extracelular quanto sua liberação a partir de estoques intracelulares (TAYBI \& CUSHMAN, 1999).

De modo semelhante, os resultados obtidos no presente estudo indicaram que alterações na concentração de $\mathrm{Ca}^{2+}$ citossólico também parecem estar envolvidas na sinalização da indução do CAM em abacaxizeiro. Constatou-se que a aplicação de ionomicina, um ionóforo de $\mathrm{Ca}^{2+}$, resultou na indução do CAM em plantas de abacaxizeiro mantidas na ausência de estresse hídrico (Figura 28A), indicando uma correlação positiva entre o aumento na concentração citossólica desse íon e a indução da fotossíntese CAM nessa espécie. Por outro lado, também foi observado que o tratamento das plantas de abacaxizeiro com EGTA, um quelante de $\mathrm{Ca}^{2+}$ extracelular, resultou numa inibição parcial da indução do CAM por estresse hídrico (Figura 28B), sugerindo que durante a sinalização desse processo houve a necessidade de mobilização de $\mathrm{Ca}^{2+}$ extracelular.

Além de inibir a indução do CAM em resposta ao estresse hídrico, constatou-se que os tratamentos com EGTA também reduziram os teores de expressão do CAM nas 
plantas de abacaxizeiro tratadas com ABA. Dessa forma, o influxo de cálcio do apoplasto também parece representar uma etapa importante na transmissão do sinal do ABA durante a regulação da expressão do CAM em abacaxizeiro. Tais resultados se assemelham àqueles obtidos por TAYBI \& CUSHMAN (1999) em M. crystallinum, bem como corroboram um grande número de relatos que indicam a atuação do $\mathrm{Ca}^{2+}$ citossólico como um mensageiro secundário do $\mathrm{ABA}$ em resposta a estresses ambientais (REDDY, 2001; MEDVEDEV, 2005).

Também chama a atenção o fato de que o tratamento das plantas com $10 \mathrm{mM}$ de EGTA resultou em uma redução significativa no conteúdo de água no tecido foliar das plantas expostas ao estresse hídrico (Tabela 8) ou tratadas com ABA (Tabela 9). Uma possível explicação para essa perda excessiva de água poderia ser a ocorrência de controle menos eficiente do fechamento estomático, refletindo uma inibição, mesmo que parcial, do influxo de $\mathrm{Ca}^{2+}$ extracelular para o citoplasma das células-guardas dos estômatos (DODD et al., 2005).

Do mesmo modo que o $\mathrm{Ca}^{2+}$ citossólico, o óxido nítrico (NO) também tem sido indicado como um importante componente das cascatas de sinalização desencadeadas por fitormônios ou estresses ambientais (NEILL et al., 2003; ARASIMOWICZ \& FLORYSZAK-WIECZOREK, 2007). Tendo em vista que tanto o estresse hídrico quanto a aplicação de ABA estimulam a produção de NO nas plantas (LAMATTINA et al., 2003; GOULD et al., 2003, NEILL et al., 2008), e que esses mesmos tratamentos também levam à indução da fotossíntese CAM em várias espécies $\mathrm{C}_{3}$-CAM facultativas, incluindo o abacaxizeiro, foram realizados estudos com a finalidade de verificar se esse radical livre também estaria envolvido no processo de indução do CAM em A. comosus.

Foi constatado que a aplicação de doadores de óxido nítrico (SNP e NOC9) aumentou significativamente a expressão do CAM em plantas de abacaxizeiro mantidas na ausência de estresse hídrico (Figura 30A), indicando, de forma inédita, um possível papel sinalizador do NO na indução desse tipo de comportamento fotossintético. 
Cabe ressaltar que esses resultados iniciais foram obtidos por meio de doadores de NO e apesar do uso dessas substâncias ser muito comum em estudos sobre a regulação de eventos fisiológicos tanto em plantas quanto em animais (LAMATTINA et al., 2003; NAPOLI \& IGNARRO, 2003; NEILL et al., 2008), alguns autores têm levantado restrições quanto ao uso desses compostos (FLORYSZAK-WIECZOREK et al., 2006; GIBA et al., 1998; NAPOLI \& IGNARRO, 2003). Como exemplo disso, FLORYSZAKWIECZOREK et al. (2006) demonstraram que a liberação de NO por diversos tipos de doadores pode ser influenciada por fatores externos como temperatura, luminosidade, presença de agentes redutores ou, ainda, por ação do próprio tecido vegetal. Além disso, a maioria dos doadores de NO libera esse radical livre apenas por curtos intervalos de tempo e, conseqüentemente, não são adequados para experimentos de longa duração (LIBOUREL et al., 2006; FLORYSZAK-WIECZOREK et al., 2006). Também há ressalvas que salientam que, independente do tipo de doador de NO utilizado, sempre existirá a formação de outros produtos de degradação além do óxido nítrico, muitos dos quais são capazes de influenciar o metabolismo e desenvolvimento vegetal (LIBOUREL et al., 2006, KAISER \& PLANCHET, 2006). Sabe-se, por exemplo, que durante a decomposição do SNP em NO também são liberados íons de ferro (II) e de cianeto, ambos potencialmente tóxicos aos organismos vivos (FEELISCH, 1998; SHISHIDO \& DE OLIVEIRA, 2001; KOZLIK et al., 2004; OH \& MCCASLIN, 1995).

Assim sendo, o presente estudo também utilizou tratamentos com NO gasoso para fazer uma segunda checagem acerca do papel sinalizador do NO sobre a indução do CAM em abacaxizeiro. De forma interessante, esses tratamentos também resultaram na indução de $A$. comosus ao CAM na ausência de estresse hídrico (Figura 31A), confirmando, portanto, os resultados obtidos previamente por meio da aplicação de doadores de NO. Além disso, tal como observado nos tratamentos com SNP ou NO9, constatou-se que a indução do CAM em resposta à aplicação de NO gasoso não foi dependente de alterações no teor de água das folhas de abacaxizeiro, descartando a 
possibilidade de que a influência do óxido nítrico sobre a expressão do CAM tenha se dado em função de possíveis reduções no turgor celular.

Como evidência adicional do envolvimento do NO na sinalização da indução do CAM em abacaxizeiro, observou-se que os teores de emissão desse composto foram consideravelmente superiores nas plantas submetidas ao tratamento de estresse hídrico do que naquelas mantidas na condição controle. Além disso, a ocorrência de um pico de emissão de NO (Figura 32, $4^{\circ}$ dia) justamente um dia antes do início dos aumentos nos teores de transcritos de enzimas-chaves do comportamento CAM (Figura 4 a $7,5^{\circ}-6^{\circ}$ dia) demonstra a existência de uma correlação temporal entre a produção de NO e o processo de indução do CAM em abacaxizeiro. A ocorrência de elevações na síntese de NO em tecidos vegetais mantidos em condições de déficit hídrico já foi reportada para diversas espécies, tais como ervilha (LESHEM \& HARAMATY, 1996; KOLBERT et al., 2008), tabaco (GOULD et al., 2003), trigo (ZHAO et al., 2001), milho (HAO et al., 2008) e Vicia faba (GARCIA-MATA \& LAMATTINA, 2002). Segundo relatos recentes, esse aumento na produção de NO em plantas expostas ao estresse hídrico parece envolver tanto a enzima óxido nítrico sintase (NOS) quanto a nitrato redutase (NR) (ZHAO et al., 2001; HAO et al., 2008, NEILL et al., 2008; SANG et al. 2008a).

Em consonância com as quantificações da emissão de NO, as análises in situ da produção desse radical livre indicaram uma correlação não apenas temporal, mas também espacial entre a síntese de $\mathrm{NO}$ e a transição da fotossíntese $\mathrm{C}_{3}$ para a CAM em abacaxizeiro (Figura 33 a 42). Em termos temporais, observou-se que aumentos na produção de $\mathrm{NO}$ nos tecidos foliares dessa bromélia ocorreram a partir do $3^{\circ}$ dia de exposição das plantas ao estresse hídrico (Figura 33) antecedendo, portanto, o início da indução do CAM nessas plantas (Figuras 4 a 7, 50-6). Já em termos de distribuição espacial, foi interessante observar que os incrementos na produção de NO ocorreram principalmente nas células do parênquima clorofilado, sendo esse tecido um dos principais focos da reprogramação fisiológica, bioquímica e de expressão gênica necessária à mudança da fotossíntese $C_{3}$ para a CAM (CUSHMAN \& BOHNERT, 1997, 
1999). De fato, apesar da indução do CAM envolver alterações substanciais no metabolismo geral da planta, grande parte das mudanças necessárias para o estabelecimento desse tipo de comportamento fotossintético restringe-se às células do parênquima clorofilado, uma vez que nesse tecido ocorrem a expressão e atividade de proteínas regulatórias específicas do CAM (proteínas cinases e fosfatases), transportadores especiais, enzimas responsáveis pela fixação noturna do $\mathrm{CO}_{2}(\mathrm{PEPC})$, síntese de ácidos orgânicos (MDH, enolases) e descarboxilação diurna desses ácidos (PEPCK, ME) (BORLAND et al., 1998; CUSHMAN \& BOHNERT, 1997, 1999). Assim sendo, a existência de aumentos na produção de NO durante a indução do CAM justamente nas células do parênquima clorofilado parece dar suporte ao envolvimento do NO no controle da expressão desse tipo de comportamento fotossintético em $A$. comosus.

Ao contrário do observado durante a indução do CAM, as análises da emissão de NO durante a reversão do CAM em $A$. comosus revelaram uma tendência de diminuição nas taxas de produção desse radical livre (Figura 43). Assim sendo, de modo geral, os processos de indução e de reversão do CAM em abacaxizeiro foram acompanhados de, respectivamente, aumentos e reduções na produção de NO.

Entretanto, apesar dessa correlação positiva entre a produção de NO e a expressão do CAM em abacaxizeiro, constatou-se que a remoção desse radical livre dos tecidos das plantas expostas ao estresse hídrico, por meio de tratamentos com o seqüestrador de óxido nítrico $\mathrm{cPTIO}$, não afetou a indução do CAM em resposta a esse sinal ambiental (Figura 31).

Uma possível explicação para esses resultados poderia ser a de que as aplicações diárias de CPTIO não teriam sido suficientes para eliminar o NO produzido durante o período de incubação das plantas na presença de estresse hídrico, permitindo a indução do CAM pela via dependente desse radical livre. Por outro lado, uma hipótese alternativa poderia ser a existência de uma via de sinalização do CAM independente da participação do NO. Em consonância com essa segunda hipótese, NEILL et al. (2008) 
relataram que o fechamento estomático também pode ocorre por uma via independente de NO.

De acordo com a literatura atual, a atuação do NO na sinalização de respostas ao estresse hídrico poderia ocorrer de dois modos distintos, ambos fortemente relacionados ao acúmulo de ABA observado nessas condições (BELIGNI \& LAMATTINA, 2001; XING et al., 2004; BRIGHT et al., 2006; ZHAO et al., 2001; ZHANG et al., 2007). Um desses mecanismos consistiria na atuação do NO como mensageiro secundário do ABA (LAMATTINA et al., 2003; GARCIA-MATA \& LAMATTINA, 2002), sendo que, até o presente momento, o exemplo mais marcante de resposta fisiológica envolvendo esse modo de ação do NO consiste na regulação do fechamento estomático (NEILL et al., 2008). Em um trabalho pioneiro, GARCIA-MATA \& LAMATTINA (2001) demonstraram que a aplicação de NO, na forma do doador SNP, resultou no fechamento dos estômatos de modo rápido e reversível em várias espécies vegetais, mimetizando o efeito do ABA ou do estresse hídrico. Posteriormente, esses mesmos autores verificaram que a aplicação do cPTIO inibiu completamente o fechamento estomático em resposta ao $\mathrm{ABA}$, demonstrando que o modo de atuação NO durante essa resposta fisiológica consistiu na mediação do sinal hormonal (GARCIA-MATA \& LAMATTINA, 2002). Estudos adicionais têm corroborado esse modo de ação do NO ao demonstrarem a ocorrência de aumentos dramáticos na produção desse composto nas células-guardas dos estômatos minutos antes da ocorrência do fechamento estomático estimulado pela aplicação de ABA (NEILL et al., 2002; GARCIA-MATA \& LAMATTINA, 2002; DESIKAN et al., 2002). Também há relatos de que tratamentos com inibidores da síntese de NO previnem o fechamento dos estômatos induzido pela suplementação com ácido abscísico (NEILL et al., 2002; GUO et al., 2003; SHE et al., 2004; BRIGHT et al., 2006). Além disso, a indução do fechamento estomático pelo ABA é bastante reduzida nos mutantes que apresentam baixa produção de NO (GUO et al., 2003; BRIGHT et al., 2006). Ainda, ZHANG et al., 2007 relataram que o mutante vp5 de milho, deficiente na síntese de $A B A$, não apresentou aumentos na produção de NO quando exposto ao 
estresse hídrico, ao contrário do observado para o genótipo selvagem desta espécie. Em conjunto, esses relatos indicam que o NO atuaria como um componente posterior (downstream) ao ABA na cascata de sinalização dos eventos desencadeados pelo estresse hídrico.

Um segundo modo de atuação do NO durante a sinalização de respostas ao estresse hídrico encontra-se respaldada por relatos que apontam um efeito promotor desse radical livre sobre a síntese de ABA (ZHAO et al., 2001; XING et al., 2004). Temse demonstrado que a aplicação de NO é capaz de desencadear elevações no conteúdo endógeno de $A B A$ em tecidos radiculares de plantas de trigo e que, em contrapartida, tratamentos que provocam reduções na produção de NO também inibem o acúmulo desse hormônio em resposta ao estresse hídrico (ZHAO et al., 2001; XING et al., 2004). De forma complementar, XING et al. (2004) demonstraram que o tratamento de plântulas de trigo com SNP desencadeou uma redução na perda de água por transpiração e um acúmulo de ABA de maneira dose dependente. Esses autores também relataram que o tratamento das plântulas de trigo com fluridona inibiu parcialmente o efeito promotor do SNP sobre o acúmulo de ácido abscísico e sobre a redução na perda de água por transpiração (XING et al., 2004), indicando que o ABA seria um mediador na cascata de sinalização do NO durante a indução dessa resposta de tolerância à seca.

As análises realizadas no presente estudo também sugerem uma possível influência do NO sobre o conteúdo endógeno de ABA nos tecidos foliares de abacaxizeiro. Constatou-se que as plantas dessa espécie quando tratadas com NO apresentaram um aumento de cerca de 3 vezes nos teores de ABA mesmo na ausência de estresse hídrico (Tabela 12). De modo complementar, foi verificado que o tratamento com cPTIO reduziu significativamente os teores endógenos desse hormônio em plantas de abacaxizeiro expostas ao estresse hídrico (Tabela 12). Com base nesses resultados, uma hipótese que poderia ser aventada seria a de que o $A B A$ atuaria como um mediador do sinal do NO durante a indução do CAM em abacaxizeiro. Tal hipótese 
implicaria na eliminação do efeito promotor do NO sobre a indução do CAM caso a síntese de $A B A$ fosse bloqueada. Entretanto, foi observado que o tratamento das plantas de abacaxizeiro com um inibidor de síntese de ABA (fluridona) não afetou significativamente a indução de $A$. comosus ao CAM em resposta à aplicação de NO (Figura 44). Assim sendo, a participação do ABA como um mediador do sinal do NO parece pouco provável durante a sinalização da indução do CAM em abacaxizeiro.

Por outro lado, foram obtidas evidências que implicam na atuação do NO como um mensageiro secundário do ácido abscísico durante a indução do CAM em abacaxizeiro. Primeiramente, foi constatado que a aplicação de ABA provocou um aumento pronunciado na síntese de NO nessa bromélia, conforme indicado pelos maiores valores de emissão (Figura 45) e de detecção in situ desse composto (Figuras 46 e 47). Além disso, chama a atenção o fato do tratamento com $500 \mu \mathrm{M}$ de cPTIO ter prevenido quase que completamente a indução de $A$. comosus ao CAM em resposta à aplicação de ABA, sugerindo que o aumento na produção de NO representaria uma etapa essencial nessa via de transdução de sinal (Figura 48). Assim sendo, sugere-se que na cascata de sinalização da indução do CAM em abacaxizeiro o NO atuaria como um mediador do sinal do ABA, apresentando, portanto, similaridades com o que já foi relatado para a interação entre esses dois sinalizadores em outras respostas desencadeadas pelo estresse hídrico, tais como o fechamento estomático (GARCIAMATA \& LAMATTINA, 2002; NEILL et al., 2008), o aumento nas atividades das enzimas antioxidantes (ZHOU et al., 2005; ZHANG et al., 2007) e a ativação de algumas proteínas cinases (ZHANG et al., 2007).

Da mesma forma que observado em sistemas animais, trabalhos recentes têm demonstrado que o $\mathrm{Ca}^{2+}$ citossólico e o NO interagem durante a sinalização de diversas respostas fisiológicas nas plantas (GOULD et al. 2003 ; LAMATTINA et al. 2003; LAMOTTE et al. 2004, 2005; NEILL et al. 2008; BESSON-BARD et al., 2008; SANG et al., 2008b). Sabe-se, por exemplo, que o aumento na concentração citossólica de $\mathrm{Ca}^{2+}$ representa uma etapa essencial na via de transdução do sinal do NO que regula 
processos como o fechamento estomático (LAMATTINA et al., 2003; DESIKAN et al., 2004; NEILL et al., 2002), a formação de raízes adventíceas (LANTERI et al., 2006) e a indução de genes de defesa contra patógenos (DURNER et al., 1998; KLESSIG et al., 2000). De forma condizente, estudos têm demonstrado que a aplicação de doadores de NO promove um aumento transiente nas concentrações de $\mathrm{Ca}^{2+}$ citossólico tanto em células de tabaco em suspensão quanto nas células-guardas de Vicia faba (LAMATTINA et al., 2003; GOULD et al., 2003; LAMOTTE et al., 2004, 2005). Além disso, evidências sugerem que o aumento na concentração citossólica de $\mathrm{Ca}^{2}$ desencadeado pelo NO envolve tanto o influxo desse íon a partir do apoplasto quanto sua liberação de estoques intracelulares (LAMATTINA et al., 2003; GOULD et al., 2003; LAMOTTE et al., 2004, 2005; LANTERI et al., 2006, BESSON-BARD et al., 2008).

No presente trabalho, observou-se que o influxo de $\mathrm{Ca}^{2+}$ do meio extracelular também parece representar uma etapa importante para a transmissão do sinal do NO durante a indução do CAM em abacaxizeiro, uma vez que o tratamento das plantas como o quelante de cálcio EGTA resultou em uma redução do efeito promotor do NO sobre a expressão do CAM em $A$. comosus (Figura 49). Observou-se, ainda, que o efeito inibitório do EGTA sobre a indução do CAM pelo NO ocorreu de maneira dose dependente, sendo que a maior concentração utilizada desse quelante $(10 \mathrm{mM})$ bloqueou completamente o aumento no $\Delta$ malato e nas atividades enzimáticas. Esses resultados permitem sugerir que durante a indução do CAM pelo NO houve a necessidade do influxo de íons $\mathrm{Ca}^{2+}$ a partir do meio extracelular, ampliando, portanto, o entendimento acerca do modo de atuação desse radical livre durante o processo de indução do CAM em abacaxizeiro, além de fornecer evidências adicionais acerca das interações entre o $\mathrm{NO}$ e $\mathrm{Ca}^{2+}$ citossólico nas vias de sinalização em plantas.

Em suma, no presente estudo foram obtidas evidências consistentes acerca da participação do ABA, citocininas, NO e $\mathrm{Ca}^{2+}$ citossólico na sinalização da expressão do CAM em abacaxizeiro. De forma análoga ao relatado anteriormente para M. crystallinum (TAYBI et al., 2002), foi observado que o ABA e as citocininas exercem um forte efeito 
promotor e repressor, respectivamente, sobre a expressão do CAM em $A$. comosus. Constatou-se, ainda, que a mobilização de íons $\mathrm{Ca}^{2+}$ a partir do apoplasto representa uma importante etapa durante as vias de transdução de sinais que levam à indução do CAM nessa bromélia. Por fim, os dados obtidos também indicam a participação do NO como um mediador do sinal do ABA durante a regulação da expressão do CAM, sendo essa observação inédita não apenas para o abacaxizeiro, mas também para outras espécies vegetais.

Em conjunto, os resultados obtidos no presente estudo permitiram propor um esquema preliminar dos eventos de sinalização envolvidos na indução de $A$. comosus ao CAM em resposta ao estresse hídrico, o qual encontra-se representado na Figura 50.

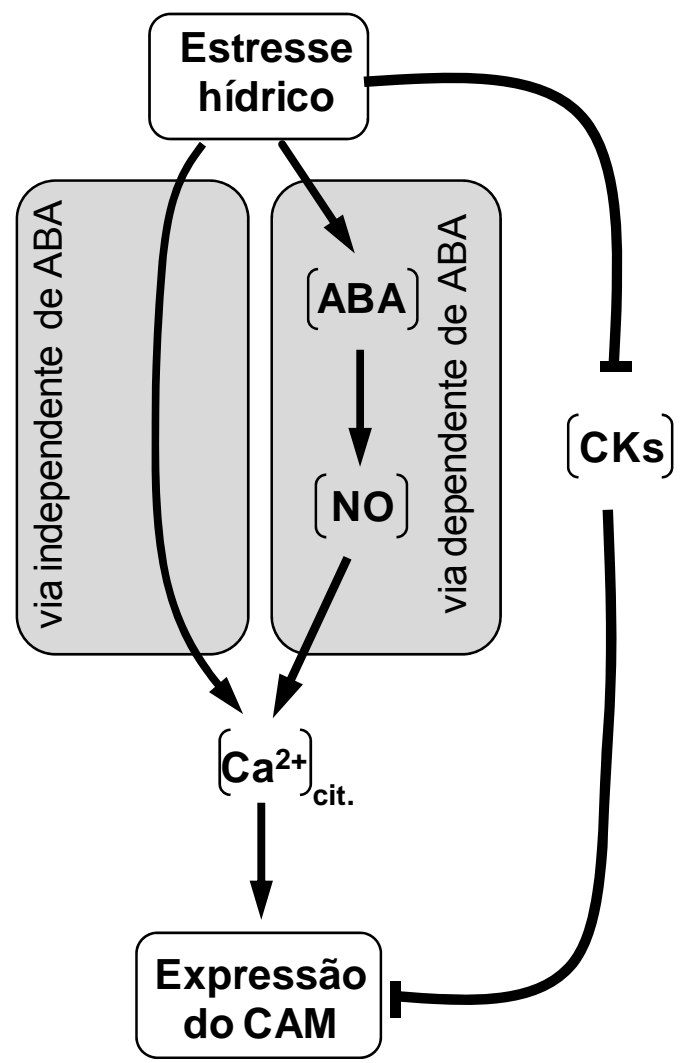

Figura 50: Esquema proposto para as vias de sinalização da indução do CAM em Ananas comosus. Setas indicam ativação e as barras inibição. CKs: citocininas. 


\section{CONCLUSÕES}

Em conclusão, o conjunto de resultados obtidos no desenvolvimento desta pesquisa indica que a expressão do CAM em abacaxizeiro ocorre de modo reversível e é controlada por uma complexa rede de interações entre fitormônios e mensageiros secundários.

De acordo com os dados obtidos, a sinalização da expressão do CAM nessa bromélia parece envolver duas vias distintas: a via dependente de $A B A$ e a via independente de ABA. A existência da via dependente de ácido abscísico foi evidenciada pelo efeito estimulatório do ABA exógeno sobre a indução do CAM em plantas mantidas na ausência de estresse hídrico e, também, pela existência de uma correlação positiva entre os teores endógenos desse hormônio e o grau de expressão do CAM em abacaxizeiro. Já a via independente de ABA foi demonstrada pela ocorrência da indução do CAM em resposta ao estresse hídrico mesmo quando o acúmulo de ABA foi completamente inibido.

Uma série de observações sugere que o óxido nítrico também participaria da via de sinalização do CAM em abacaxizeiro, atuando, provavelmente, como um mediador do sinal do ABA. As evidências que apontam o envolvimento do NO na sinalização desse evento fisiológico incluem a ocorrência de um incremento na expressão do CAM em plantas tratadas com esse radical livre e, também, a existência de uma forte correlação temporal entre o aumento na produção de NO e a indução da fotossíntese CAM nessa bromélia. Já a atuação do NO como um mediador do sinal do ácido abscísico encontra-se respaldada na constatação de que tratamentos com $A B A$ exógeno resultaram em uma maior produção de NO nos tecidos foliares de abacaxizeiro e, em contrapartida, a remoção do NO desses tecidos bloqueou completamente a indução do CAM em resposta à aplicação de ABA. 
As citocininas, por sua vez, atuariam como repressoras da transição de $\mathrm{C}_{3}$ para CAM em abacaxizeiro, já que a aplicação desse hormônio inibiu parcialmente a indução do CAM em resposta ao estresse hídrico e, além disso, houve uma correlação negativa entre os teores endógenos das quatro citocininas analisadas e o grau de expressão do CAM nessa bromélia. Em contrapartida, as auxinas e o etileno parecem não influenciar o tipo de comportamento fotossintético apresentado por $A$. comosus.

Por fim, os tratamentos com substâncias moduladoras da sinalização por $\mathrm{Ca}^{2+}$ citossólico demonstraram que o aumento na concentração citoplasmática desse íon representa uma etapa importante na indução de $A$. comosus ao CAM em resposta ao estresse hídrico, ABA ou NO. Dessa forma, na cascata de sinais que levam à indução do CAM, o $\mathrm{Ca}^{2+}$ citossólico representaria um ponto de convergência entre as vias de sinalização dependente e independente de ABA. 


\section{RESUMO}

A expressão do metabolismo ácido crassuláceo (CAM) nas plantas $\mathrm{C}_{3}$-CAM facultativas pode ser fortemente modulada por uma variedade de sinais ambientais e endógenos. Visto que plantas de abacaxizeiro (Ananas comosus, variedade Smooth Cayenne) podem apresentar comportamento fotossintético do tipo $\mathrm{C}_{3}$ ou CAM quando cultivadas in vitro, o presente trabalho buscou analisar a participação de quatro classes hormonais (ácido abscísico, citocininas, auxinas e etileno), do cálcio citossólico $\left(\mathrm{Ca}^{2+}{ }_{\text {cit. }}\right)$ e do óxido nítrico (NO) na regulação da expressão do CAM nessa bromélia. Para tanto, os teores endógenos desses sinalizadores foram quantificados durante a indução e a reversão do CAM em abacaxizeiro. Além disso, também foram realizadas análises do grau de expressão do CAM em plantas tratadas com esses compostos sinalizadores ou com seus inibidores de síntese, transporte ou percepção. Os dados obtidos evidenciaram uma correlação positiva entre os teores endógenos de ácido abscísico (ABA) e a expressão do CAM em abacaxizeiro, uma vez que a indução e a reversão do CAM foram acompanhadas de, respectivamente, aumentos e reduções no conteúdo foliar desse hormônio. Em consonância com esses resultados, o fornecimento de $A B A$ exógeno resultou na indução do CAM em plantas mantidas na ausência de estresse hídrico, indicando, portanto, um efeito estimulatório desse hormônio sobre a expressão do CAM em $A$. comosus. Entretanto, constatou-se que a inibição do acúmulo de ABA não afetou a indução do CAM em resposta ao estresse hídrico, sugerindo que a transição de $\mathrm{C}_{3}$ para CAM em abacaxizeiro pode ocorrer tanto por uma via de sinalização dependente de ABA quanto por uma via independente de ABA. De modo inverso, os dados indicaram que as citocininas atuariam como reguladoras negativas da expressão do CAM em abacaxizeiro, uma vez que a aplicação desse hormônio inibiu parcialmente a indução do CAM em resposta ao estresse hídrico e, além disso, o conteúdo endógeno das quatro citocininas analisadas foi inversamente proporcional ao grau de expressão do CAM nessa bromélia. As auxinas e o etileno, por sua vez, parecem não estar envolvidos na regulação dos processos de indução e de reversão do CAM em abacaxizeiro. Por outro lado, os dados obtidos indicaram, de forma inédita, um papel sinalizador positivo do NO sobre a expressão da fotossíntese CAM. Verificou-se, por exemplo, que a aplicação de NO exógeno promoveu um aumento considerável na expressão do CAM em plantas de abacaxizeiro e, de modo condizente, foi observado um incremento na produção desse radical livre durante a transição da fotossíntese $\mathrm{C}_{3}$ 
para CAM em resposta ao estresse hídrico. Além disso, foi interessante constatar que a elevação na síntese de NO nos tecidos foliares de abacaxizeiro ocorreu principalmente no parênquima clorofiliano, sendo este tecido um dos principais alvos das alterações metabólicas necessárias para o estabelecimento da fotossíntese CAM. Os resultados também sugerem que o NO atuaria como um mensageiro secundário do sinal do $A B A$ na indução do CAM, já que a produção desse radical livre aumentou consideravelmente nas plantas tratadas com $\mathrm{ABA}$ e, em paralelo, tratamentos com seqüestrador de NO bloquearam parcialmente a indução do CAM em resposta ao ABA. Por fim, os tratamentos com quelante ou ionóforo de cálcio evidenciaram que o aumento na concentração citoplasmática desse íon desempenha uma função crucial na regulação da indução de $A$. comosus ao CAM em resposta ao estresse hídrico. De acordo com os resultados, alterações na concentração $\mathrm{Ca}^{2+}$ citossólico parecem representar um ponto de convergência entre as vias de sinalização dependente e independente de ABA que levam à indução do CAM em abacaxizeiro. Em conjunto, os dados obtidos no presente trabalho indicam que o $\mathrm{ABA}$, ○ $\mathrm{NO}$ e $\circ \mathrm{Ca}^{2+}$ citossólico interagem durante os eventos que sinalização que resultam na transição de $C_{3}$ para CAM em abacaxizeiro, enquanto que as citocininas parecem reprimir a expressão da fotossíntese CAM. 


\section{ABSTRACT}

The Crassulacean acid metabolism (CAM) expression in $\mathrm{C}_{3}$-CAM facultative plants can be strongly modulated by a diversity of environmental and endogenous signals. Since pineapple (Ananas comosus, variety Smooth Cayenne) plants can perform either $\mathrm{C}_{3}$ or CAM photosynthesis when grown in vitro, this work attempted to investigate the involvement of four hormonal classes (abscisic acid, cytokinins, auxins and ethylene), cytosolic calcium $\left(\mathrm{Ca}^{2+}{ }_{\text {cit. }}\right)$ and nitric oxide (NO) on the regulation of CAM expression in this bromeliad. To achieve this, the levels of these signaling compounds were measured during the pineapple $\mathrm{C}_{3}$-to-CAM induction and the CAM-to- $\mathrm{C}_{3}$ reversion. Furthermore, the degree of CAM expression in plants treated with these compounds and their inhibitors of synthesis, transport or perception was also analyzed. The data obtained showed that the endogenous levels of $A B A$ were positively correlated with the degree of CAM expression in pineapple, since the $\mathrm{C}_{3}$-to-CAM transition and the CAM-to- $\mathrm{C}_{3}$ reversion in this bromeliad were preceded by, respectively, increases and decreases in the ABA leaf content. Consistent with these results; exogenously applied ABA increased the CAM expression in plants maintained in the absence of water stress, thus, indicating a stimulatory effect of this hormone on the A. comosus CAM expression. However, the inhibition of ABA accumulation did not affect the CAM induction by water stress, suggesting that the pineapple $\mathrm{C}_{3}$-to-CAM transition can occur via both $A B A$-dependent and $A B A$-independent signaling pathways. On the opposite, the data indicated that cytokinins act as negative regulators of CAM expression in pineapple, since the adding of this hormone partially inhibited the CAM induction by water stress and, additionally, the endogenous levels of the four cytokinins analyzed were inversely proportional to the degree of CAM expression in this bromeliad. Auxins and ethylene, conversely, seem not to be involved in the regulation of the $\mathrm{C}_{3}$-to-CAM transition and the CAM-to- $\mathrm{C}_{3}$ reversion in pineapple. On the other hand, the data obtained indicated, by the first time, a positive signaling role for the NO on the expression of CAM photosynthesis. For instance, it was observed that the exogenously applied NO increased the CAM expression in pineapple plants and, in agreement; there was an elevation in the production of this free radical during the water stress-induced $\mathrm{C}_{3}$-to-CAM transition. Additionally, the elevation of the NO synthesis in the pineapple leaf tissues occurred mainly in the chlorenchyma, which is the plant tissue responsible for most of the metabolic changes necessary to the CAM photosynthesis establishment. The results also suggested that the NO may act as a 
second messenger of the ABA signal in the pineapple CAM induction, since the production of this free radical in ABA-treated plants increased considerably and, in parallel, treatments with a NO scavenger partially blocked the ABA-induced $\mathrm{C}_{3}$-to-CAM transition. Finally, treatments with calcium chelator or ionophore indicated that the increase in the cytosolic concentration of this ion plays a crucial role in the regulation of the CAM induction by water stress in A. comosus. According to the results, changes in the concentration of $\mathrm{Ca}^{2+}$ cytosolic seem to represent a convergence point between the ABA-dependent and ABA-independent signaling cascade leading to $\mathrm{CAM}$ induction in pineapple. Taken together, the data obtained in the present work indicated that ABA, NO and cytosolic $\mathrm{Ca}^{2+}$ interact during the signaling events leading to the pineapple $\mathrm{C}_{3}-\mathrm{CAM}$ transition, while the cytokinins seem to repress the expression of CAM photosynthesis. 


\section{ANEXO I}

\section{PEPC}

Seqüência obtida:

GTTCAAGGAGAGGTCATTGAGCAGTCTTTTGGGGAAGAACGTCTTTGCTTTAGAACACTTCAGAGGTACACTGCTGCCACTCT TGAGCATGGTATGCGCCCTCCTACTTCCCCGAAGCCAGAATGGAGGGCAATCTTGGATGAGATCGCTGTTGTGGCCACTGAGG AATACCGGTCAGTTGTGTTCAAAGAGCCTCGTTTCGTTGAGTACTTCCGTTTGGTATGTTGCCAGTTCTAATGGTCTAGATTT TGAGTAGTTGTGTTAATACTGGTACTATAAACGCCTTTTTTTCGTTTTTTCTTGGAACACTTTGAACTGTTCTTTTCATATAT ACTTATCATAATTTTCATTTAAAACTACATAAATATTCACCAATAGAAAATTCGGAAATCTCAGTCAGCCCAAAGTTATACTT CTGTAATTTGACTCTTTGAAAATAGTAGTATGAGTATCCACTTGATTTCAGAACGATGAGCTTCGTCTTCTATGTTTGTAGGC TACACCTGAACTAGAATATGGCAGGATGAACATTGGCAGCCGACCATCAAAAAGGAAGCCCAGCGGAGGCATAGAGTCCCTCC GTGCAATCCCATGGATATTTGCGTGGACACAGGCAAGGTTTCACCTTCCCGTGTGGCTTGGCTTCGGTGCAGCATTCAAACAT ATATTGCGAAAGGACAGA

Seqüência codificante: $405 \mathrm{pb}$

Seqüência do intron: 277 pb

Seqüência total: $682 \mathrm{pb}$

Análise pelo programa BLAST(n):

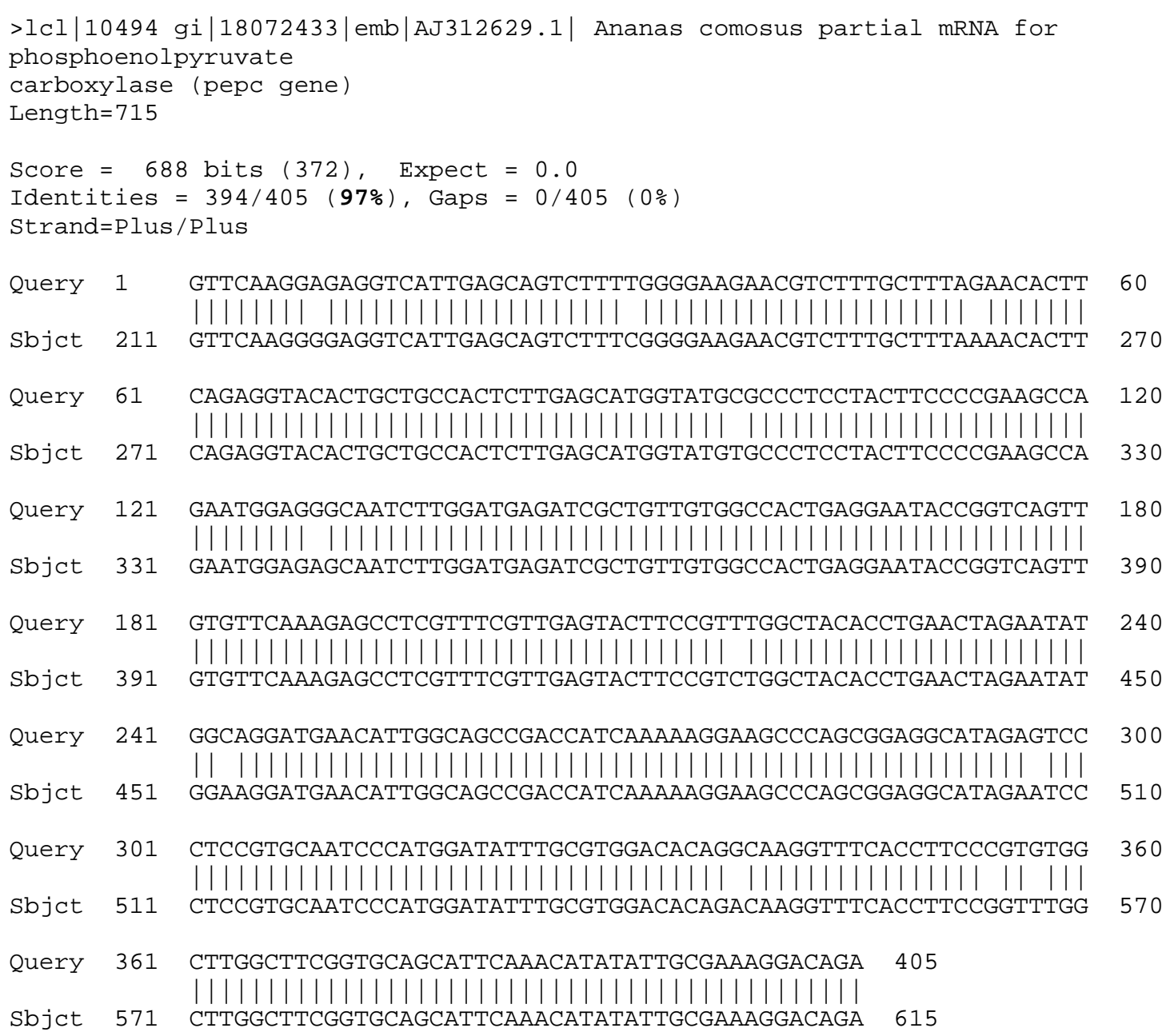




\title{
MDH
}

Seqüência obtida:

\begin{abstract}
TGCCCTTGAACAGTATGCAGCTAAAAATTGCAAGGTATCAAACGCTAGAGATTCAACCTATATTTCTCTGTTCTGTTTGAAAC TCAGTAAACTGAAAGAGTAAATGAACATCTTGGTTACTTCAGGACTTTGAAGCCATGGTTTTGTTGTTCTGATCTTGATCTGA TGTTTTGGCTGAAACTTTGAAACATAAACAAAATGTATTTCTTTACTCAGAATGAATCTAAATATGGCTTAGCTTTAGAACAT CAGCCCTAATCAACCAAAACTGGCTTGCAGAACATTTGATATCGATGTTGGTTTTCTATATTTAGCATCCTGATCTTTCTGAT AGACAACAAAATAATAGTTTGCTATGTTATTCTTTACATGATTTTCTACTGTTGCTAGTGTATTAGTACCTATTTTTTTTATT GCTAGTAATCAGTGTACACTTGCTGGTGCCTAATCTCTTTCAATGTTATGTCTGATTACCTGTAGGTGCTGGTTGTAGCAAAT CCTGCAAACACCAATGCATTGATCTTGAAAGAGTTTGCTCCATCCATCCCGGAGAAAAACATTACTTGCTTGAC
\end{abstract}

Seqüência codificante: 126 pb

Seqüência do intron: 446 pb

Seqüência total: $572 \mathrm{pb}$

Análise pelo programa BLAST(n):

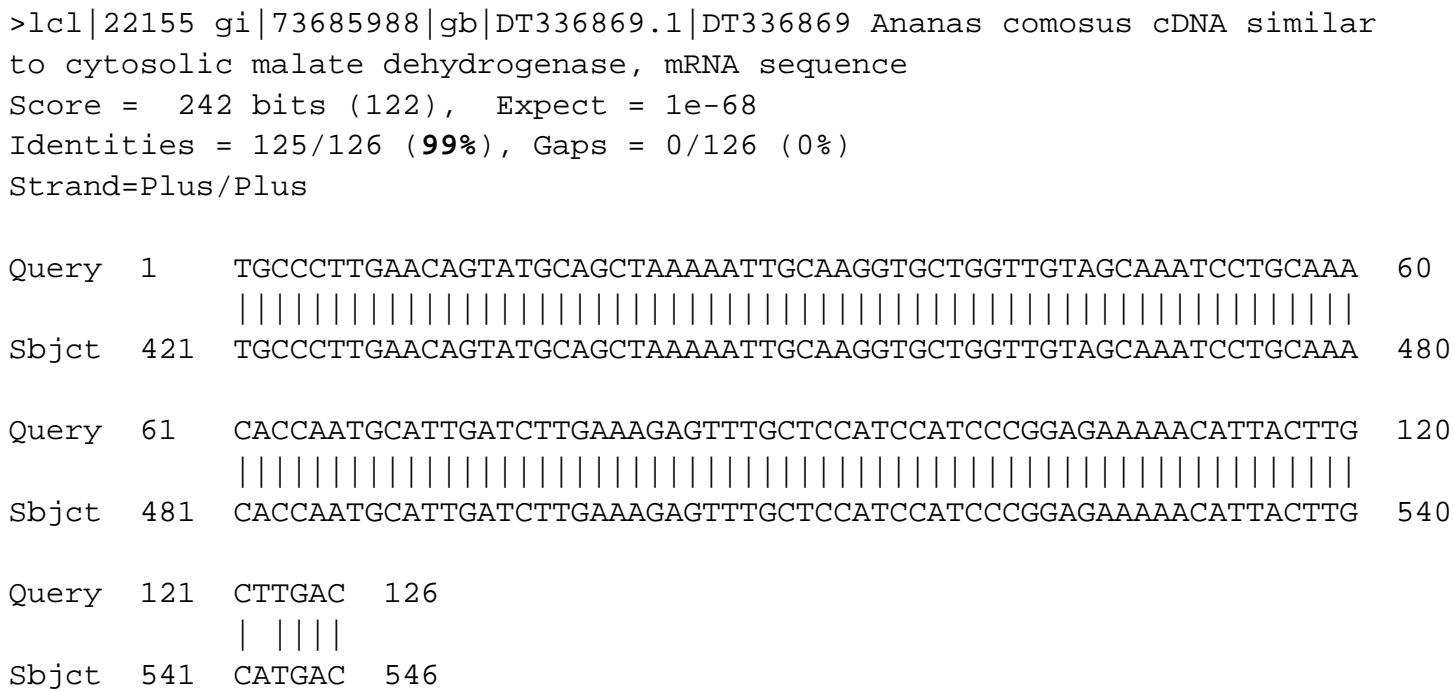




\section{PEPCK}

Seqüência obtida:

\section{ATTGAGGGTGGTTGTTATGCAAAATGCATTGACCTGTCCCGGGAAAAGGAGCCTGATATCTGGAATGCCATTAAATTTGGAAC TGGTGATTAAGTTGCTCTTTTGCTCTGTGTACCTCCTTTTGAATTAATTCCCTACTGGCTATCATTCAGATCCCTTTATGTAC TTTTTGGTTGTCATTCAGTGTTGGAGAATGTGGTTTTCGATGAGC}

Seqüência codificante: 112 pb

Seqüência do intron: 99 pb

Seqüência total: $211 \mathrm{pb}$

Análise pelo programa $\operatorname{BLAST}(\mathrm{n})$ :

>lcl|28189 gi|73684178|gb|DT335957.1|DT335957 Ananas comosus cDNA similar to Phosphoenolpyruvate carboxykinase, mRNA sequence Length $=998$

Score $=222$ bits $(112)$, Expect $=1 \mathrm{e}-62$

Identities $=112 / 112(\mathbf{1 0 0 \% )})$, Gaps $=\odot / 112(\odot \%)$

Strand=Plus/Plus

Query 1 ATTGAGgGTGGTTGTTATGCAAAATGCATTGACCTGTCCCGGGAAAAGGAGCCTGATATC

|||||||||||||||||||||||||||||||||||||||||||||||||||||||||||||

273 ATTGAGgGTGGTTGTTATGCAAAATGCATTGACCTGTCCCGgGAAAAGGAGCCTGATATC 332

Query 61 TgGAATGCCATTAAATTTGGAACTGTGTTGGAGAATGTGGTTTTCGATGAGC 112

sbjet 333 TGGAATGCCATTAAATTTGGAACTGTGTTGGAGAATGTGGTTTTCGATGAGC 38 


\section{REFERÊNCIAS BIBLIOGRÁFICAS}

AN, L.Z.; LIU, Y.H.; ZHANG, M.X.; CHEN, T.; WANG, X.L. Effects of nitric oxide on growth of maize seedling leaves in the presence or absence of ultraviolet-B radiation. Journal of Plant Physiology, v. 162, p. 317-326, 2005.

APELBAUM, A.; YANG, S.F. Biosynthesis of stress ethylene induced by water deficit. Plant Physiology, v. 68, p. 594-596, 1981.

ARASIMOWICZ, M.; FLORYSZAK-WIECZOREK, J. Nitric oxide as a bioactive signalling molecule in plant stress responses. Plant Science, v. 172, p. 876-887, 2007.

BANO, A.; HANSEN, H.; DORFFLING, K.; HAHN, H. Changes in the contents of free and conjugated abscisic acid, phaseic acid and citokinins in xylem sap of drought stressed sunflower plants. Phytochemistry, v. 37, p. 345-347, 1994.

BARKLA, B.J.; VERA-ESTRELLA, R.; MALDONADO-GAMA, M.; PANTOJA, O. Abscisic acid induction of vacuolar $\mathrm{H}^{+}$-ATPase activity in Mesembryanthemum crystallinum is developmentally regulated. Plant Physiology, v. 120, p. 811-819, 1999.

BARRS, H.D.; WEATHERLEY, P.E. A re-examination of relative turgidity technique for estimating water deficits in leaves. Australian Journal of Biological Sciences, v. 15, p. 413-\&, 1962.

BARTELS, D.; SUNKAR, R. Drought and salt tolerance in plants. Critical Reviews in Plant Sciences, v. 24, p. 23-58, 2005.

BASTIDE, B.; SIPES, D.; HANN, J.; TING, I.P. Effect of severe water stress on aspects of crassulacean acid metabolism in Xerosicyos. Plant Physiology, v. 103, p. 1089-1096, 1993.

BELIGNI, M.V.; LAMATTINA, L. Nitric oxide stimulates seed germination and de-etiolation, and inhibits hypocotyl elongation, three light-inducible responses in plants. Planta, v. 210, p. 215-221, 2000.

BELIGNI, M.V.; LAMATTINA, L. Nitric oxide: a non-traditional regulator of plant growth. Trends in Plant Science, v. 6, p. 508-509, 2001.

BELLAIRE, B.A.; CARMODY, J.; BRAUD, J.; GOSSETT, D.R.; BANKS, S.W.; LUCAS, M.C.; FOWLER, T.E. Involvement of abscisic acid-dependent and - independent pathways in the upregulation of antioxidant enzyme activity during $\mathrm{NaCl}$ stress in cotton callus tissue. Free Radical Research, v. 33, p. 531-545, 2000.

BENYEHOS, S.; ALONI, B. Effect of water stress on ethylene production by detached leaves of valencia orange (Citrus sinensis Osbeck). Plant Physiology, v. 53, p. 863-865, 1974.

BENZING, D.H. Bromeliaceae: profile of an adaptive radiation. Cambridge University Press. Cambridge. Cambridge, 724p, 2000.

BESSON-BARD, A.; COURTOIS, C.; GAUTHIER, A.; DAHAN, J.; DOBROWOLSKA, G.; JEANDROZ, S.; PUGIN, A.; WENDEHENNE, D. Nitric oxide in plants: production and cross-talk with $\mathrm{Ca}^{2+}$ signaling. Molecular Plant, v. 1, p. 218-228, 2008.

BETHKE, P.C.; LIBOUREL, I.G.L.; AOYAMA, N.; CHUNG, Y.Y.; STILL, D.W.; JONES, R.L. The Arabidopsis aleurone layer responds to nitric oxide, gibberellin, and abscisic acid and is sufficient and necessary for seed dormancy. Plant Physiology, v. 143, p. 1173-1188, 2007. 
BORLAND, A.M.; GRIFFITHS, H.; MAXWELL, C.; BROADMEADOW, M.S.J.; GRIFFITHS, N.M.; BARNES, J.D. On the ecophysiology of the Clusiaceae in Trinidad: Expression of CAM in Clusia minor $L$ during the transition from wet to dry season and characterization of 3 endemic species. New Phytologist, v. 122, p. 349-357, 1992.

BORLAND, A.M.; TECSI, L.I.; LEEGOOD, R.C.; WALKER, R.P. Inducibility of crassulacean acid metabolism (CAM) in Clusia species; physiological/biochemical characterisation and intercellular localization of carboxylation and decarboxylation processes in three species which exhibit different degrees of CAM. Planta, v. 205, p. 342-351, 1998.

BRIGHT, J.; DESIKAN, R.; HANCOCK, J.T.; WEIR, I.S.; NEILL, S.J. ABA-induced NO generation and stomatal closure in Arabidopsis are dependent on $\mathrm{H}_{2} \mathrm{O}_{2}$ synthesis. Plant Journal, v. 45, p. 113122, 2006.

BRULFERT, J.; GUCLU, S.; TAYBI, T.; PIERRE, J.N. Enzymatic responses to water stress in detached leaves of the CAM plant Kalanchoe blossfeldiana Poelln. Plant Physiology and Biochemistry, v. 31, p. 491-497, 1993.

BRULFERT, J.; KLUGE, M.; GUCLU, S.; QUEIROZ, O. Interaction of photoperiod and drought as CAM inducing factors in Kalanchoe blossfeldiana Poelln, Cv Tom Thumb. Journal of Plant Physiology, v. 133, p. 222-227, 1988.

BRULFERT, J.; RAVELOMANANA, D.; GUCLU, S.; KLUGE, M. Ecophysiological studies in Kalanchoe porphyrocalyx (Baker) and $K$. miniata (Hils et Bojer), two species performing highly flexible CAM. Photosynthesis Research, v. 49, p. 29-36, 1996.

CHEN, K.H.; MILLER, A.N.; PATTERSON, G.W.; COHEN, J.D. A rapid and simple procedure for purification of indole-3-acetic-acid prior to GC-SIM-MS analysis. Plant Physiology, v. 86, p. 822-825, 1988.

CHEN, K.M.; GONG, H.J.; CHEN, G.C.; ZHANG, C.L. ACC and MACC biosynthesis and ethylene production in water-stressed spring wheat. Acta Botanica Sinica, v. 44, p. 775-781, 2002.

CHOI, J.; HWANG, I. Cytokinin: Perception, signal transduction, and role in plant growth and development. Journal of Plant Biology, v. 50, p. 98-108, 2007.

CHOLLET, R.; VIDAL, J.; OLEARY, M.H. Phosphoenolpyruvate carboxylase: A ubiquitous, highly regulated enzyme in plants. Annual Review of Plant Physiology and Plant Molecular Biology, v. 47, p. 273-298, 1996.

CHRISTOPHER, J.T.; HOLTUM, J.A.M. Patterns of carbon partitioning in leaves of Crassulacean acid metabolism species during deacidification. Plant Physiology, v. 112, p. 393-399, 1996.

CHU, C.; DAI, Z.Y.; KU, M.S.B.; EDWARDS, G.E. Induction of crassulacean acid metabolism in the facultative halophyte Mesembryanthemum crystallinum by abscisic acid. Plant Physiology, v. 93, p. 1253-1260, 1990.

CONTI, S.; SMIRNOFF, N. Rapid triggering of malate accumulation in the $\mathrm{C}_{3} / \mathrm{CAM}$ intermediate plant Sedum telephium - Relationship with water status and phosphoenolpyruvate carboxylase. Journal of Experimental Botany, v. 45, p. 1613-1621, 1994.

CRAWFORD, N.M. Mechanisms for nitric oxide synthesis in plants. Journal of Experimental Botany, v. 57, p. $471-478,2006$. 
CRAYN, D.M.; WINTER, K.; SMITH, J.A.C. Multiple origins of crassulacean acid metabolism and the epiphytic habit in the Neotropical family Bromeliaceae. Proceedings of the National Academy of Sciences of the United States of America, v. 101, p. 3703-3708, 2004.

CUEVAS, I.C.; PODESTA, F.E. Purification and physical and kinetic characterization of an NAD ${ }^{+}$ dependent malate dehydrogenase from leaves of pineapple (Ananas comosus). Physiologia Plantarum, v. 108, p. 240-248, 2000.

CUSHMAN, J.C. Crassulacean acid metabolism. A plastic photosynthetic adaptation to arid environments. Plant Physiology, v. 127, p. 1439-1448, 2001.

CUSHMAN, J.C.; BOHNERT, H.J. Crassulacean acid metabolism: Molecular genetics. Annual Review of Plant Physiology and Plant Molecular Biology, v. 50, p. 305-332, 1999.

CUSHMAN, J.C.; BOHNERT, H.J. Molecular genetics of Crassulacean acid metabolism. Plant Physiology, v. 113, p. 667-676, 1997.

CUSHMAN, J.C.; BORLAND, A.M. Induction of Crassulacean acid metabolism by water limitation. Plant Cell and Environment, v. 25, p. 295-310, 2002.

CUSHMAN, J.C.; TILLETT, R.L.; WOOD, J.A.; BRANCO, J.M.; SCHLAUCH, K.A. Large-scale mRNA expression profiling in the common ice plant, Mesembryanthemum crystallinum, performing $\mathrm{C}_{3}$ photosynthesis and Crassulacean acid metabolism (CAM). Journal of Experimental Botany, v. 59 , p. $1875-1894,2008$.

DAI, Z.; KU, M.S.B.; ZHANG, D.Z.; EDWARDS, G.E. Effects of growth regulators on the induction of crassulacean acid metabolism in the facultative halophyte Mesembryanthemum crystallinum $\mathrm{L}$. Planta, v. 192, p. 287-294, 1994.

DANIEL, P.P.; WOODWARD, F.I.; BRYANT, J.A.; ETHERINGTON, J.R. Nocturnal accumulation of acid in leaves of wall pennywort (Umbilicus rupestris) following exposure to water stress. Annals of Botany, v. 55, p. 217-223, 1985.

DESIKAN, R.; CHEUNG, M.K.; BRIGHT, J.; HENSON, D.; HANCOCK, J.T.; NEILL, S.J. ABA, hydrogen peroxide and nitric oxide signalling in stomatal guard cells. Journal of Experimental Botany, v. 55, p. 205-212, 2004.

DESIKAN, R.; GRIFFITHS, R.; HANCOCK, J.; NEILL, S. A new role for an old enzyme: Nitrate reductase-mediated nitric oxide generation is required for abscisic acid-induced stomatal closure in Arabidopsis thaliana. Proceedings of the National Academy of Sciences of the United States of America, v. 99, p. 16314-16318, 2002.

DITTRICH, P.; CAMPBELL, W.H.; BLACK, C.C. Phosphoenolpyruvate carboxykinase in plants exhibiting Crassulacean acid metabolism. Plant Physiology, v. 52, p. 357-361, 1973.

DODD, A.N.; BORLAND, A.M.; HASLAM, R.P.; GRIFFITHS, H.; MAXWELL, K. Crassulacean acid metabolism: plastic, fantastic. Journal of Experimental Botany, v. 53, p. 569-580, 2002.

DODD, A.N.; LOVE, J.; WEBB, A.A.R. The plant clock shows its metal: circadian regulation of cytosolic free $\mathrm{Ca}^{2+}$. Trends in Plant Science, v. 10, p. 15-21, 2005.

DRENNAN, P.M.; NOBEL, P.S. Responses of CAM species to increasing atmospheric CO2 concentrations. Plant Cell and Environment, v. 23, p. 767-781, 2000. 
DURNER, J.; WENDEHENNE, D.; KLESSIG, D.F. Defense gene induction in tobacco by nitric oxide, cyclic GMP, and cyclic ADP-ribose. Proceedings of the National Academy of Sciences of the United States of America, v. 95, p. 10328-10333, 1998.

EDERLI, L.; MORETTINI, R.; BORGOGNI, A.; WASTERNACK, C.; MIERSCH, O.; REALE, L.; FERRANTI, F.; TOSTI, N.; PASQUALINI, S. Interaction between nitric oxide and ethylene in the induction of alternative oxidase in ozone-treated tobacco plants. Plant Physiology, v. 142, p. 595-608, 2006.

EKLUND, L.; CIENCIALA, E.; HALLGREN, J.E. No relation between drought stress and ethylene production in Norway spruce. Physiologia Plantarum, v. 86, p. 297-300, 1992.

ELBELTAG, A.S.; HALL, M.A. Effect of water stress upon endogenous ethylene levels in Vicia faba. New Phytologist, v. 73, p. 47-60, 1974.

FEELISCH, M. The use of nitric oxide donors in pharmacological studies. Naunyn-Schmiedebergs Archives of Pharmacology, v. 358, p. 113-122, 1998.

FLORYSZAK-WIECZOREK, J.; MILCZAREK, G.; ARASIMOWICZ, M.; CISZEWSKI, A. Do nitric oxide donors mimic endogenous NO-related response in plants? Planta, v. 224, p. 1363-1372, 2006.

FORSTHOEFEL, N.R.; CUSHMAN, M.A.F.; CUSHMAN, J.C. Posttranscriptional and posttranslational control of enolase expression in the facultative Crassulacean acid metabolism plant Mesembryanthemum crystallinum L. Plant Physiology, v. 108, p. 1185-1195, 1995a.

FORSTHOEFEL, N.R.; VERNON, D.M.; CUSHMAN, J.C. A salinity-induced gene from the halophyte $M$. crystallinum encodes a glycolytic enzyme, cofactor-independent phosphoglyceromutase. Plant Molecular Biology, v. 29, p. 213-226, 1995b.

FRANCO, A.C.; BALL, E.; LUTTGE, U. Differential effects of drought and light levels on accumulation of citric and malic acids during CAM in Clusia. Plant Cell and Environment, v. 15, p. 821-829, 1992.

FULTON, T.M.; CHUNWONGSE, J.; TANKSLEY, S.D. Microprep protocol for extraction of DNA from tomato and other herbaceous plants. Plant Molecular Biology Reporter, v. 13, p. 207-209, 1995.

GAMBLE, P.E.; MULLET, J.E. Inhibition of carotenoid accumulation and abscisic acid biosynthesis in fluridone-treated dark grown barley. European Journal of Biochemistry, v. 160, p. 117-121, 1986.

GARCIA-MATA, C.; LAMATTINA, L. Abscisic acid, nitric oxide and stomatal closure - is nitrate reductase one of the missing links? Trends in Plant Science, v. 8, p. 20-26, 2003.

GARCIA-MATA, C.; LAMATTINA, L. Nitric oxide and abscisic acid cross talk in guard cells. Plant Physiology, v. 128, p. 790-792, 2002.

GARCIA-MATA, C.; LAMATTINA, L. Nitric oxide induces stomatal closure and enhances the adaptive plant responses against drought stress. Plant Physiology, v. 126, p. 1196-1204, 2001.

GIBA, Z.; GRUBISIC, D.; TODOROVIC, S.; SAJC, L.; STOJAKOVIC, D.; KONJEVIC, R. Effect of nitric oxide - releasing compounds on phytochrome - controlled germination of Empress tree seeds. Plant Growth Regulation, v. 26, p. 175-181, 1998. 
GOMES, M.M.A.; LAGOA, A.; MACHADO, E.C.; MEDINA, C.L. Abscisic acid and indole-3-acetic acid contents in orange trees infected by Xylella fastidiosa and submitted to cycles of water stress. Plant Growth Regulation, v. 39, p. 263-270, 2003.

GOSTI, F.; BERTAUCHE, N.; VARTANIAN, N.; GIRAUDAT, J. Abscisic acid-dependent and abscisic acid-independent regulation of gene expression by progressive drought in Arabidopsis thaliana. Molecular \& General Genetics, v. 246, p. 10-18, 1995.

GOULD, K.S.; LAMOTTE, O.; KLINGUER, A.; PUGIN, A.; WENDEHENNE, D. Nitric oxide production in tobacco leaf cells: a generalized stress response? Plant Cell and Environment, v. 26, p. 1851-1862, 2003.

GOUVEA, C.; SOUZA, J.F.; MAGALHAES, A.C.N.; MARTINS, I.S. NO-releasing substances that induce growth elongation in maize root segments. Plant Growth Regulation, v. 21, p. 183-187, 1997.

GRAVATT, D.A.; MARTIN, C.E. Comparative ecophysiology of 5 species of Sedum (Crassulaceae) under well-watered and drought-stressed conditions. Oecologia, v. 92, p. 532-541, 1992.

GRIFFITHS, H.; SMITH, J.A.C. Photosynthetic pathways in the Bromeliaceae of Trinidad - Relations between life-forms, habitat preference and the occurrence of CAM. Oecologia, v. 60, p. 176184, 1983.

GRUN, S.; LINDERMAYR, C.; SELL, S.; DURNER, J. Nitric oxide and gene regulation in plants. Journal of Experimental Botany, v. 57, p. 507-516, 2006.

GUO, F.Q.; OKAMOTO, M.; CRAWFORD, N.M. Identification of a plant nitric oxide synthase gene involved in hormonal signaling. Science, v. 302, p. 100-103, 2003.

GURALNICK, L.J.; KU, M.S.B.; EDWARDS, G.E.; STRAND, D.; HOCKEMA, B.; EARNEST, J. Induction of PEP carboxylase and Crassulacean acid metabolism by gibberellic acid in Mesembryanthemum crystallinum. Plant and Cell Physiology, v. 42, p. 236-239, 2001.

GURALNICK, L.J.; TING, I.P. Seasonal response to drought and rewatering in Portulacaria afra (L) Jacq. Oecologia, v. 70, p. 85-91, 1986.

HANAHAN, D. (1983). Studies on transformation of E. coli with plasmids. Journal of Molecular Biology 156, 557-580.

HAO, G.P.; XING, Y.; ZHANG, J.H. Role of nitric oxide dependence on nitric oxide synthase-like activity in the water stress signaling of maize seedling. Journal of Integrative Plant Biology, $\mathrm{v}$. 50, p. 435-442, 2008.

HARE, P.D.; CRESS, W.A.; VAN STADEN, J. The involvement of cytokinins in plant responses to environmental stress. Plant Growth Regulation, v. 23, p. 79-103, 1997.

HAVLOVA, M.; DOBREV, P.I.; MOTYKA, V.; STORCHOVA, H.; LIBUS, J.; DOBRA, J.; MALBECK, J.; GAUDINOVA, A.; VANKOVA, R. The role of cytokinins in responses to water deficit in tobacco plants over-expressing trans-zeatin O-glucosyltransferase gene under 35 S or SAG12 promoters. Plant Cell and Environment, v. 31, p. 341-353, 2008.

HE, J.M.; XU, H.; SHE, X.P.; SONG, X.G.; ZHAO, W.M. The role and the interrelationship of hydrogen peroxide and nitric oxide in the UV-B-induced stomatal closure in broad bean. Functional Plant Biology, v. 32, p. 237-247, 2005. 
HE, Y.K.; TANG, R.H.; HAO, Y.; STEVENS, R.D.; COOK, C.W.; AM, S.M.; JING, L.F.; YANG, Z.G.; CHEN, L.G.; GUO, F.Q.; FIORANI, F.; JACKSON, R.B.; CRAWFORD, N.M.; PEI, Z.M. Nitric oxide represses the Arabidopsis floral transition. Science, v. 305, p. 1968-1971, 2004.

HERPPICH, W.; HERPPICH, M.; VONWILLERT, D.J. The irreversible $\mathrm{C}_{3}$ to CAM shift in well-watered and salt-stressed plants of Mesembryanthemum crystallinum is under strict ontogenic control. Botanica Acta, v. 105, p. 34-40, 1992.

HERPPICH, W.B.; HERPPICH, M. Influence of leaf water content on the $\mathrm{C}_{3}$-CAM transition in Mesembryanthemum crystallinum. New Phytologist, v. 136, p. 425-432, 1997.

HERRERA, A.; FERNANDEZ, M.D.; TAISMA, M.A. Effects of drought on CAM and water relations in plants of Peperomia carnevalii. Annals of Botany, v. 86, p. 511-517, 2000.

HOFFMAN, N.E.; LIU, Y.; YANG, S.F. Changes in 1-(malonylamino)cyclopropane-1-carboxylic acid content in wilted wheat leaves in relation to their ethylene production-rates and 1aminocyclopropane-1-carboxylic acid content. Planta, v. 157, p. 518-523, 1983.

HOHORST, H.J. L-(-)-Malate, Determination with malic dehydrogenase and DPN. In: L-(-)-Malate, Determination with malic dehydrogenase and DPN. H.U. Bergmeyer, ed. New York: Academic Press, p. 328-332, 1965.

HOLTUM, J.A.M.; WINTER, K. Activity of enzymes of carbon metabolism during the induction of Crassulacean acid metabolism in Mesembryanthemum crystallinum L. Planta, v. 155, p. 8-16, 1982.

HU, X.Y.; NEILL, S.J.; CAI, W.M.; TANG, Z.C. Nitric oxide mediates elicitor-induced saponin synthesis in cell cultures of Panax ginseng. Functional Plant Biology, v. 30, p. 901-907, 2003.

HUANG, X.; KIEFER, E.; VON RAD, U.; ERNST, D.; FOISSNER, I.; DURNER, J. Nitric oxide burst and nitric oxide-dependent gene induction in plants. Plant Physiology and Biochemistry, $v$. 40, p. 625-631, 2002.

HUANG, X.; STETTMAIER, K.; MICHEL, C.; HUTZLER, P.; MUELLER, M.J.; DURNER, J. Nitric oxide is induced by wounding and influences jasmonic acid signaling in Arabidopsis thaliana. Planta, v. 218, p. 938-946, 2004.

HUFTON, C.A., BESFORD, R.T., WELLBURN, R.A. Effects of $\mathrm{NO}\left({ }^{+} \mathrm{NO}_{2}\right)$ pollution on growth, nitrate reductase activities and associated protein contents in glasshouse lettuce grown hydroponically in winter with $\mathrm{CO}_{2}$ enrichment. New Phytologist. 133, 495-501, 1996.

HUNG, K.T.; CHANG, C.J.; KAO, C.H. Paraquat toxicity is reduced by nitric oxide in rice leaves. Journal of Plant Physiology, v. 159, p. 159-166, 2002.

HURST, A.C.; GRAMS, T.E.E.; RATAJCZAK, R. Effects of salinity, high irradiance, ozone, and ethylene on mode of photosynthesis, oxidative stress and oxidative damage in the $\mathrm{C}_{3} / \mathrm{CAM}$ intermediate plant Mesembryanthemum crystallinum L. Plant Cell and Environment, v. 27, p. 187-197, 2004.

ISHITANI, M.; XIONG, L.M.; STEVENSON, B.; ZHU, J.K. Genetic analysis of osmotic and cold stress signal transduction in Arabidopsis: Interactions and convergence of abscisic acid-dependent and abscisic acid-independent pathways. Plant Cell, v. 9, p. 1935-1949, 1997.

KAISER, W.M.; PLANCHET, E. Nitric oxide production in plants. Facts and Fictions. Plant Signaling and Behavior, v. 1:2, p. 46-51, 2006. 
KIM, S.Y. Recent advances in ABA signaling. Journal of Plant Biology, v. 50, p. 117-121, 2007.

KLEPPER, L.A. Evolution of nitrogen oxide gases from herbicide treated plant tissues. WSSA Abstracts, 184, 70, 1975.

KLESSIG, D.F.; DURNER, J.; NOAD, R.; NAVARRE, D.A.; WENDEHENNE, D.; KUMAR, D.; ZHOU, J.M.; SHAH, J.; ZHANG, S.Q.; KACHROO, P.; TRIFA, Y.; PONTIER, D.; LAM, E.; SILVA, H. Nitric oxide and salicylic acid signaling in plant defense. Proceedings of the National Academy of Sciences of the United States of America, v. 97, p. 8849-8855, 2000.

KOLBERT, Z.; BARTHA, B.; ERDEI, L. Osmotic stress- and indole-3-butyric acid-induced NO generation are partially distinct processes in root growth and development in Pisum sativum. Physiologia Plantarum, v. 133, p. 406-416, 2008.

KOPYRA, M.; GWOZDZ, E.A. Nitric oxide stimulates seed germination and counteracts the inhibitory effect of heavy metals and salinity on root growth of Lupinus luteus. Plant Physiology and Biochemistry, v. 41, p. 1011-1017, 2003.

KOZLIK, P.; BAEHLER, M.; PUENTENER, C.; ZERBE, O.; BIGLER, L.; ALTORFER, H.R. Nnitrosylation potential of mono-N-desethylamiodarone at physiological $\mathrm{pH}$. Journal of Pharmaceutical and Biomedical Analysis, v. 34, p. 399-407, 2004.

KUIPER, D., SCHUIT, J., KUIPER, P.J.C. Actual cytokinin concentrations in plant tissues as an indicator for salt resistance in cereals. Plant Soil, v. 123, p. 243-250, 1990.

LAMATTINA, L.; GARCIA-MATA, C.; GRAZIANO, M.; PAGNUSSAT, G. Nitric oxide: The versatility of an extensive signal molecule. Annual Review of Plant Biology, v. 54, p. 109-136, 2003.

LAMOTTE, O.; COURTOIS, C.; BARNAVON, L.; PUGIN, A.; WENDEHENNE, D. Nitric oxide in plants: the biosynthesis and cell signalling properties of a fascinating molecule. Planta, v. 221, p. 1-4, 2005.

LAMOTTE, O.; GOULD, K.; LECOURIEUX, D.; SEQUEIRA-LEGRAND, A.; LEBRUN-GARCIA, A.; DURNER, J.; PUGIN, A.; WENDEHENNE, D. Analysis of nitric oxide signaling functions in tobacco cells challenged by the elicitor cryptogein. Plant Physiology, v. 135, p. 516-529, 2004.

LANTERI, M.L.; PAGNUSSAT, G.C.; LAMATTINA, L. Calcium and calcium-dependent protein kinases are involved in nitric oxide- and auxin-induced adventitious root formation in cucumber. Journal of Experimental Botany, v. 57, p. 1341-1351, 2006.

LEEGOOD, R.C.; WALKER, R.P. Regulation and roles of phosphoenolpyruvate carboxykinase in plants. Archives of Biochemistry and Biophysics, v. 414, p. 204-210, 2003.

LEI, Y.B.; YIN, C.Y.; LI, C.Y. Adaptive responses of Populus przewalskii to drought stress and SNP application. Acta Physiologiae Plantarum, v. 29, p. 519-526, 2007.

LESHEM, Y.Y.; HARAMATY, E. The characterization and contrasting effects of the nitric oxide free radical in vegetative stress and senescence of Pisum sativum Linn foliage. Journal of Plant Physiology, v. 148, p. 258-263, 1996.

LESHEM, Y.Y.; HARAMATY, E.; ILUZ, D.; MALIK, Z.; SOFER, Y.; ROITMAN, L.; LESHEM, Y. Effect of stress nitric oxide (NO): Interaction between chlorophyll fluorescence, galactolipid fluidity and lipoxygenase activity. Plant Physiology and Biochemistry, v. 35, p. 573-579, 1997. 
LESHEM, Y.Y.; PINCHASOV, Y. Non-invasive photoacoustic spectroscopic determination of relative endogenous nitric oxide and ethylene content stoichiometry during the ripening of strawberries Fragaria anannasa (Duch.) and avocados Persea americana (Mill.). Journal of Experimental Botany, v. 51, p. 1471-1473, 2000.

LESHEM, Y.Y.; WILLS, R.B.H.; KU, V.V.V. Evidence for the function of the free radical gas - nitric oxide (NO) - as an endogenous maturation and senescence regulating factor in higher plants. Plant Physiology and Biochemistry, v. 36, p. 825-833, 1998.

LI, B.; CHOLLET, R. Salt induction and the partial purification/characterization of phosphoenolpyruvate carboxylase protein-serine kinase from an inducible Crassulacean acid metabolism (CAM) plant, Mesembryanthemum crystallinum L. Archives of Biochemistry and Biophysics, v. 314 , p. 247-254, 1994.

LIBOUREL, I.G.L.; BETHKE, P.C.; DE MICHELE, R.; JONES, R.L. Nitric oxide gas stimulates germination of dormant Arabidopsis seeds: use of a flow-through apparatus for delivery of nitric oxide. Planta, v. 223, p. 813-820, 2006.

LIN, Q.; ABE, S.; NOSE, A.; SUNAMI, A.; KAWAMITSU, Y. Effects of high night temperature on crassulacean acid metabolism (CAM) photosynthesis of Kalanchoe pinnata and Ananas comosus. Plant Production Science, v. 9, p. 10-19, 2006.

LOPEZ-CARBONELL, M.; ALEGRE, L.; PASTOR, A.; PRINSEN, E.; VANONCKELEN, H. Variations in abscisic acid, indole-3-acetic acid and zeatin riboside concentrations in two Mediterranean shrubs subjected to water stress. Plant Growth Regulation, v. 20, p. 271-277, 1996.

LOPEZ-CARBONELL, M.; ALEGRE, L.; VANONCKELEN, H. Effects of water stress on cellular ultrastructure and on concentrations of endogenous abscisic acid and indole-3-acetic acid in Fatsia japonica leaves. Plant Growth Regulation, v. 14, p. 29-35, 1994.

LUTTGE, U. Ecophysiology of Crassulacean Acid Metabolism (CAM). Annals of Botany, v. 93, p. 629-652, 2004.

LUTTGE, U. Photosynthetic flexibility and ecophysiological plasticity: questions and lessons from Clusia, the only CAM tree, in the neotropics. New Phytologist, v. 171, p. 7-25, 2006.

LUTTGE, U.; STIMMEL, K.H.; SMITH, J.A.C.; GRIFFITHS, H. Comparative ecophysiology of CAM and $\mathrm{C}_{3}$ Bromeliads .2. Field-measurements of gas-exchange of CAM bromeliads in the humid tropics. Plant Cell and Environment, v. 9, p. 377-383, 1986.

MAGALHÃES, J.R., MONTE, D.C., DURZAN, D. Nitric oxide and ethylene emission in Arabidopsis thaliana. Physiology and Molecular Biology of Plants, v. 6, p. 117-127, 2000.

MAGALHÃES, J.R., PEDROSO, M.C., DURZAN, D. Nitric oxide, apoptosis and plant stress. Physiology and Molecular Biology of Plants, v. 5, p. 115-125, 1999.

MAGALHÃES, J.R., SILVA, F.L.I.M., SALGADO, I.; FERRARESE-FILHO, O.; ROCKEL, P.; KAISER, W.M. Nitric oxide produced by nitrate reductase in higher plants. In: MAGALHÃES, J.R.; SINGH, R.P. eds. Nitric oxide signaling in higher plants. Houston, Studium Press, p. 167-181, 2005.

MAGALHÃES, J.R., MODOLO, L.V.; SOUZA, S.R.; FRESCHI, L.; FRANÇA, M.G.C.; SILVA, F.L.I.M. Origem do óxido nítrico em plantas e seu papel como sinalizador de estresses. In: FERNANDES, M.S. ed. Nutrição mineral de plantas. Viçosa, Sociedade Brasileira de Ciência do Solo, p. 201-214, 2006. 
MAHOUACHI, J.; ARBONA, V.; GOMEZ-CADENAS, A. Hormonal changes in papaya seedlings subjected to progressive water stress and re-watering. Plant Growth Regulation, v. 53, p. 4351, 2007.

MARTIN, C.E. Physiological Ecology of the Bromeliaceae. Botanical Review, v. 60, p. 1-82, 1994.

MAXWELL, C.; GRIFFITHS, H.; BORLAND, A.M.; BROADMEADOW, M.S.J.; MCDAVID, C.R. Photoinhibitory responses of the epiphytic bromeliad Guzmania monostachia during the dry season in Trinidad maintain photochemical integrity under adverse conditions. Plant Cell and Environment, v. 15, p. 37-47, 1992.

MAXWELL, C.; GRIFFITHS, H.; BORLAND, A.M.; YOUNG, A.J.; BROADMEADOW, M.S.J.; FORDHAM, M.C. Short-term photosynthetic responses of the $\mathrm{C}_{3}$-CAM epiphyte Guzmania monostachia var monostachia to tropical seasonal transitions under field conditions. Australian Journal of Plant Physiology, v. 22, p. 771-781, 1995.

MAXWELL, C.; GRIFFITHS, H.; YOUNG, A.J. Photosynthetic acclimation to light regime and water stress by the $\mathrm{C}_{3}$-CAM epiphyte guzmania monostachia: gas-exchange characteristics, photochemical efficiency and the xanthophyll cycle. Functional Ecology, v. 8, p. 746-754, 1994.

MAXWELL, K. Resistance is useful: diurnal patterns of photosynthesis in $\mathrm{C}_{3}$ and crassulacean acid metabolism epiphytic bromeliads. Functional Plant Biology, v. 29, p. 679-687, 2002.

MAXWELL, K.; MARRISON, J.L.; LEECH, R.M.; GRIFFITHS, H.; HORTON, P. Chloroplast acclimation in leaves of Guzmania monostachia in response to high light. Plant Physiology, v. 121, p. 89-95, 1999.

MEDINA, E.; DELGADO, M.; TROUGHTON, J.H.; MEDINA, J.D. Physiological ecology of $\mathrm{CO}_{2}$ fixation in Bromeliaceae. Flora, v. 166, p. 137-152, 1977.

MEDINA, E.; ZIEGLER, H.; LUTTGE, U.; TRIMBORN, P.; FRANCISCO, M. Light conditions during growth as revealed by $\Delta^{13} \mathrm{C}$ values of leaves of primitive cultivars of Ananas comosus, an obligate CAM species. Functional Ecology, v. 8, p. 298-305, 1994.

MEDVEDEV, S.S. Calcium signaling system in plants. Russian Journal of Plant Physiology, v. 52, p. 249-270, 2005.

MISHINA, T.E.; LAMB, C.; ZEIER, J. Expression of a nitric oxide degrading enzyme induces a senescence programme in Arabidopsis. Plant Cell and Environment, v. 30, p. 39-52, 2007.

MOK, D.W.S.; MOK, M.C. Cytokinin metabolism and action. Annual Review of Plant Physiology and Plant Molecular Biology, v. 52, p. 89-118, 2001.

MORGAN, P.W.; DREW, M.C. Ethylene and plant responses to stress. Physiologia Plantarum, v. 100, p. 620-630, 1997.

MORGAN, P.W.; HE, C.J.; DEGREEF, J.A.; DEPROFT, M.P. Does water deficit stress promote ethylene synthesis by intact plants. Plant Physiology, v. 94, p. 1616-1624, 1990.

MURASHIGE, T.; SKOOG, F. A revised medium for rapid growth and bioassays with tobacco tissue cultures. Physiologia Plantarum, v. 15, p. 473-497, 1962.

NAMBARA, E.; MARION-POLL, A. Abscisic acid biosynthesis and catabolism. Annual Review of

Plant Biology, v. 56, p. 165-185, 2005. 
NAPOLI, C.; IGNARRO, L.J. Nitric oxide-releasing drugs. Annual Review of Pharmacology and Toxicology, v. 43, p. 97-123, 2003.

NAQVI, S.S.M. Plant hormones under stressful conditions. In Handbook of Plant Crop Stress, M. Pessarakli, ed. New York: Marcel Dekker, pp. 645-660, 1995.

NARAYANA, I.; LALONDE, S.; SAINI, H.S. Water stress-induced ethylene production in wheat: a fact or artifact. Plant Physiology, v. 96, p. 406-410, 1991.

NEALES, T.F.; SALE, P.J.M.; MEYER, C.P. Carbon dioxide assimilation by pineapple plants, Ananas comosus $(L)$ Merr. 2. Effects of variation of the day-night temperature regime. Australian Journal of Plant Physiology, v. 7, p. 375-385, 1980.

NEILL, S. Interactions between abscisic acid, hydrogen peroxide and nitric oxide mediate survival responses during water stress. New Phytologist, v. 175, p. 4-6, 2007.

NEILL, S.; BARROS, R.; BRIGHT, J.; DESIKAN, R.; HANCOCK, J.; HARRISON, J.; MORRIS, P.; RIBEIRO, D.; WILSON, I. Nitric oxide, stomatal closure, and abiotic stress. Journal of Experimental Botany, v. 59, p. 165-176, 2008.

NEILL, S.J.; DESIKAN, R.; CLARKE, A.; HURST, R.D.; HANCOCK, J.T. Hydrogen peroxide and nitric oxide as signalling molecules in plants. Journal of Experimental Botany, v. 53, p. 1237-1247, 2002.

NEILL, S.J.; DESIKAN, R.; HANCOCK, J.T. Nitric oxide signalling in plants. New Phytologist, v. 159, p. 11-35, 2003.

NIEVOLA, C.C.; KRAUS, J.E.; FRESCHI, L.; SOUZA, B.M.; MERCIER, H. Temperature determines the occurrence of CAM or $\mathrm{C}_{3}$ photosynthesis in pineapple plantlets grown in vitro. In Vitro Cellular \& Developmental Biology-Plant, v. 41, p. 832-837, 2005.

$\mathrm{OH}$, S.; MCCASLIN, P.P. The iron component of sodium nitroprusside blocks NMDA-induced glutamate accumulation and intracellular $\mathrm{Ca}^{2+}$ elevation. Neurochemical Research, v. 20, p. 779-784, 1995.

ORITANI, T.; KIYOTA, H. Biosynthesis and metabolism of abscisic acid and related compounds.

Natural Product Reports, v. 20, p. 414-425, 2003.

OROZCO-CARDENAS, M.L.; RYAN, C.A. Nitric oxide negatively modulates wound signaling in tomato plants. Plant Physiology, v. 130, p. 487-493, 2002.

OSMOND, C.B. Crassulacean acid metabolism - Curiosity in context. Annual Review of Plant Physiology and Plant Molecular Biology, v. 29, p. 379-414, 1978.

PAGNUSSAT, G.C.; LANTERI, M.L.; LAMATTINA, L. Nitric oxide and cyclic GMP are messengers in the indole acetic acid-induced adventitious rooting process. Plant Physiology, v. 132, p. 12411248, 2003.

PAGNUSSAT, G.C.; LANTERI, M.L.; LOMBARDO, M.C.; LAMATTINA, L. Nitric oxide mediates the indole acetic acid induction activation of a mitogen-activated protein kinase cascade involved in adventitious root development. Plant Physiology, v. 135, p. 279-286, 2004.

PAGNUSSAT, G.C.; SIMONTACCHI, M.; PUNTARULO, S.; LAMATTINA, L. Nitric oxide is required for root organogenesis. Plant Physiology, v. 129, p. 954-956, 2002. 
PARANI, M.; RUDRABHATLA, S.; MYERS, R.; WEIRICH, H.; SMITH, B.; LEAMAN, D.W.; GOLDMAN, S.L. Microarray analysis of nitric oxide responsive transcripts in Arabidopsis. Plant Biotechnology Journal, v. 2, p. 359-366, 2004.

PEDROSO, M.C.; MAGALHAES, J.R.; DURZAN, D. A nitric oxide burst precedes apoptosis in angiosperm and gymnosperm callus cells and foliar tissues. Journal of Experimental Botany, v. 51 , p. 1027-1036, 2000.

PERES, L.E.P., MERCIER, H., KERBAUY, G.B., SAFARI, G.R. (1997). Teores endógenos de AIA, citocininas e ABA em uma orquídea acaule e uma bromélia sem raiz, determinados por HPLC e ELISA. Revista Brasileira de Fisiologia Vegetal, v. 9, p. 169-176, 1997.

PETERS, W.; BECK, E.; PIEPENBROCK, M.; LENZ, B.; SCHMITT, J.M. Cytokinin as a negative effector of phosphoenolpyruvate carboxylase induction in Mesembryanthemum crystallinum. Journal of Plant Physiology, v. 151, p. 362-367, 1997.

PLANCHET, E.; KAISER, W.M. Nitric oxide (NO) detection by DAF fluorescence and chemiluminescence: a comparison using abiotic and biotic NO sources. Journal of Experimental Botany, v. 57, p. 3043-3055, 2006.

POPP, M.; JANETT, H.P.; LUTTGE, U.; MEDINA, E. Metabolite gradients and carbohydrate translocation in rosette leaves of CAM and $C_{3}$ bromeliads. New Phytologist, v. 157, p. 649656, 2003.

POSPISILOVA, J.; SYNKOVA, H.; RULCOVA, J. Cytokinins and water stress. Biologia Plantarum, v. 43, p. 321-328, 2000.

POSPISILOVA, J.; VAGNER, M.; MALBECK, J.; TRAVNIAKOVA, A.; BATKOVA, P. Interactions between abscisic acid and cytokinins during water stress and subsequent rehydration. Biologia Plantarum, v. 49, p. 533-540, 2005.

PURGATTO, E.; DO NASCIMENTO, J.R.O.; LAJOLO, F.M.; CORDENUNSI, B.R. The onset of starch degradation during banana ripening is concomitant to changes in the content of free and conjugated forms of indole-3-acetic acid. Journal of Plant Physiology, v. 159, p. 1105-1111, 2002.

REDDY, A.R.; SUNDAR, D.; GNANAM, A. Photosynthetic flexibility in Pedilanthus tithymaloides Poit, a CAM plant. Journal of Plant Physiology, v. 160, p. 75-80, 2003.

REDDY, A.S.N. Calcium: silver bullet in signaling. Plant Science, v. 160, p. 381-404, 2001.

RIBAUT, J.M.; PILET, P.E. Water stress and indol-3-acetic acid content of maize roots. Planta, v. 193, p. 502-507, 1994.

RIERA, M.; VALON, C.; FENZI, F.; GIRAUDAT, J.; LEUNG, J. The genetics of adaptive responses to drought stress: abscisic acid-dependent and abscisic acid-independent signalling components. Physiologia Plantarum, v. 123, p. 111-119, 2005.

RIOV, J.; HAUSMAN, R. Regulation of water stress-induced ethylene in citrus leaves. Israel Journal of Botany, v. 37, p. 83-91, 1988.

RUAN, H.H.; SHEN, W.B.; XU, L.L. Nitric oxide involved in the abscisic acid induced proline accumulation in wheat seedling leaves under salt stress. Acta Botanica Sinica, v. 46, p. 1307$1315,2004 a$. 
RUAN, H.H.; SHEN, W.B.; XU, L.L. Nitric oxide modulates the activities of plasma membrane $\mathrm{H}^{+}$ATPase and PPase in wheat seedling roots and promotes the salt tolerance against salt stress. Acta Botanica Sinica, v. 46, p. 415-422, 2004b.

RULCOVA, J.; POSPISILOVA, J. Effect of benzylaminopurine on rehydration of bean plants after water stress. Biologia Plantarum, v. 44, p. 75-81, 2001.

SAKAKIBARA, H. Cytokinins: Activity, biosynthesis, and translocation. Annual Review of Plant Biology, v. 57, p. 431-449, 2006.

SAMBROOK, J.; FRITSCH, E.F.; MANIATIS, T.E. Molecular cloning: a laboratory manual. $2^{\text {nd }}$ ed, Cold Spring Harbor Laboratory, Cold Spring Harbor, New York, 1989.

SANG, J.R.; JIANG, M.Y.; LIN, F.; XU, S.C.; ZHANG, A.; TAN, M.P. Nitric oxide reduces hydrogen peroxide accumulation involved in water stress-induced subcellular anti-oxidant defense in maize plants. Journal of Integrative Plant Biology, v. 50, p. 231-243, 2008a.

SANG, J.R.; ZHANG, A.; LIN, F.; TAN, M.P.; JIANG, M.Y. Cross-talk between calcium-calmodulin and nitric oxide in abscisic acid signaling in leaves of maize plants. Cell Research, v. 18, p. 577$588,2008 \mathrm{~b}$.

SAVOURE, A.; HUA, X.J.; BERTAUCHE, N.; VANMONTAGU, M.; VERBRUGGEN, N. Abscisic acidindependent and abscisic acid-dependent regulation of proline biosynthesis following cold and osmotic stresses in Arabidopsis thaliana. Molecular and General Genetics, v. 254, p. 104-109, 1997.

SAYED, O.H. Crassulacean acid metabolism 1975-2000, a check list. Photosynthetica, v. 39, p. 339352, 2001.

SCHERER, G.F.E.; HOLK, A. NO donors mimic and NO inhibitors inhibit cytokinin action in betalaineaccumulation in Amaranthus caudatus. Plant Growth Regulation, v. 32, p. 345-350, 2000 .

SCHMITT, J.M.; PIEPENBROCK, M. Regulation of phosphoenolpyruvate carboxylase and crassulacean acid metabolism induction in Mesembryanthemum crystallinum $L$ by cytokinin Modulation of leaf gene expression by roots. Plant Physiology, v. 99, p. 1664-1669, 1992.

SHE, X.P.; SONG, X.G.; HE, J.M. Role and relationship of nitric oxide and hydrogen peroxide in light/dark-regulated stomntal movement in Vicia faba. Acta Botanica Sinica, v. 46, p. 12921300, 2004.

SHI, Q.H.; DING, F.; WANG, X.F.; WEI, M. Exogenous nitric oxide protect cucumber roots against oxidative stress induced by salt stress. Plant Physiology and Biochemistry, v. 45, p. 542-550, 2007.

SHISHIDO, S.M.; DE OLIVEIRA, M.G. Photosensitivity of aqueous sodium nitroprusside solutions: Nitric oxide release versus cyanide toxicity. Progress in Reaction Kinetics and Mechanism, v. 26, p. $239-261,2001$.

SMITH, J.A.C.; GRIFFITHS, H.; LUTTGE, U.; CROOK, C.E.; GRIFFITHS, N.M.; STIMMEL, K.H. Comparative Ecophysiology of CAM and $\mathrm{C}_{3}$ Bromeliads. 4. Plant Water Relations. Plant Cell and Environment, v. 9, p. 395-410, 1986. 
TAYBI, T.; CUSHMAN, J.C. Abscisic acid signaling and protein synthesis requirements for phosphoenolpyruvate carboxylase transcript induction in the common ice plant. Journal of Plant Physiology, v. 159, p. 1235-1243, 2002.

TAYBI, T.; CUSHMAN, J.C. Signaling events leading to Crassulacean acid metabolism induction in the common ice plant. Plant Physiology, v. 121, p. 545-555, 1999.

TAYBI, T.; CUSHMAN, J.C.; BORLAND, A.M. Environmental, hormonal and circadian regulation of crassulacean acid metabolism expression. Functional Plant Biology, v. 29, p. 669-678, 2002.

TAYBI, T.; NIMMO, H.G.; BORLAND, A.M. Expression of phosphoenolpyruvate carboxylase and phosphoenolpyruvate carboxylase kinase genes. Implications for genotypic cavacity and phenotypic plasticity in the expression of crassulacean acid metabolism. Plant Physiology, v. 135, p. 587-598, 2004.

TAYBI, T.; SOTTA, B.; GEHRIG, H.; GUCLU, S.; KLUGE, M.; BRULFERT, J. Differential effects of abscisic acid on phosphoenolpyruvate carboxylase and CAM operation in Kalanchoe blossfeldiana. Botanica Acta, v. 108, p. 240-246, 1995.

THOMAS, J.C.; BOHNERT, H.J. Salt stress perception and plant growth regulators in the halophyte Mesembryanthemum crystallinum. Plant Physiology, v. 103, p. 1299-1304, 1993.

THOMAS, J.C.; MCELWAIN, E.F.; BOHNERT, H.J. Convergent induction of osmotic stressresponses. Abscisic acid, cytokinin, and the effects of $\mathrm{NaCl}$. Plant Physiology, v. 100, p. 416423, 1992.

TIAN, X.R.; LEI, Y.B. Physiological responses of wheat seedlings to drought and UV-B radiation. Effect of exogenous sodium nitroprusside application. Russian Journal of Plant Physiology, v. 54, p. 676-682, 2007.

TING, I.P. Crassulacean Acid Metabolism. Annual Review of Plant Physiology and Plant Molecular Biology, v. 36, p. 595-622, 1985.

TING, I.P. Effects of ABA on CAM in Portulacaria afra. Photosynthesis Research, v. 2, p. 39-48, 1981.

TUN, N.N.; HOLK, A.; SCHERER, G.F.E. Rapid increase of NO release in plant cell cultures induced by cytokinin. Febs Letters, v. 509, p. 174-176, 2001.

TUN, N.N.; LIVAJA, M.; KIEBER, J.J.; SCHERER, G.F.E. Zeatin-induced nitric oxide (NO) biosynthesis in Arabidopsis thaliana mutants of NO biosynthesis and of two-component signaling genes. New Phytologist, v. 178, p. 515-531, 2008.

TUN, N.N.; SANTA-CATARINA, C.; BEGUM, T.; SILVEIRA, V.; HANDRO, W.; FLOH, E.I.S.; SCHERER, G.F.E. Polyamines induce rapid biosynthesis of nitric oxide (NO) in Arabidopsis thaliana seedlings. Plant and Cell Physiology, v. 47, p. 346-354, 2006.

UCHIDA, A.; JAGENDORF, A.T.; HIBINO, T.; TAKABE, T. Effects of hydrogen peroxide and nitric oxide on both salt and heat stress tolerance in rice. Plant Science, v. 163, p. 515-523, 2002.

VAASEN, A.; BEGEROW, D.; HAMPP, R. Phosphoenolpyruvate carboxylase genes in $\mathrm{C}_{3}$, crassulacean acid metabolism (CAM) and $\mathrm{C}_{3} / \mathrm{CAM}$ intermediate species of the genus Clusia: rapid reversible $\mathrm{C}_{3} / \mathrm{CAM}$ switches are based on the $\mathrm{C}_{3}$ housekeeping gene. Plant Cell and Environment, v. 29, p. 2113-2123, 2006. 
VESELOV, D.S.; MUSTAFINA, A.R.; SABIRJANOVA, I.B.; AKHIYAROVA, G.R.; DEDOV, A.V.; VESELOV, S.U.; KUDOYAROVA, G.R. Effect of PEG-treatment on the leaf growth response and auxin content in shoots of wheat seedlings. Plant Growth Regulation, v. 38, p. 191-194, 2002.

VOMACKA, L.; POSPISILOVA, J. Rehydration of sugar beet plants after water stress: effect of cytokinins. Biologia Plantarum, v. 46, p. 57-62, 2003.

WANG, J.W.; WU, J.Y. Nitric oxide is involved in methyl jasmonate-induced defense responses and secondary metabolism activities of Taxus cells. Plant and Cell Physiology, v. 46, p. 923-930, 2005.

WELLBURN, A.R. Why are atmospheric oxides of nitrogen usually phytotoxic and not alternative fertilizers? New Phytologist, v. 115, p. 395-429, 1990.

WILDT, J., KLEY, D., ROCKEL, P., SEGSCHENEIDER, H.J. Emission of NO from several higher plant species. Journal of Geophysical Research, v. 102, p. 5919-5928, 1997.

WINTER, K.; ARANDA, J.; HOLTUM, J.A.M. Carbon isotope composition and water-use efficiency in plants with crassulacean acid metabolism. Functional Plant Biology, v. 32, p. 381-388, 2005.

WINTER, K.; GADEMANN, R. Daily changes in $\mathrm{CO}_{2}$ and water vapor exchange, chlorophyll fluorescence, and leaf water relations in the halophyte Mesembryanthemum crystallinum during the induction of Crassulacean acid metabolism in response to high $\mathrm{NaCl}$ salinity. Plant Physiology, v. 95, p. 768-776, 1991.

WINTER, K.; GARCIA, M.; HOLTUM, J.A.M. On the nature of facultative and constitutive CAM: environmental and developmental control of CAM expression during early growth of Clusia, Kalanchoe, and Opuntia. Journal of Experimental Botany, v. 59, p. 1829-1840, 2008.

XING, H.; TAN, L.L.; AN, L.H.; ZHAO, Z.G.; WANG, S.M.; ZHANG, C.L. Evidence for the involvement of nitric oxide and reactive oxygen species in osmotic stress tolerance of wheat seedlings: Inverse correlation between leaf abscisic acid accumulation and leaf water loss. Plant Growth Regulation, v. 42, p. 61-68, 2004.

XU, M.J.; DONG, J.F.; ZHU, M.Y. Nitric oxide mediates the fungal elicitor-induced hypericin production of Hypericum perforatum cell suspension cultures through a jasmonic-acid-dependent signal pathway. Plant Physiology, v. 139, p. 991-998, 2005.

YAMASAKI, H.; COHEN, M.F. NO signal at the crossroads: polyamine-induced nitric oxide synthesis in plants? Trends in Plant Science, v. 11, p. 522-524, 2006.

ZHANG, A.Y.; JIANG, M.Y.; ZHANG, J.H.; DING, H.D.; XU, S.C.; HU, X.L.; TAN, M.P. Nitric oxide induced by hydrogen peroxide mediates abscisic acid-induced activation of the mitogenactivated protein kinase cascade involved in antioxidant defense in maize leaves. New Phytologist, v. 175, p. 36-50, 2007.

ZHANG, Y.Y.; WANG, L.L.; LIU, Y.L.; ZHANG, Q.; WEI, Q.P.; ZHANG, W.H. Nitric oxide enhances salt tolerance in maize seedlings through increasing activities of proton-pump and $\mathrm{Na}+/ \mathrm{H}+$ antiport in the tonoplast. Planta, v. 224, p. 545-555, 2006.

ZHAO, D.Y.; TIAN, Q.Y.; LI, L.H.; ZHANG, W.H. Nitric oxide is involved in nitrate-induced inhibition of root elongation in Zea mays. Annals of Botany, v. 100, p. 497-503, 2007. 
ZHAO, L.Q.; ZHANG, F.; GUO, J.K.; YANG, Y.L.; LI, B.B.; ZHANG, L.X. Nitric oxide functions as a signal in salt resistance in the calluses from two ecotypes of reed. Plant Physiology, v. 134, p. 849-857, 2004.

ZHAO, Z.G.; CHEN, G.C.; ZHANG, C.L. Interaction between reactive oxygen species and nitric oxide in drought-induced abscisic acid synthesis in root tips of wheat seedlings. Australian Journal of Plant Physiology, v. 28, p. 1055-1061, 2001.

ZHOU, B.Y.; GUO, Z.F.; XING, J.P.; HUANG, B.R. Nitric oxide is involved in abscisic acid-induced antioxidant activities in Stylosanthes guianensis. Journal of Experimental Botany, v. 56, p. 3223-3228, 2005.

ZHU, J.; GOLDSTEIN, G.; BARTHOLOMEW, D.P. Gas exchange and carbon isotope composition of Ananas comosus in response to elevated $\mathrm{CO}_{2}$ and temperature. Plant Cell and Environment, v. 22, p. 999-1007, 1999.

ZHU, L.H.; VAN DE PEPPEL, A.; LI, X.Y.; WELANDER, M. Changes of leaf water potential and endogenous cytokinins in young apple trees treated with or without paclobutrazol under drought conditions. Scientia Horticulturae, v. 99, p. 133-141, 2004.

ZOTZ, G.; WINTER, K. Short-term regulation of Crassulacean acid metabolism activity in a tropical hemiepiphyte, Clusia uvitana. Plant Physiology, v. 102, p. 835-841, 1993. 